\title{
Surface-Water Quality Assessment of the Clover Creek Basin, Pierce County, Washington, 1991-92
}

By Kathleen A. McCarthy

U.S. Geological Survey

Water-Resources Investigations Report 95-4181

Prepared in cooperation with

PIERCE COUNTY PUBLIC WORKS DEPARTMENT

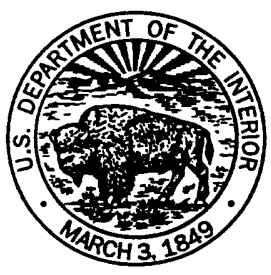

Tacoma, Washington 1996 


\section{U.S. DEPARTMENT OF THE INTERIOR}

BRUCE BABBITT, Secretary

U.S. GEOLOGICAL SURVEY

Gordon P. Eaton, Director

Any use of trade, product, or firm names is for descriptive purposes only and does not imply endorsement by the U.S. Government.

For additional information write to:

Copies of this report may be purchased from:

District Chief

U.S. Geological Survey

1201 Pacific Avenue - Suite 600

Tacoma, Washington 98402
U.S. Geological Survey

Branch of Information Services

Box 25286, MS 517

Denver. Colorado 80225-0286 


\section{CONTENTS}

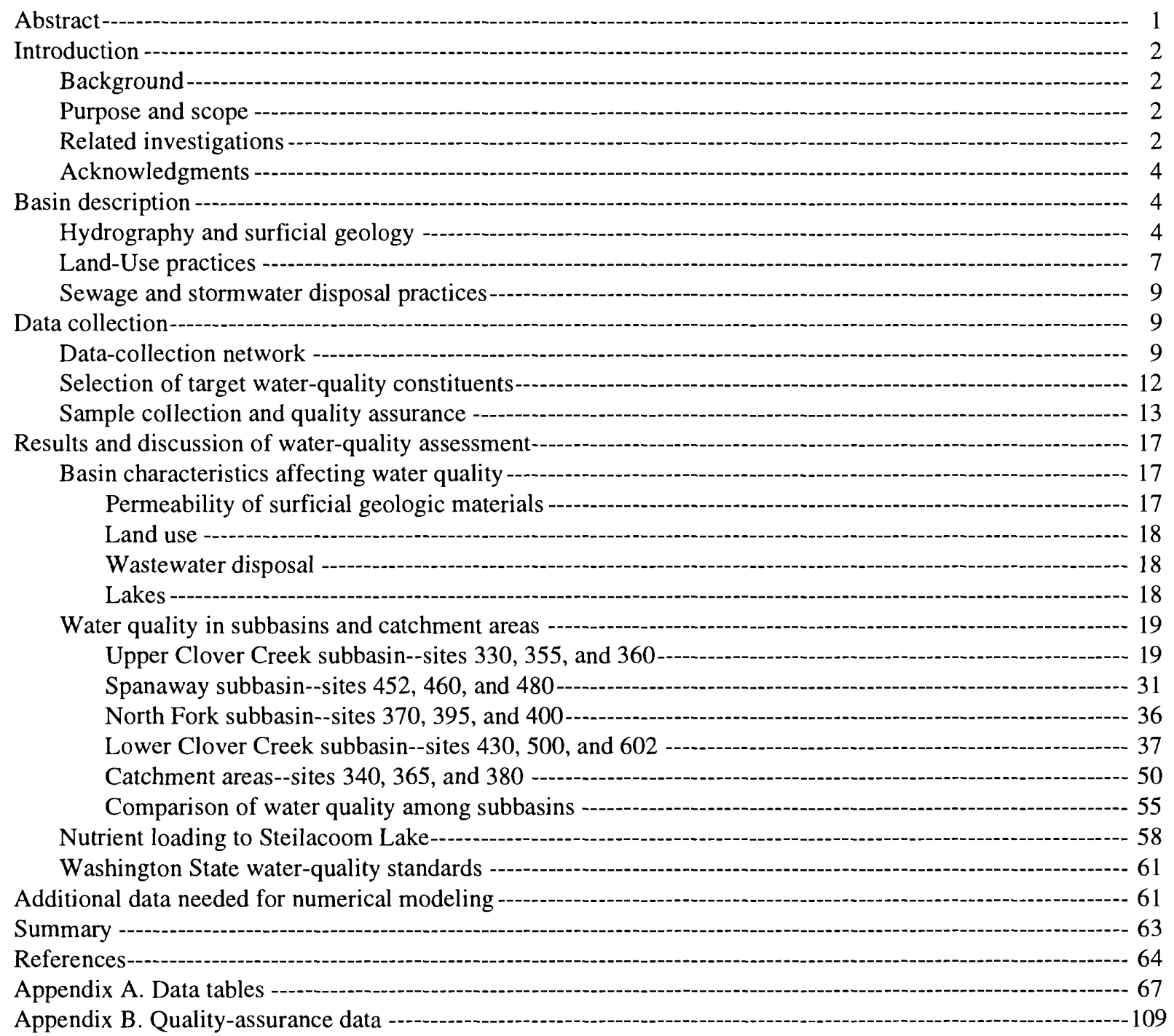

\section{FIGURES}

1-6. Maps showing:

1. Location of the Clover Creek Basin, Pierce County, Wash. -

2. Hydrography and drainage subbasins of the Clover Creek Basin, Pierce County, Wash. --------- 5

3. Surficial geology of the Clover Creek Basin, Pierce County, Wash. - - 6

4. Land development, 1991-92, in the Clover Creek Basin, Pierce County, Wash.---.------- 8

5. Sewage-collection system boundaries and locations of stormwater outfalls in the Clover Creek Basin, 1991-92, Pierce County, Wash. -

6. Data-collection sites in the Clover Creek Basin, Pierce County, Wash.-- 11 


\section{FIGURES--CONTINUED}

\section{7-38.Graphs showing:}

7. Instantaneous discharge, specific conductance, and concentrations of suspended sediment and dissolved chloride at three sites in the Upper Clover Creek subbasin, 1991-92-

8. Concentrations of dissolved nitrite plus nitrate, dissolved ammonia, and total ammonia plus organic nitrogen at three sites in the Upper Clover Creek subbasin, 1991-92 -

9. Concentrations of dissolved orthophosphate and total phosphorus at three sites in the Upper Clover Creek subbasin, 1991-92 --..-- 23

10. Temperature, $\mathrm{pH}$, fecal coliform, and fecal streptococci at three sites in the Upper Clover Creek subbasin, 1991-92 -- 24

11. Instantaneous discharge, specific conductance, and temperature at site 355, Upper Clover Creek subbasin, 1991-92 - 27

12. $\mathrm{pH}$ at site 355, Upper Clover Creek subbasin, August 1992

13. Dissolved oxygen, 5-day biochemical-oxygen demand, and ultimate biochemical-oxygen demand at two sites in the Upper Clover Creek subbasin, 1991-92-

14. Specific conductance and concentrations of total ammonia plus organic nitrogen, dissolved orthophosphate, total phosphate, and dissolved chloride at site 300 , 1962-64 and 1970-71, and at site 355, 1991-92, Upper Clover Creek subbasin

15. Instantaneous discharge, specific conductance, and concentrations of suspended sediment and dissolved chloride at three sites in the Spanaway subbasin, 1991-92 -.--...--..-- 32

16. Concentrations of dissolved nitrite plus nitrate, dissolved ammonia, and total ammonia plus organic nitrogen at three sites in the Spanaway subbasin, 1991-92 ---------------- 33

17. Concentrations of dissolved orthophosphate and total phosphorus at three sites in the Spanaway subbasin, 1991-92

\section{咩} 3 4 , 


\section{FIGURES--CONTINUED}

7-38.Graphs showing:

31. Specific conductance and concentrations of dissolved orthophosphate, total phosphate, and dissolved chloride at site 600,1962-65 and 1971-76, and at site 602, 1991-92, Lower Clover Creek subbasin-

32. Instantaneous discharge, specific conductance, and concentrations of suspended sediment and dissolved chloride at three catchment area sites in the Clover Creek subbasin, 1991-92

33. Concentrations of dissolved nitrite plus nitrate, dissolved ammonia, and total ammonia plus organic nitrogen at three catchment area sites in the Clover Creek subbasin, 1991-92 -

34. Concentrations of dissolved orthophosphate and total phosphorus at three catchment area sites in the Clover Creek Basin, 1991-92

35. Temperature, $\mathrm{pH}$, fecal coliform, and fecal streptococci at three catchment area sites in the Clover Creek Basin, 1991-92

36. Specific conductance and concentrations of suspended sediment and fecal coliform at all primary data-collection sites in the Clover Creek Basin, 1991-92

37. Concentrations of dissolved nitrite plus nitrate, dissolved ammonia, and total phosphorus at all primary data-collection sites in the Clover Creek Basin, 1991-92 -

38. Comparison of discharge and concentrations of total nitrogen at site 500, Lower Clover Creek subbasin, 1991-92

\section{TABLES}

1. Subbasin land-use categories (in percent of total area) in the Clover Creek Basin, 1991-92 ----------- 7

2. Data-collection sites in the Clover Creek Basin, 1991-92 --or 12

3. Water-quality constituents measured in the Clover Creek Basin, 1991-92-14

4. Observed range of total-recoverable metal concentrations in the Clover Creek Basin, 1991-92----.--- 25

5. Elemental composition of fine-grained (less than 63 micrometers in diameter) streambedsediment materials in the Clover Creek Basin, 1991-92 -.- 26

6. Estimated average monthly nitrogen and phosphorus loads at site 500 in the Clover Creek Basin, 1991-92 59

\section{CONVERSION FACTORS AND VERTICAL DATUM}

\begin{tabular}{rll}
\hline Multiply & By & To obtain \\
\hline acre & 0.4047 & hectare \\
square mile $\left(\mathrm{mi}^{2}\right)$ & 2.590 & square kilometer \\
cubic foot per second $\left(\mathrm{ft}^{3} / \mathrm{s}\right)$ & 0.02832 & cubic meter per second \\
\hline
\end{tabular}

Sea Level: In this report "sea level" refers to the National Geodetic Vertical Datum of 1929 (NGVD of 1929)--a geodetic datum derived from a general adjustment of the first-order level nets of both the United States and Canada, formerly called Sea Level Datum of 1929. 


\title{
SURFACE-WATER QUALITY ASSESSMENT OF THE CLOVER CREEK BASIN, PIERCE COUNTY, WASHINGTON, 1991-92
}

\author{
By Kathleen A. McCarthy
}

\begin{abstract}
Increasing urbanization in the 67-square-mile Clover Creek Basin has generated interest in the effects of land-use changes on local water quality. To investigate these effects, water-quality and streamflow data were collected from 19 surface-water sites in the basin over a 16-month period from January 1991 through April 1992. These data were used to understand the effects of surficial geology, land-use practices, and wastewater disposal practices on surface-water quality within the basin. The basin was divided into four drainage subbasins with dissimilar hydrogeologic, land-use, and water-quality characteristics.
\end{abstract}

In the Upper Clover Creek subbasin, the high permeability of surficial geologic materials promotes infiltration of precipitation to ground water and thus attenuates the response of streams to rainfall. Significant interaction occurs between surface and ground water in this subbasin, and nitrate concentrations and specific conductance values, similar to those found historically in local ground water, indicate that sources such as subsurface waste-disposal systems and fertilizers are affecting surface-water quality in this area.

In the Spanaway subbasin, the presence of Spanaway and Tule Lakes affects water quality, primarily because of the reduced velocity and long residence time of water in the lakes. Reduced water velocity and long residence times (1) cause settling of suspended materials, thereby reducing concentrations of suspended sediment and constituents that are bound to the sediment; (2) promote biological activity, which tends to trap nutrients in the lakes; and (3) allow dispersion to attenuate peaks in discharge and water-quality constituent concentrations.

In the North Fork subbasin, the low permeability of surficial geologic materials and areas of intensive land development inhibit infiltration of precipitation and thus promote surface runoff to streams. Surface pathways provide little attenuation of storm runoff and result in rapid increases in stream discharge in response to rainfall. Substantial increases in concentrations of constituents associated with surface wash off, for example, suspended sediment, ammonia, phosphorus, and fecal coliform, also were observed in this subbasin during rainfall.

In the Lower Clover Creek subbasin, which is the most downstream subbasin, stream-discharge and waterquality characteristics show the integrated effects of the entire basin. The data show that further characterization of local ground water and discharge from stormwater outfalls entering Clover Creek and its tributaries would be necessary to successfully apply a numerical water-quality model to the basin. 


\section{INTRODUCTION}

The Clover Creek Basin, located in central Pierce County, Wash., (fig. 1) is characterized by a variety of land-use categories. Land use within the basin currently ranges from rural areas of forest and grass to densely populated residential and commercial areas, but urbanized areas are expanding. Further land development within the basin will likely affect the characteristics of stormwater runoff and hence may alter the quality of receiving streams and lakes. This study was implemented to assess current water-quality conditions and improve understanding of the effects of various land-use practices on surface-water quality within the Clover Creek Basin.

\section{Background}

Numerous investigations over the past few decades have shown that stormwater runoff from developed areas commonly contains higher concentrations of such constituents as nitrogen and phosphorus compounds, metals, and bacteria than runoff from pristine landscapes (Omernik, 1976; Bedient, Harned, and Characklis, 1978; Griffin and others, 1978; Rimer, Nissen, and Reynolds, 1978; Helsel and others, 1979; Olivieri, 1980; U.S. Environmental Protection Agency, 1983; Blumberg and Bell, 1984; Driver and Tasker, 1988). In addition to influencing water quality, modifications in land use can alter the hydrologic response of a basin to rainfall, thereby affecting both the overall quantity and temporal distribution of stormwater runoff (Savini and Kammerer, 1961; Seaburn, 1969;

Anderson, 1970). Such changes in the quality and quantity of stormwater runoff may, in turn, alter the quality of receiving water bodies.

The U.S. Environmental Protection Agency's (USEPA) Nationwide Urban Runoff Program (U.S. Environmental Protection Agency, 1983) is the most geographically extensive study, to date, that focuses on the effects of urbanization on the quality of stormwater runoff. One of the conclusions of the USEPA study was that the quality of stormwater runoff, even among sites that drain areas of similar land use, varies considerably. This variation suggests that the factors controlling the quality of urban runoff are numerous, complex, and often site specific. Therefore, effective management and protection of water resources within the Clover Creek Basin requires an understanding of the factors that control local runoff characteristics.

\section{Purpose and Scope}

This report (1) describes the spatial and temporal water-quality characteristics of Clover Creek and its tributaries, (2) provides an understanding of the influence of land use and other basin characteristics on stormwater runoff and hence surface-water quality throughout the basin, and (3) identifies and discusses supplementary data that would be necessary to develop a robust numerical model of water quality in the basin.

The spatial and temporal water-quality characteristics of the Clover Creek Basin were investigated by sampling streams and precipitation over a 16-month period, from January 1991 through April 1992. Data were collected from 19 surface-water sites and 2 precipitation-collection sites in the basin. These data, along with historical data available for two sites within the basin provided an understanding of the influence of surficial geology, local land use, and wastewater disposal practices on surface-water quality within the basin. This understanding was then used to identify additional supplementary data that would be necessary for successful numerical modeling of water quality in the basin. This work was done in cooperation with the Surface Water Management Utility of the Pierce County Public Works Department.

\section{Related Investigations}

Previous investigations of the water resources of the Clover Creek Basin have contributed to an understanding of the basin hydrology and provided important historical information. These investigations include an assessment of ground- and surface-water quality (Littler, Aden, and Johnson, 1981), a study of the basin hydrogeology (Brown and Caldwell Consultants, 1985), and the development of a ground-water management program (Brown and Caldwell Consultants, 1991). Relevant findings from these investigations will be discussed later in this report.

Concurrent with the study reported here, an investigation of the rainfall-runoff characteristics of the Clover Creek Basin was done by Mastin (1996). A key focus of that study was to assess the influence of changes in land use on the hydrologic response of the basin. The information on stream discharge, land use, and surficial geology collected as part of Mastin's 1995 (1996) study was used in the current study as well. 


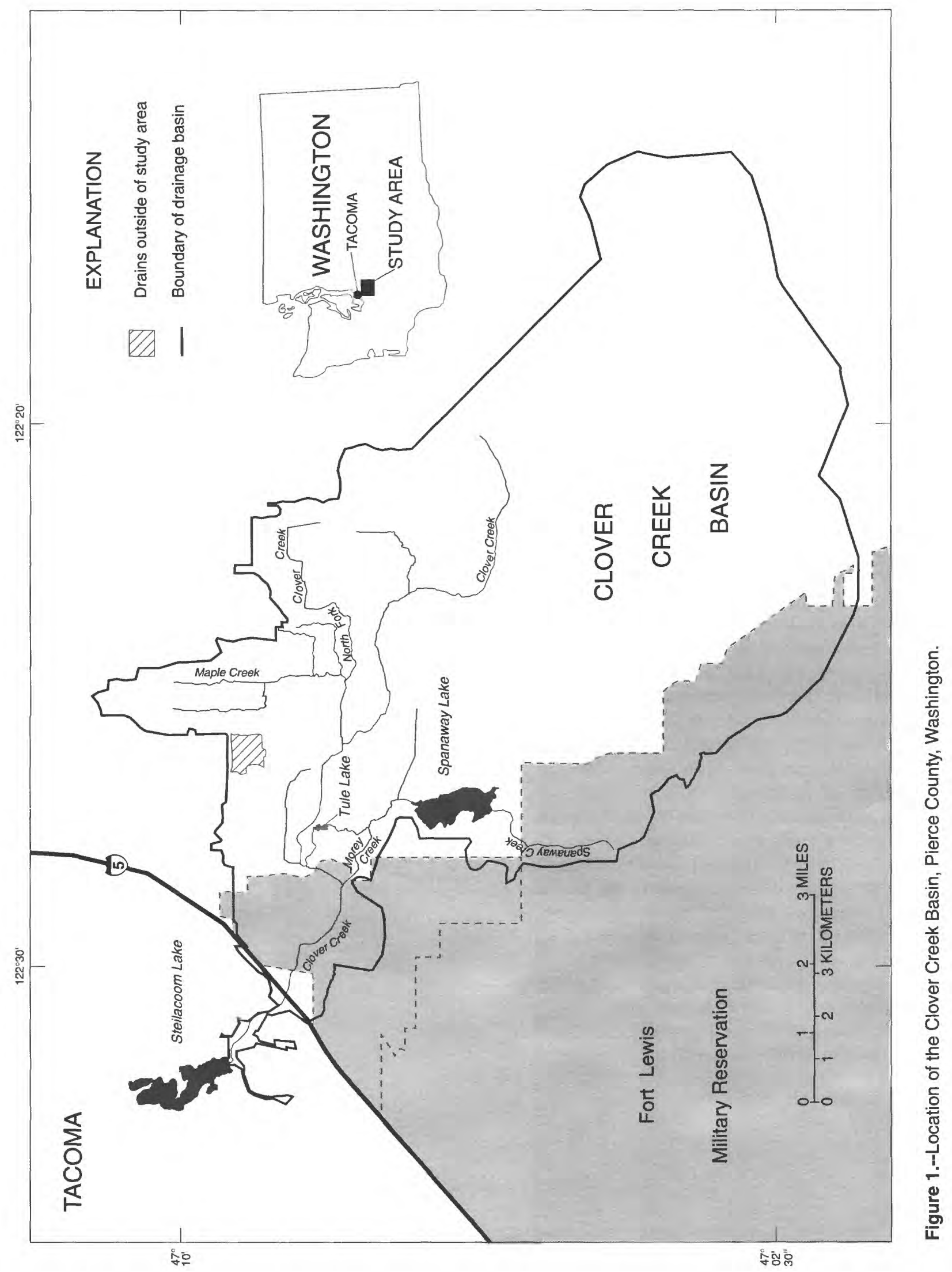




\section{Acknowledgments}

I wish to thank the employees of the Pierce County Surface Water Management Utility for their assistance in data-collection efforts. I also wish to express my appreciation to the citizens of Pierce County who helped collect data and who granted access to their property.

\section{BASIN DESCRIPTION}

The following sections describe the physical features, land-use characteristics, and wastewater disposal practices of the Clover Creek Basin. More detailed descriptions of the basin are provided by Littler, Aden, and Johnson (1981); Brown and Caldwell Consultants (1985); and Mastin (1996).

\section{Hydrography and Surficial Geology}

The Clover Creek Basin, which covers an area of approximately 67 square miles, can be divided into four major drainage subbasins defined by Clover Creek and its primary tributaries, the North Fork of Clover Creek and Spanaway Creek (fig. 2). The southeastern part of the basin, referred to as the Upper Clover Creek subbasin, covers approximately 35 square miles and is defined by the drainage of Clover Creek upstream of its confluence with the North Fork. The southwestern part of the basin is referred to as the Spanaway subbasin. This 19-squaremile subbasin includes Spanaway and Tule Lakes, the only appreciable lakes in the basin, and Morey Creek, a distributary from Spanaway Creek. Both the Upper Clover Creek and Spanaway subbasins are underlain primarily with coarse glacial outwash material known as the Steilacoom gravels (fig. 3). This material is highly permeable and thus has a high infiltration capacity. Because this material allows water to infiltrate so readily into the subsurface, these two subbasins are characterized by few surface drainage channels, and subsurface flow is predominant. Therefore, the upstream boundaries shown for these two subbasins (fig. 2) are those defined by Mastin (1996) and are based on the ground-water flow system rather than on surface features.
The North Fork subbasin, approximately 6 square miles in extent, is located in the northeastern part of the basin and is drained by the North Fork of Clover Creek. The surficial geology of this subbasin is dominated by glacial tills (fig. 3). A layer of lodgement till, or "hardpan," extends over most of this area, sometimes present at a depth of several feet. In contrast to the Steilacoom gravels, this layer is highly compacted and thus characterized by low permeability. As a result, infiltration and vertical flow of water through this material are limited, and therefore the North Fork subbasin has a larger number of surface drainage channels than the more permeable Upper Clover Creek and Spanaway subbasins. Another important hydrologic characteristic that distinguishes the North Fork subbasin from the rest of the basin is the ephemeral nature of surface-water flow in the area. During the summer months, flow ceases in the North Fork of Clover Creek and its tributaries.

The Upper Clover Creek, Spanaway, and North Fork subbasins drain into the Lower Clover Creek subbasin, a 7-square-mile area in the northwestern part of the basin. The Lower Clover Creek subbasin thus integrates all surface-water flow within the basin. Although the subbasin is underlain by the highly permeable Steilacoom gravels (fig. 3), parts of stream channels have been lined with impervious material to minimize seepage into the subsurface. These channel modifications, coupled with impervious surfaces such as rooftops, roadways, and parking lots associated with commercial and high-density residential development, reduce infiltration and thus modify the hydrologic response of the subbasin. All surface-water discharge from the Clover Creek Basin drains from the Lower Clover Creek subbasin into Steilacoom Lake. 


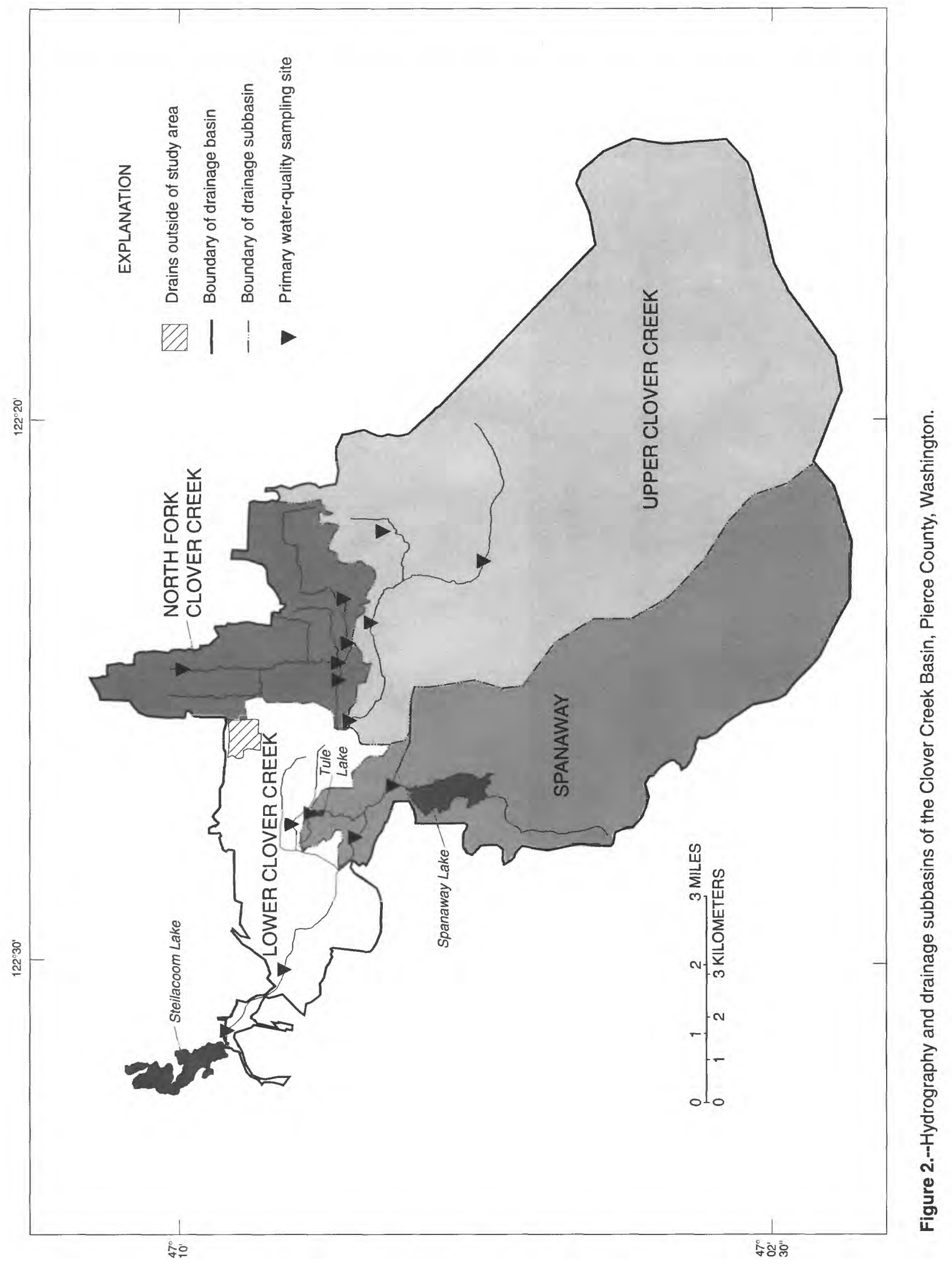




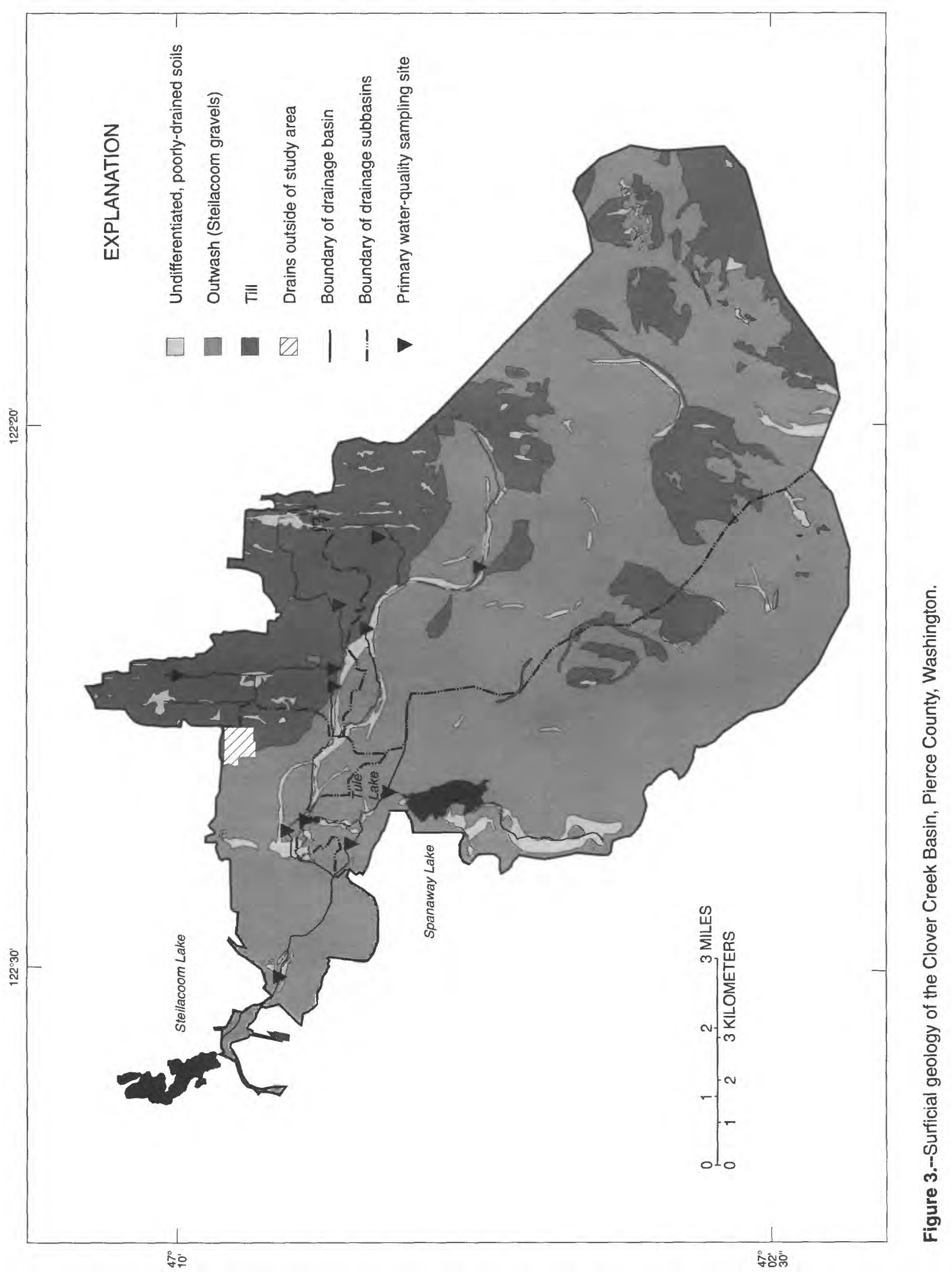




\section{Land-Use Practices}

The population of the basin has been generally increasing over the past several decades, and growth is expected to continue. As a result, sparsely populated rural areas of grass and forest are evolving into more-densely populated suburban and urban areas, and current land-use patterns within the basin are complex (fig. 4). In general, however, development tends to increase from the southeast to the northwest.

Land use within each of the subbasins has been separated into five categories: (1) lakes, (2) forest and grass cover, (3) low-density housing, (4) high-density housing, and (5) commercial, industrial, and transportation facilities (table 1). In the Upper Clover Creek subbasin, development generally increases from upstream to downstream. Overall, however, this is the least-developed subbasin in the study area, with approximately 90 percent of land use categorized as low-density housing. The Spanaway subbasin as a whole is only slightly more urbanized than the Upper Clover Creek subbasin, but development is highly concentrated in the area east and north of Spanaway Lake. Land use in the North Fork subbasin is primarily low-density housing. However, concentrated areas of more intense development occur in the northern part of the subbasin, which is drained by an unnamed tributary of the North Fork, locally referred to as Maple Creek. The Lower Clover Creek subbasin is the most urbanized part of the study area, with nearly 60 percent of land use categorized as high-density housing or commercial, industrial, and transportation facilities.

In order to investigate the effects of specific land-use practices on water quality in more detail, three small catchment areas within the basin were selected for study in addition to Clover Creek and its primary tributaries. Land use within each catchment area was categorized at a much finer scale than for the basin as a whole (table 1). The suburban catchment area, located in the Upper Clover Creek subbasin, consists of 10 acres of high-density single-family dwellings. The rural catchment area is a 90 -acre parcel of undeveloped forest and grassland in the North Fork subbasin and is currently used as pasture for cattle. Land use in the 120-acre mixed-use catchment, located in the North Fork subbasin, is primarily low- to high-density housing, but the catchment includes a small area of commercial development. The specific locations of these sites are presented in the data-collection network section of this report.

Table 1.--Subbasin land-use categories (in percent of total area) in the Clover Creek Basin, 1991-92

\begin{tabular}{|c|c|c|c|c|c|c|}
\hline & \multirow[b]{2}{*}{$\begin{array}{l}\text { Area } \\
\text { (square } \\
\text { miles) }\end{array}$} & \multicolumn{5}{|c|}{ Percentage of total area in land-use category } \\
\hline & & Lakes & $\begin{array}{l}\text { Forest and } \\
\text { grass cover }{ }^{2}\end{array}$ & $\begin{array}{l}\text { Low- } \\
\text { density } \\
\text { housing }^{3}\end{array}$ & $\begin{array}{l}\text { High- } \\
\text { density } \\
\text { housing } 4\end{array}$ & $\begin{array}{l}\text { Commercial, } \\
\text { industrial, } \\
\text { and trans- } \\
\text { portation } \\
\text { facilities }\end{array}$ \\
\hline \multicolumn{7}{|c|}{$\underline{\text { Subbasins }}$} \\
\hline Upper Clover Creek & 34.8 & 0 & 41 & 48 & 10 & 1 \\
\hline Spanaway & 18.8 & 2 & 42 & 37 & 16 & 2 \\
\hline North Fork & 6.2 & 0 & 21 & 63 & 13 & 4 \\
\hline Lower Clover Creek & 7.1 & 0 & 23 & 18 & 28 & 31 \\
\hline \multicolumn{7}{|c|}{ Catchment areas } \\
\hline $\begin{array}{l}\text { Suburban } \\
(\text { site } 340)^{5}\end{array}$ & ${ }^{6}(10)^{.01}$ & 0 & 0 & 0 & 100 & 0 \\
\hline $\begin{array}{l}\text { Rural } \\
{\text { (site } 365)^{5}}^{5}\end{array}$ & ${ }^{6}(90)^{.14}$ & 0 & 100 & 0 & 0 & 0 \\
\hline 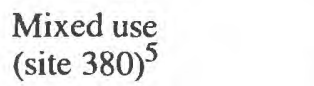 & ${ }^{6}(120)^{.19}$ & 0 & 0 & 68 & 29 & 3 \\
\hline
\end{tabular}

\footnotetext{
${ }^{1}$ Values generated from digitized coverages (M.C. Mastin, U.S. Geological Survey, written commun., 1993). Combined land-use categories for each subbasin may not total 100 percent because of rounding.

${ }^{2}$ Greater than 5 acres per housing unit.

${ }^{3} 1-5$ acres per housing unit.

${ }^{4}$ Less than 1 acre per housing unit.

${ }^{5}$ Site numbers refer to those given in table 2.

${ }^{6}$ Area in acres.
} 


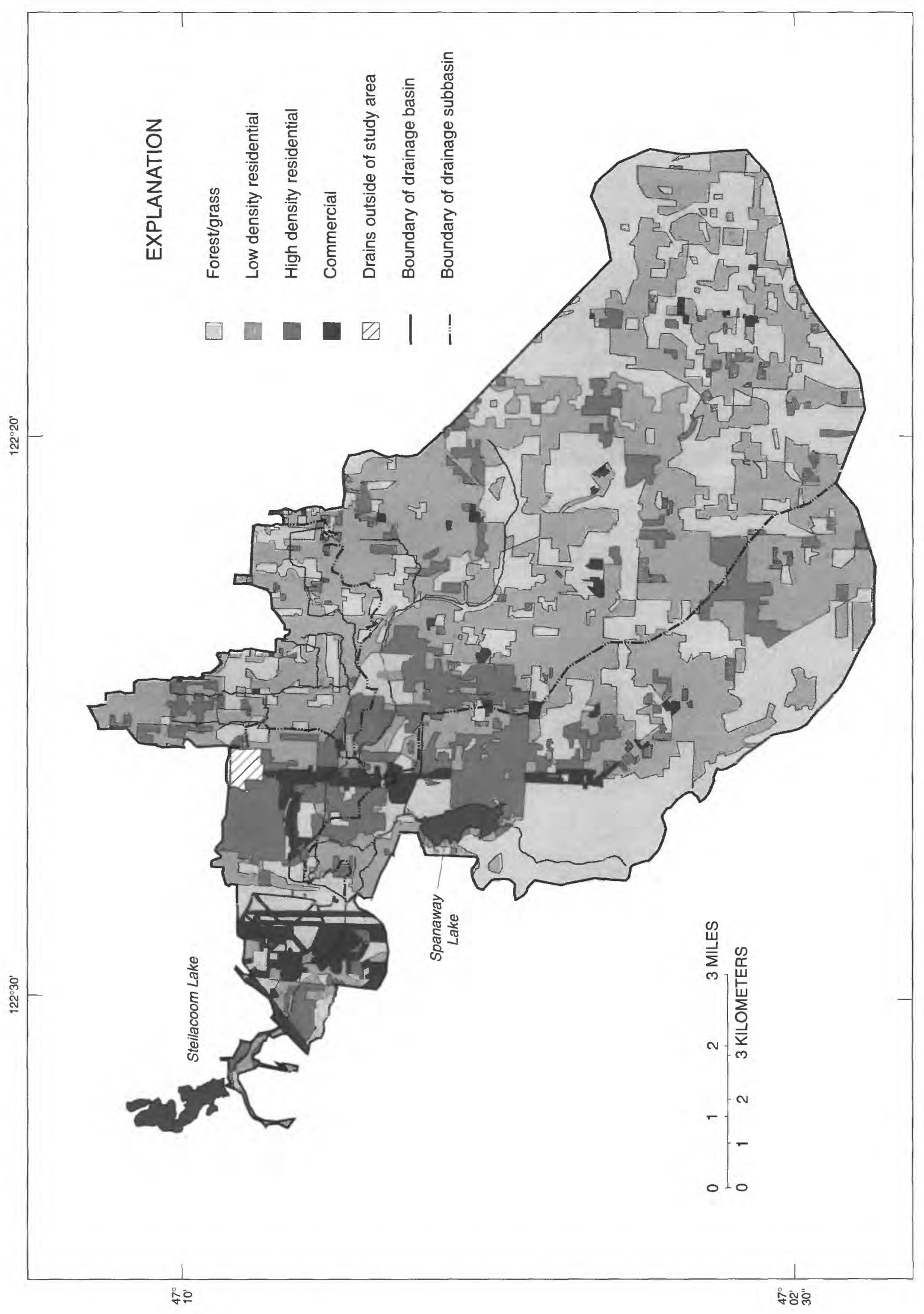

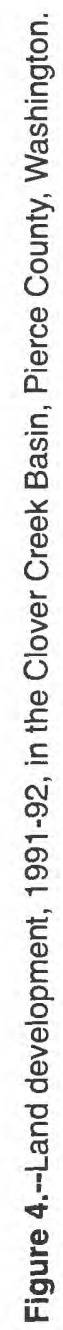




\section{Sewage and Stormwater Disposal Practices}

Until the mid-1970's, all sewage generated within the basin was disposed of by on-site waste-disposal systems, primarily septic tanks. In 1973, Pierce County formed a Utility Local Improvement District (ULID) to provide sewage-collection and off-site treatment services. The parts of the basin currently served by the ULID sewagecollection project are shown on figure 5. Although the project has expanded beyond its initial phase, most of the Upper Clover Creek, Spanaway, and North Fork subbasins and a portion of the Lower Clover Creek subbasin remain unsewered and continue to rely on on-site subsurface systems, primarily septic tanks, for waste disposal.

In addition to domestic, commercial, and industrial sewage, a substantial quantity of waste water is produced as stormwater runoff from streets and other impervious surfaces. In the urbanized parts of the basin, stormwater is collected and disposed of by discharge into streams, lakes, or drywells. The locations of stormwater outfalls that discharge directly into surface-water bodies are shown on figure 5 .

\section{DATA COLLECTION}

Water-quality and stream-discharge data were collected in order to assess the spatial and temporal variability of water quality within the Clover Creek Basin. The following sections describe the network of data-collection sites, the water-quality constituents upon which the study focused, and the methods of sample collection and quality assurance.

\section{Data-Collection Network}

Most of the water-quality and streamflow data were collected from 15 surface-water sites within the study area. The designations and locations of these sites are given in table 2 and on figure 6 . Site numbers are the last three digits of the eight-digit streamflow station numbers assigned by the U.S. Geological Survey (for example, site 330 in table 2 refers to station number 12090330). The sites are numbered in downstream order along Clover Creek, and tributaries are numbered in the order in which they enter Clover Creek.
Twelve of the sites were located on the principal streams of the basin: Clover Creek, the North Fork of Clover Creek, Maple Creek, Spanaway Creek, and Morey Creek. The other three sites were located on the relatively minor outflows of the small, well-characterized catchment areas discussed previously in the section on land-use practices. These 15 primary data-collection sites were sampled over a 16-month period from January 1991 through April 1992. Data were collected under both base- and storm-flow conditions, and a session of frequent sampling over a 24-hour period was conducted in September 1991 in order to assess diurnal fluctuations in water quality. Sampling sessions preceded by at least 1 week of dry weather (trace amounts, or less, of precipitation) were assumed to represent base-flow conditions. Sampling sessions conducted during or within 3 days after measurable rainfall were assumed to represent storm-flow conditions. Whenever possible, all sites were sampled synoptically. However, streamflow ceases during the summer and early fall at the three catchment areas (sites 340, 365 , and 380), in parts of the North Fork subbasin (sites 370, 395, and 400), and at sites 360 (Upper Clover Creek subbasin) and 430 (Lower Clover Creek subbasin), and as a result, these sites were not included in all sampling sessions. In particular, it should be noted that these sites were not included in the 24-hour sampling period in September 1991.

Supplemental water-quality data were collected at four additional surface-water sites, designated as secondary data-collection sites, and two precipitation-collection sites (table 2; fig. 6). Data from these sites are included in Appendix A, but because of their limited number, they are not included in the discussion of water quality.

Finally, historical data available from two sites within the basin (table 2; fig. 6) were used to explore long-term temporal water-quality trends in the study area. 


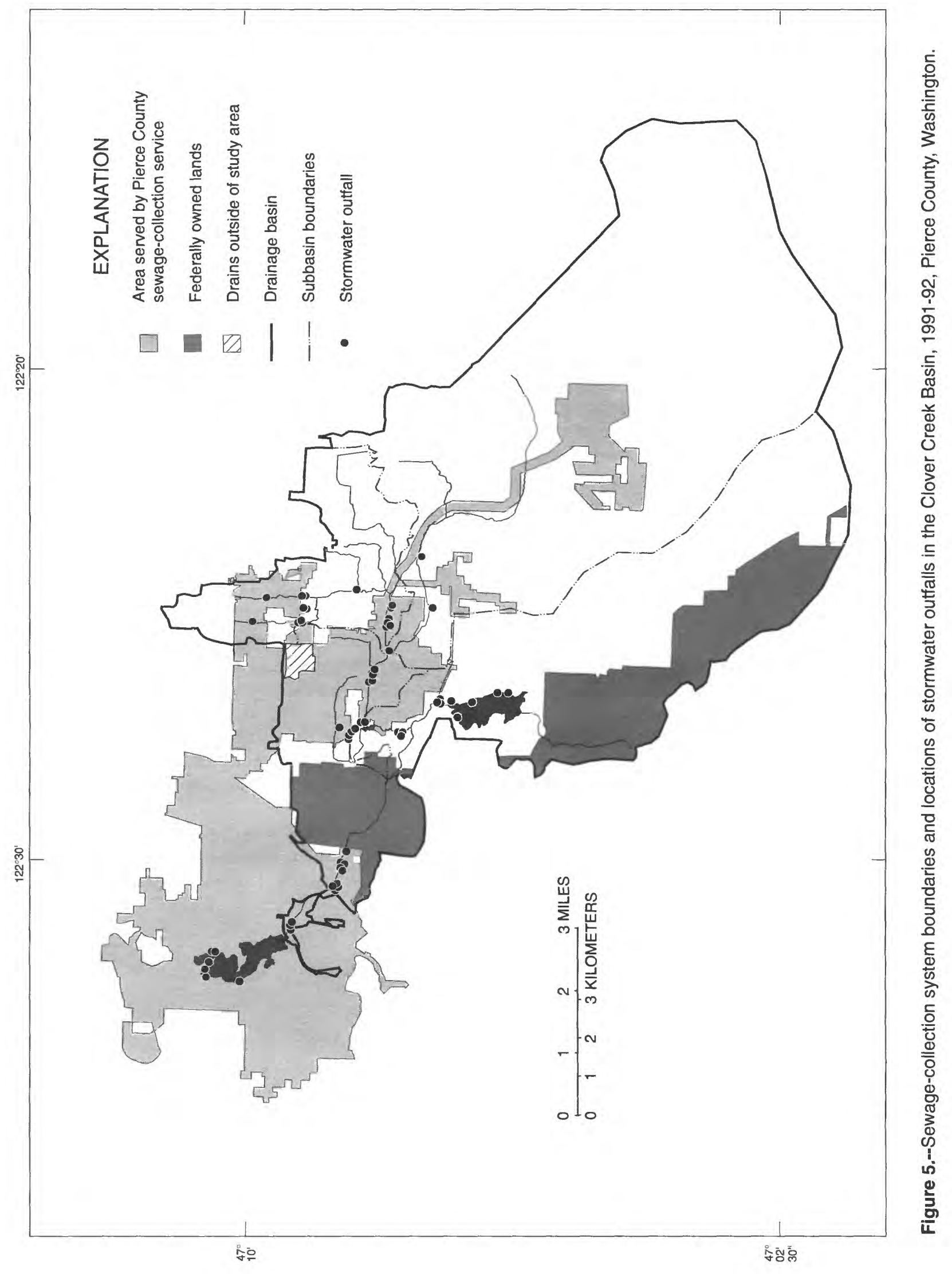




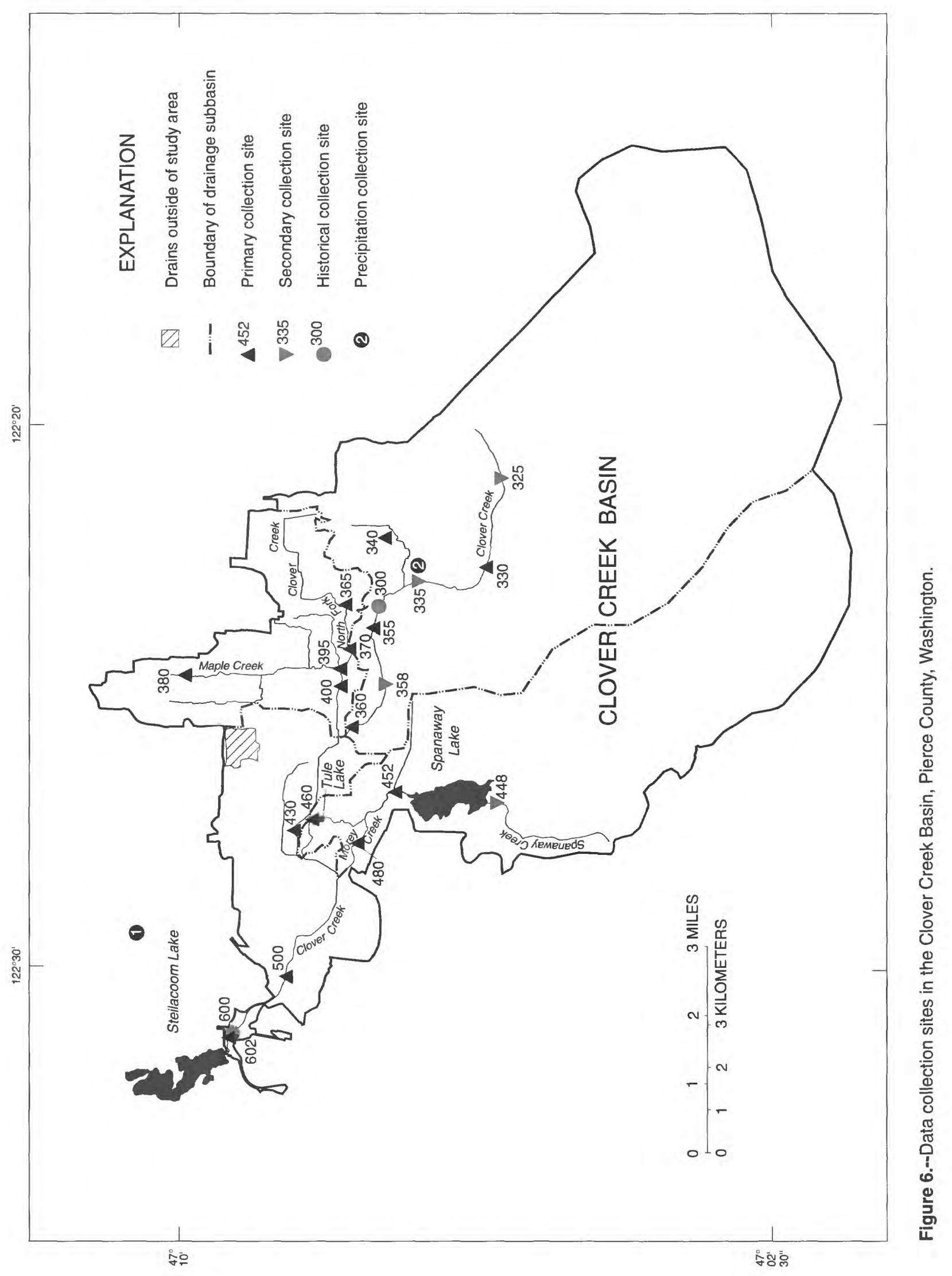




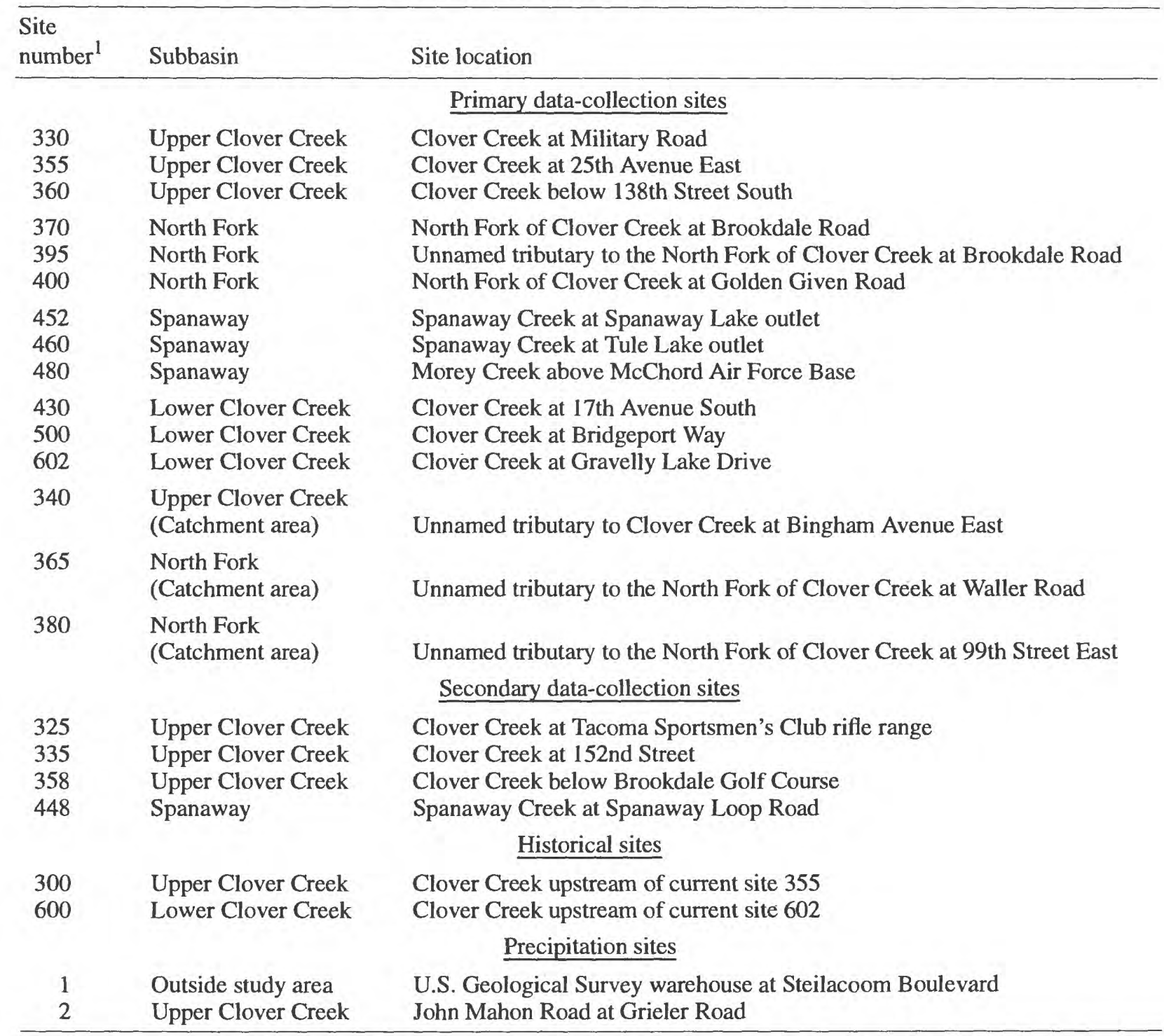

${ }^{1}$ Site numbers, except for 1 and 2 for the two precipitation sites, are the last three digits of the eight-digit stream-flow station numbers assigned by the U.S. Geological Survey (for example, site 330 refers to station number 12090330).

\section{Selection of Target Water-Quality Constituents}

In accordance with the objectives of this study, the water-quality constituents selected as the focus of the investigation were those that (1) are commonly associated with urbanization and (2) may pose a threat to receiving waters. These constituents include nitrogen and phosphorus compounds (commonly referred to as nutrients), copper, lead, zinc, and fecal bacteria.
Sources of nitrogen and phosphorus associated with urbanization include domestic waste water, fertilizers, and animal wastes. When these elements are present in high concentrations in water in a form available to biota, the water is said to be eutrophic. Particularly in lakes, where low velocities promote warmer temperatures, eutrophic conditions favor excessive growth of nuisance plants such as algae. Once eutrophic conditions have been established, decomposing algae and other plants, along with excreta from water fowl, serve as ongoing sources of nutrients within lakes and streams. In addition to being directly associated with the problem of nuisance algal blooms, high concentrations of nitrogen and phosphorus also serve as general indicators of water-quality degradation. 
During a nationwide investigation of urban-runoff quality, the USEPA found that the most prevalent priority pollutants associated with urbanization were metals, particularly copper, lead, and zinc (U.S. Environmental Protection Agency, 1983). Metals such as copper, lead, and zinc are known hazards to many forms of aquatic life. The USEPA study (1983) also concluded that bacteria associated with human and animal feces, such as fecal coliform and fecal streptococci bacteria, are another common constituent of urban runoff, particularly during storms when they are washed off impervious surfaces. In addition to being human pathogens, these bacteria also serve as general indicators of water-quality degradation.

Along with the target constituents described above, chloride, specific conductance, $\mathrm{pH}$, temperature, and suspended sediment were measured to provide further insight into water-quality conditions in the basin. Supplemental data collected on a limited basis included concentrations of sulfate, fluoride, dissolved oxygen, and biochemical oxygen demand. Samples for determination of the elemental composition of bed-sediment materials were collected on a single occasion at sites $330,480,500$, and 602 . Samples for selected organic analyses were collected at sites 430 and 460 (one occasion each), at sites 480 and 500 (three occasions each), and at site 602 (two occasions). A complete listing of the constituents measured over the course of the current study is provided in table 3. All water-quality data collected over the course of the study, including those from the secondary data-collection sites and precipitation-collection sites, are presented in Appendix A; table 3 indicates the table in Appendix A in which data for each constituent can be found.

\section{Sample Collection and Quality Assurance}

Water samples were collected using the equal-width increment method (Edwards and Glysson, 1988), and sample processing was done according to the methods of M.A. Sylvester, L.R. Kister, and W.B. Garrett, W.B. (U.S. Geological Survey, written commun., 1990). Specific conductance, $\mathrm{pH}$, temperature, and dissolved oxygen concentrations were determined in the field using standard U.S. Geological Survey procedures (M.A. Sylvester, L.R. Kister, and W.B. Garrett, U.S.Geological Survey, written commun., 1990), and the methods of Britton and Greeson (1987) were used for bacterial counts. All other analyses were done by the U.S. Geological Survey's National Water Quality Laboratory (NWQL) in Arvada, Colo. Fishman and Friedman (1989) and Wershaw and others (1987) provide descriptions of the analytical procedures used at the NWQL. In addition to the manual sampling just described, automated monitors installed at two of the sites ( 355 and 500) provided hourly measurements of stream discharge, specific conductance, temperature, and $\mathrm{pH}$.

Procedures used in the field to assure the quality of data included processing of blank samples, collection of duplicate samples, and frequent calibration of meters. Blank samples were prepared by processing deionized water in the same manner as stream samples. Duplicate samples were collected on a random basis for analyses of nitrogen and phosphorus compounds, chloride, sulfate, fluoride, suspended sediment, bacteria, metals, and biological oxygen demand. Specific conductance and dissolved-oxygen meters were calibrated once each day and $\mathrm{pH}$ meters twice each day. In addition to the procedures used in the field, standard quality-assurance procedures were used at the NWQL.

The results of blank and duplicate sample analyses are shown in Appendix B. Blank sample results show that dissolved ammonia and chloride were the only constituents present in concentrations greater than the laboratory reporting limit. Chloramines resulting from chlorination of the blank water prior to distilling and deionizing were a likely source of these constituents. Ammonia present in the atmosphere is another likely source of ammonia in blank water. Chloride concentrations in the blanks were approximately one order of magnitude lower than stream water and therefore did not pose a problem for this study. The ammonia concentrations found in blank samples were taken into consideration when ammonia data were interpreted.

In general, duplicate data pairs agree well. With the exception of chloride, the largest discrepancies are associated with analyses that included undissolved constituents (total ammonia plus organic nitrogen, total phosphorus, suspended sediment, bacteria, and total metals). This association is to be expected and reflects the fact that undissolved constituents tend to be less uniformly distributed within water than dissolved constituents.

The results of the chloride analyses suggest the presence of a sampling, processing, or analytical problem. In some cases, anomalously high chloride concentrations (approximately an order of magnitude greater than the concentrations reported in Appendixes A and B) were traced to contamination from hydrochloric acid used to clean equipment between collection and processing of samples for metals analyses. These data were deleted from the database. The cause of the discrepancies in the chloride data pairs shown in Appendix B is unknown. Therefore, chloride data were considered to be approximate. 
Table 3.--Water-quality constituents measured in the Clover Creek Basin, 1991-92

\begin{tabular}{|c|c|c|}
\hline Constituent name & $\begin{array}{l}\text { Data } \\
\text { location in } \\
\text { Appendix A }\end{array}$ & $\begin{array}{l}\text { Laboratory } \\
\text { parameter } \\
\text { code }\end{array}$ \\
\hline Instantaneous stream discharge (cubic feet per second) & Table A1 & 00061 \\
\hline Specific conductance (microsiemens per centimeter at 25 degrees Celsius) & Table Al & 00095 \\
\hline Suspended sediment (milligrams per liter) & Table A1 & 80154 \\
\hline Chloride, dissolved (milligrams per liter as chloride) & Table A1 & 00940 \\
\hline Sulfate, dissolved (milligrams per liter as sulfate) & Table A1 & 00945 \\
\hline Fluoride, dissolved (milligrams per liter as fluoride) & Table A1 & 00950 \\
\hline Dissolved nitrite plus nitrate (milligrams per liter as nitrogen) & Table A2 & 00631 \\
\hline Ammonia, dissolved (milligrams per liter as nitrogen) & Table A2 & 00608 \\
\hline Total ammonia plus organic nitrogen (milligrams per liter as nitrogen) & Table A2 & 00625 \\
\hline Nitrite, dissolved (milligrams per liter as nitrogen) & Table A2 & 00613 \\
\hline Orthophosphate, dissolved (milligrams per liter as phosphorus) & Table A2 & 00671 \\
\hline Phosphorus, total (milligrams per liter as phosphorus) & Table A2 & 00665 \\
\hline Water temperature (degrees Celsius) & Table A3 & 00010 \\
\hline $\mathrm{pH}$ (standard units) & Table A3 & 00400 \\
\hline Fecal coliform, (colonies per 100 milliliters) & Table A3 & 31625 \\
\hline Fecal streptococci (colonies per 100 milliliters) & Table A3 & 31673 \\
\hline Oxygen, dissolved (milligrams per liter) & Table A3 & 00300 \\
\hline Biochemical-oxygen demand, 5-day at 20 degrees Celsius (milligrams per liter) & Table A3 & 00310 \\
\hline Biochemical-oxygen demand, ultimate (milligrams per liter) & Table A3 & 00320 \\
\hline Copper, dissolved (micrograms per liter as copper) & Table A4 & 01040 \\
\hline Copper, total recoverable (micrograms per liter as copper) & Table A4 & 01042 \\
\hline Lead, dissolved (micrograms per liter as lead) & Table A4 & 01049 \\
\hline Lead, total recoverable (micrograms per liter as lead) & Table A4 & 01051 \\
\hline Zinc, dissolved (micrograms per liter as zinc) & Table A4 & 01090 \\
\hline Zinc, total recoverable (micrograms per liter as zinc) & Table A4 & 01092 \\
\hline Aluminum (percent $\left.{ }^{1}\right)$ & Table A5 & 34792 \\
\hline Arsenic (micrograms per gram $^{1}$ ) & Table A5 & 34802 \\
\hline Barium (micrograms per gram ${ }^{1}$ ) & Table A5 & 34807 \\
\hline Beryllium (micrograms per gram $^{1}$ ) & Table A5 & 34812 \\
\hline Bismuth (micrograms per gram $^{1}$ ) & Table A5 & 34817 \\
\hline Cadmium (micrograms per gram ${ }^{1}$ ) & Table A5 & 34827 \\
\hline Calcium (percent ${ }^{1}$ ) & Table A5 & 34832 \\
\hline Cerium (micrograms per gram $^{1}$ ) & Table A5 & 34837 \\
\hline Chromium (micrograms per gram $^{1}$ ) & Table A5 & 34842 \\
\hline Cobalt (micrograms per $\operatorname{gram}^{1}$ ) & Table A5 & 34847 \\
\hline Copper (micrograms per gram $^{1}$ ) & Table A5 & 34852 \\
\hline Europium (micrograms per gram $^{1}$ ) & Table A5 & 34857 \\
\hline
\end{tabular}


Table 3.--Water-quality constituents measured in the Clover Creek Basin, 1991-92--Continued

\begin{tabular}{|c|c|c|}
\hline Constituent name & $\begin{array}{l}\text { Data } \\
\text { location in } \\
\text { Appendix A }\end{array}$ & $\begin{array}{l}\text { Laboratory } \\
\text { parameter } \\
\text { code }\end{array}$ \\
\hline Gallium (micrograms per gram $^{1}$ ) & Table A5 & 34862 \\
\hline Gold ((micrograms per gram $\left.^{1}\right)$ & Table A5 & 34872 \\
\hline Holmium (miçrograms per $\operatorname{gram}^{1}$ ) & Table A5 & 34877 \\
\hline Iron (percent $\left.{ }^{1}\right)$ & Table A5 & 34882 \\
\hline Lanthanum (micrograms per gram $^{1}$ ) & Table A5 & 34887 \\
\hline Lead (micrograms per $\operatorname{gram}^{1}$ ) & Table A5 & 34892 \\
\hline Lithium (micrograms per gram $^{1}$ ) & Table A5 & 34897 \\
\hline Magnesium (percent ${ }^{1}$ ) & Table A5 & 34902 \\
\hline Manganese (micrograms per gram $^{1}$ ) & Table A5 & 34907 \\
\hline Molybdenum (micrograms per gram $^{1}$ ) & Table A5 & 34917 \\
\hline Neodymium (micrograms per gram $^{1}$ ) & Table A5 & 34922 \\
\hline Nickel (micrograms per gram $^{1}$ ) & Table A5 & 34927 \\
\hline Niobium (micrograms per gram $^{1}$ ) & Table A5 & 34932 \\
\hline Phosphorus (percent $t^{1}$ ) & Table A5 & 34937 \\
\hline Potassium (percent ${ }^{1}$ ) & Table A5 & 34942 \\
\hline Scandium (micrograms per gram $^{1}$ ) & Table A5 & 34947 \\
\hline Silver (micrograms per $\operatorname{gram}^{1}$ ) & Table A5 & 34957 \\
\hline Sodium (percent ${ }^{1}$ ) & Table A5 & 34962 \\
\hline Strontium (micrograms per gram $^{1}$ ) & Table A5 & 34967 \\
\hline Tantalum (micrograms per gram $^{1}$ ) & Table A5 & 34977 \\
\hline Thorium (micrograms per gram $^{1}$ ) & Table A5 & 34982 \\
\hline Tin (micrograms per gram ${ }^{1}$ ) & Table A5 & 34987 \\
\hline Titanium (percent ${ }^{1}$ ) & Table A5 & 34992 \\
\hline Uranium (micrograms per $\operatorname{gram}^{1}$ ) & Table A5 & 35002 \\
\hline Vanadium (micrograms per gram ${ }^{1}$ ) & Table A5 & 35007 \\
\hline Yttrium (micrograms per gram $^{1}$ ) & Table A5 & 35012 \\
\hline Ytterbium (micrograms per gram $^{1}$ ) & Table A5 & 35017 \\
\hline Zinc (micrograms per gram ${ }^{1}$ ) & Table A5 & 35022 \\
\hline Dibromomethane, water, whole, recoverable (micrograms per liter) & Table A6 & 30217 \\
\hline Dichlorobromomethane, total (micrograms per liter) & Table A6 & 32101 \\
\hline Carbon tetrachloride, total (micrograms per liter) & Table A6 & 32102 \\
\hline 1,2-Dichloroethane, total (micrograms per liter) & Table A6 & 32103 \\
\hline Bromoform, total (micrograms per liter) & Table A6 & 32104 \\
\hline Chlorodibromomethane, total (micrograms per liter) & Table A6 & 32105 \\
\hline Chloroform, total (micrograms per liter) & Table A6 & 32106 \\
\hline Toluene, total (micrograms per liter) & Table A6 & 34010 \\
\hline Benzene, total (micrograms per liter) & Table A6 & 34030 \\
\hline Acrolein, total (micrograms per liter) & Table A6 & 34210 \\
\hline Acrylonitrile, total (micrograms per liter) & Table A6 & 34215 \\
\hline
\end{tabular}


Table 3.--Water-quality constituents measured in the Clover Creek Basin, 1991-92--Continued

\begin{tabular}{|c|c|c|}
\hline Constituent name & $\begin{array}{l}\text { Data } \\
\text { location in } \\
\text { Appendix A }\end{array}$ & $\begin{array}{l}\text { Laboratory } \\
\text { parameter } \\
\text { code }\end{array}$ \\
\hline Chlorobenzene, total (micrograms per liter) & Table A6 & 34301 \\
\hline Chloroethane, total (micrograms per liter) & Table A6 & 34311 \\
\hline Ethylbenzene, total (micrograms per liter) & Table A6 & 34371 \\
\hline Methylbromide, total (micrograms per liter) & Table A6 & 34413 \\
\hline Methylchloride, total (micrograms per liter) & Table A6 & 34418 \\
\hline Methylenechloride, total (micrograms per liter) & Table A6 & 34423 \\
\hline Tetrachloroethylene, total (micrograms per liter) & Table A6 & 34475 \\
\hline Trichlorofluoromethane, total (micrograms per liter) & Table A6 & 34488 \\
\hline 1,1-Dichloroethane, total (micrograms per liter) & Table A6 & 34496 \\
\hline 1,1-Dichloroethylene, total (micrograms per liter) & Table A6 & 34501 \\
\hline 1,1,1-Trichloroethane, total (micrograms per liter) & Table A6 & 34506 \\
\hline 1,1,2-Trichloroethane, total (micrograms per liter) & Table A6 & 34511 \\
\hline $1,1,2,2$-Tetrachloroethane, water, unfiltered, recoverable (micrograms per liter) & Table A6 & 34516 \\
\hline$o$-Chlorobenzene, water, unfiltered, recoverable (micrograms per liter) & Table A6 & 34536 \\
\hline 1,2-Dichloropropane, total (micrograms per liter) & Table A6 & 34541 \\
\hline 1,2-trans-Dichloroethene, water, total (micrograms per liter) & Table A6 & 34546 \\
\hline 1,2,4-Trichlorobenzene, water, unfiltered, recoverable (micrograms per liter) & Table A6 & 34551 \\
\hline 1,3-Dichloropropene, water, total (micrograms per liter) & Table A6 & 34561 \\
\hline 1,3-Dichlorobenzene, water, unfiltered, recoverable (micrograms per liter) & Table A6 & 34566 \\
\hline 1,4-Dichlorobenzene, water, unfiltered, recoverable (micrograms per liter) & Table A6 & 34571 \\
\hline 2-Chloroethylvinylether, total (micrograms per liter) & Table A6 & 34576 \\
\hline Dichlorodifluoromethane, total (micrograms per liter) & Table A6 & 34668 \\
\hline Naphthalene, total (micrograms per liter) & Table A6 & 34696 \\
\hline 1,3-trans-Dichloropropene, total (micrograms per liter) & Table A6 & 34699 \\
\hline 1,3-cis-Dichloropropene, total (micrograms per liter) & Table A6 & 34704 \\
\hline Vinylchloride, total (micrograms per liter) & Table A6 & 39175 \\
\hline Trichloroethylene, total (micrograms per liter) & Table A6 & 39180 \\
\hline Hexachlorobutadiene, total (micrograms per liter) & Table A6 & 39702 \\
\hline 1,2-cis-Dichloroethene, water, whole, total (micrograms per liter) & Table A6 & 77093 \\
\hline Styrene, total (micrograms per liter) & Table A6 & 77128 \\
\hline 1,1-Dichloropropene, water, whole, total (micrograms per liter) & Table A6 & 77168 \\
\hline 2,2-Dichloropropane, water, whole, total (micrograms per liter) & Table A6 & 77170 \\
\hline 1,3-Dichloropropane, water, whole, total (micrograms per liter) & Table A6 & 77173 \\
\hline Pseudocumene, water, unfiltered, recoverable (micrograms per liter) & Table A6 & 77222 \\
\hline Isopropylbenzene, water, whole, recoverable (micrograms per liter) & Table A6 & 77223 \\
\hline$n$-Propylbenzene, water, unfiltered, recoverable (micrograms per liter) & Table A6 & 77224 \\
\hline Mesitylene, water, unfiltered, recoverable (micrograms per liter) & Table A6 & 77226 \\
\hline$o$-Chlorotoluene, water, whole, total (micrograms per liter) & Table A6 & 77275 \\
\hline$p$-Chlorotoluene, water, unfiltered, recoverable (micrograms per liter) & Table A6 & 77277 \\
\hline$n$-Butylbenzene, water, unfiltered, recoverable (micrograms per liter) & Table A6 & 77342 \\
\hline
\end{tabular}




\begin{tabular}{llc}
\hline & $\begin{array}{l}\text { Data } \\
\text { location in } \\
\text { Appendix A }\end{array}$ & $\begin{array}{l}\text { Laboratory } \\
\text { parameter } \\
\text { code }\end{array}$ \\
\hline $\begin{array}{l}\text { sec-Butylbenzene, water, unfiltered, recoverable (micrograms per liter) } \\
\text { tert-Butylbenzene, water, unfiltered, recoverable (micrograms per liter) }\end{array}$ & $\begin{array}{l}\text { Table A6 } \\
\text { Table A6 }\end{array}$ & 77350 \\
-Isopropyltoluene, water, whole, recoverable (micrograms per liter) & Table A6 & 77353 \\
1,2,3-Trichloropropane, water, whole, total (micrograms per liter) & Table A6 & 77443 \\
1,1,1,2-Tetrachloroethane, water, unfiltered, recoverable (micrograms per liter) & Table A6 & 77562 \\
1,2,3-Trichlorobenzene, water, whole, recoverable (micrograms per liter) & Table A6 & 77613 \\
1,2-Dibromoethane, water, whole, total (micrograms per liter) & Table A6 & 77651 \\
Xylene, water, unfiltered, recoverable (micrograms per liter) & Table A6 & 81551 \\
Bromobenzene, water, whole, total (micrograms per liter) & Table A6 & 81555 \\
Dibromochloropropane, water, whole, total recoverable (micrograms per liter) & Table A6 & 82625 \\
\hline
\end{tabular}

${ }^{1}$ Concentration associated with streambed sediment finer than 63 micrometers in diameter.

\section{RESULTS AND DISCUSSION OF WATER-QUALITY ASSESSMENT}

This section of the report addresses the two primary objectives of the study - to describe the spatial and temporal water-quality characteristics of the basin and to provide an understanding of the influence of basin characteristics on water quality. First, a general discussion of the basin characteristics will be provided. Second, the water-quality data from each site will be presented and discussed in terms of the specific characteristics of the associated subbasin or catchment area. Third, the water-quality characteristics of the four subbasins and three catchment areas will be compared and contrasted, and the reasons for similarities and differences will be discussed. Fourth, the results of assessments of nitrogen and phosphorus loading to Steilacoom Lake will be presented. Finally, basin compliance with water-quality standards set forth by the State of Washington for dissolved oxygen, fecal coliform bacteria, ammonia, copper, lead, and zinc will be assessed.

\section{Basin Characteristics Affecting Water Quality}

The four characteristics that likely affect the quality of water in the Clover Creek Basin most significantly are the permeability of surficial geologic materials, land use, sewage- and stormwater-disposal methods, and the presence of lakes within subbasins. Although water quality is ultimately the result of complex, interrelated processes governed by these and many additional secondary characteristics, these four characteristics were found to have specific, dominant effects that warrant discussion.

\section{Permeability of Surficial Geologic Materials}

The permeability of surficial geologic materials influences surface-water quality in two important ways. First, the permeability of the land surface and shallow subsurface governs the extent to which precipitation will infiltrate. Second, the permeability of the ground-water zone determines the rate at which ground water and its waterquality constituents move through the subsurface before eventually being discharged as surface water.

Low-permeability materials, such as glacial tills, inhibit infiltration, and in areas underlain by such materials (fig. 3), storm runoff tends to flow directly to streams. The potential attenuation of harmful constituents and peak discharges afforded by movement through the subsurface is therefore decreased. In contrast, infiltration occurs readily into highly permeable materials such as glacial outwash. In areas underlain by glacial outwash (fig. 3), therefore, the subsurface may act as a buffer by filtering out or sorbing various constituents, promoting dilution through dispersion, and slowing water movement relative to surface transport. In addition to attenuating peak flows and concentrations, subsurface flow paths allow additional time for chemical and biological transformations to alter water quality. 
Although movement through any porous medium provides attenuation relative to surface streamflow, the degree of attenuation is influenced by the permeability of the material. Effluent from on-site waste-disposal systems and drywells constructed in highly permeable materials can move relatively quickly through the subsurface, and many associated water-quality constituents may be readily transported to streams in local discharge areas. Conversely, percolation from waste-disposal systems constructed in low-permeability materials will be inhibited, and effluent from shallow systems may follow surface, or near surface, pathways. In these cases, the attenuating effects of subsurface transport on the effluent from waste-disposal systems will be limited.

\section{Land Use}

Land-use practices typically affect water quality through two important mechanisms. First, several constituents that have the potential to degrade water quality are associated with particular land uses. For example, residential areas, parks, golf courses, and agricultural areas produce substantial amounts of nitrogen and phosphorus from domestic sewage, fertilizers, and wastes from animals such as cattle, dogs, cats, ducks, and rodents. Animal feces are also a source of bacteria. Wastes from vehicle traffic in developed areas include metals, hydrocarbon compounds, and dissolved nitrite plus nitrate compounds. Disturbance of natural riparian vegetation by construction activities or permanent land-use changes often results in increased bank erosion, which elevates concentrations of suspended sediment in the stream. In addition to increasing turbidity, which is aesthetically unpleasing and may be harmful to aquatic life, suspended sediment can enhance the transport of constituents such as metals, phosphorus, and organic compounds that tend to associate with solidphase materials.

A second mechanism by which land-use practices can affect water quality is alteration of the hydrologic response of an area through land development. Increased impervious areas such as roof tops, roadways and parking lots reduce infiltration into the subsurface. Storm runoff thus travels more directly to streams, and the potential attenuation of harmful constituents and peak discharges afforded by movement through the subsurface is decreased. Mastin (1996) provides a more detailed discussion of the effects of land development on hydrologic response within the Clover Creek Basin.

\section{Wastewater Disposal}

Because of the extensive use of subsurface on-site disposal systems to dispose of domestic waste water produced in the study area, effluent from these systems is considerable and ultimately reaches the shallow ground-water system. Although the ground-water flow system in the basin is not well understood at this time, Brown and Caldwell Consultants (1985) suggest that it is highly complex and that ground-water discharge to Clover Creek occurs in some areas. As will be shown, streamflow data collected by Mastin (1996) and streamflow and waterquality data collected as part of this study support this theory. Wastewater disposed of in the subsurface is, therefore, a potential source of local surface-water degradation.

Much of the stormwater runoff generated from impervious surfaces in developed areas is collected and routed to either streams or drywells. Runoff routed directly to streams is an obvious source of constituents that may threaten water quality, and similar to the on-site wastedisposal systems discussed above, stormwater runoff disposed of in subsurface drywells can also eventually affect water quality in streams.

\section{Lakes}

Lakes can substantially affect water quality because of their hydraulic effects. In most cases, once water enters a lake, its velocity decreases, and its capacity for carrying suspended materials is therefore reduced. As a result, suspended materials and species such as phosphorus, metals, and organic materials that are associated with solid-phase materials often settle to the bottom and are removed from the water column. Reduced water velocity also leads to increased hydraulic residence time in lakes, which allows mixing of dissolved constituents and equilibration between water and air temperatures. In addition to attenuating short-term, small-scale changes in water quality and discharge, reduced velocities and long residence times are favorable for the growth of a variety of organisms.

The effects of biological activity on the water quality of lakes can be considerable. The excreta of ducks, for example, can be a significant source of phosphorus to lake waters. Microorganisms, such as algae, utilize dissolved nitrogen and phosphorus compounds and other elements essential for life. When these organisms die and decay, soluble compounds are released and thus become available to other organisms. Much of the material that settles to the bottom is either utilized by benthic organisms or bound to bottom sediments. In lakes that stratify and 
undergo seasonal turnover, nutrients incorporated in bottom sediments are periodically mixed back into the water column. Some of the nutrients associated with these sediments are then released and are once again available to organisms in the water column. Thus, once elements are incorporated into biomass, they may remain within the lake rather than be flushed out, providing an ongoing source of nutrition to lake biota.

Change in $\mathrm{pH}$ resulting from biological activity can also influence water quality in lakes. Chemical reactions associated with photosynthesis and respiration alter $\mathrm{pH}$ in a complex manner. In turn, $\mathrm{pH}$ affects water quality through its influence on chemical equilibria. One example of this phenomenon is the equilibrium between un-ionized ammonia $\left(\mathrm{NH}_{3}\right)$ and the ammonium ion $\left(\mathrm{NH}_{4}{ }^{+}\right)$:

$$
\mathrm{NH}_{3} \cdot \mathrm{H}_{2} \mathrm{O} \leftrightarrow \mathrm{NH}_{4}^{+}+\mathrm{OH}^{-} .
$$

The relative abundance of these two ammonia species depends on $\mathrm{pH}$, with the un-ionized form being favored at higher $\mathrm{pH}$ 's and the ammonium ion being favored at lower $\mathrm{pH}$ 's. Therefore, because the deleterious effects of ammonia on higher aquatic organisms are believed to result from the $\mathrm{NH}_{3}$ species, ammonia toxicity is highly dependent on $\mathrm{pH}$.

The solubility of metals is also influenced by $\mathrm{pH}$. Elevated pH's, which commonly occur during times of peak biological activity, favor the formation of solid-phase metal hydroxides and organometallic complexes. Conversely, decreases in $\mathrm{pH}$ favor the dissolution of metals. Because solid-phase materials tend to accumulate in bed sediments and dissolved metals are more readily transported and available to biota, $\mathrm{pH}$ is a critical factor governing the toxicity of metals in aquatic environments.

\section{Water Quality in Subbasins and Catchment Areas}

The basin characteristics believed to affect water quality most significantly-surficial geology, land use, wastewater-disposal methods, and the presence of lakesdiffer considerably among the four subbasins and three catchment areas within the study area. The following sections will, therefore, discuss the water-quality characteristics of each subbasin and catchment area separately. Most of the data are grouped into three categories for each site-base-flow, storm-flow, and 24-hour-study measurements-and are presented graphically. However, water samples for metal analyses were collected less frequently than those for most constituents, and bed-sediment samples were collected only once at selected sites. These data are therefore summarized in tables.

\section{Upper Clover Creek Subbasin-- Sites 330, 355, and 360}

Two important characteristics of the Upper Clover Creek subbasin, in terms of their effects on water quality, are the glacial outwash materials that dominate the subbasin's surficial geology (fig. 3 ) and the extensive area still served by subsurface waste-disposal systems (fig. 5). Landscaping activities, particularly the use of fertilizers, may also have a substantial effect on water quality in the subbasin. The highly permeable nature of the glacial outwash material allows rapid infiltration and promotes considerable interaction between surface and ground water. As will be discussed, data collected from Upper Clover Creek indicate that this interaction has a strong influence on the quality of water in this subbasin.

Relatively little change in either stream discharge or the concentrations of water-quality constituents was observed in this subbasin between base- and storm-flow conditions (figs. 7-10). This lack of change was particularly noticeable at site 330 , the most upstream site in the subbasin. The most probable reason for this behavior is that site 330 lies within a ground-water discharge area, and even during storms most discharge results from ground water rather than surface runoff. Several specific factors indicate that ground water is the major source of streamflow at site 330 .

One indication that streamflow at site 330 results primarily from ground-water discharge is that stream discharge measured during storms was not substantially greater than that measured during base-flow conditions (fig. 7). This attenuated response to rainfall indicates that precipitation infiltrates readily through the highly permeable glacial outwash materials that dominate this subbasin, entering the ground-water system rather than following more direct surface or shallow subsurface pathways to the stream channel. Furthermore, because ground-water flow is relatively slow and subsurface pathways are long, ample time and distance are available for the dispersion process to mix infiltrating water with existing ground water. As a result, short-term temporal and small-scale spatial variations in water quality are attenuated, and many properties tend to be stable, reflecting only long-term, large-scale changes. This phenomenon is likely responsible for the steady nature of specific conductance, nutrient concentrations, and temperature observed at this site (figs. 7-10). 
A second indication that ground water is the major source of streamflow is that ammonia concentrations at site 330 were among the lowest measured in the entire Clover Creek Basin, whereas the dissolved nitrite plus nitrate concentrations were among the highest (fig. 8). (Direct comparisons of water quality in all subbasins and catchment areas are provided in a later section). These concentrations are also consistent with a ground-water source. Although fertilizer leachate and on-site waste-disposal systems can be significant sources of ammonia, ammonia is readily oxidized first to nitrite and then to nitrate by nitrifying bacteria. Such bacteria are ubiquitous in the subsurface, and the long travel times associated with ground-water flow allow ample time for biodegradation processes to convert ammonia to nitrate. A second means by which ammonia is lost from solution is adsorption of the ammonium ion to clay minerals. As a result of these two mechanisms, ongoing subsurface sources of ammonia can result in down-gradient ground water characterized by low ammonia and high dissolved nitrite plus nitrate concentrations.

Another indication that ground water contributes substantially to streamflow at site 330 is the low concentrations of suspended sediment measured there, which were consistently less than $5 \mathrm{mg} / \mathrm{L}$ (milligrams per liter) (fig. 7). The filtering capability of porous media and the low velocities typical of subsurface flow allow very little suspended material to be transported through ground-water systems. As a result, suspended-sediment concentrations in streams are typically low in reaches dominated by ground-water discharge. Because a large portion of the phosphorus in aquatic systems tends to be bound to solid-phase materials such as the aquifer matrix or suspended sediment, low suspended-sediment concentrations may partly account for the relatively low concentrations of total phosphorus observed at site 330 (fig. 9). In contrast, total ammonia plus organic nitrogen concentrations (fig. 8) were not particularly low at this site, even though a considerable portion of this material likely consists of large, hydrophobic macromolecules that are commonly assumed to be readily sorbed and thus relatively immobile in porous media. This contrast between the observed concentrations of total phosphorus and total ammonia plus organic nitrogen may be explained by the work of McCarthy and others (1993), which indicates that natural organic matter in ground water quickly approaches equilibrium with the immobile solid phase. As equilibrium is approached, the rate of desorption from the solid phase approaches the rate of sorption. As a result, natural organic matter can be readily transported by ground water when long-term sources are available. In addition, aquatic organisms and riparian vegetation likely act as local surface sources of organic nitrogen.

Bacteria counts at site 330 were observed to increase somewhat during storms (fig. 10), but were, nonetheless, among the lowest in the entire basin. These low numbers indicate that direct surface runoff from developed parts of the subbasin does not contribute substantially to flow at this site because wash off and short travel times associated with such surface runoff generally result in high numbers of fecal coliform and fecal streptococci.

Metal concentrations at site 330 were relatively low in both the water column (table 4) and stream-bed sediments (table 5). Concentrations of all elements measured in bed sediment at this site fell within the range of 95 percent of western United States soils (Severson, Wilson, and $\mathrm{McNeal}, 1987)$. These low concentrations can be attributed to two factors. First, moderate to high concentrations of metals generally do not result from rural areas such as the upper part of the subbasin. Second, the mobility of metals in ground water is low due to both sorption to aquifer materials and precipitation as solid-phase minerals. Therefore, because ground water is likely a major source of streamflow in the subbasin, even if sources of metals are present in the subsurface (for example, on-site waste-disposal systems and drywells), it is likely that a considerable portion of these metals will be immobilized before reaching streams.

Finally, a comparison of historic ground-water quality with current surface-water quality at site 330 provides additional evidence that implicates ground water as the source of streamflow at this site. Littler, Aden, and Johnson (1981) and Brown and Caldwell Consultants $(1985,1991)$ attributed nitrate and chloride concentrations in local ground water to effluent from on-site waste-disposal systems. Similar concentrations of dissolved nitrite plus nitrate and chloride were measured at site 330 during this study. Specific-conductance values measured during the current study were also similar to those measured historically in ground water. 

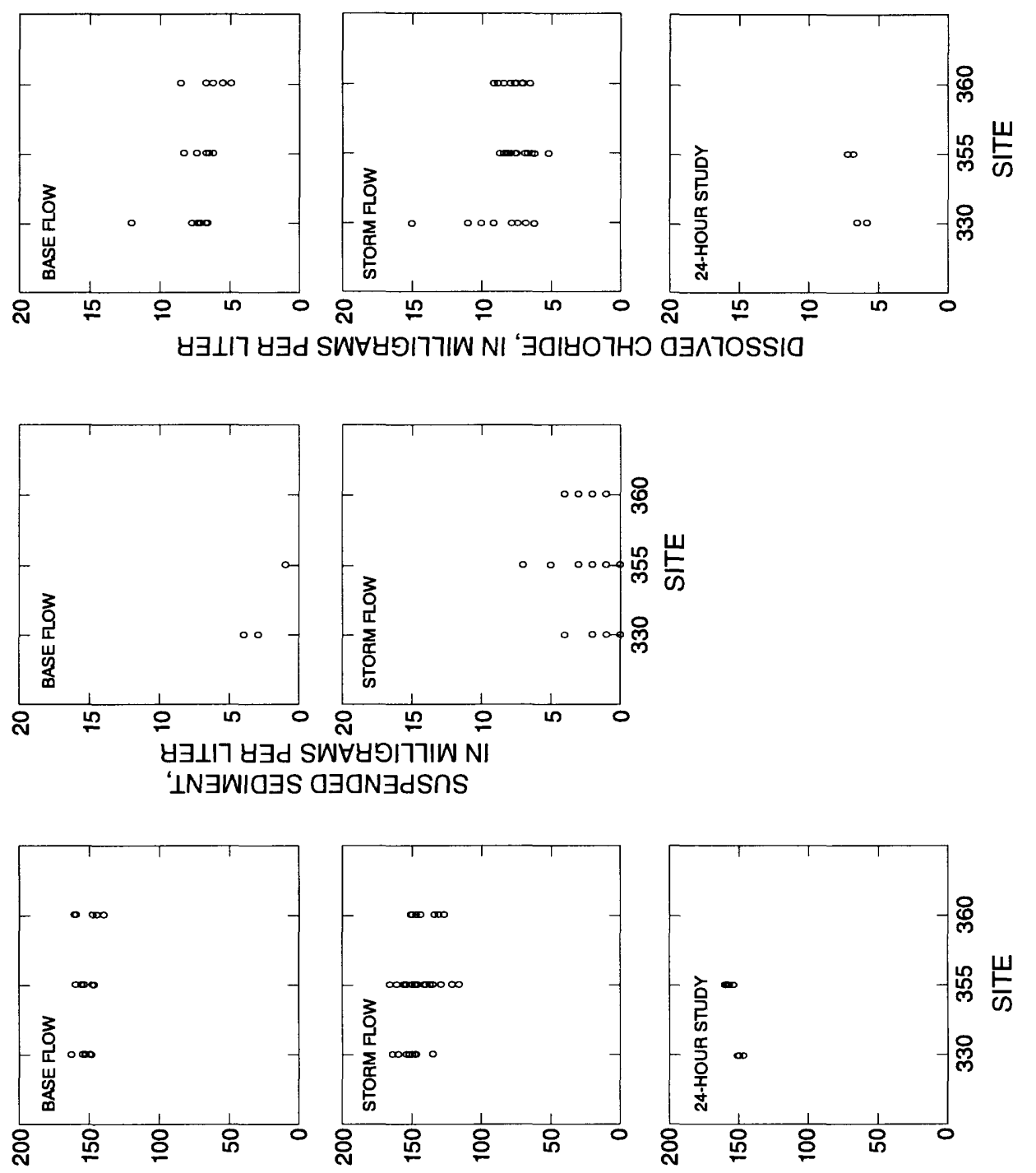

SกISTヨว S

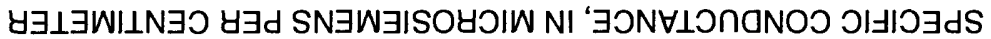
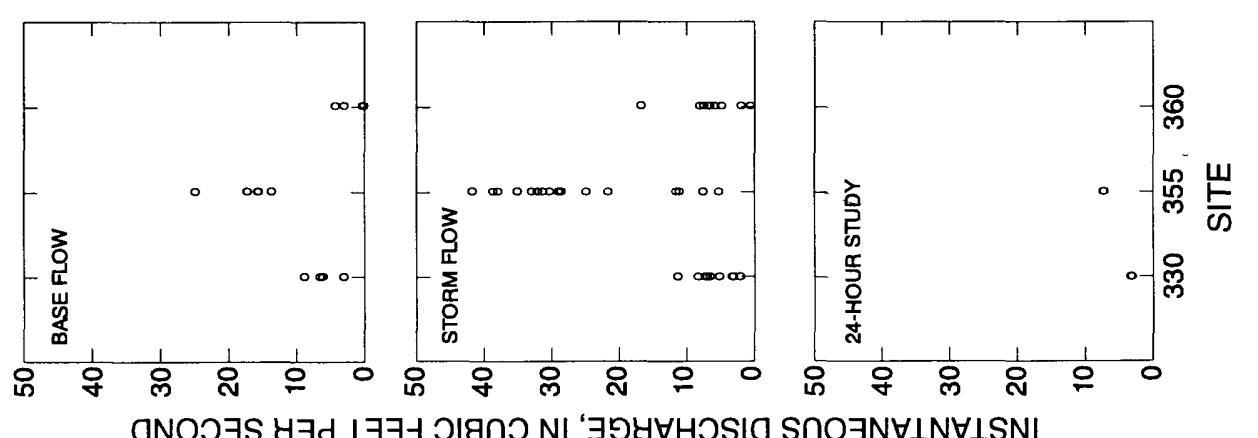

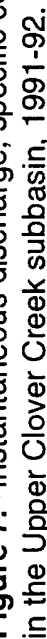

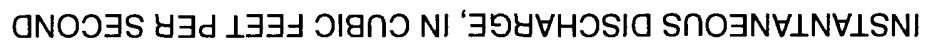



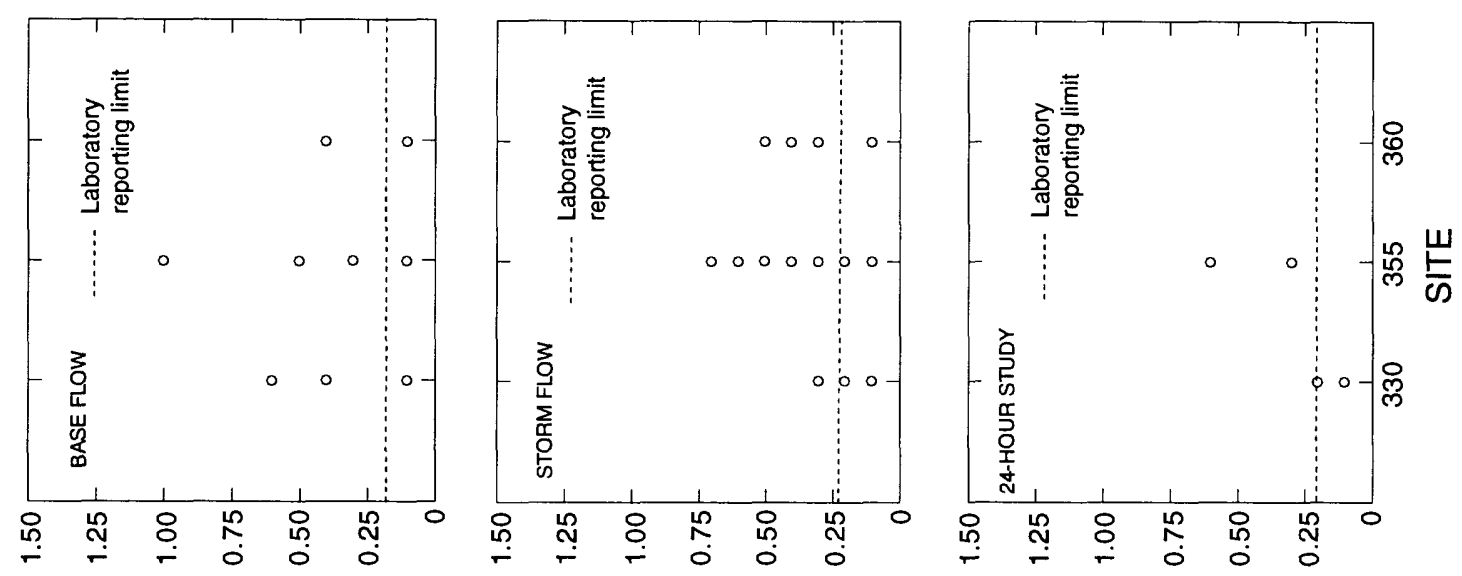

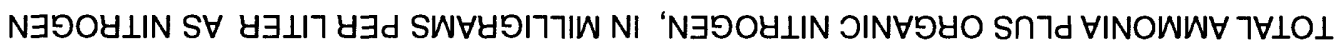
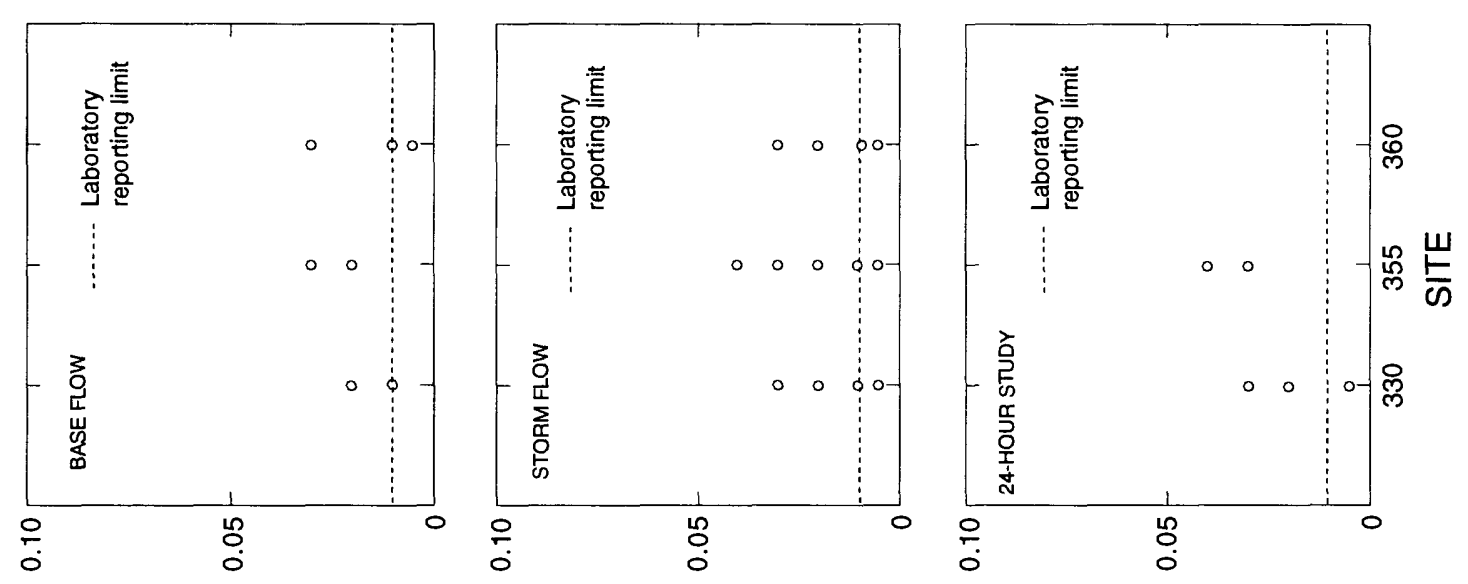

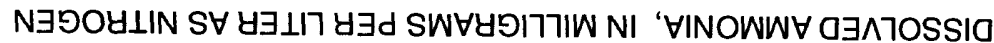
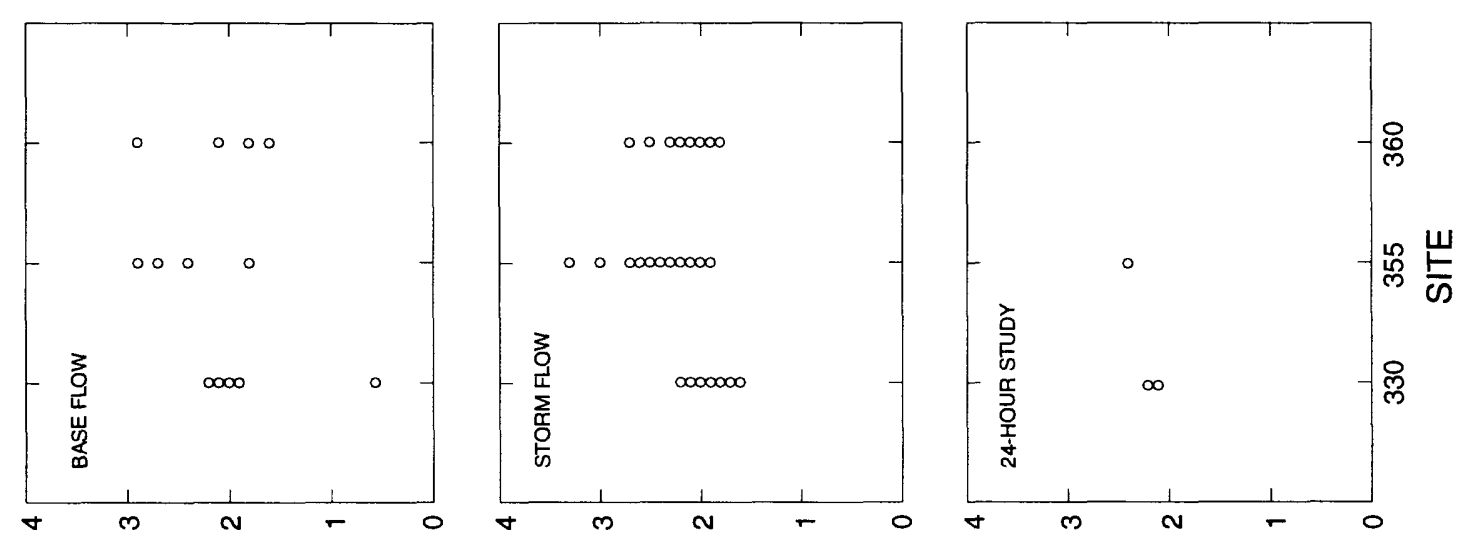

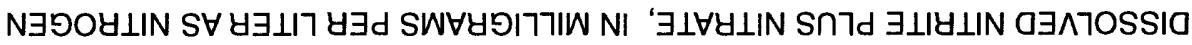



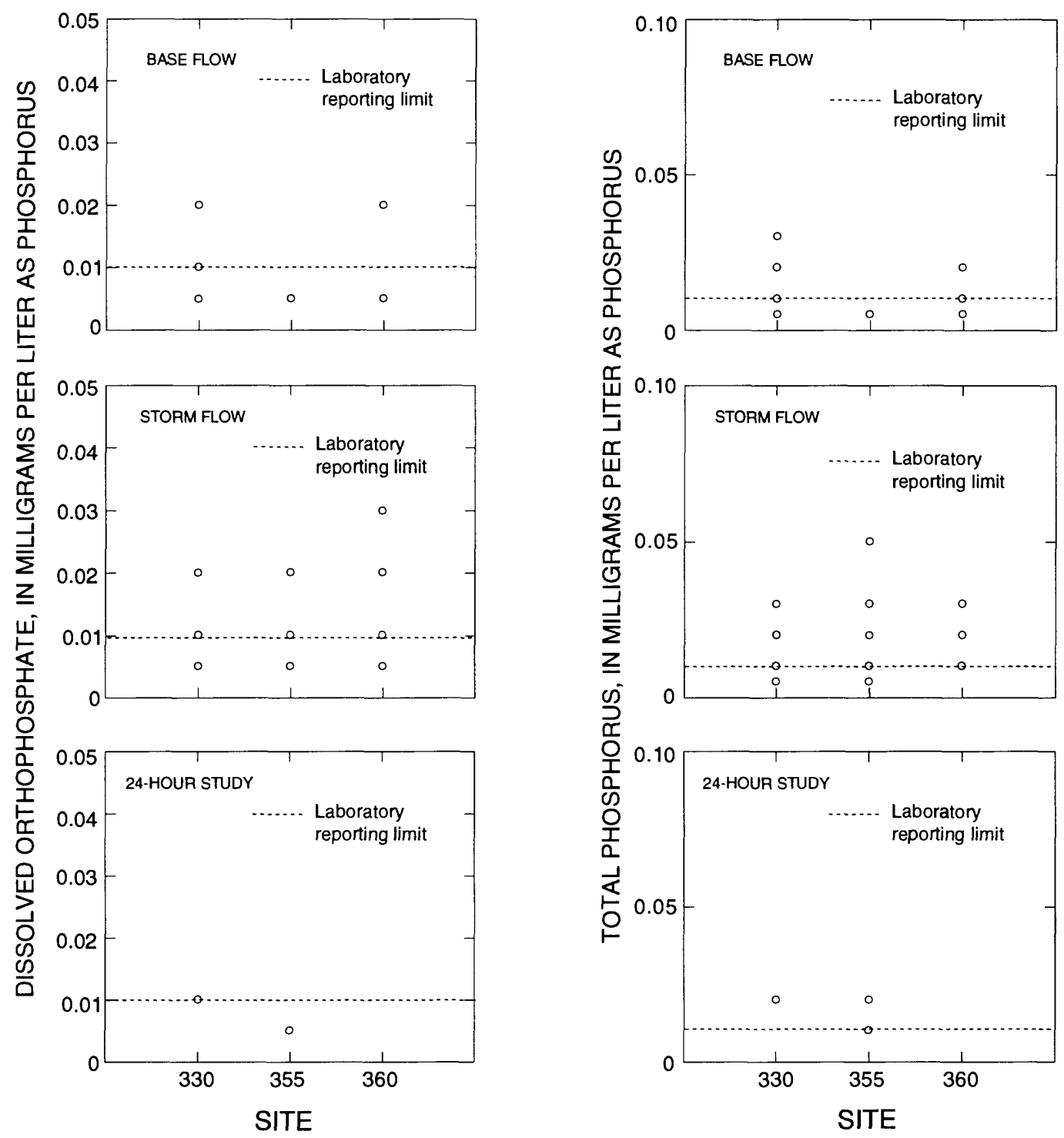

Figure 9.--Concentrations of dissolved orthophosphate and total phosphorus at three sites in the Upper Clover Creek subbasin, 1991-92. (Data reported as less than the laboratory reporting limit have been arbitrarily assigned a value of one half that limit.) 

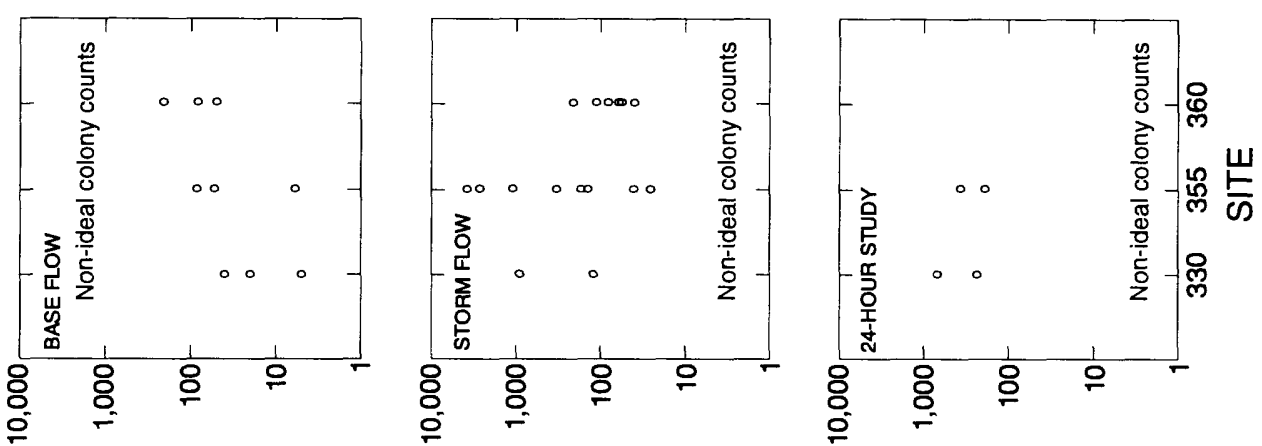

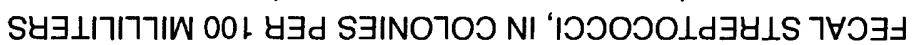
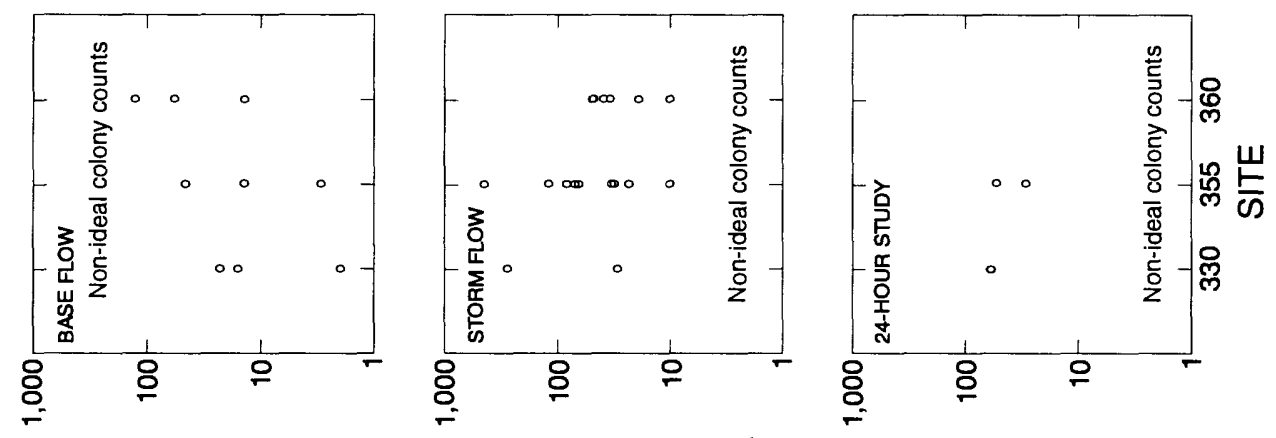

S4ヨコIרIרIW 00เ
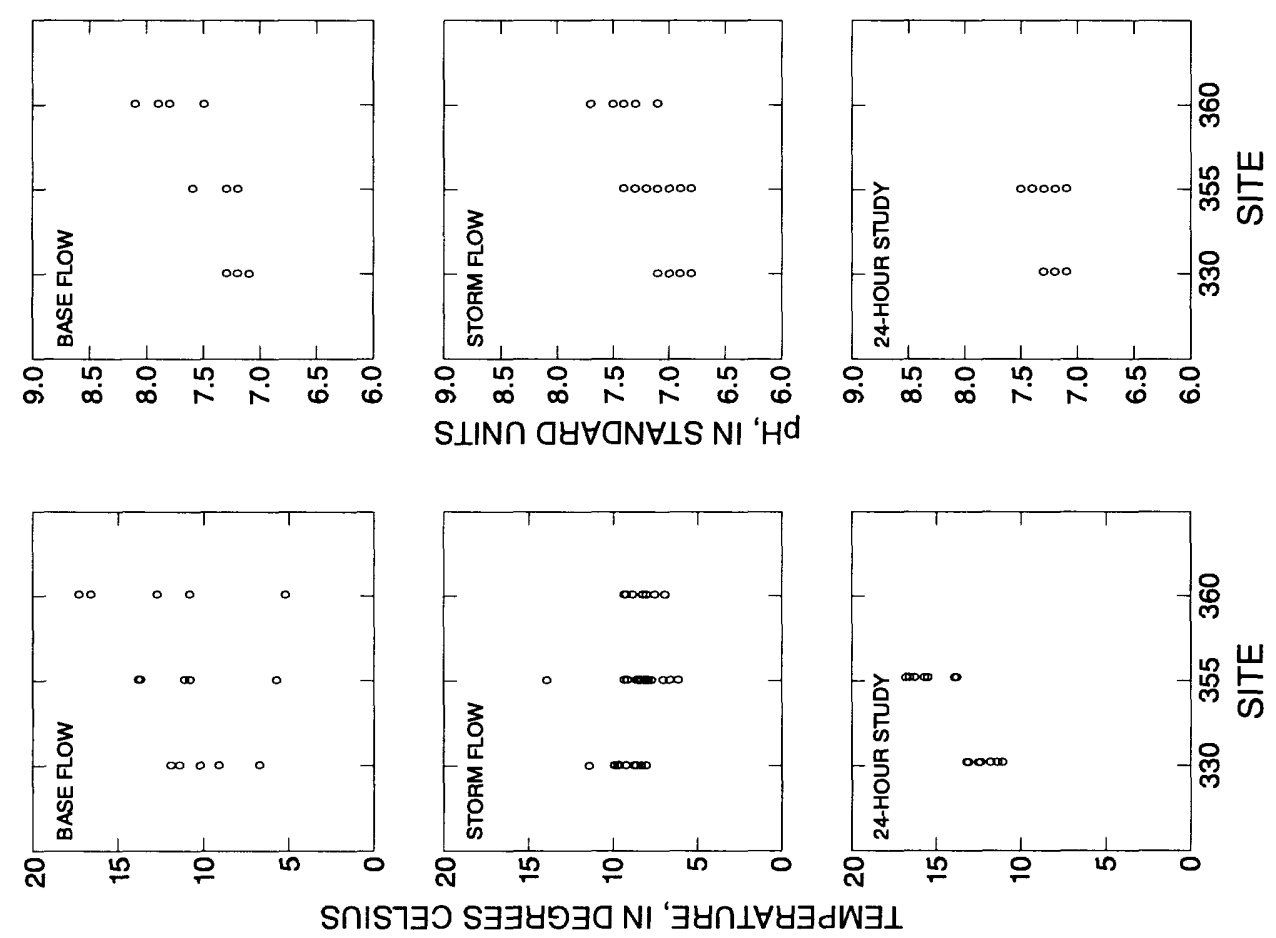

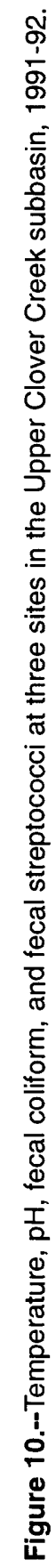


Table 4.--Observed range of total-recoverable metal concentrations in the Clover Creek Basin, 1991-92

[Number in parentheses indicates the total number of samples analyzed; <, less than]

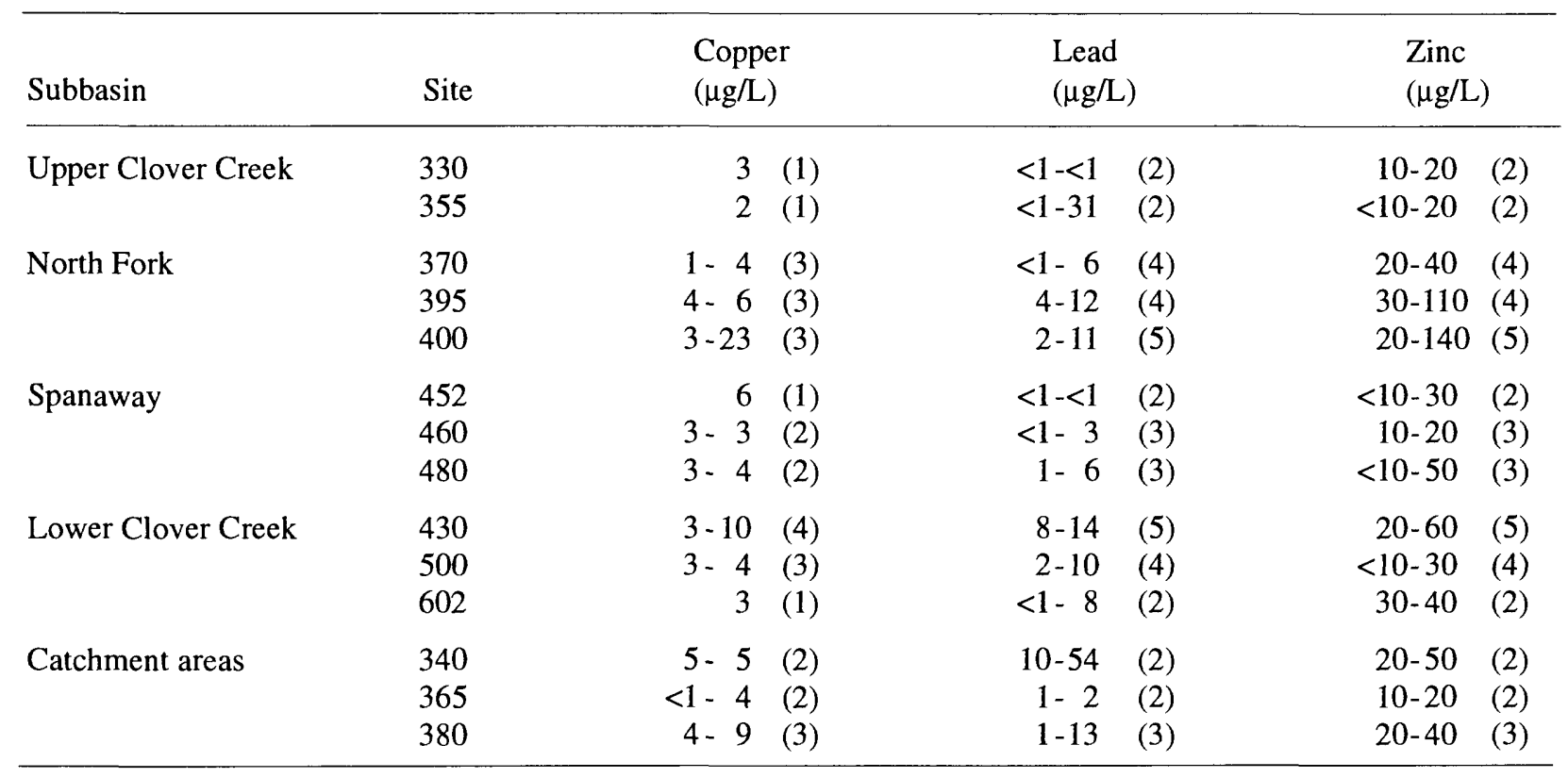

At site 355, the next site downstream from site 330, somewhat different stream-discharge and water-quality characteristics were observed. For example, discharge data (fig. 7) show that flow increases appreciably at site 355 during storms. The lower values of specific conductance and chloride (fig. 7) measured during these highflow periods indicate dilution by a source other than ground water. Because of the high (hourly) frequency of data collection, discharge and specific conductance data from the automated monitor located at site 355 (fig. 11) show this trend more clearly than the data collected manually (fig. 7): rapid, short-term rises in the discharge hydrograph correlate well with sharp drops in specific conductance. Although the period of record is short, the data also suggest the presence of a longer-term seasonal trend: conductance is slightly more diluted in the winter months, when precipitation rates are higher, than during the drier summer months. These differences between storm- and base-flow conditions indicate that, in addition to ground-water discharge, streamflow at site 355 includes a surface or shallow subsurface runoff component during rainfall. Increased runoff from impervious surfaces is to be expected in this area because of the greater urbanization that occurs downstream of site 330 . Surface or shallow subsurface runoff is also expected from the area northeast of site 355 , which is underlain by low-permeability glacial-till deposits. Increases in suspended sediment (fig. 7), dissolved orthophosphate and total phosphorus (fig. 9), and fecal streptococci (fig. 10) levels that occur during rainfall also indicate that storm-flow discharge at site 355 includes a substantial surface-runoff component.

Even under base-flow conditions, discharge at site 355 is considerably higher and dissolved nitrite plus nitrate concentrations are slightly elevated relative to site 330. The increased discharge is likely due to a combination of additional ground-water discharge along the stream reach between the two sites and inflow from an unnamed tributary that enters Clover Creek between sites 330 and 355 (fig. 6). Inflow from this tributary is also a likely source of additional dissolved nitrite plus nitrate because it drains an unsewered residential area underlain by relatively impermeable glacial till materials.

The elevated summer temperatures recorded at site 355 (figs. 10 and 11) can be attributed to the pooling of water in the vicinity of the site. This pooling reduces the stream velocity and allows the water temperature to approach equilibrium with the warmer, overlying air. These higher water temperatures promote biological growth and the associated processes of photosynthesis and respiration. Because these processes are influenced by sunlight and temperature, they have a pronounced diurnal cycle, which explains the periodic fluctuations in $\mathrm{pH}$ (fig. 12) and the broad range of dissolved-oxygen concentrations observed during the September 1991, 24-hour study (fig. 13). 
Discharge data show that in the lower part of the subbasin, Clover Creek changes from a ground-water discharge area to a ground-water recharge area and the elevated discharges observed at site 355 dissipate before reaching site 360 (fig. 7). Downstream from site 360, channel losses continue, and discharge in this part of the stream often ceases completely during the summer months. Although discharges differ considerably, waterquality characteristics are generally similar between sites 355 and 360 . However, the creek passes through a marshy area just upstream of site 360 . The long residence time and high productivity of water in this marsh lead to a broader range of water temperatures and elevated $\mathrm{pH}$ at site 360 (fig. 10).

Table 5.--Elemental composition of fine-grained (less than 63 micrometers in diameter) streambed-sediment materials in the Clover Creek Basin, 1991-92

$[\mu \mathrm{g} / \mathrm{g}$, micrograms per gram; $<$, less than]

\begin{tabular}{|c|c|c|c|c|}
\hline Element $^{1}$ & Site 330 & Site 480 & Site 500 & Site 602 \\
\hline Aluminum (percent) & 3.1 & 3.7 & 3.9 & 3.4 \\
\hline Barium $(\mu \mathrm{g} / \mathrm{g})$ & 190 & 210 & 240 & 190 \\
\hline Calcium (percent) & 1.9 & 1.7 & 1.5 & 1.4 \\
\hline Cerium $(\mu \mathrm{g} / \mathrm{g})$ & 9 & 14 & 17 & 12 \\
\hline Chromium $(\mu \mathrm{g} / \mathrm{g})$ & 65 & 58 & 70 & 58 \\
\hline Cobalt $(\mu \mathrm{g} / \mathrm{g})$ & 5 & 7 & 9 & 7 \\
\hline Copper $(\mu \mathrm{g} / \mathrm{g})$ & 25 & 94 & 60 & 53 \\
\hline Gallium $(\mu \mathrm{g} / \mathrm{g})$ & 6 & 8 & 8 & 6 \\
\hline Iron (percent) & 1.1 & 1.9 & 1.8 & 1.4 \\
\hline Lanthanum $(\mu \mathrm{g} / \mathrm{g})$ & 7 & 9 & 11 & 9 \\
\hline Lead $(\mu \mathrm{g} / \mathrm{g})$ & 23 & 90 & 170 & 180 \\
\hline Lithium $(\mu \mathrm{g} / \mathrm{g})$ & 10 & 16 & 13 & 11 \\
\hline Magnesium (percent) & 0.53 & 0.61 & 0.61 & 0.56 \\
\hline Manganese $(\mu \mathrm{g} / \mathrm{g})$ & 310 & 650 & 440 & 330 \\
\hline Molybdenum $(\mu \mathrm{g} / \mathrm{g})$ & $<2$ & $<2$ & 3 & 3 \\
\hline Neodymium $(\mu \mathrm{g} / \mathrm{g})$ & 8 & 9 & 12 & 9 \\
\hline Nickel $(\mu \mathrm{g} / \mathrm{g})$ & 19 & 23 & 31 & 26 \\
\hline Phosphorus (percent) & 0.12 & 0.19 & 0.19 & 0.17 \\
\hline Potassium (percent) & 0.37 & 0.42 & 0.43 & 0.40 \\
\hline Scandium $(\mu \mathrm{g} / \mathrm{g})$ & 5 & 7 & 8 & 6 \\
\hline Silver $(\mu \mathrm{g} / \mathrm{g})$ & $<4$ & $<4$ & 6 & $<4$ \\
\hline Sodium (percent) & 0.88 & 0.91 & 0.86 & 0.73 \\
\hline Strontium $(\mu \mathrm{g} / \mathrm{g})$ & 170 & 170 & 170 & 140 \\
\hline Titanium (percent) & 0.17 & 0.22 & 0.23 & 0.18 \\
\hline Vanadium $(\mu \mathrm{g} / \mathrm{g})$ & 46 & 52 & 57 & 44 \\
\hline Yttrium $(\mu \mathrm{g} / \mathrm{g})$ & 8 & 10 & 12 & 11 \\
\hline Zinc $(\mu \mathrm{g} / \mathrm{g})$ & 59 & 610 & 210 & 190 \\
\hline
\end{tabular}

${ }^{1}$ Observations at all sites were below the laboratory reporting limit for arsenic, beryllium, bismuth, cadmium, europium, gold, holmium, niobium, tantalum, thorium, tin, and uranium. 


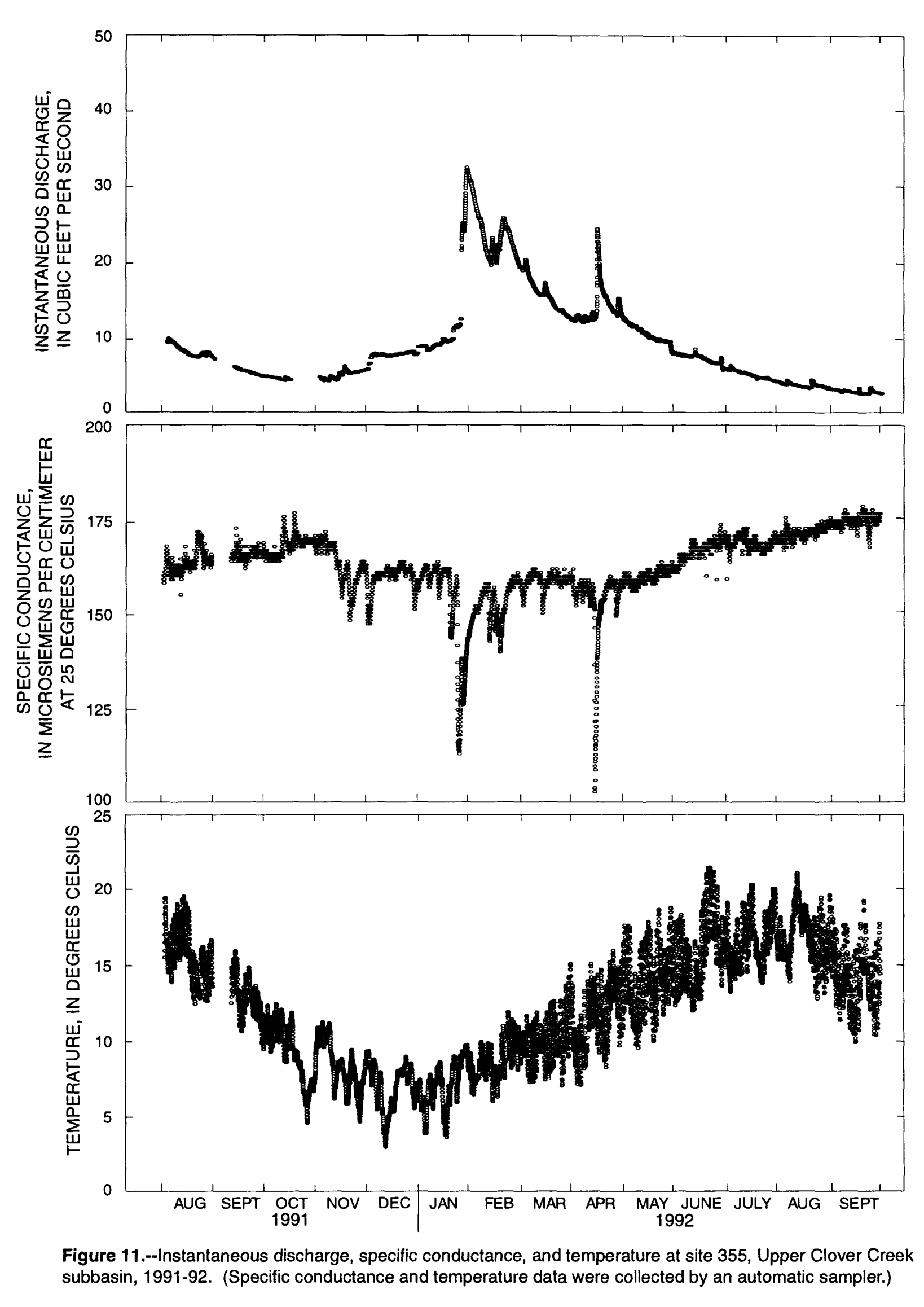




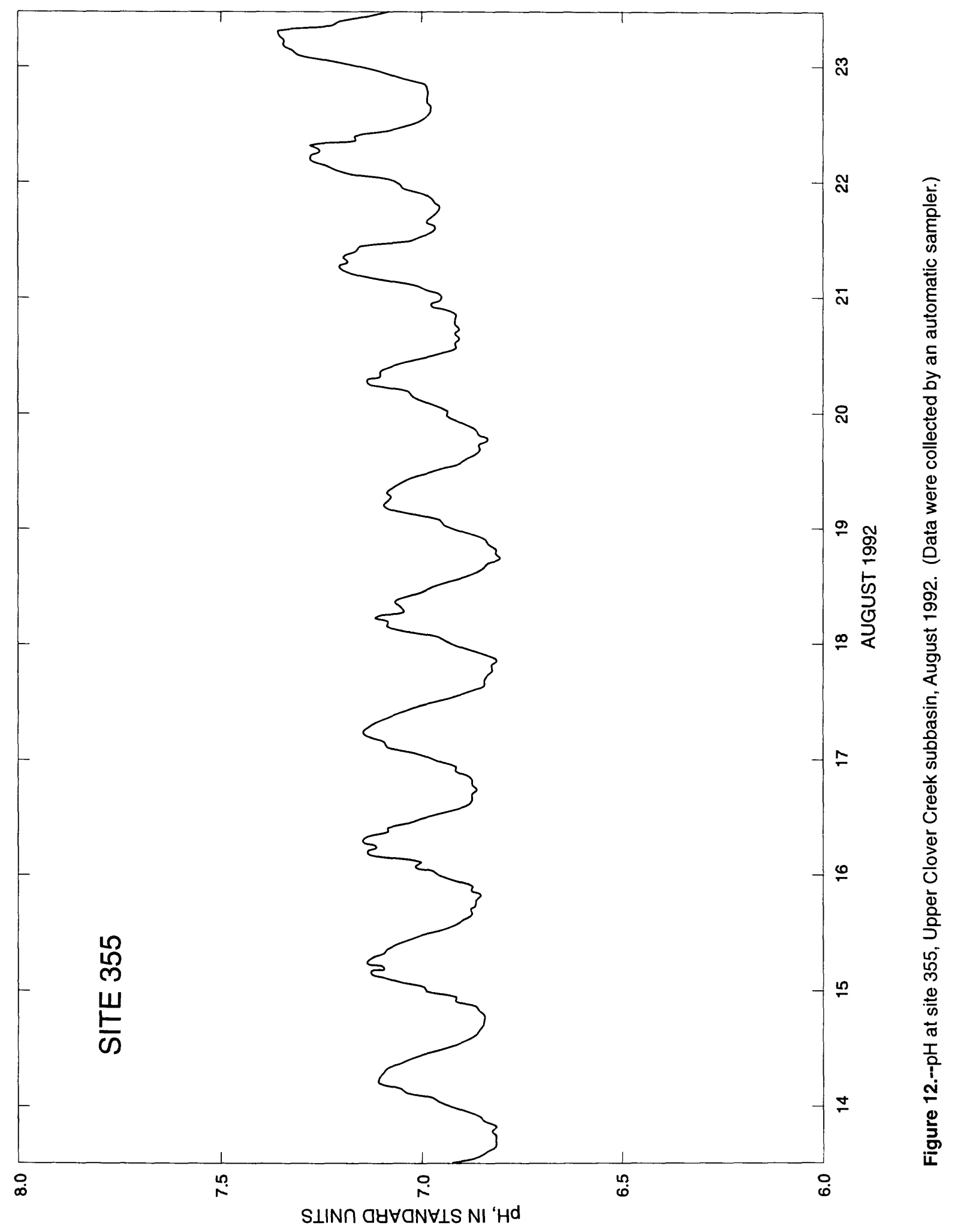



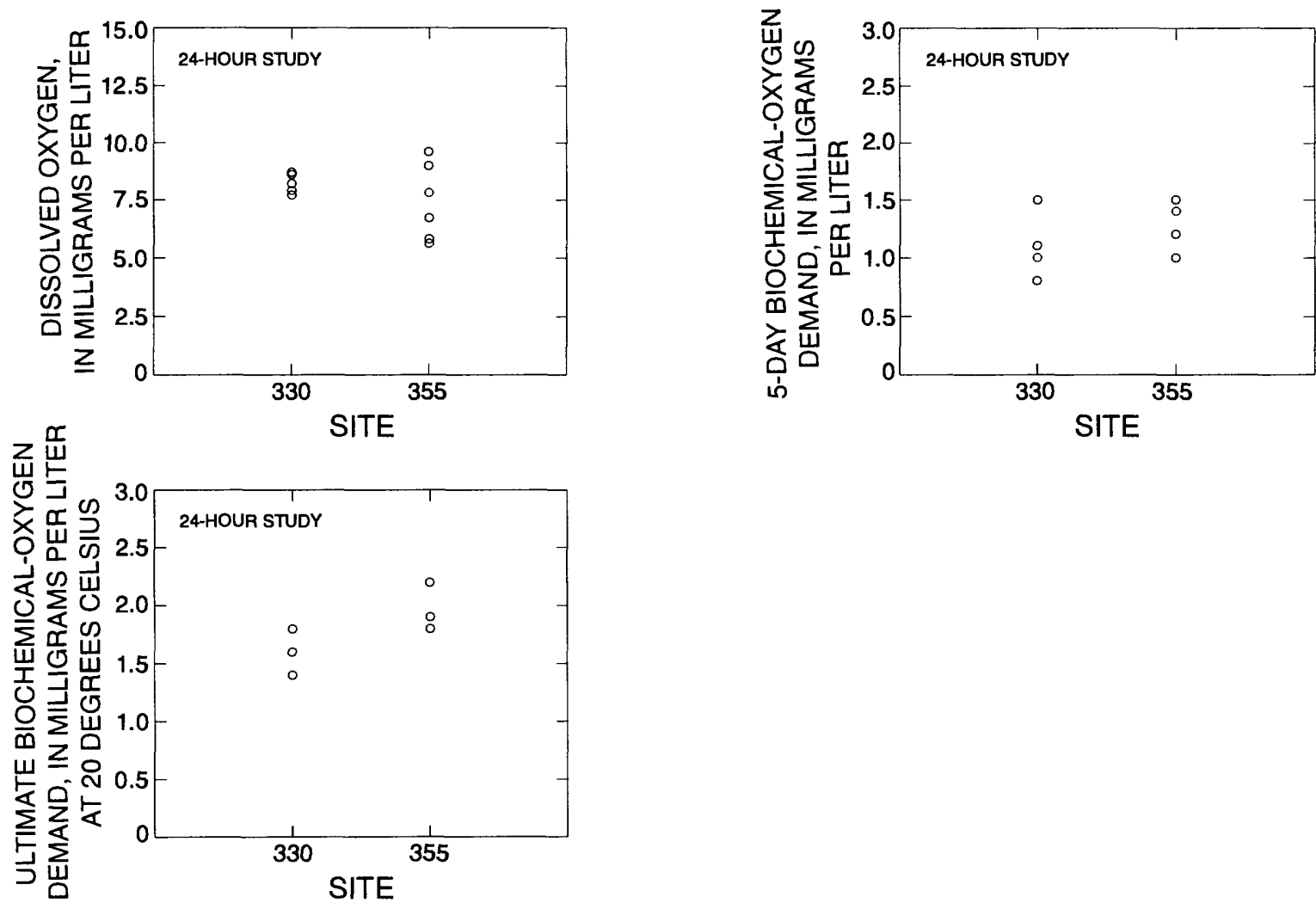

Figure 13.--Dissolved oxygen, 5-day biochemical-oxygen demand, and ultimate biochemical-oxygen demand at two sites in the Upper Clover Creek subbasin, 1991-92.

Finally, water-quality data collected during the current study were compared with available historical data in order to assess long-term trends in the subbasin. During the 1960's and 1970's, water-quality data were collected by the Washington State Department of Ecology (Ecology) (Littler, Aden, and Johnson, 1981) at site 300, located just upstream of current site 355 (fig. 6). Graphical comparisons between these historical data and data collected during the current study are presented for those constituents for which comparable data sets are available (fig. 14). Chloride concentrations have changed substantially; current levels are approximately twice as high as those measured in the early 1960's. Specific conductance has also increased approximately twofold, and intermediate data from the 1970's suggest the increase has been gradual. Both total and dissolved phosphorus concentrations have decreased, probably due to their reduced use in soap products. Total ammonia plus organic nitrogen concentrations have also decreased somewhat, but the reason for this is not clear. 
닐 또
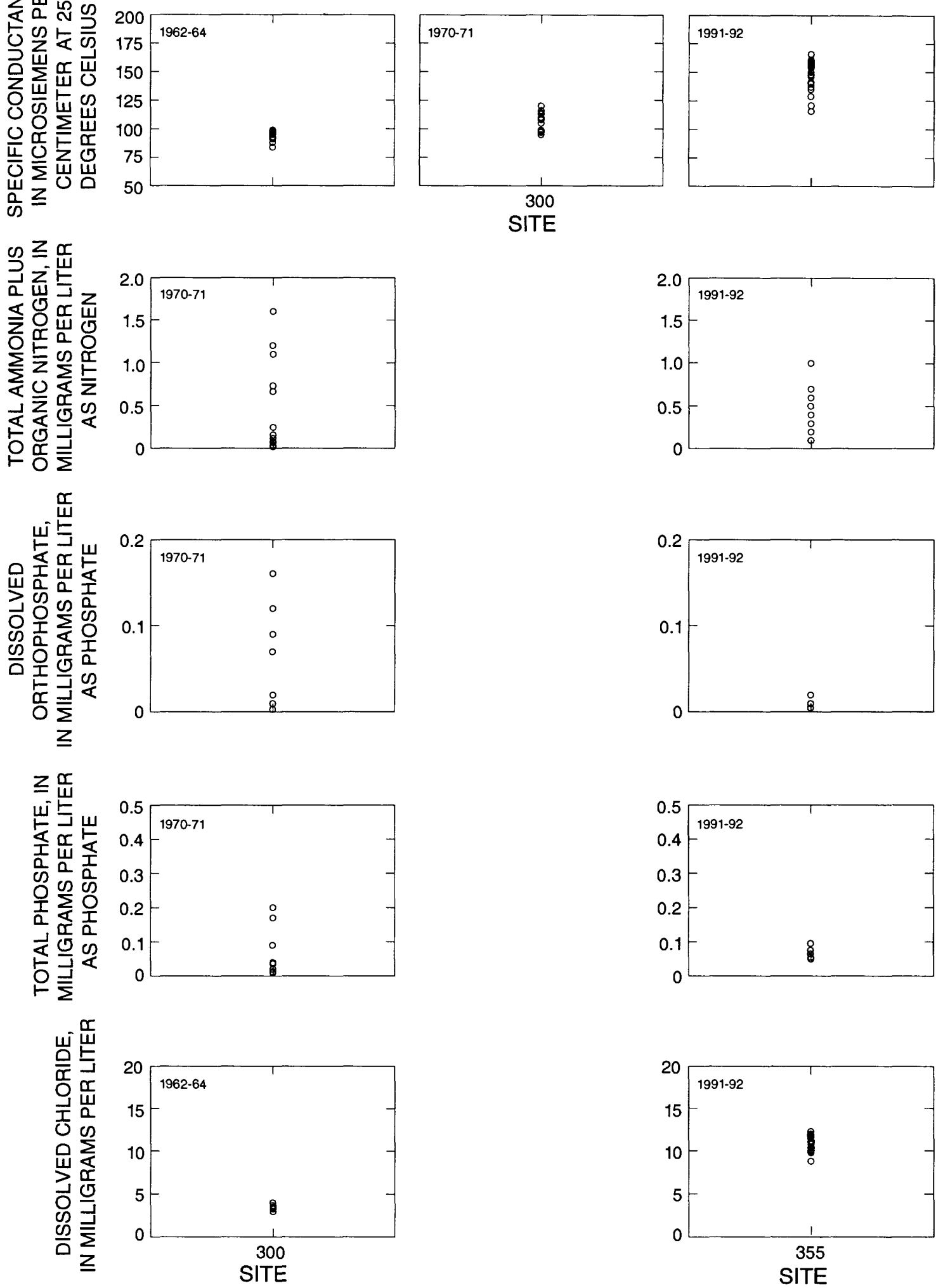

Figure 14.--Specific conductance and concentrations of total ammonia plus organic nitrogen, dissolved orthophosphate, total phosphate, and dissolved chloride at site 300, 1962-64 and 1970-71, and at site 355, 1991-92, Upper Clover Creek subbasin. 


\section{Spanaway Subbasin--Sites 452, 460, and 480 .}

As in the Upper Clover Creek subbasin, no large temporal variations in water quality or stream discharge were seen in the Spanaway subbasin. In this subbasin, however, these effects can be attributed to the presence of Spanaway and Tule Lakes rather than to the effects of ground water. Lakes can have a significant effect on water quality because of settling of suspended materials, mixing of dissolved constituents, and biological activity, as indicated by the data collected from the Spanaway subbasin.

Although stream discharge in the subbasin increases in response to rainfall (fig. 15), changes are generally moderate because of the attenuating effects of the lakes. The largest changes in discharge were seen at site 452, located at the outflow of Spanaway Lake (fig. 6), and may be partially due to discharge from several stormwater outfalls located upstream of the site (fig. 5). The smallest variations in discharge were observed at site 480 , located on Morey Creek, and this behavior can be attributed to the distributary itself, which was designed to divert a relatively uniform discharge from Spanaway Creek.

The tight distribution of specific conductance values measured over the course of the study (fig. 15) illustrates the hydraulic effects of the lakes. Short-term, small-scale fluctuations were not observed because of the long residence time in the lakes, which allows adequate time for the dispersion process to attenuate concentration peaks. The hydraulic effects of the lakes are also illustrated by the behavior of chloride (fig. 15). With the exception of three anomalously high concentrations, two at site 452 and one at site 480 , chloride concentrations were very stable over the course of the study. The effect of reduced water velocity on suspended materials is also reflected in the data.

Concentrations of suspended sediment were consistently less than $20 \mathrm{mg} / \mathrm{L}$ and at the two lake outlets did not exceed $5 \mathrm{mg} / \mathrm{L}$ (fig. 15).

Nutrient concentrations were generally moderate, and no distinction was clear between base- and storm-flow conditions (figs. 16 and 17). Concentrations measured during the 24-hour study conducted in September 1991, however, were low relative to those observed throughout most of the year. These lower concentrations may be attributed to utilization of available nutrients resulting from increased biological activity during the warm summer months and to decreased mobilization of nutrients resulting from low-flow conditions.

The variations in $\mathrm{pH}$ observed in this subbasin, particularly at sites 452 and 460 , were due to the biological processes of photosynthesis and respiration (fig. 18). This is particularly clear from data collected during the 24-hour study, which show a diurnal range of approximately 1.5
$\mathrm{pH}$ units. An additional, indirect indicator of biological activity is the level of biochemical oxygen demand measured during the 24-hour study (fig. 19). These levels, which were elevated relative to those measured at other sites in the basin, were likely the result of an abundance of organic material in the form of biomass or its degradation products. Although the oxygen demand at these sites was high, concentrations of dissolved oxygen measured during the same period indicate that oxygen was replenished at a rate sufficient to prevent depletion.

The moderate levels of fecal coliform and fecal streptococci observed in the subbasin (fig. 18) are probably due to the prolonged residence time of water in Spanaway and Tule Lakes. The concentrated areas of land development around the lakes (fig. 4) are very likely sources of considerable numbers of fecal bacteria. However, because these organisms have limited survival outside of the digestive tracts of warm-blooded animals, few of those that enter the lakes would be likely to survive for the time necessary to travel to the lake outlets.

Copper, lead, and zinc concentrations measured in whole water samples (table 4) were lower than most of those measured during the USEPA's Nationwide Urban Runoff Program (U.S. Environmental Protection Agency, 1983). Again, these concentrations can be attributed to the presence of the lakes. Most of the metals that enter the lakes from surrounding urbanized areas are likely bound to suspended solids and removed from the water column by settling. In contrast, bed-sediment data collected at site 480 show elevated concentrations of copper, lead, manganese, and zinc (table 5). With the exception of manganese, these concentrations exceed those found in 95 percent of western United States soils (Severson, Wilson, and McNeal, 1987). Copper, lead, and zinc are commonly associated with transportation activities and urbanization, and the concentrations observed suggest that such anthropogenic sources are likely. The presence of Spanaway Lake may also partially account for the elevated concentrations at this particular site. A substantial part of lacustrine sediments results from decayed microorganisms, and the humic materials that form from these sediments are efficient at binding metals. Sediments in this subbasin may therefore act as particularly effective scavengers of metals.

Site 480 was also the only site within the study area at which any of the selected organic compounds were detected (Appendix A, table A6). In August of 1991, tetrachloroethylene was detected at this site at a concentration of $0.3 \mu \mathrm{g} / \mathrm{L}$ (micrograms per liter; this is below the $5.0 \mu \mathrm{g} / \mathrm{L}$ maximum contaminant level set by USEPA for the compound). During additional sampling in January and March of 1992, however, no organic compounds were detected at this site. 

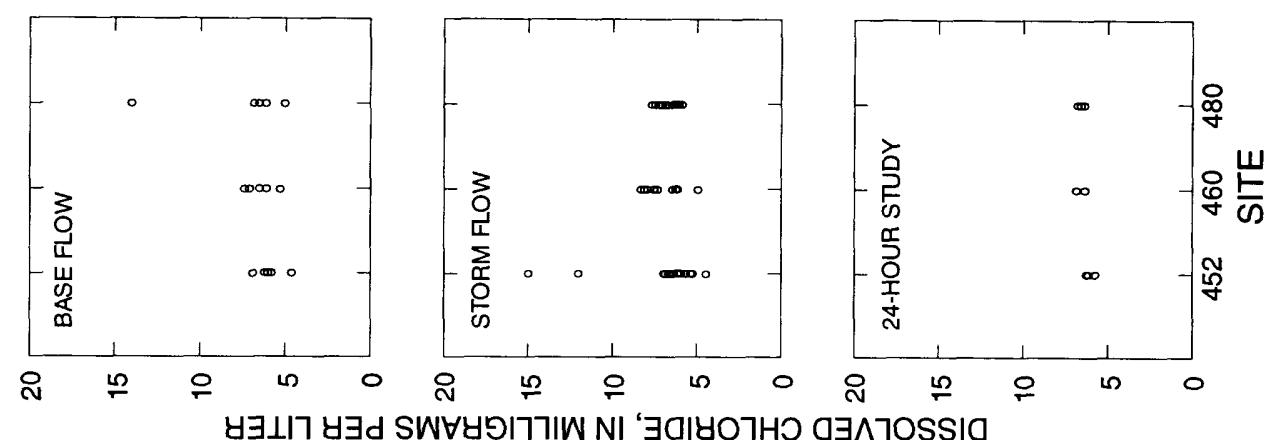

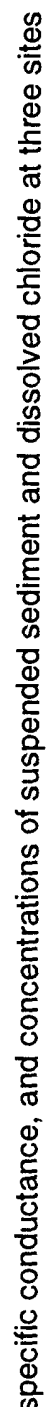
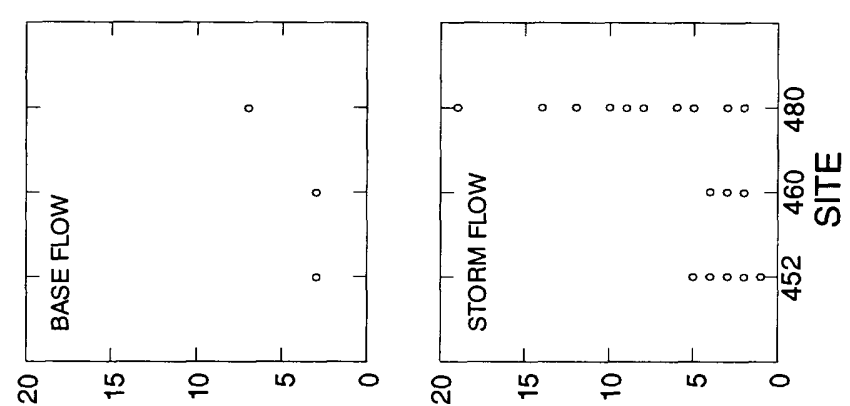

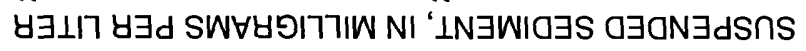
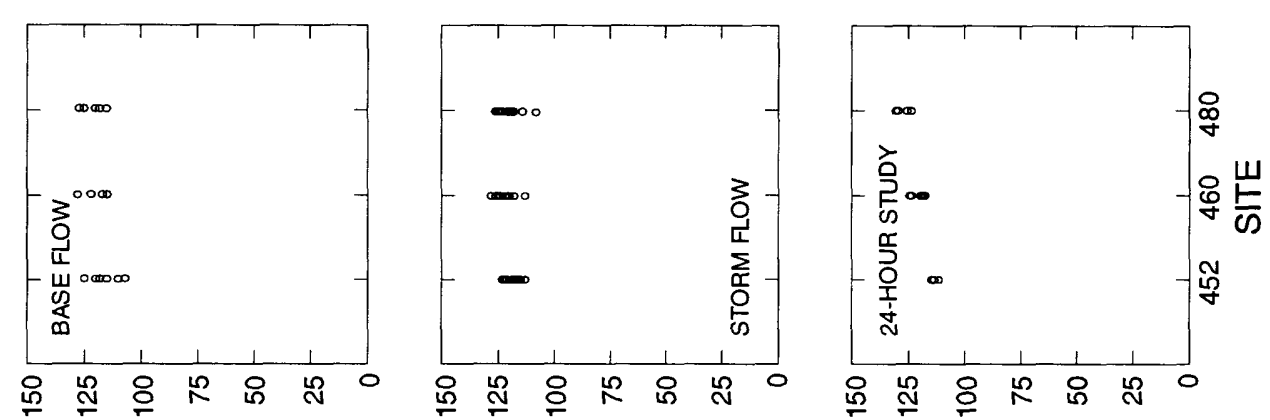

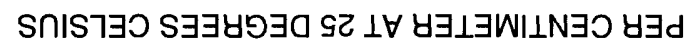

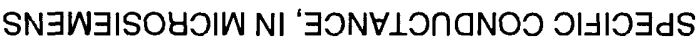
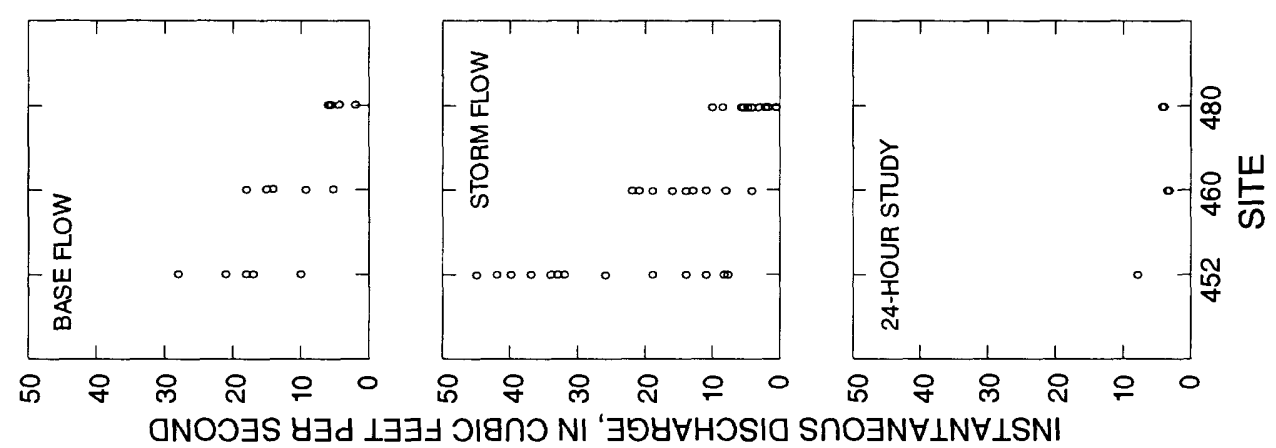

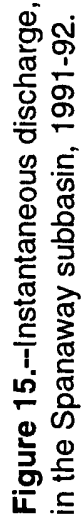



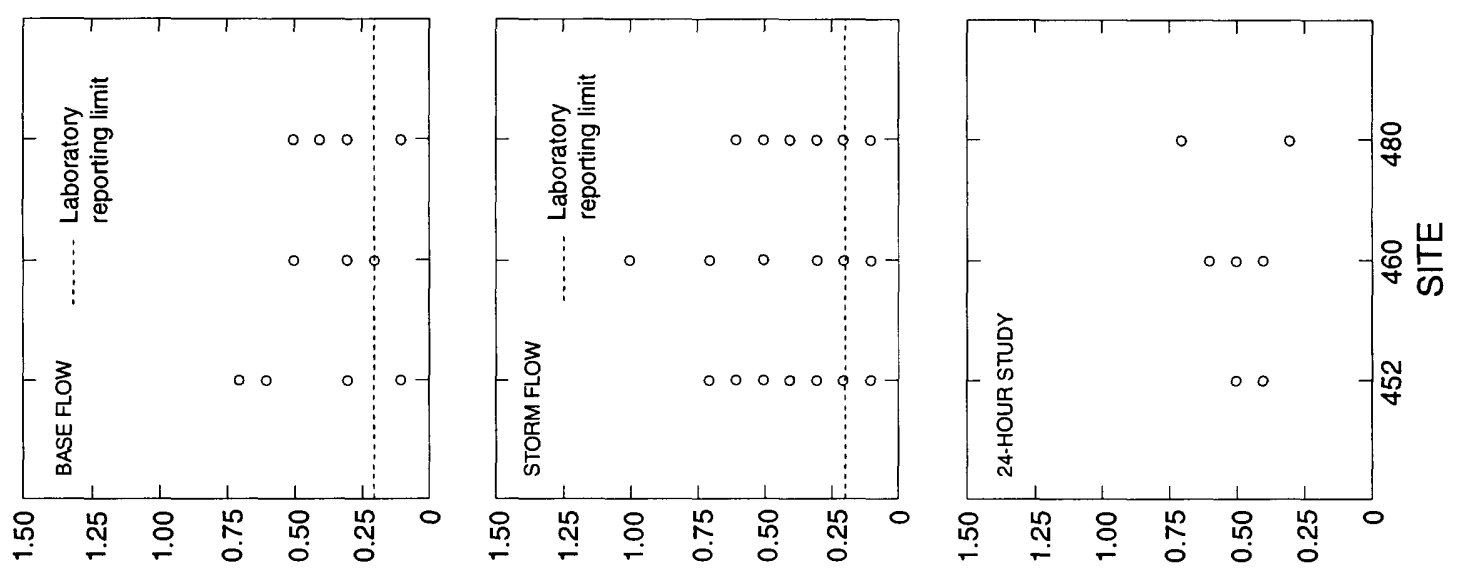

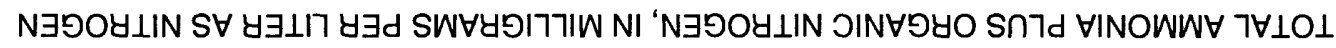
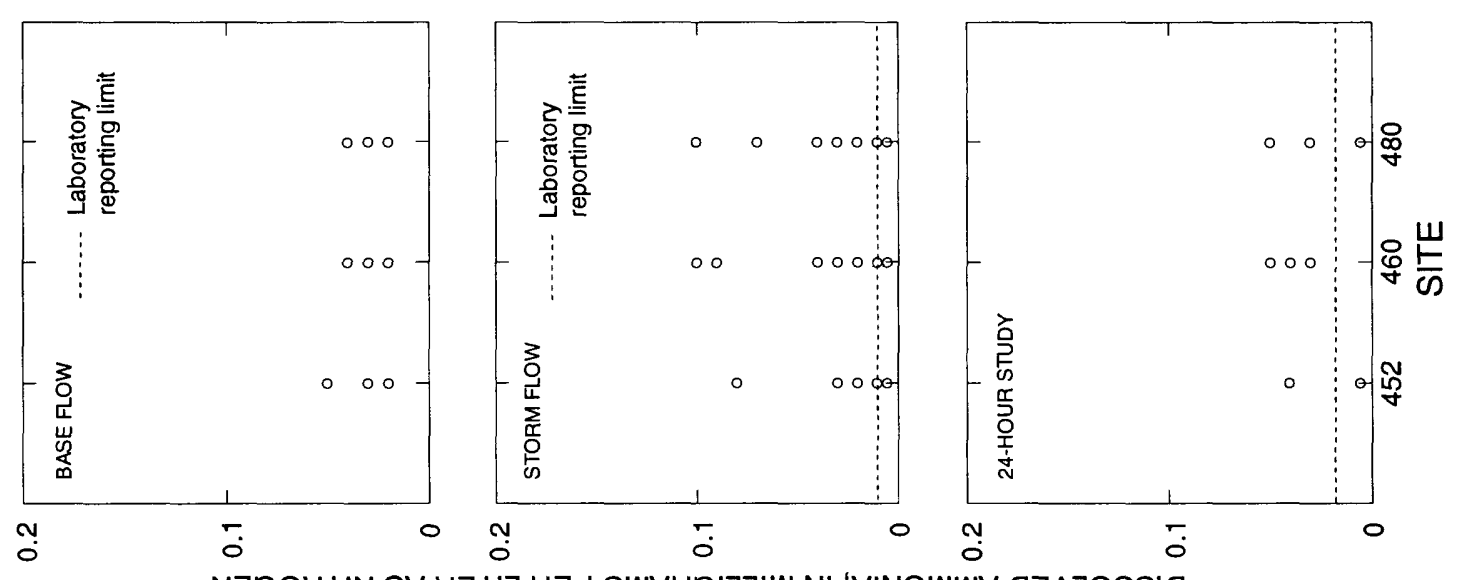

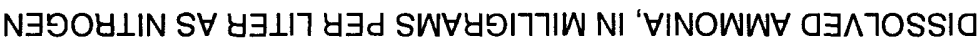
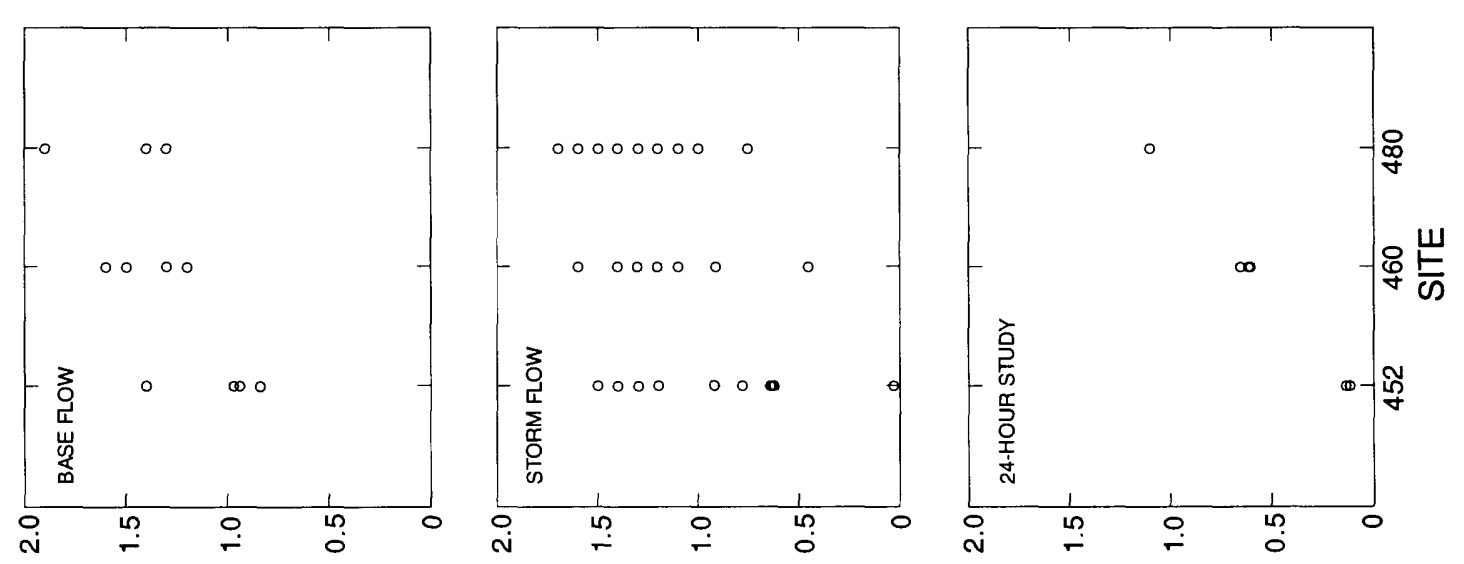

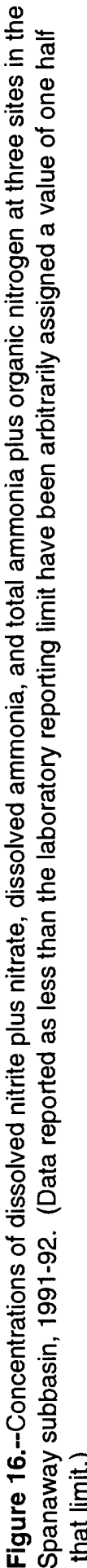

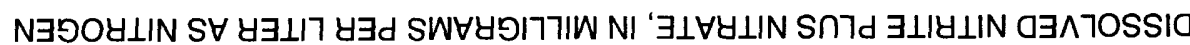



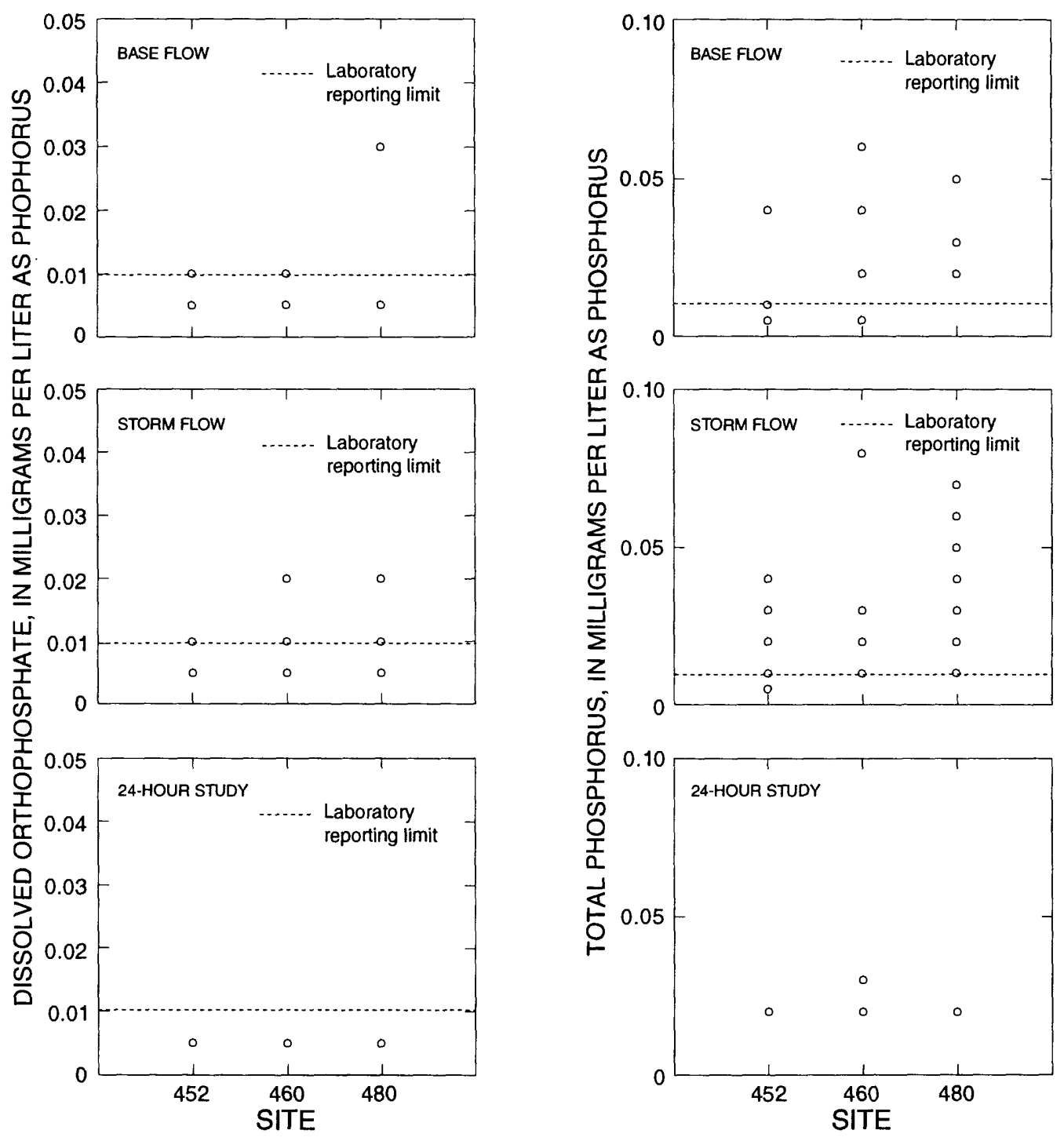

Figure 17.--Concentrations of dissolved orthophosphate and total phosphorus at three sites in the Spanaway subbasin, 1991-92. (Data reported as less than the laboratory reporting limit have been arbitrarily assigned a value of one half that limit.) 

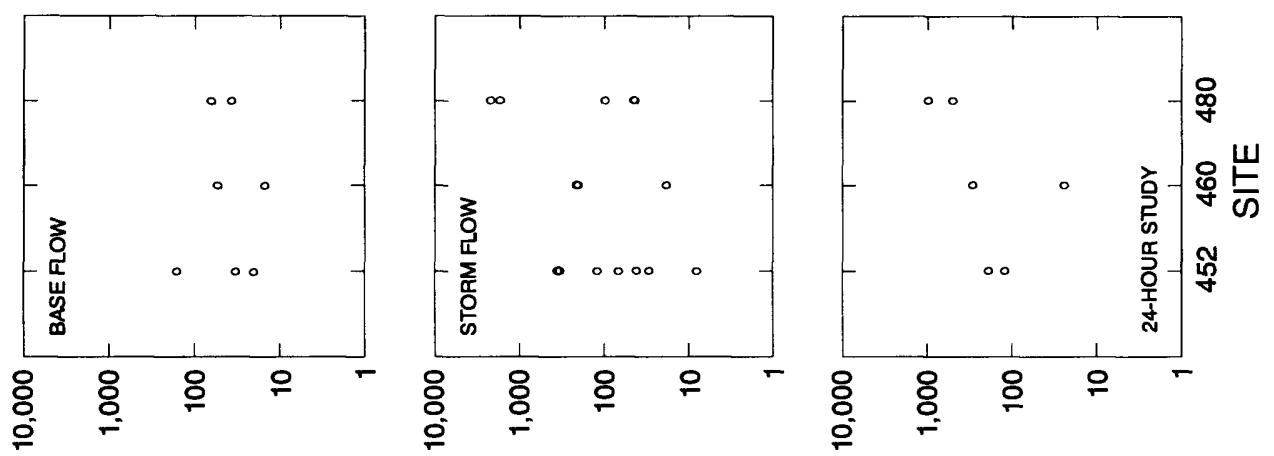

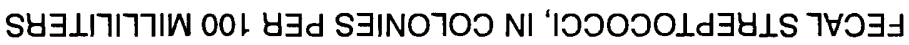
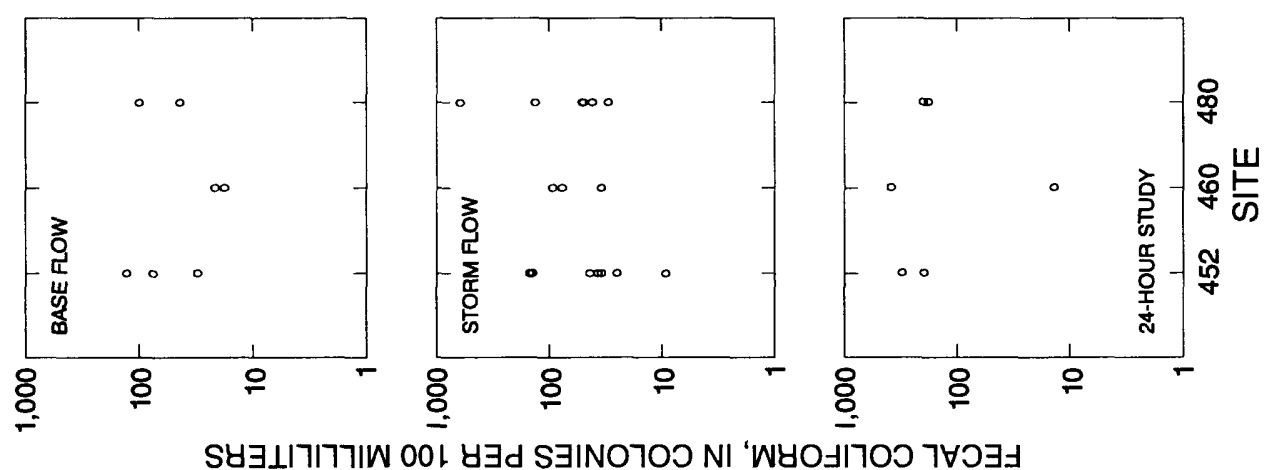

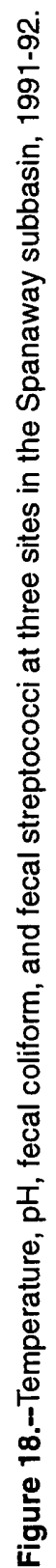
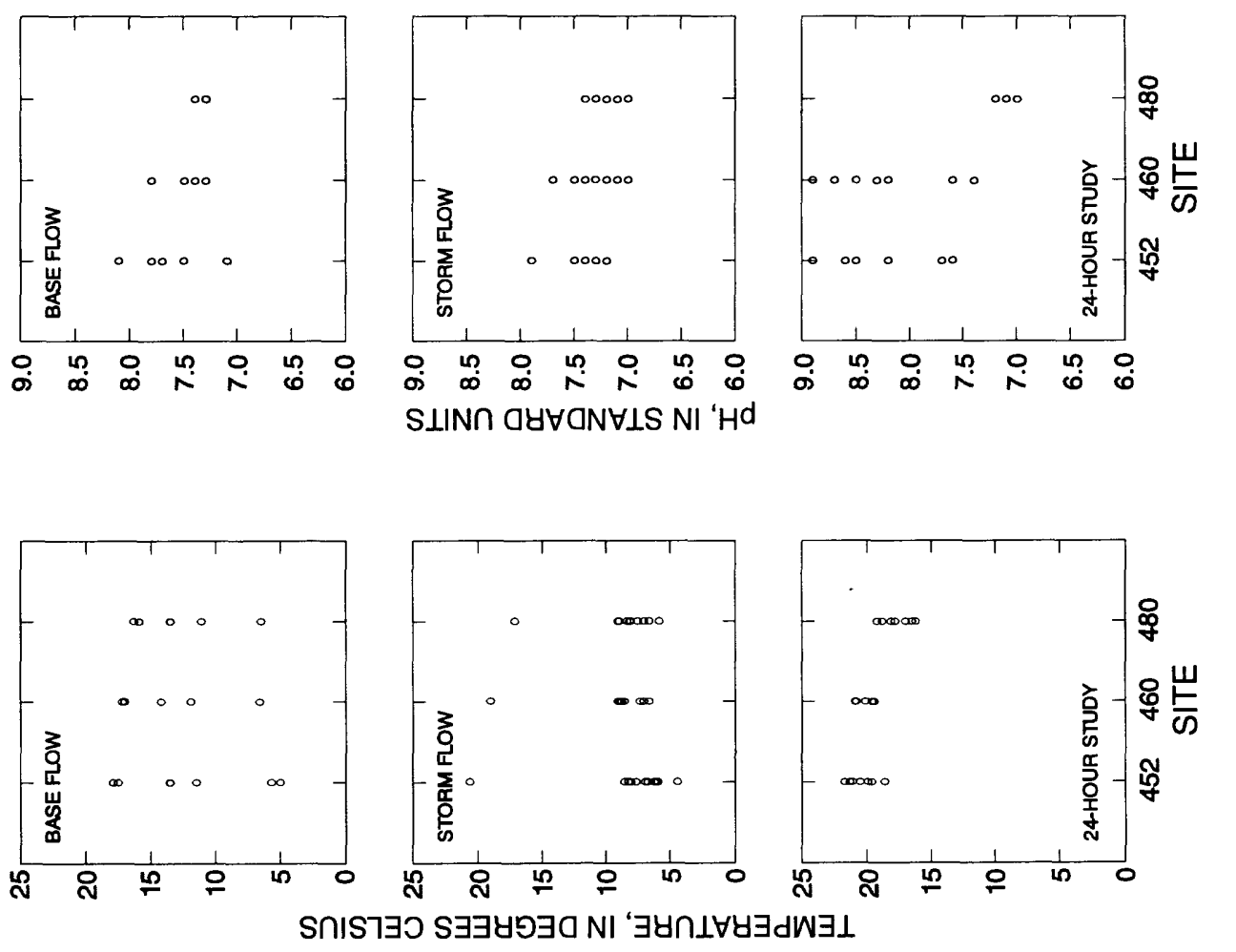

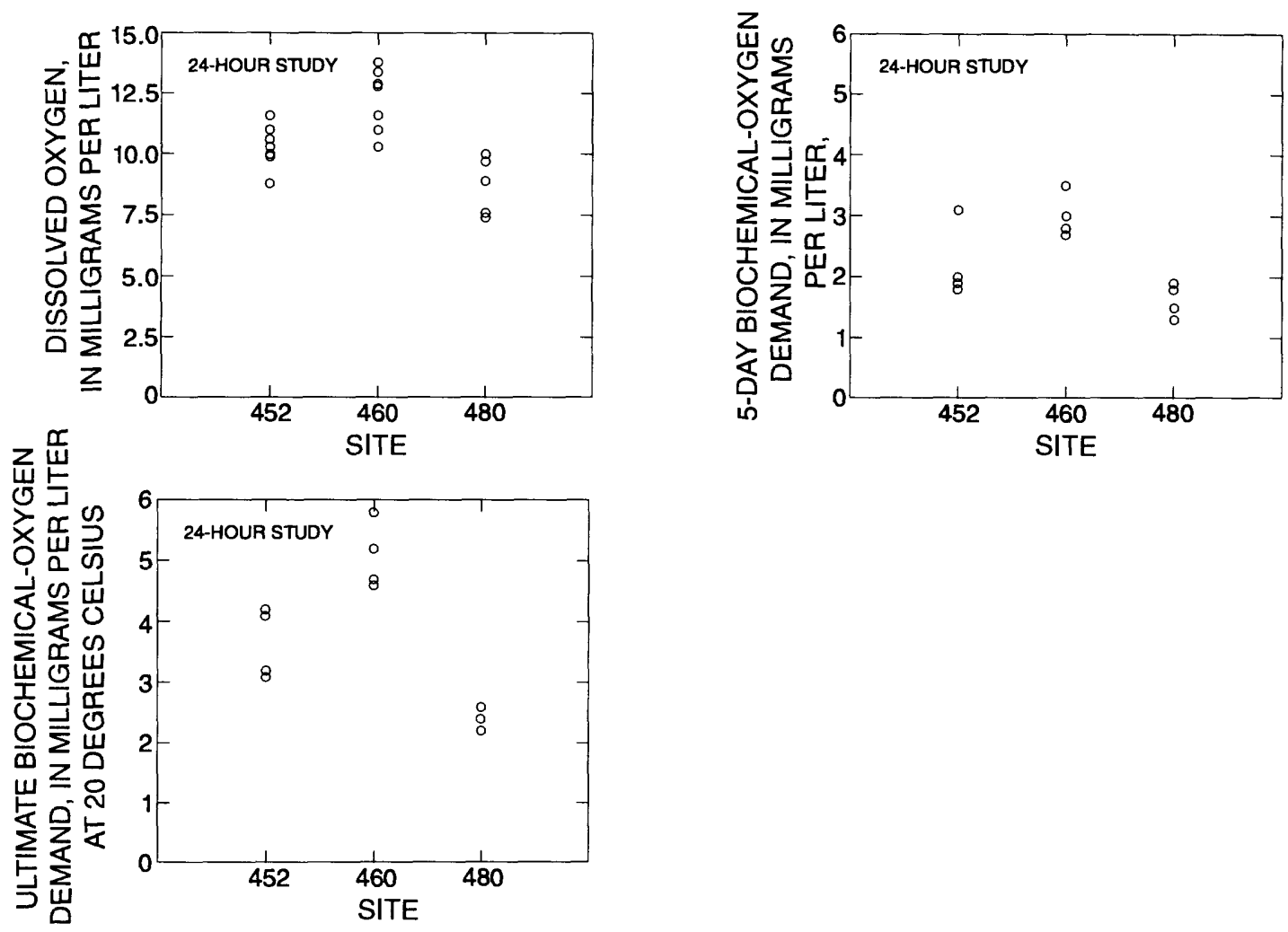

Figure 19.--Dissolved oxygen, 5-day biochemical-oxygen demand, and ultimate biochemical-oxygen demand at three sites in the Spanaway subbasin, 1991-92.

\section{North Fork Subbasin--Sites 370, 395, and 400}

In contrast to the subbasins discussed thus far, large differences in stream discharge and water quality occur between base- and storm-flow conditions in the North Fork subbasin. These differences are due primarily to the presence of the low-permeability glacial till that underlies most of the subbasin (fig. 3). Because infiltration to ground water does not occur readily through the glacial till, storm runoff follows more rapid, direct surface or shallow subsurface routes to stream channels. This results in substantial increases in stream discharge in response to storms (fig. 20). Suspended sediment, ammonia, total ammonia plus organic nitrogen, phosphorus, fecal coliform, and fecal streptococci levels also increase during storms, indicating that these species result largely from the wash off of surface accumulations (figs. 20-23).
Whereas stream discharge and the concentrations of many water-quality constituents increase in response to rainfall, specific conductance and $\mathrm{pH}$ decrease (figs. 20 and 23), indicating dilution by rainfall and short residence times in the subbasin. Precipitation is typically low in specific conductance and $\mathrm{pH}$, and increases in these properties result from biological or chemical transformations along flow paths. Because of the relatively rapid, direct flow paths typical of storm runoff in this subbasin, adequate time is not available for these processes to significantly alter the composition of runoff. The effects of short flow paths are more evident at site 395 than at site 370 , indicating that the impervious surfaces associated with the densely developed area drained by Maple Creek have an even stronger effect than the glacial till in the more rural eastern part of the subbasin. The effects of these two parts of the subbasin are integrated at site 400 . 
The similarity in chloride concentrations observed during base- and storm-flow conditions (fig. 20) suggests contributions from both surface and subsurface sources. However, although the data are not frequent enough to show a clear, consistent relation between stream discharge and chloride concentration, they show that both the highest and lowest concentrations were observed during storms. This type of behavior commonly occurs when highly soluble compounds resulting from urban activities accumulate on impervious surfaces. Rainfall quickly dissolves such compounds, transporting them to receiving streams as short-term pulses followed by more dilute flow.

Dissolved nitrite plus nitrate also displayed different behavior patterns in the different parts of the subbasin (fig. 21). Concentrations were relatively low at site 370 under base-flow conditions, but increased in response to storms. In contrast, at site 395 dissolved nitrite plus nitrate concentrations remained relatively high during both base- and storm-flow conditions. This consistency at site 395 suggests that a long-term, subsurface source of nitrogen is available. Such a supply of nitrogen could result from on-site waste-disposal systems or from the regular application of fertilizers over an extended period. Both of these are likely sources in this part of the subbasin. Although a part of the area is now served by the ULID, much of the population continues to rely on on-site disposal methods. Furthermore, abandoned on-site wastedisposal systems still act as long-term sources of nitrogen and other compounds.

The two parts of the subbasin also show differences in suspended-sediment concentrations (fig. 20). With the exception of two particularly high concentrations measured at site 370 , increases in suspended-sediment concentrations associated with storms were generally greater at site 395 than at site 370 . This was likely due to erosion that resulted from alterations in the stream channel and from disturbance of the riparian vegetation along Maple Creek during the study period.

Further evidence of the effects of the greater urbanization in the part of the subbasin drained by Maple Creek is provided by the metals data (table 4). Concentrations of copper, lead, and zinc measured at site 370 were low in comparison to those measured at site 395 . In fact, the highest zinc concentrations measured over the course of the study occurred at sites 395 and 400 , and the highest copper concentration was observed at site 400 . These elevated concentrations, which included metals associated with solid-phase materials, occurred at the same times as high suspended-sediment loads at both sites. These data indicate not only that urban activities in the northern and western parts of the subbasin are a source of metals to the stream, but also that the suspended-sediment load resulting from channel erosion and wash off from impervious surfaces enhances the downstream transport of these metals.

\section{Lower Clover Creek Subbasin-- Sites 430, 500, and 602}

Discharges from the three subbasins discussed thus far flow into the Lower Clover Creek subbasin. The most upstream site in the Lower Clover Creek subbasin, site 430, receives flow from the Upper Clover Creek and North Fork subbasins and a large number of stormwater outfalls that enter Clover Creek upstream of the site. Sites 500 and 602 are located in the downstream part of the subbasin and, in addition to receiving flow from site 430 , receive flow from the Spanaway subbasin. Water quality at these sites thus reflects an integration of the factors affecting water quality in the more upstream parts of the Clover Creek Basin.

Under base-flow conditions, outflows from the Upper Clover Creek and North Fork subbasins (represented by flows at sites 360 and 400, respectively) are similar in magnitude, and as a result, stream discharge and constituent concentrations at site 430 typically are intermediate between those of the two subbasins (figs. 24-27). During storms, however, increased flow from the North Fork subbasin dominates the discharge and water quality at site 430. This dominance is particularly manifested by increases in discharge, total ammonia plus organic nitrogen, total phosphorus, suspended sediment, fecal coliform, and fecal streptococci, and decreases in specific conductance. Elevated counts of fecal streptococci and low values of $\mathrm{pH}$ observed during storms indicate additional, rapid runoff from impervious surfaces along the reach just upstream of site 430 . This explanation is consistent with the high-density residential and commercial development that characterizes the Lower Clover Creek subbasin (fig. 4) and the large number of stormwater outfalls located along this part of the stream (fig. 5). 

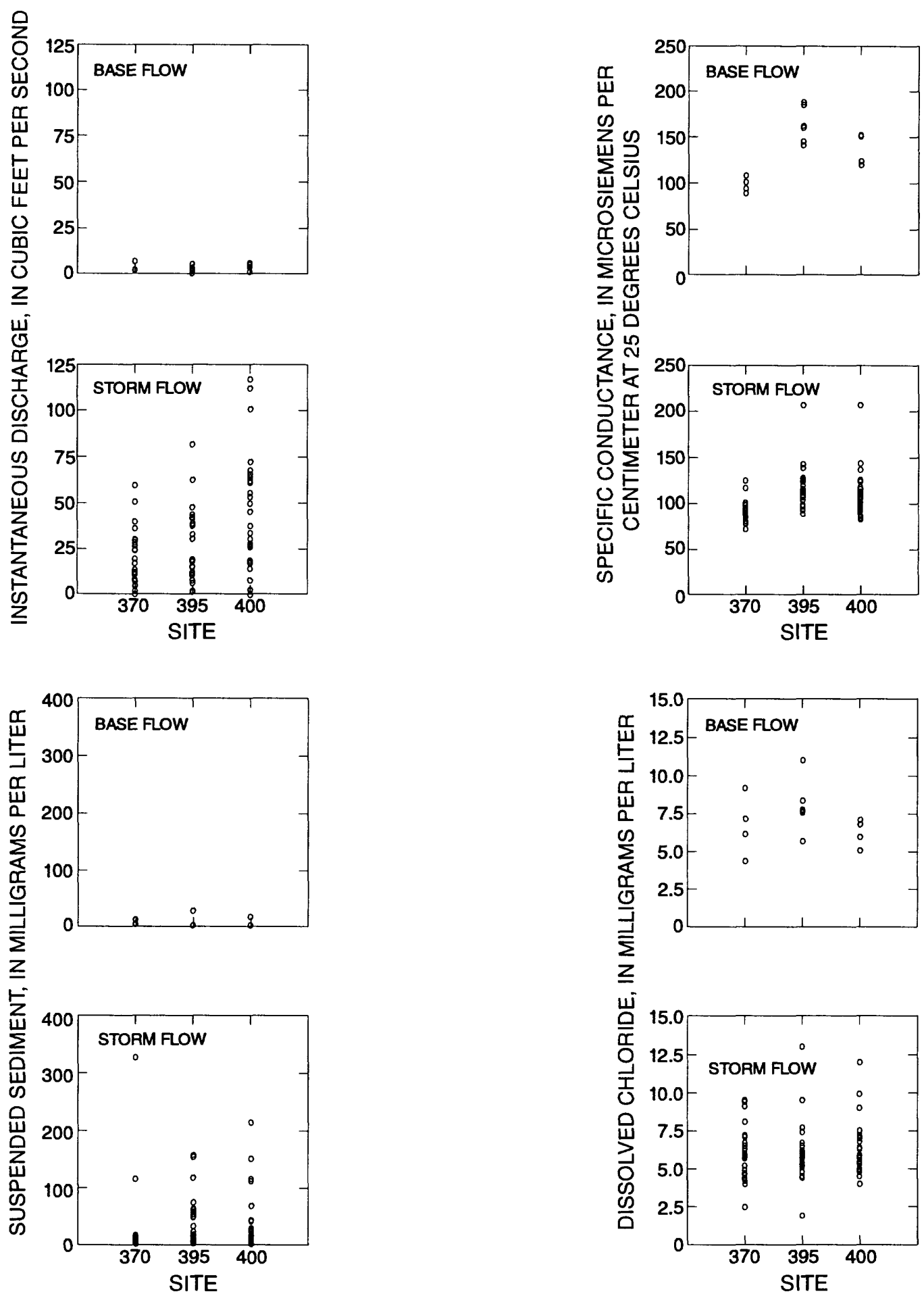

Figure 20.--Instantaneous discharge, specific conductance, and concentrations of suspended sediment and dissolved chloride at three sites in the North Fork subbasin, 1991-92. 

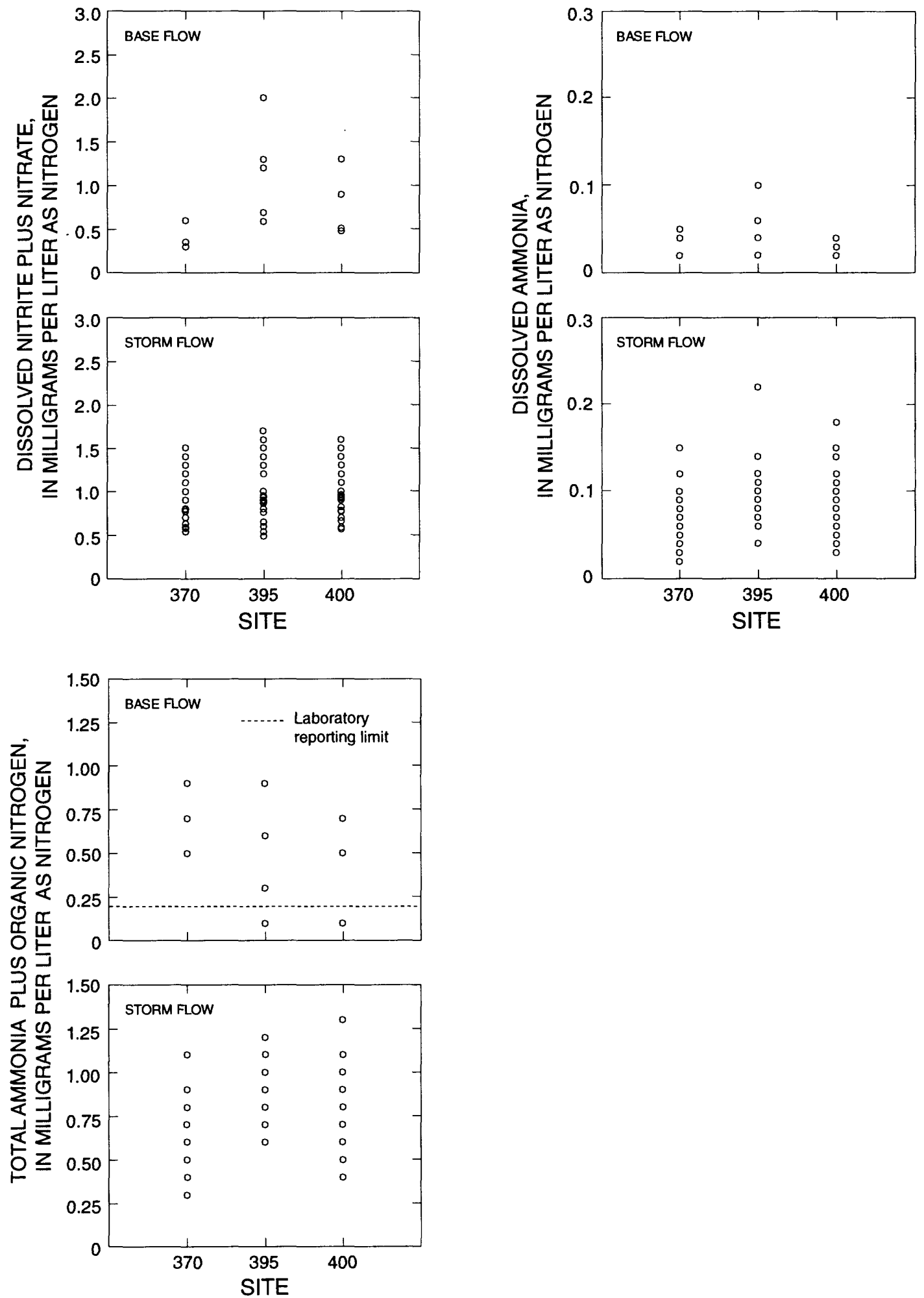

Figure 21.--Concentrations of dissolved nitrite plus nitrate, dissolved ammonia, and total ammonia plus organic nitrogen at three sites in the North Fork subbasin, 1991-92. (Data reported as less than the laboratory reporting limit have been arbitrarily assigned a value of one half that limit.) 

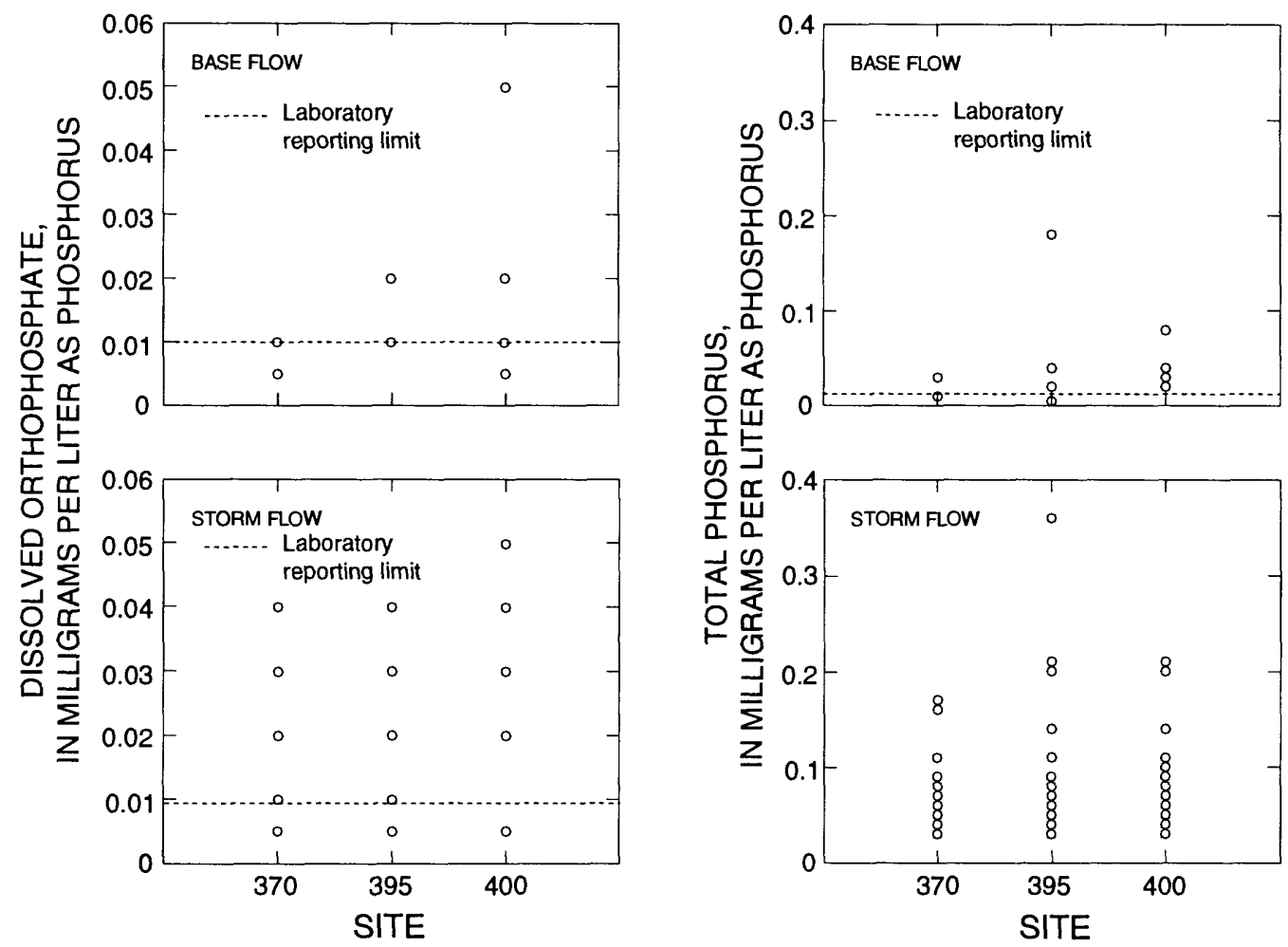

Figure 22.--Concentrations of dissolved orthophosphate and total phosphorus at three sites in the North Fork subbasin, 1991-92. (Data reported as less than the laboratory reporting limit have been arbitrarily assigned a value of one half the limit.)

At site 500 and 602, suspended-sediment (fig. 24), ammonia (fig. 25), and total phosphorus (fig. 26) concentrations during storms were somewhat lower than those observed at site 430 . These lower concentrations may be partly due to the influence of discharge from the Spanaway subbasin, which effectively dilutes these constituents.

Reduced concentrations of suspended sediment and total phosphorus may also be partly attributed to the settling out of suspended materials that results from decreased streamflow velocities just downstream of site 430 . Diurnal fluctuations in $\mathrm{pH}$, shown by data from the automated monitor at site 500 (fig. 28), and the reduction in nutrient concentrations observed during the September 1991, 24-hour study (figs. 25-26) suggest some biological activity and may also be partially attributed to flow from the Spanaway subbasin, where similar behavior was observed. Additional runoff that enters Clover Creek between sites 430 and 500 includes discharge from several stormwater outfalls and runoff from McChord Air Force Base. Because the quality of water from these sources has not been specifically characterized, their influence on the water quality in Clover Creek cannot be quantified. Data from the automated monitor located at site 500, however, show pronounced decreases in specific conductance in response to increased stream discharge (fig. 29). These decreases are likely due to the contribution of fresh rainwater from the extensive impervious areas of the air base. 

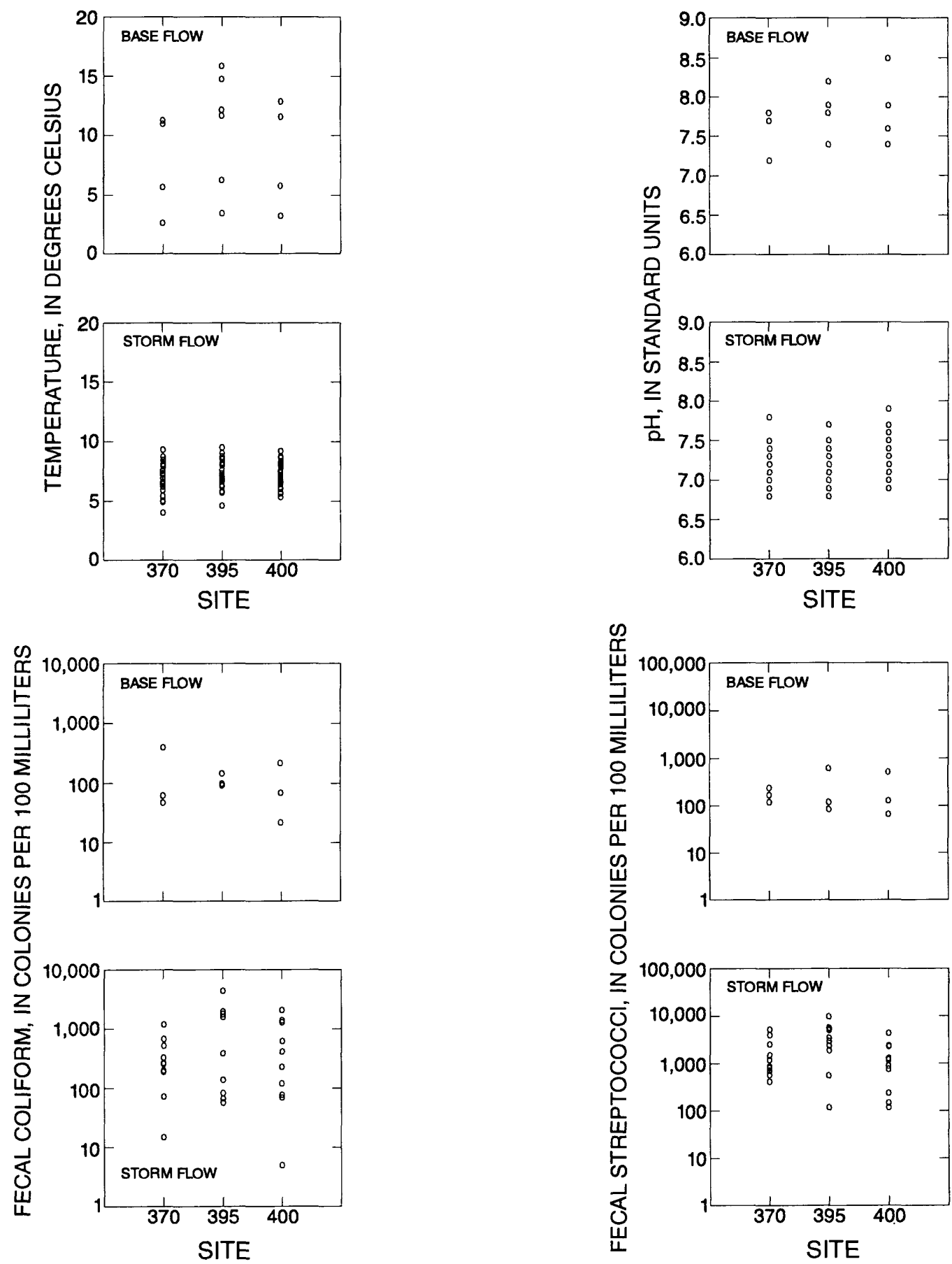

Figure 23.--Temperature, $\mathrm{pH}$, fecal coliform, and fecal streptococci at three sites in the North Fork subbasin, 1991-92. 

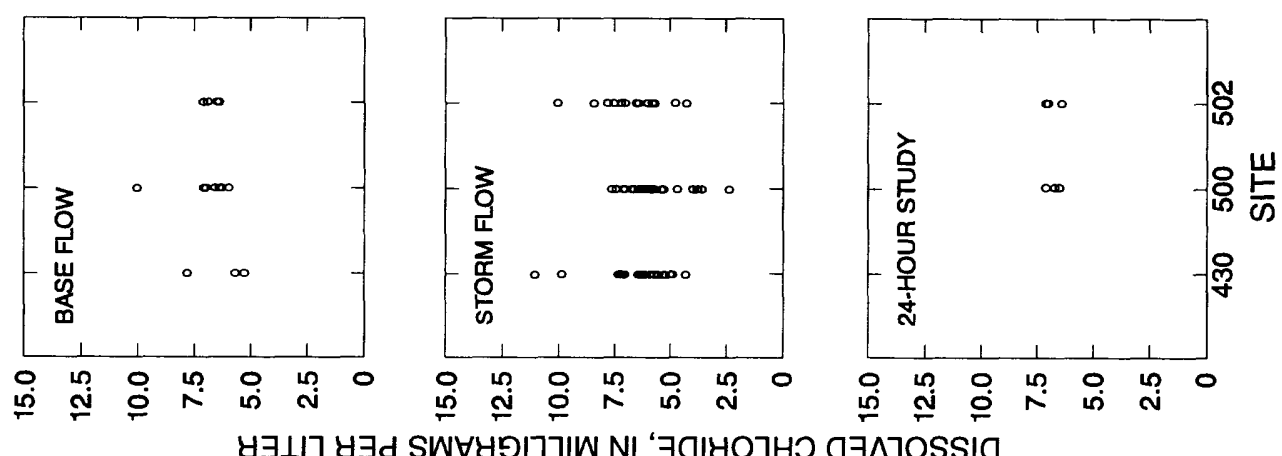

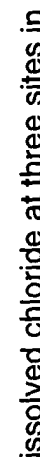
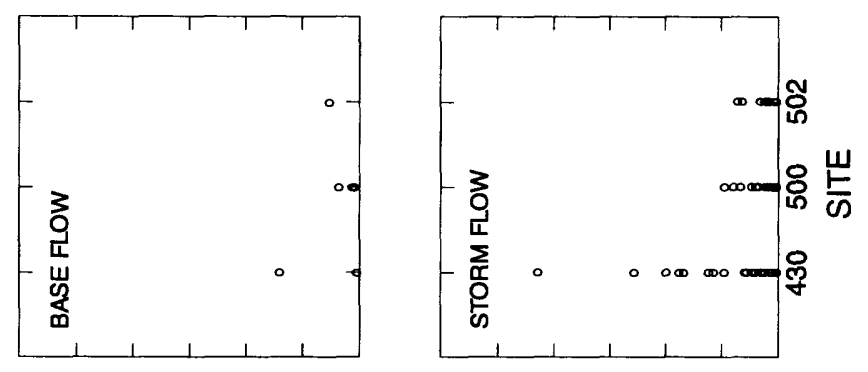

ํำ 은 윤

$\forall \exists \perp 17$ y

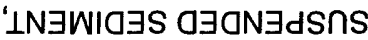
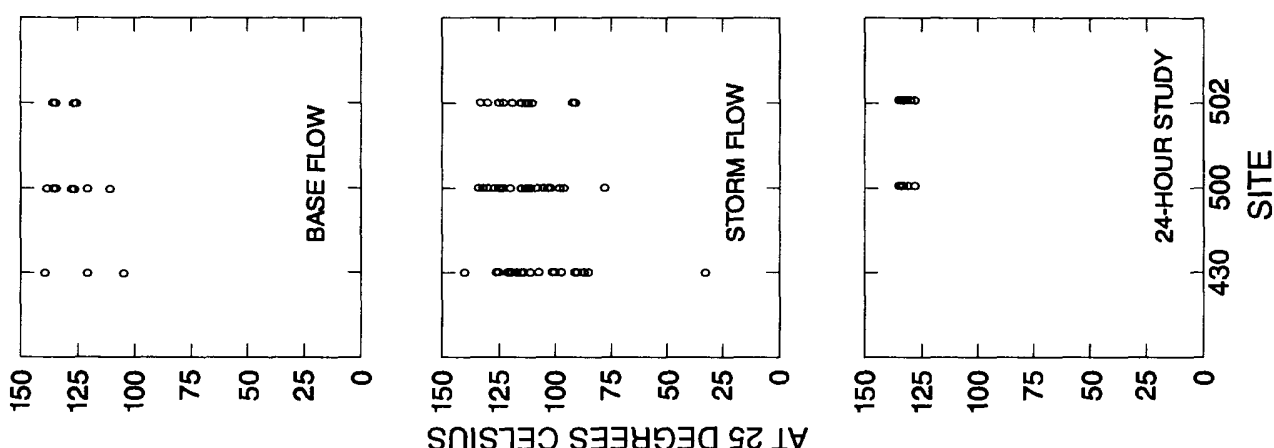

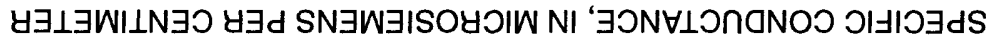
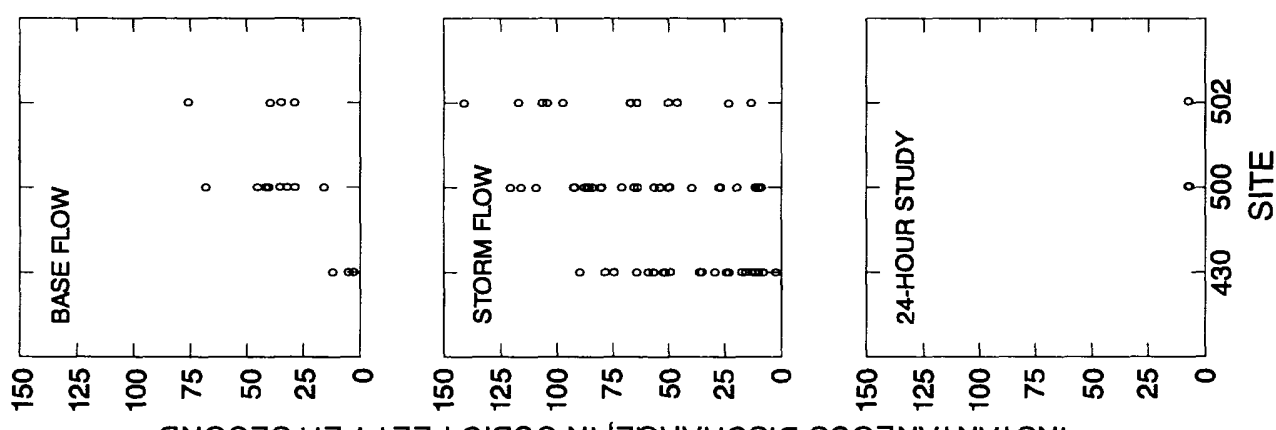

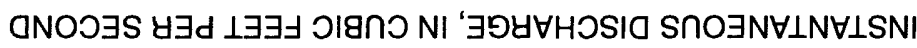



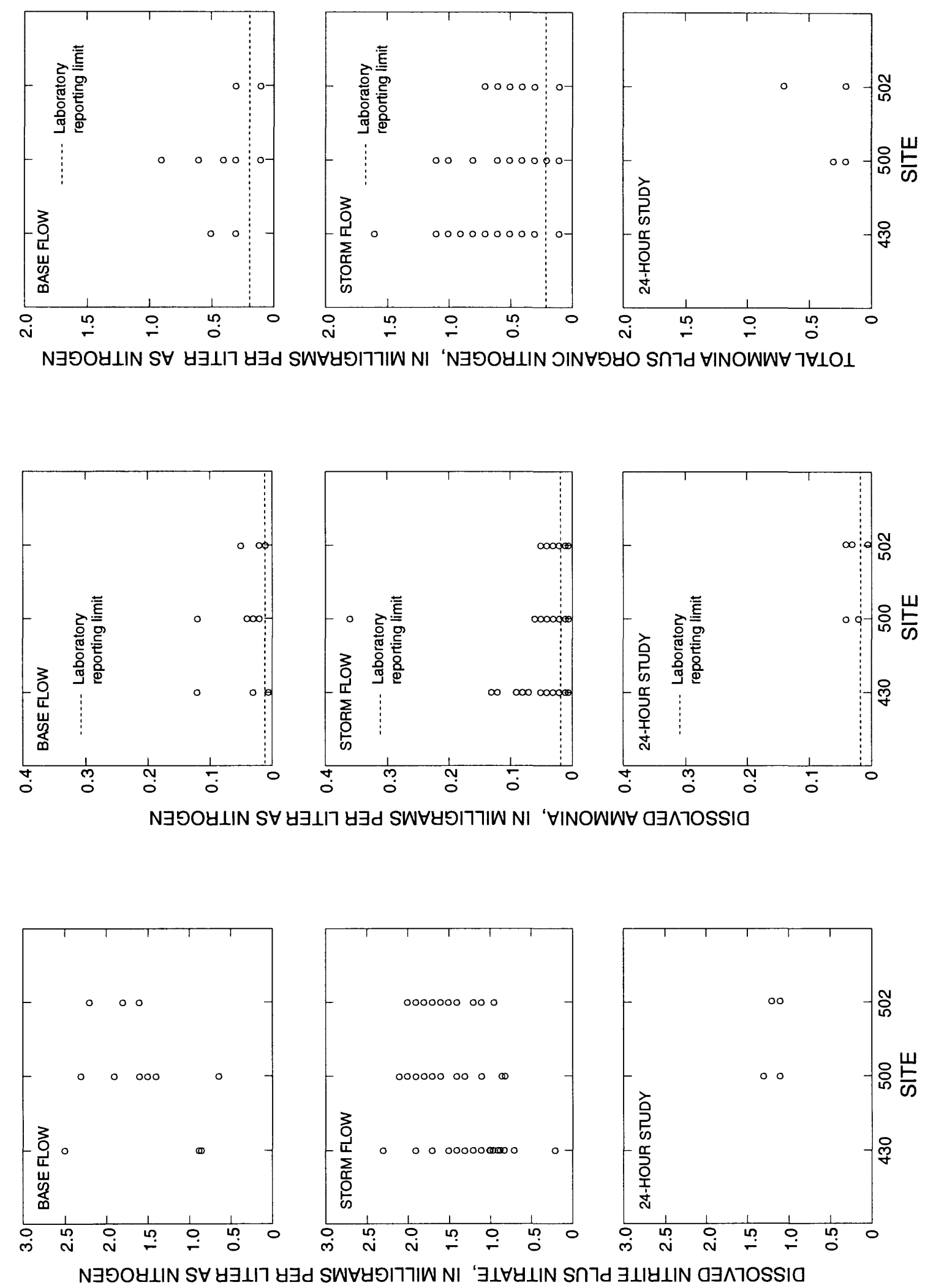

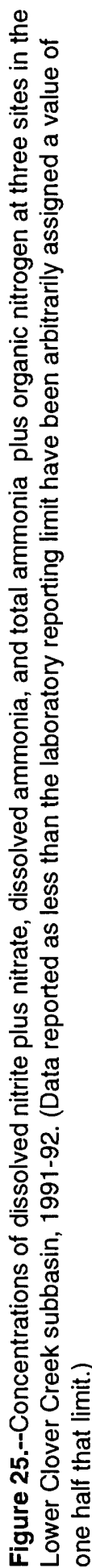

N $\exists$ פOULIN S $\forall$ y $\exists \perp 17$ y 

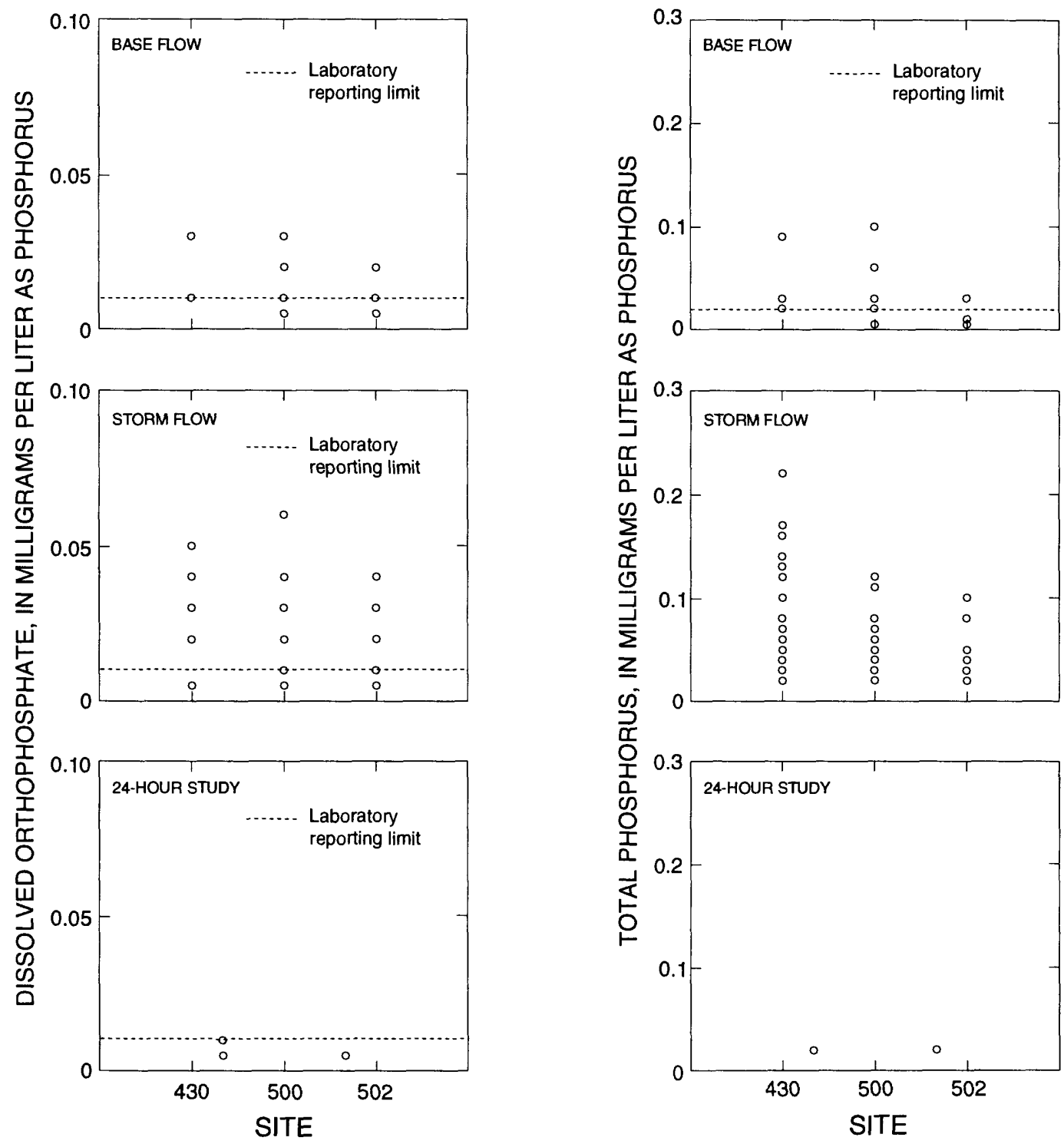

Figure 26.--Concentrations of dissolved orthophosphate and total phosphorus at three sites in the Lower Clover Creek subbasin, 1991-92. (Data reported as less than the laboratory reporting limit have been arbitrarily assigned a value of one half that limit.) 

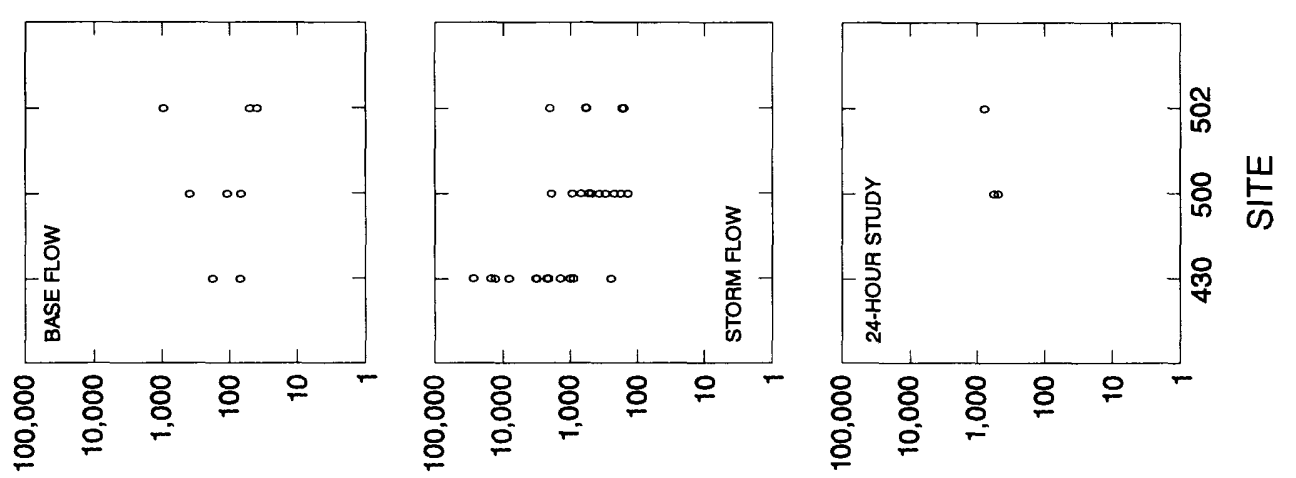

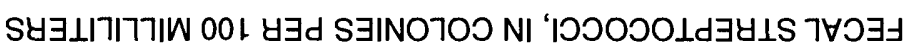
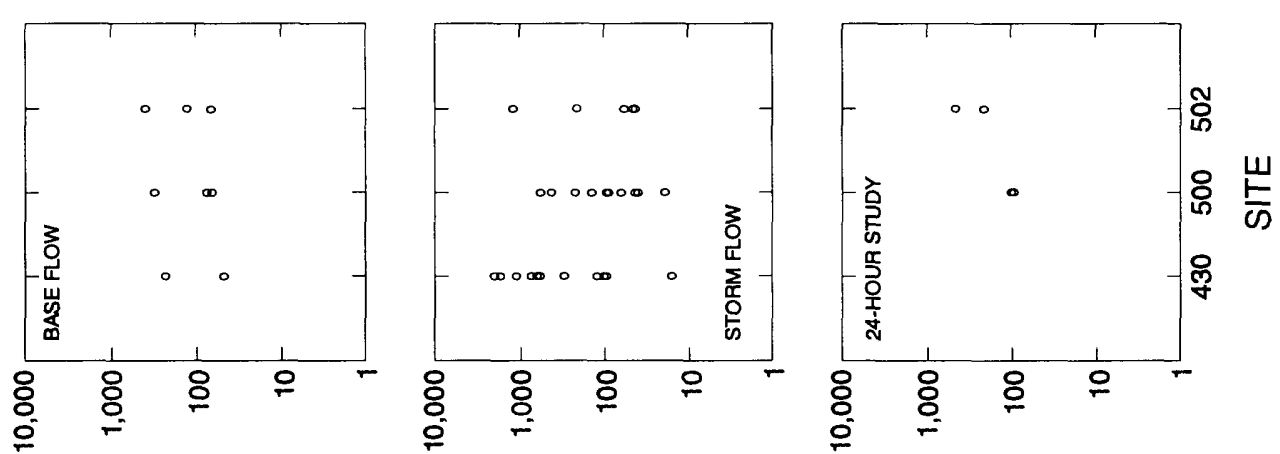

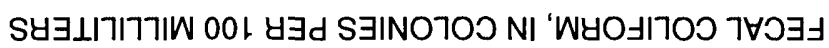
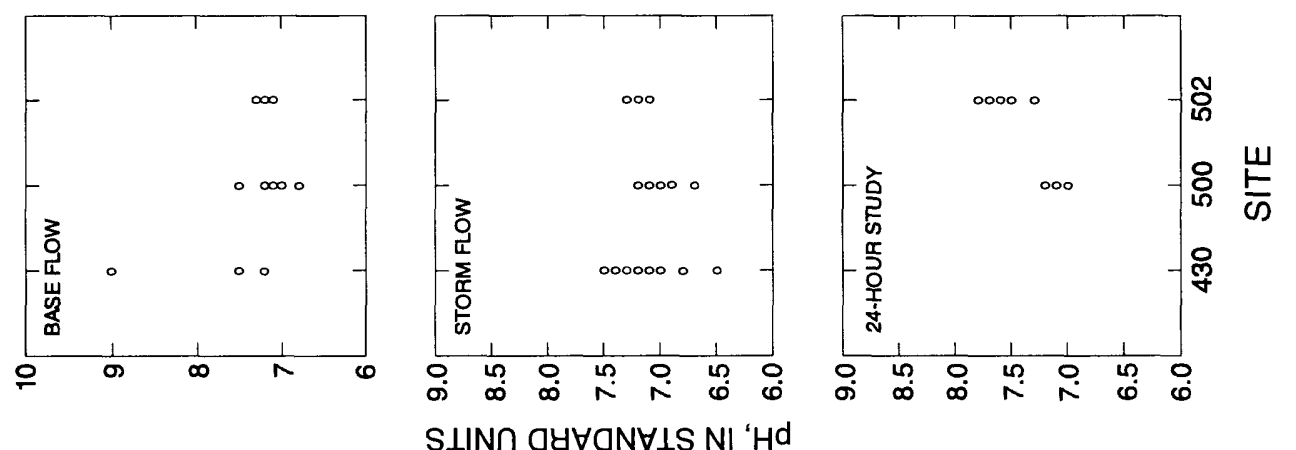

ণั่
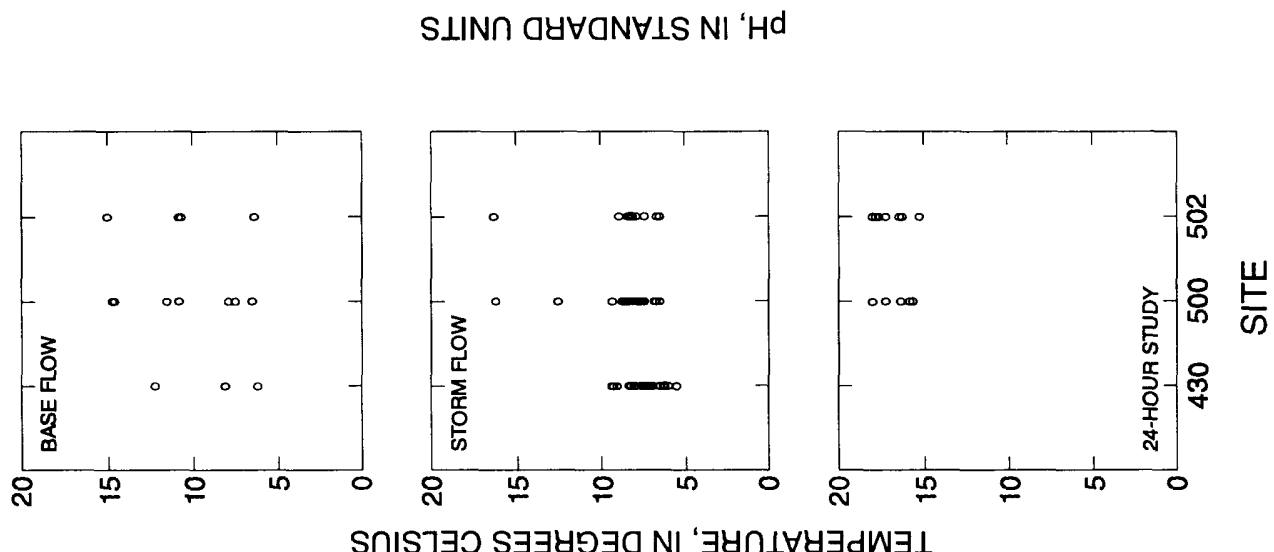

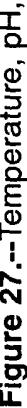
SกISา $\exists \supset$ S $\exists \exists y 9 \exists \square$ NI ' $\exists y \cap \perp \forall y \exists d W \exists \perp$ 


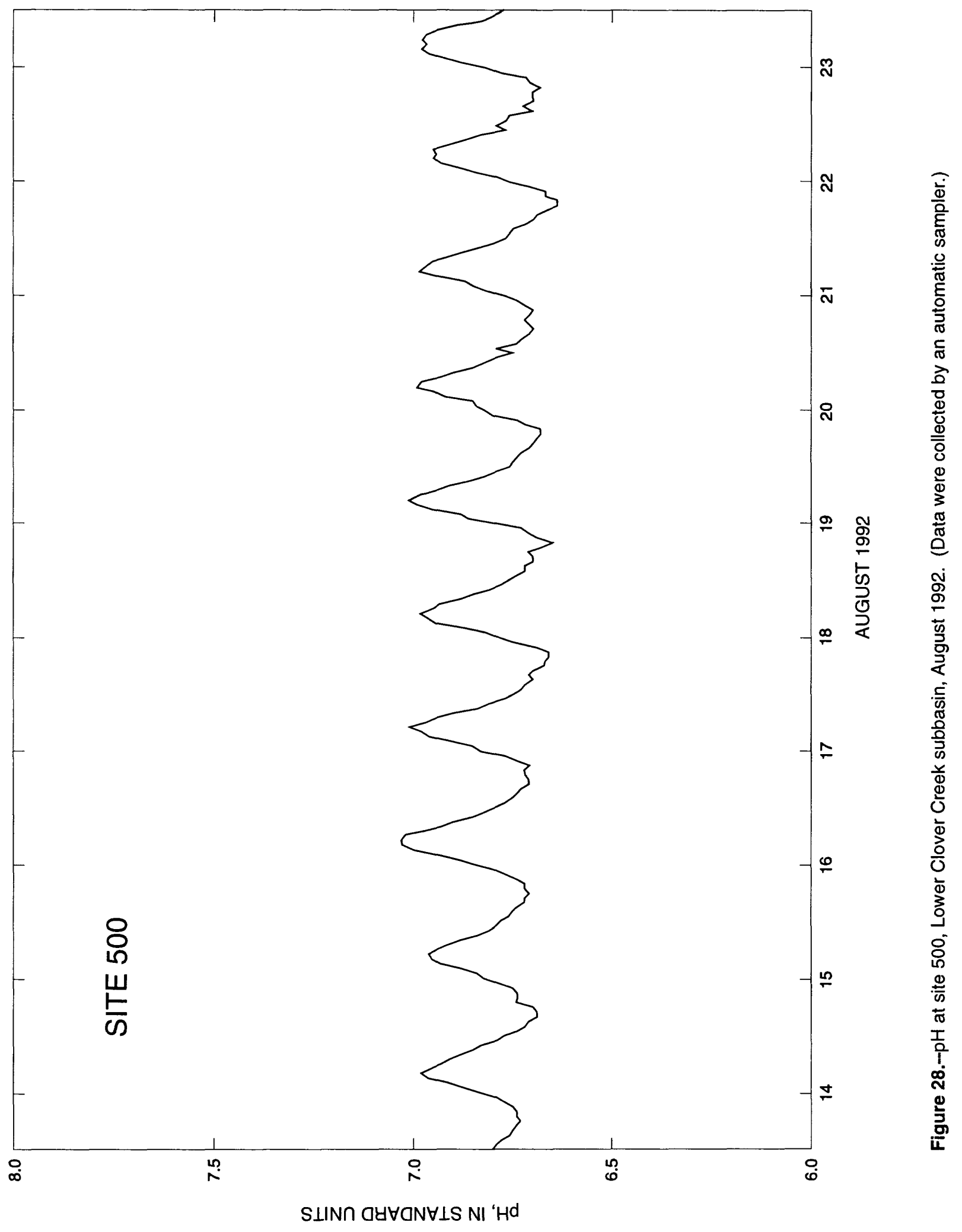



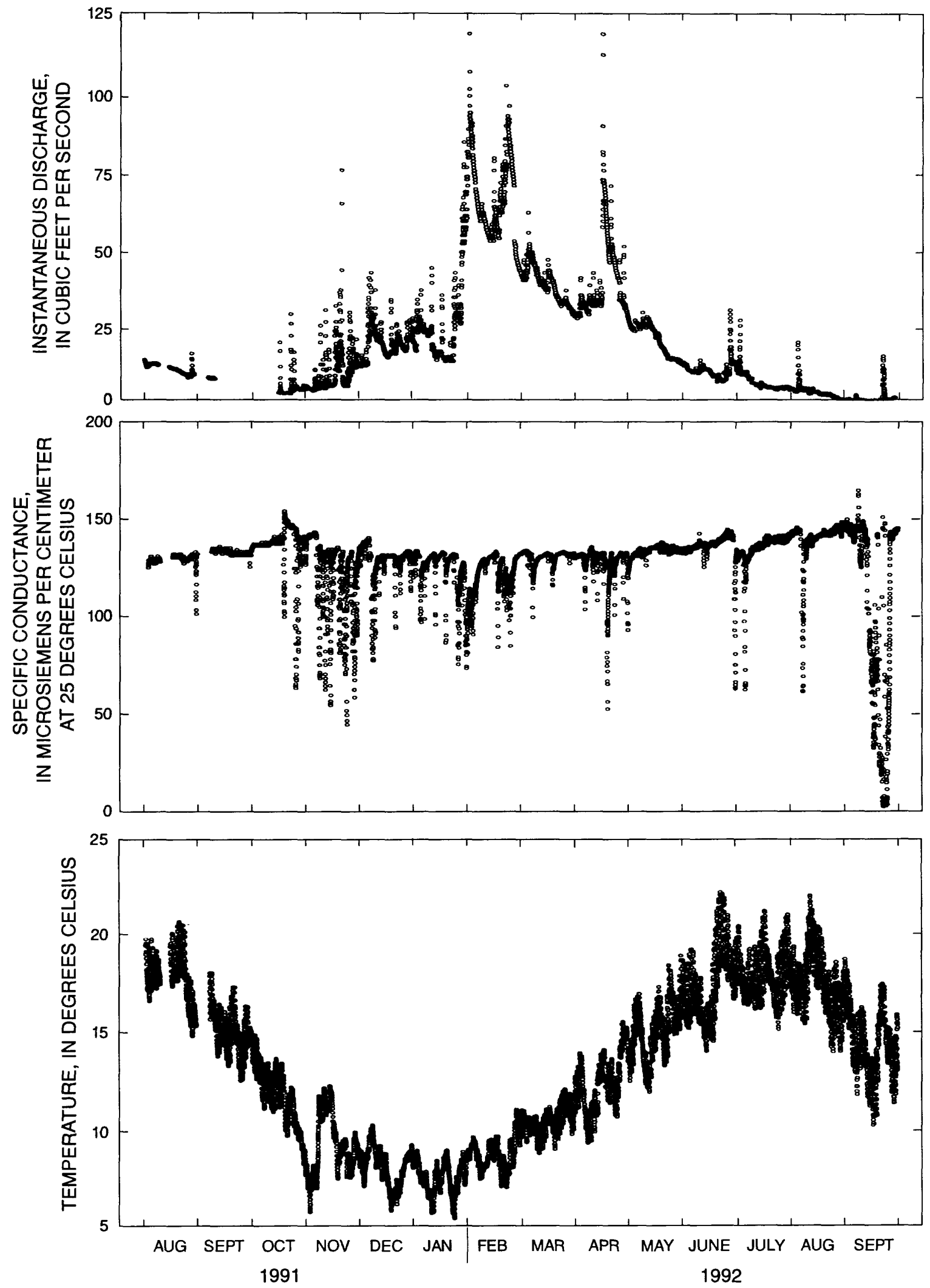

Figure 29.--Instantaneous discharge, specific conductance, and temperature at site 500, Lower Clover Creek subbasin, 1991-92. (Specific conductance and temperature data were collected by an automatic sampler.) 
Copper, lead, and zinc concentrations measured in the water column were moderate at site 430 and somewhat lower downstream at sites 500 and 602 (table 4).

Although elevated concentrations of these metals would be expected in an urbanized area such as the Lower Clover Creek subbasin, their affinity for solid-phase materials, coupled with low concentrations of suspended sediment in this subbasin, leads to low concentrations in the water column. In contrast, the effects of urbanization are manifested in the bed-sediment data (table 5). Copper and zinc concentrations in bed-sediment material were moderately high, and lead concentrations were considerably higher than elsewhere in the basin.

Dissolved-oxygen and biochemical-oxygen demand was measured at sites 500 and 602 (fig. 30). In addition, all sites in the Lower Clover Creek subbasin-430, 500, and 602-were sampled for selected organic compounds on three separate occasions. These organic compounds were not present in concentrations at or above the laboratory reporting limit (Appendix A, table A6).
Water-quality data were collected during the 1960's and 1970's at historical site 600, just upstream of current site 602 (fig. 6). Comparison of data from the current study with available historical data (fig. 31) shows an increase in chloride concentrations and a moderate increase in specific conductance in the subbasin over the past two to three decades. Both of these can be attributed to increased urbanization of the area. In contrast, the data show that phosphorus concentrations have not changed substantially over the past few decades. This lack of change, however, is also consistent with increased land development. Because the use of phosphates in detergents has declined considerably over the past decades, phosphorus concentrations in typical waste-disposal system effluent have declined. This decline is demonstrated by the comparison of historical and current phosphorus concentrations in the Upper Clover Creek subbasin (fig. 14).

However, increases in other sources of phosphorus associated with land development, such as fertilizers and domestic pets, have apparently compensated for this decline and resulted in little net change in phosphorus concentrations in the Lower Clover Creek subbasin.
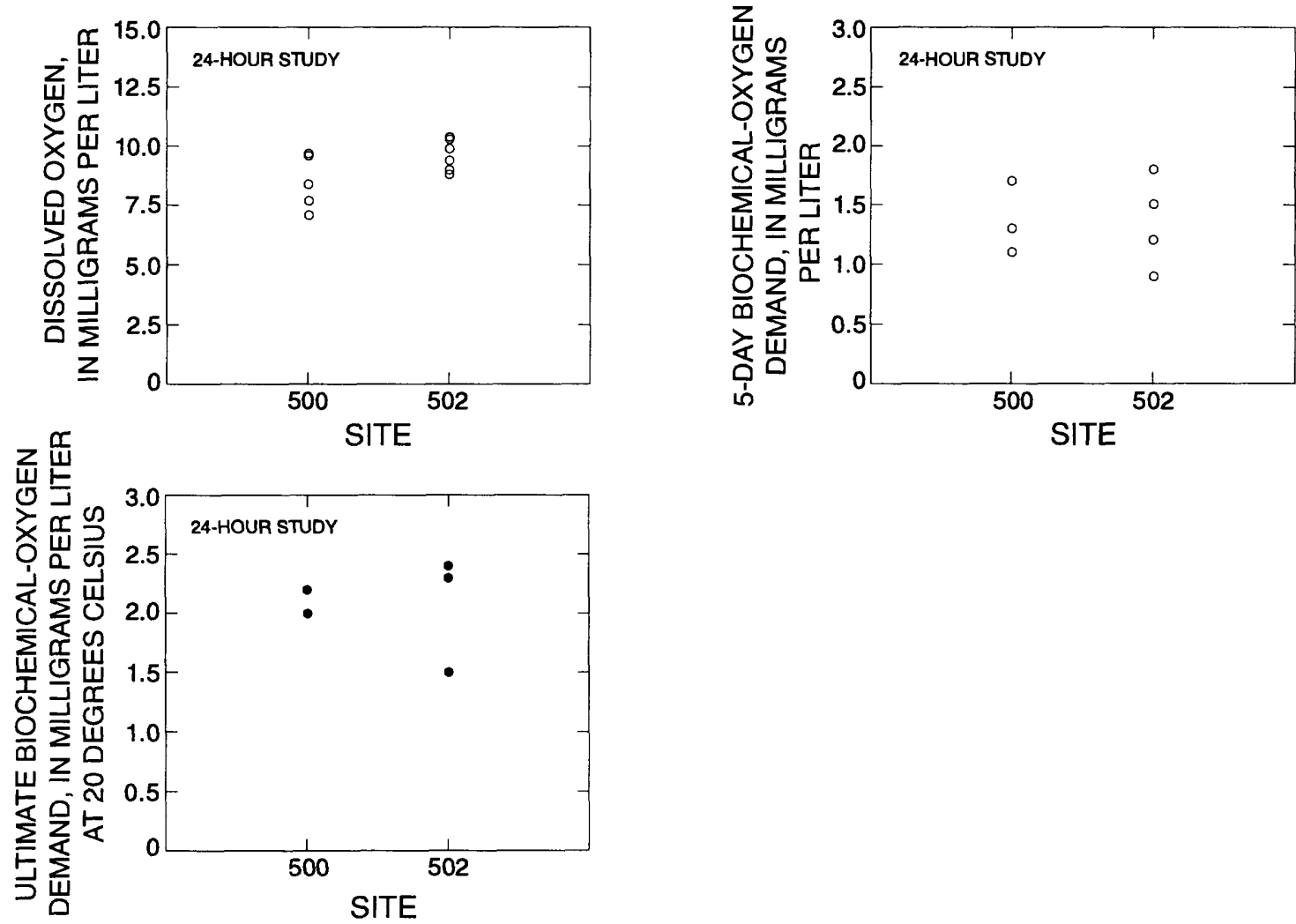

Figure 30.--Dissolved oxygen, 5-day biochemical-oxygen demand, and ultimate biochemical-oxygen demand at two sites in the Lower Clover Creek subbasin, 1991-92. 

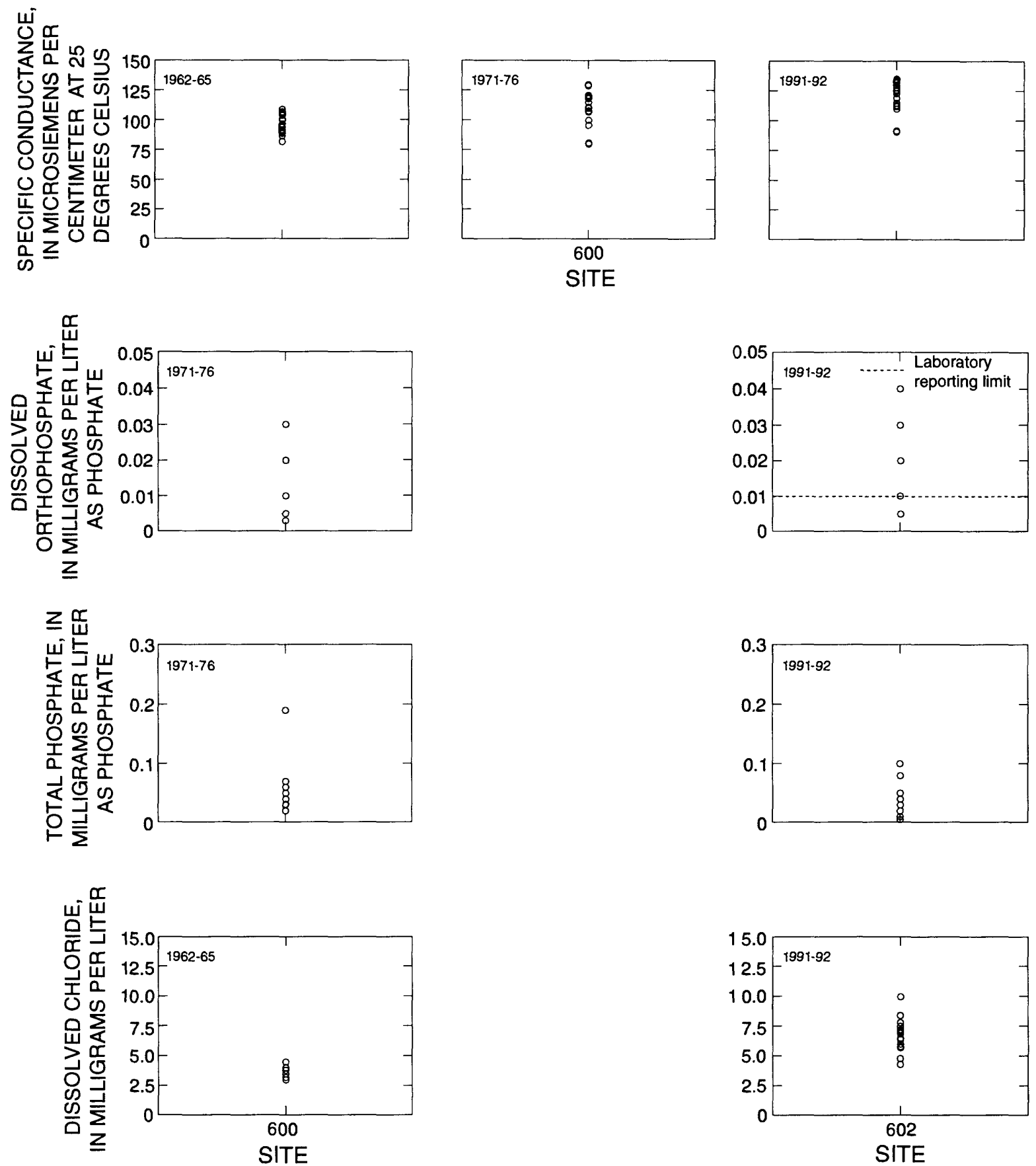

Figure 31.-Specific conductance and concentrations of dissolved orthophosphate, total phosphate, and dissolved chloride at site 600, 1962-65 and 1971-76, and at site 602, 1991-92, Lower Clover Creek subbasin. 


\section{Catchment Areas--Sites 340, 365, and 380}

In contrast to the sites discussed so far, which were all located along the principal streams of the basin, sampling sites 340,365 , and 380 were located at the outflows of the three catchment areas, upstream of their confluences with primary streams. Data from these sites thus show the quality of runoff from these small areas before it is integrated with more regional flow in the larger streams. In addition, because of the limited sizes of the areas, discharges are small (fig. 32), and flow paths and travel times of runoff are relatively short. These factors provided an opportunity to examine the quality of direct storm runoff before substantial chemical and biological transformations had occurred. It should be noted, however, that as a result of the limited sizes of the catchment areas, flow at these sites generally does not persist between storms. As a result, only limited base-flow data are available, and meaningful comparisons between base- and storm-flow data are not possible.

The water-quality characteristics observed at site 340 show the effects of high-density residential land-use practices. Concentrations of dissolved nitrite plus nitrate and ammonia (fig. 33) and dissolved orthophosphate (fig. 34) were the highest observed in the basin, indicating that residential sources such as domestic waste water, landscape activities, and domestic pets contribute substantial amounts of these constituents to streams. Concentrations of nitrite, an intermediate biodegradation product formed during the nitrification process, were also the highest observed throughout the study area (Appendix A, table A2). Lead concentrations at this site were also the highest observed in the basin (table 4), probably because a large part of the catchment area is covered by roadways and driveways. The data also show that suburban land use produces high levels of specific conductance, suspended sediment, and chloride (fig. 32), total ammonia plus organic nitrogen (fig. 33), phosphorus (fig. 34), fecal bacteria (fig. 35), and zinc (table 4). This neighborhood continues to be served by on-site waste-disposal systems, and although discharge at site 340 is believed to consist primarily of surface runoff, effluent from waste-disposal systems may sometimes enter the stream because of inadequate infiltration through the low-permeability glacial till that underlies this area. The $\mathrm{pH}$ values measured at site 340 (fig. 35) were the lowest in the basin. As in the North Fork subbasin, the short residence time of water within this 10-acre catchment area results in low-pH outflow.
The rural catchment area (site 365), located in the North Fork subbasin (fig. 6), is underlain by the lowpermeability glacial till characteristic of the subbasin (fig. 3). As discussed in the section on land-use practices, this 90 -acre area is covered by forest and grass and is currently used as pasture for cattle. Decaying plant debris and animal wastes thus serve as steady, ongoing sources of nutrients and fecal bacteria within the catchment area. However, despite the low permeability of the subsurface materials, uptake by plants and the natural filtering capability of the undisturbed ground cover in this rural area damp the loads of these constituents entering the stream. This filtering phenomenon is manifested by the low to moderate, generally stable concentrations of specific conductance and suspended sediment (fig. 32), ammonia and total ammonia plus organic nitrogen (fig. 33), phosphorus (fig. 34), and fecal coliform and streptococci (fig. 35). Although the values of $\mathrm{pH}$ measured at this site were somewhat higher than those measured at the other catchment sites (sites 340 and 380, fig. 35), they were, nonetheless, among the lowest in the entire Clover Creek Basin, and specific conductance values at this site (fig. 32) were the lowest measured throughout the study area. Once again, the short residence time of water within the catchment area contributes to the low $\mathrm{pH}$. The low specificconductance values observed at site 365 can be attributed to both the short residence time of water in the catchment area and the lack of developed areas and paved surfaces. The low dissolved nitrite plus nitrate concentrations may also be due, in part, to the short residence time. As explained in the discussion of site 330 , nitrifying bacteria oxidize organic nitrogen first to ammonia, then to nitrite, and finally to nitrate. At site 365 , however, despite the apparently adequate supply of organic material present in the catchment area, it is evident that either sufficient time or appropriate conditions are not available for the microbial population to transform large amounts of organic nitrogen to nitrate. The low chloride (fig. 32), dissolved nitrite plus nitrate (fig. 33), and metal (table 4) concentrations also reflect the lack of urbanization and absence of subsurface sources such as waste-disposal systems. 

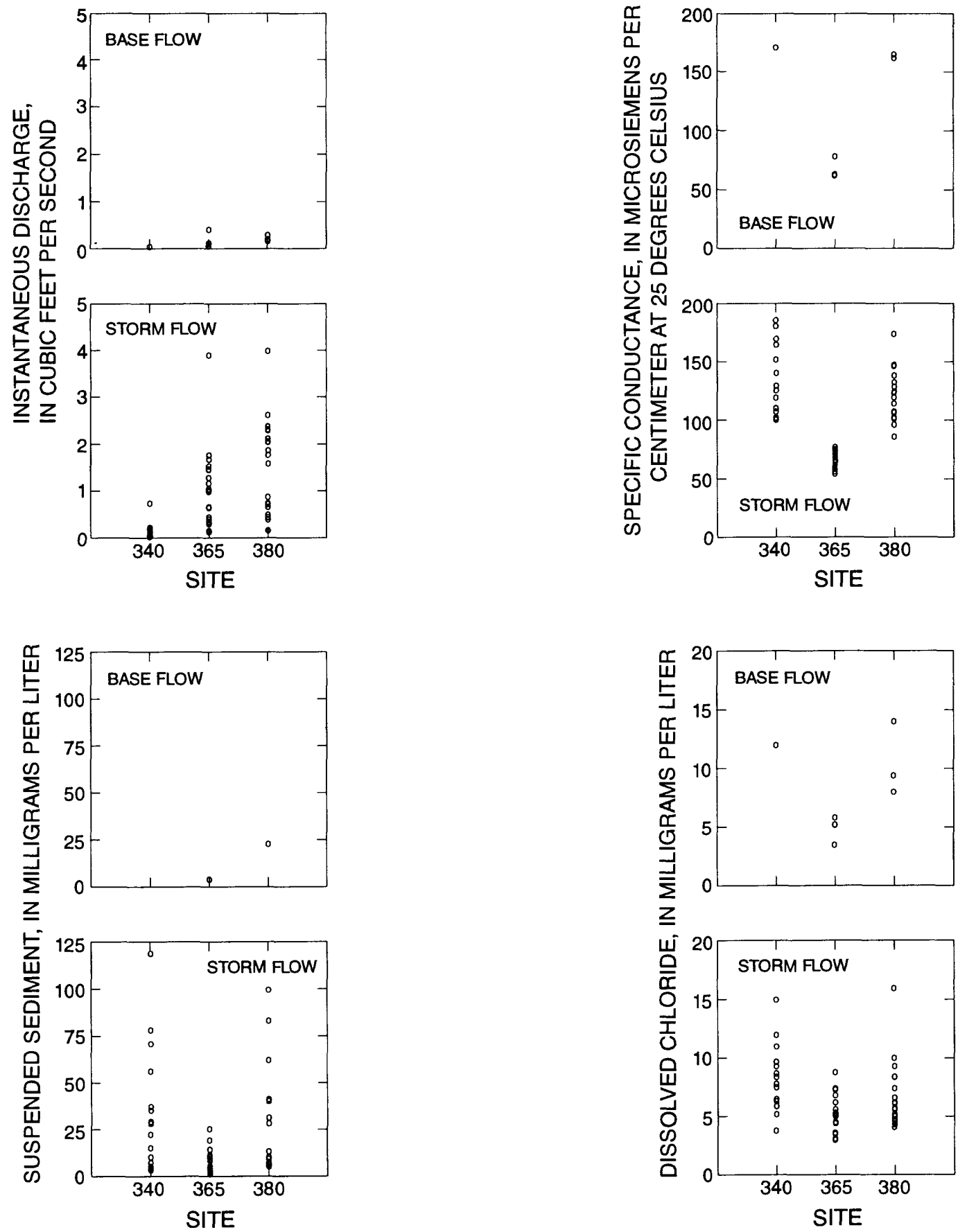

Figure 32.--Instantaneous discharge, specific conductance, and concentrations of suspended sediment and dissolved chloride at three catchment area sites in the Clover Creek Basin, 1991-92. 

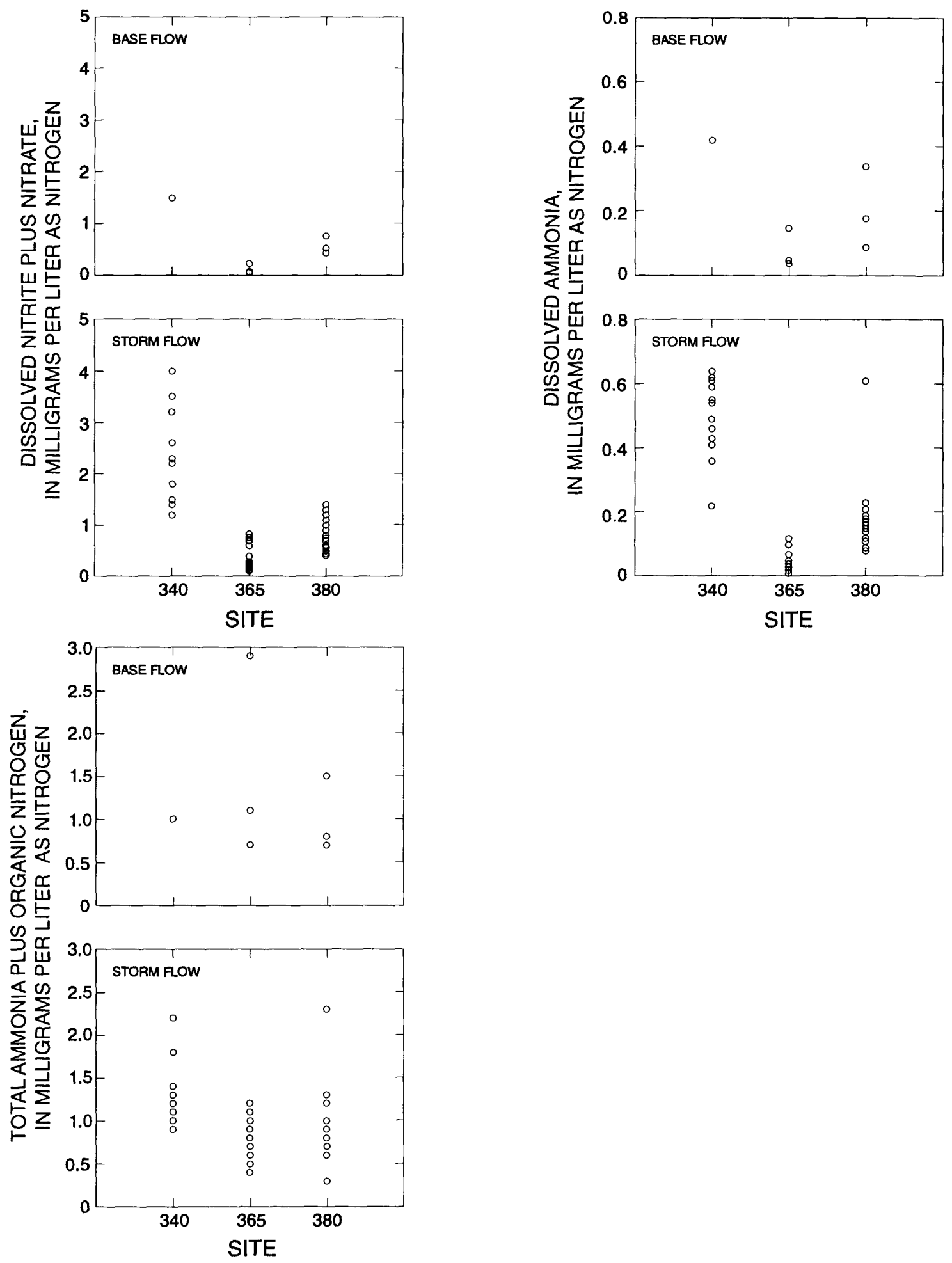

Figure 33.--Concentrations of dissolved nitrite plus nitrate, dissolved ammonia, and total ammonia plus organic nitrogen at three sites in the Upper Clover Creek subbasin, 1991-92. (Data reported as less than the laboratory reporting limit have been arbitrarily assigned a value of one half that limit.) 
As with the other two catchment areas, the waterquality characteristics observed at site 380 reflect the short residence time of water within the area. However, in contrast to sites 340 and 365 , water quality at site 380 represents an integration of the effects of land-use practices ranging from low-density residential to commercial development. The water-quality characteristics observed were similar to those observed at site 340 except for dissolved nitrite plus nitrate (fig. 33), dissolved orthophosphate (fig. 34), and lead and zinc concentrations (table 4), which were all lower than those at site 340 . Because the site

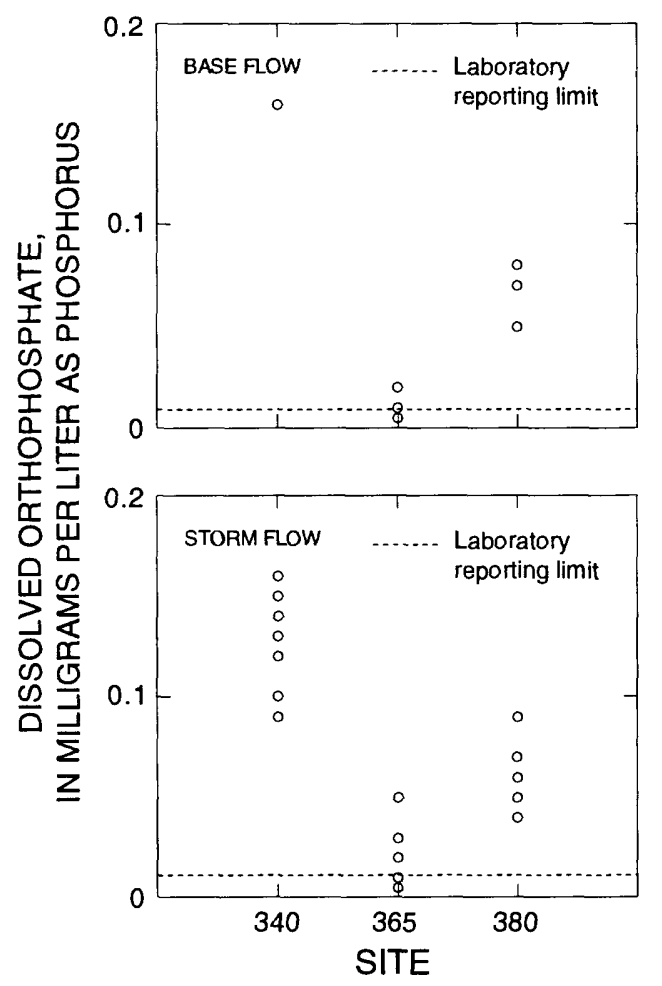

380-catchment area has a lower percentage of high-density housing than the site-340 catchment area (table 1), it is likely that landscaping activities in this catchment area (site 380) are less intensive. Reduced use of lawn fertilizers, for example, may be responsible for the nitrogen and phosphorus concentrations observed here, which were lower than at site 340 . The site- 380 catchment area is also characterized by a lower percentage of effective impervious area (Mastin, 1996), including paved roadways and driveways, which likely accounts for the lower lead and zinc concentrations measured at this site.

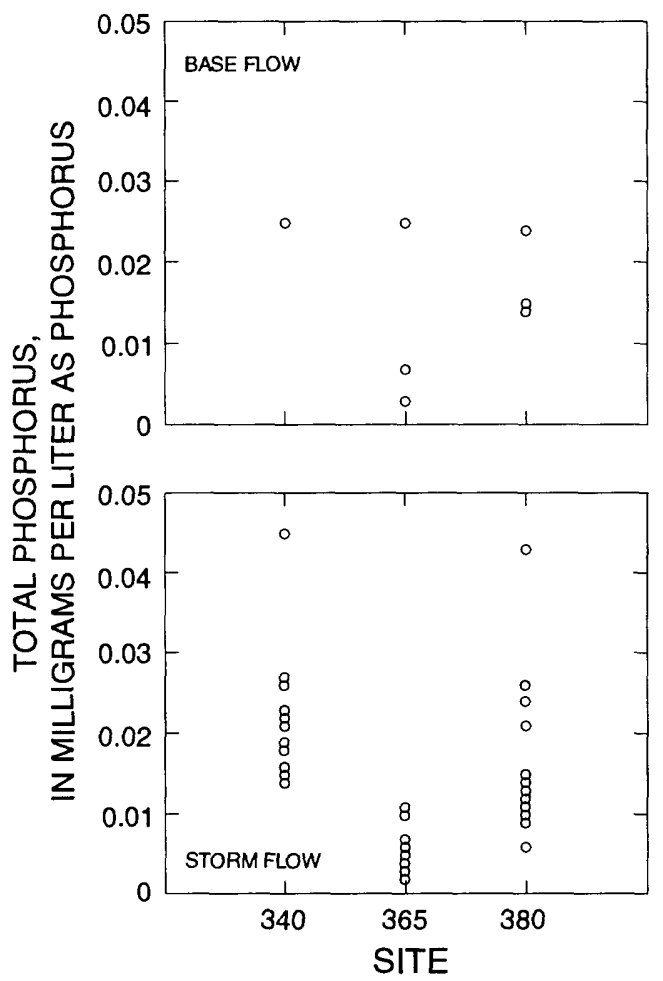

Figure 34.--Concentrations of dissolved orthophosphate and total phosphorus at three catchment area sites in the Clover Creek Basin, 1991-92. (Data reported as less than the laboratory reporting limit have been arbitrarily assigned a value of one half the limit.) 

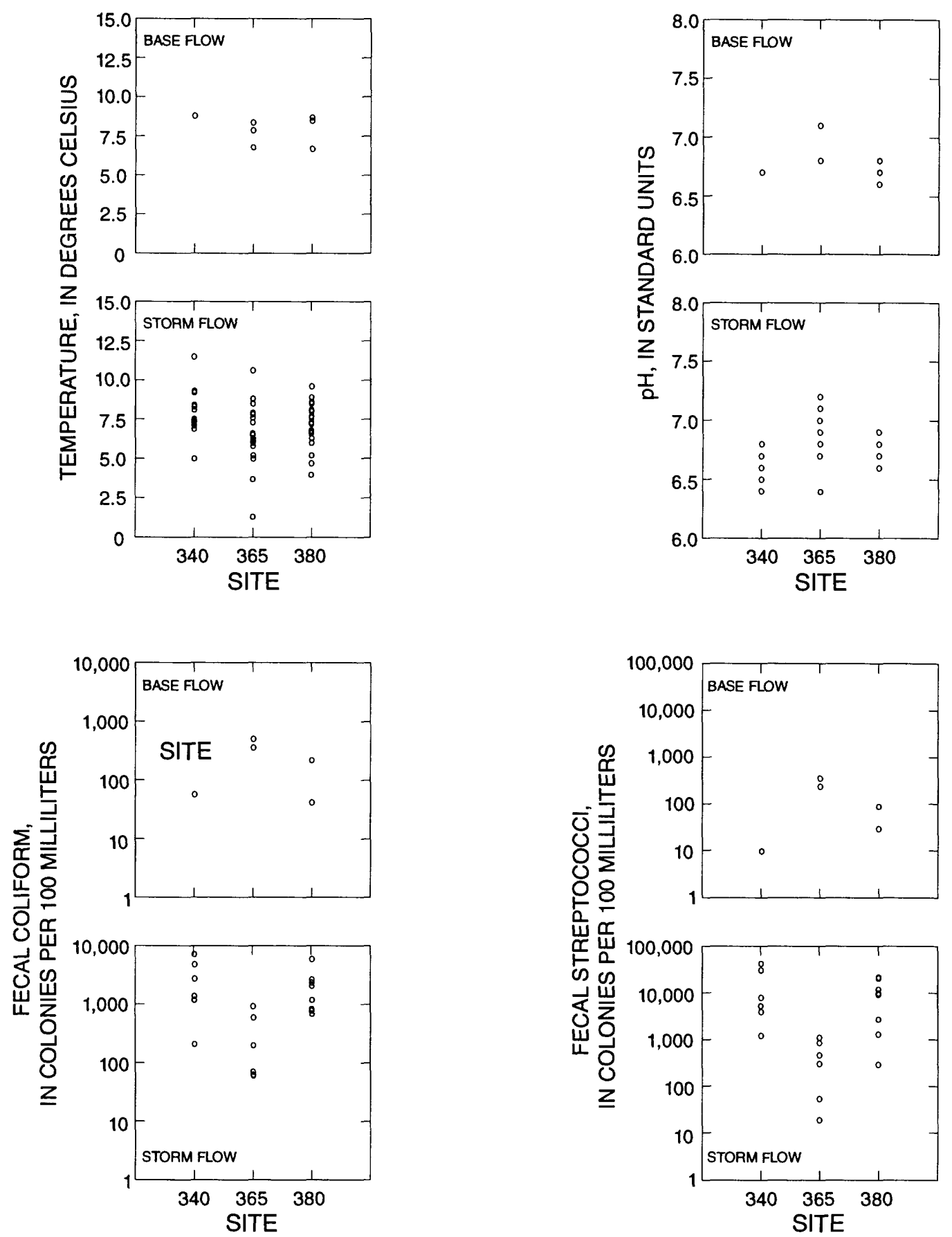

Figure 35.--Temperature, $\mathrm{pH}$, fecal coliform, and fecal streptococci at three catchment area sites in the Clover Creek Basin, 1991-92. 


\section{Comparison of Water Quality}

\section{Among Subbasins}

It is clear from the preceding discussion that differences in surficial geology, land use, and waste-disposal practices are reflected in the water-quality characteristics of various parts of the Clover Creek Basin and that the hydraulic effects of lakes can alter these characteristics. In this section, selected water-quality data from the four subbasins and three catchment areas will be directly compared and contrasted to further illustrate these points.

The effects of impervious surfaces associated with urbanization and low-permeability soils are manifested by the large differences in water quality between base- and storm-flow conditions at sites 370,395 , and 400 in the North Fork subbasin (figs. 36-37). These same effects are seen downstream at sites 430,500, and 602 in the Lower Clover Creek subbasin, partly because of the influence of the North Fork subbasin and partially because of the characteristics of the Lower Clover Creek subbasin itself. Similar effects would be expected in the suburban catchment area (site 340), but limited base-flow data from the catchment areas do not allow meaningful comparisons between base- and storm-flow conditions.

Comparison of data from the rural catchment (site 365 ) with those from the rest of the basin shows that all developed areas contribute to elevated dissolved nitrite plus nitrate concentrations in streams. The greatest concentrations, however, were observed at the suburban catchment (site 340) and in the Upper Clover Creek subbasin (sites 330, 355, and 360), and as previous discussion indicates, it is likely that different sources and transport mechanisms are responsible for the high concentrations in each of these two areas. The low phosphorus and ammonia concentrations and the very stable behavior of dissolved nitrite plus nitrate in the Upper Clover Creek subbasin indicate that ground water is the primary source of dissolved nitrite plus nitrate within the subbasin. At site 340 , both dissolved nitrite plus nitrate and phosphorus concentrations were high, indicating surface or shallow subsurface sources such as fertilizers, domestic pets, and effluent from on-site waste-disposal systems that do not operate efficiently because of low-permeability soils.

The data also show that concentrations of ammonia, phosphorus, suspended sediment, and fecal coliform were considerably higher in the North Fork subbasin and developed catchment areas (sites 340 and 380) than in the rest of the basin. Once again, these elevated concentrations can be attributed to the impermeable surfaces and highdensity populations characteristic of urbanized areas. Because low-permeability soils in these areas also inhibit deep infiltration and promote direct surface or shallow subsurface runoff, attenuation resulting from subsurface transport is minimal.

Finally, data from the Spanaway subbasin (sites 452 , 460 , and 480) show how the presence of lakes within a subbasin can alter water quality. In comparison to the other subbasins, specific conductance, nutrient concentrations, bacteria counts, and metal concentrations in the Spanaway subbasin were generally low to moderate. However, these data do not necessarily indicate that land use within the subbasin does not contribute substantial amounts of these constituents. Because many constituents tend to accumulate within lakes due to biological uptake and the settling of suspended materials, water quality downstream from lakes may not reflect the influence of upstream sources of constituents. 

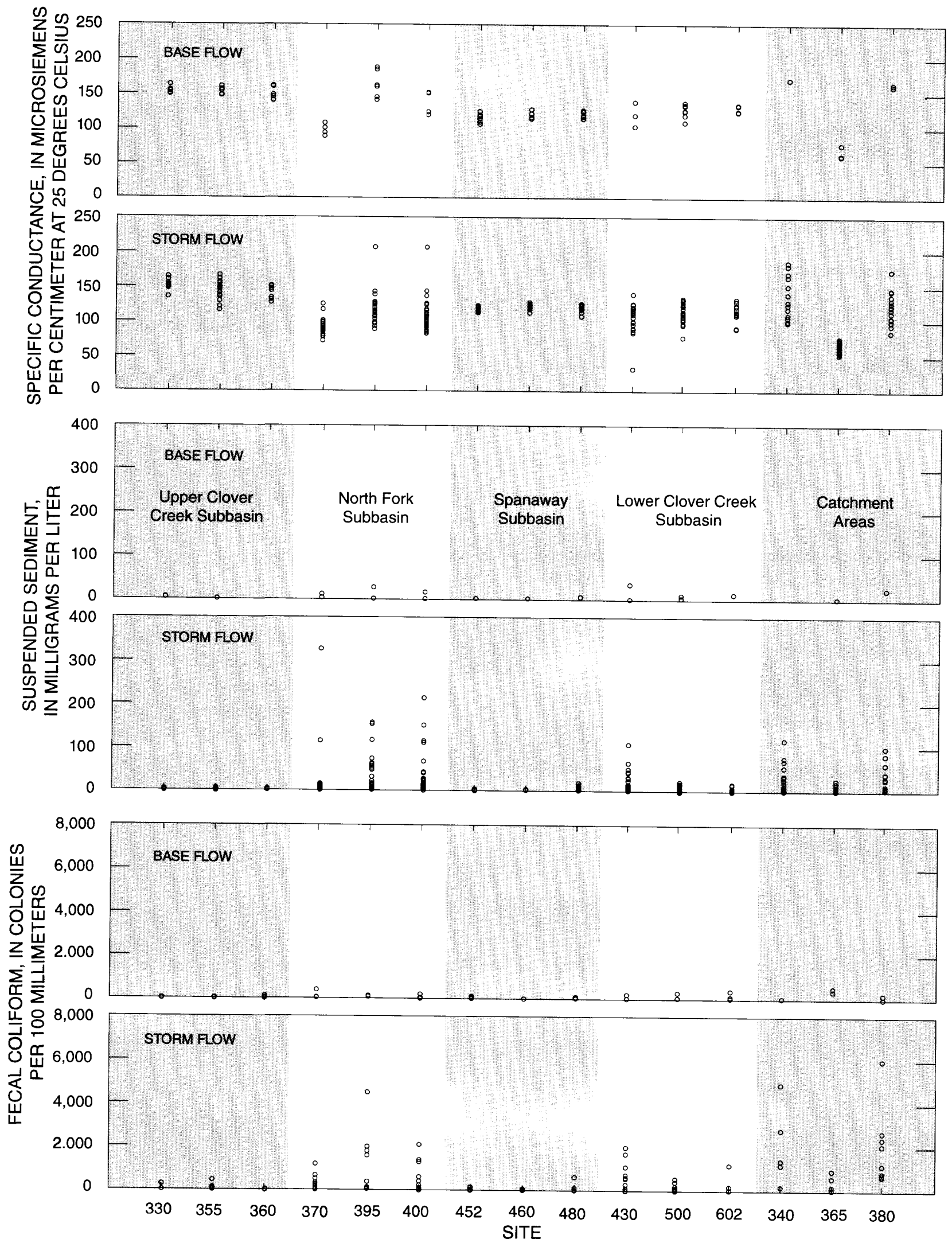

Figure 36.--Specific conductance and concentrations of suspended sediment and fecal coliform at all primary data-collection sites in the Clover Creek Basin, 1991-92. 


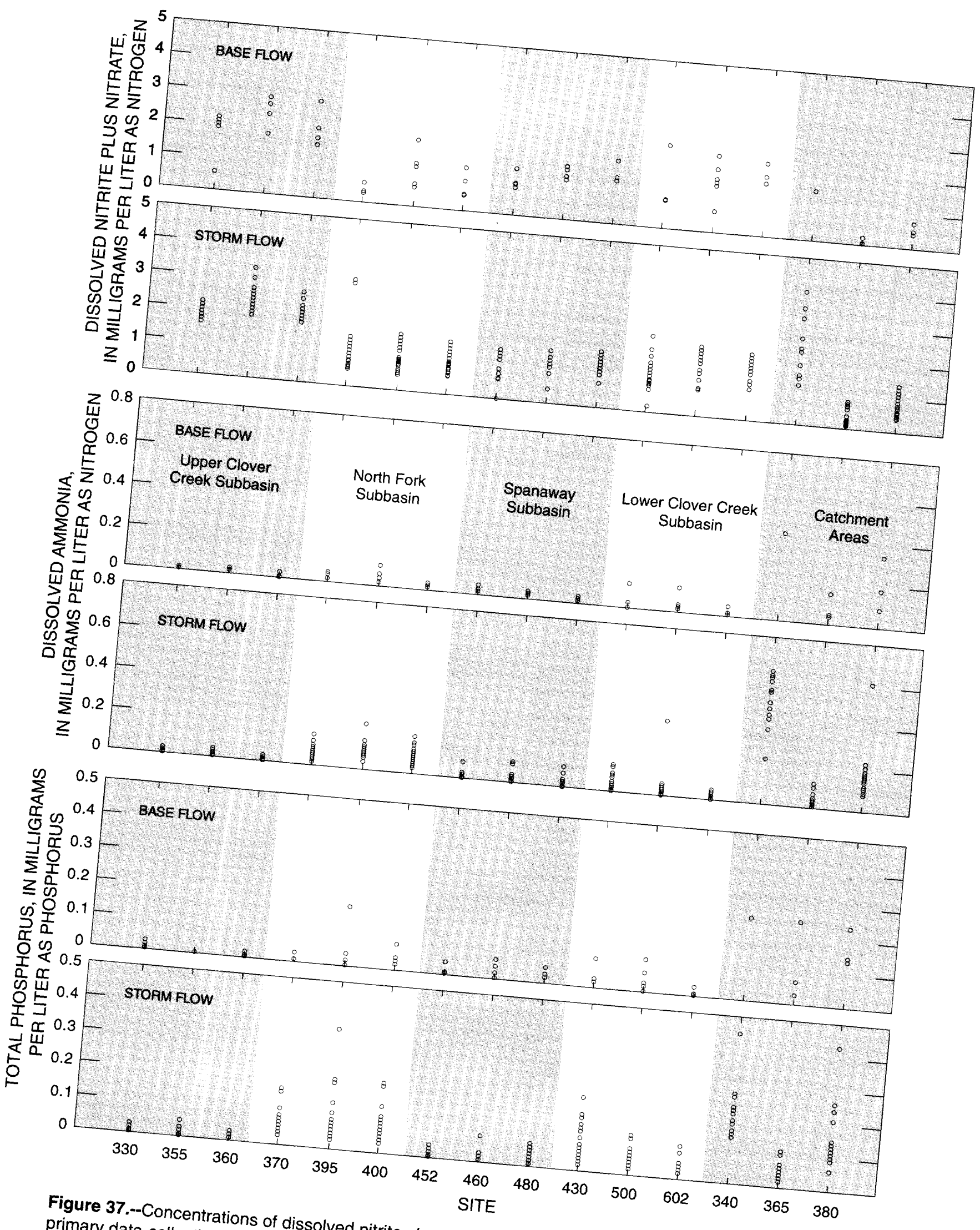

$\begin{array}{llll}\text { primary data-collection } & \text { SITE } & 365 & 380\end{array}$ 


\section{Nutrient Loading to Steilacoom Lake}

All surface-water discharge from the Clover Creek Basin flows into Steilacoom Lake (fig. 2). Nuisance algal blooms have occurred in the lake in the past and continue to be of concern, particularly because the entire shoreline of this 320-acre lake is occupied by residential development. Because the availability of nutrients such as nitrogen and phosphorus is critical to algal populations, the quantities of these nutrients that enter Steilacoom Lake from various sources are of interest. Clover Creek is one such source, and the nutrient loads entering Steilacoom Lake from Clover Creek were therefore estimated from the stream-discharge and nutrient-concentration data collected at site 500 over the course of this study.

Site 500 was chosen because of its proximity to the inlet to Steilacoom Lake, the relatively large number of nutrient samples collected there, and the availability of hourly discharge data for the site.

Constituent loading rates can be defined as the product of constituent concentration and stream discharge:

$$
L_{i}=C_{i} \times Q,
$$

where $L_{i}$ is the loading rate of constituent $i$ (mass per time), $C_{i}$ is the concentration of constituent $i$ (mass per volume), and $Q$ is the stream discharge (volume per time). For nitrogen loading-rate calculations, total nitrogen was estimated as the sum of dissolved nitrite plus nitrate and total ammonia plus organic nitrogen. Total phosphorus concentrations were used for calculating phosphorus loading rates. For those concentrations reported as less than the laboratory reporting limit, an arbitrary value, equal to one half the laboratory reporting limit, was substituted for loading-rate calculations. Initial estimates of monthly loading rates (table 6) were calculated from the average value of all instantaneous constituent concentration data collected during that month and the average monthly stream discharge as measured by the automated monitor located at site 500 .

A regression model (Cohn and others, 1992) was also used to estimate monthly nitrogen loading rates to Steilacoom Lake. In order to calculate nitrogen loading rates, measured total nitrogen concentrations were regressed against stream discharge to yield the regression equation

$$
\ln \left(C_{N}\right)=0.092+0.150 \ln (Q),
$$

where $C_{N}$ is total nitrogen concentration, in $\mathrm{mg} / \mathrm{L} ; Q$ is the stream discharge, in cubic feet per second; and $l n$ indicates the natural (base $e$ ) logarithm. Equation 3 was developed on the basis of all available concentration data and average daily discharge values. Additional predictor variables to account for seasonal variations or long-term trends in concentration were not included in the regression because of the uneven seasonal distribution of the data and the relatively short period (less than 2 years) of data collection. The regression line calculated from equation 3 , along with actual data, is shown on figure 38 .

Using regression equation 3 and the relation given by equation 2, nitrogen loading rates can be expressed as a function of stream discharge only:

$$
\ln \left(L_{N}\right)=0.987+1.150 \ln (Q),
$$

where $L_{N}$ is the total nitrogen loading rate, in kilograms per day. Monthly nitrogen loading rates estimated with the regression model are shown in table 6. Although the correlation between nitrogen concentration and discharge is statistically significant $(p=0.0002)$, the relation, as illustrated by figure 38 , is weak $\left(R^{2}=0.31\right)$. Because this relation is weak, loads estimated using equation 2 , which assumes no relation exists, are similar to those estimated using regression equation 4 . Furthermore, because the range of total nitrogen concentrations is small $(1.69 \mathrm{mg} / \mathrm{L})$, the use of monthly average concentrations in equation 2 yields results similar to those of the regression equation 4 .

Estimates of phosphorus loading rates (table 6) were calculated with equation 2 . Calculations were based on monthly averages of total phosphorus concentration and stream discharge. Because no statistically significant correlation exists between stream discharge and phosphorus concentrations $p=0.97$, the regression model was not used to estimate phosphorus loading rates. 
Data presented and discussed in the earlier section on water quality in the Lower Clover Creek subbasin showed that nutrient concentrations at site 500 did not vary significantly between base- and storm-flow conditions. Results from the regression model (Cohn and others, 1992) also indicated that the dependence of concentration on discharge is weak for nitrogen and insignificant for phosphorus. As a result, estimated nutrient loads vary with stream discharge in a nearly linear fashion, and the magnitude of the discharge rather than changes in nutrient concentrations is the most important factor currently governing nutrient loading from Clover Creek to Steilacoom Lake. Seasonal variations in nutrient concentrations may also substantially affect nutrient loads, but additional data would be required to quantify these effects.

Table 6.--Estimated average monthly nitrogen and phosphorus loads at site 500 in the Clover Creek Basin, 1991-92 [ft $\mathrm{ft}^{3} / \mathrm{s}$, cubic foot per second; $\mathrm{mg} / \mathrm{L}$, milligrams per liter; $\mathrm{kg} / \mathrm{mo}$, kilograms per month; $\mathrm{g} / \mathrm{m}^{2} / \mathrm{mo}$, gram per square meter per month; --, no data]

\begin{tabular}{|c|c|c|c|c|c|c|c|c|c|}
\hline Month & $\begin{array}{l}\text { Average } \\
\text { stream } \\
\text { discharge } \\
\left(\mathrm{ft}^{3} / \mathrm{s}\right)\end{array}$ & $\begin{array}{l}\text { Average } \\
\text { total } \\
\text { nitrogen } \\
\text { concen- } \\
\text { tration }^{1,2} \\
(\mathrm{mg} / \mathrm{L} \text { as } \mathrm{N})\end{array}$ & $\begin{array}{l}\text { Average } \\
\text { total } \\
\text { phosphorus } \\
\text { concen- } \\
\text { tration }{ }^{2} \\
\text { (mg/L as } \mathrm{P} \text { ) }\end{array}$ & $\begin{array}{l}\text { Total } \\
\text { nitrogen } \\
\text { load } \\
\text { site } 500^{3} \\
(\mathrm{~kg} / \mathrm{mo})\end{array}$ & $\begin{array}{l}\text { Total } \\
\text { nitrogen } \\
\text { load } \\
\text { site } 500^{4} \\
(\mathrm{~kg} / \mathrm{mo})\end{array}$ & $\begin{array}{l}\text { Total } \\
\text { phos- } \\
\text { phorus } \\
\text { load } \\
\text { site } 500^{3} \\
(\mathrm{~kg} / \mathrm{mo})\end{array}$ & $\begin{array}{l}\text { Nitrogen } \\
\text { loading to } \\
\text { Steilacoom } \\
\text { Lake }^{3,5} \\
\left(\mathrm{~g} / \mathrm{m}^{2} / \mathrm{mo}\right)\end{array}$ & $\begin{array}{l}\text { Nitrogen } \\
\text { loading to } \\
\text { Steilacoom } \\
\text { Lake }{ }^{4,5} \\
\left(\mathrm{~g} / \mathrm{m}^{2} / \mathrm{mo}\right)\end{array}$ & $\begin{array}{l}\text { Phosphorus } \\
\text { loading to } \\
\text { Steilacoom } \\
\text { Lake } \mathrm{e}^{3,5} \\
\left(\mathrm{~g} / \mathrm{m}^{2} / \mathrm{mo}\right)\end{array}$ \\
\hline \multicolumn{10}{|c|}{$\underline{1991}$} \\
\hline January & 65.8 & $2.4 \quad(5)$ & 0.02 & 12,000 & 10,000 & 120 & 9.4 & 8.3 & 0.09 \\
\hline February & 84.2 & $2.2^{6}(4)$ & $.04 \quad(4)$ & 13,000 & 13,000 & 230 & 9.9 & 9.9 & .18 \\
\hline March & 92.9 & $2.0 \quad(5)$ & $.04(5)$ & 14,000 & 16,000 & 250 & 11 & 12 & .20 \\
\hline June & 34.8 & $2.1 \quad(1)$ & $.02(1)$ & 5,400 & 4,900 & 51 & 4.1 & 3.9 & .04 \\
\hline August & 10.8 & $1.5 \quad(2)$ & $.04 \quad(2)$ & 1,200 & 1,300 & 29 & 0.93 & 1.4 & .02 \\
\hline September & 6.33 & 1.5 & .02 (3) & 700 & 690 & 9 & 0.54 & 0.53 & .01 \\
\hline October & 3.68 & $2.4(1)$ & $.11(1)$ & 670 & 380 & 31 & 0.52 & 0.29 & .02 \\
\hline November & 8.66 & $0.9^{6}(1)$ & $.04(2)$ & 580 & 1,000 & 25 & 0.44 & 0.77 & .02 \\
\hline \multicolumn{10}{|c|}{$\underline{1992}$} \\
\hline January & 27.1 & $1.8(8)$ & $.07(8)$ & 3.700 & 3,900 & 150 & 2.9 & 3.1 & .11 \\
\hline February & 64.8 & $2.1 \quad(4)$ & $0 \quad$ (4) & 9,500 & 9,600 & 170 & 7.4 & 7.6 & .14 \\
\hline March & 38.0 & $2.0^{6}(1)$ & -- & 5,800 & 5,600 & -- & 4.5 & 4.4 & -- \\
\hline April & 38.2 & 1.9 (1) & $.03 \quad(1)$ & 5,300 & 5,500 & 84 & 4.1 & 4.3 & .06 \\
\hline
\end{tabular}
total)

${ }^{1}$ Concentration of total nitrogen estimated as (Nitrite + Nitrate, $\mathrm{mg} / \mathrm{L}$ as N, dissolved) + (Ammonia +Organic Nitrogen, $\mathrm{mg} / \mathrm{L}$ as N,

${ }^{2}$ Number in parentheses indicates total number of samples upon which average is based.

${ }^{3}$ Load estimated from equation 2.

${ }^{4}$ Load estimated from equation 4.

${ }^{5}$ Area of Steilacoom Lake $=1.3 \times 10^{6} \mathrm{~m}^{2}$ (Bortleson and others, 1976).

${ }^{6}$ Includes one ammonia + organic nitrogen concentration that was less than the laboratory reporting limit; this concentration was arbitrarily assigned a value of $0.1 \mathrm{mg} / \mathrm{L}$, one-half the laboratory reporting limit. 


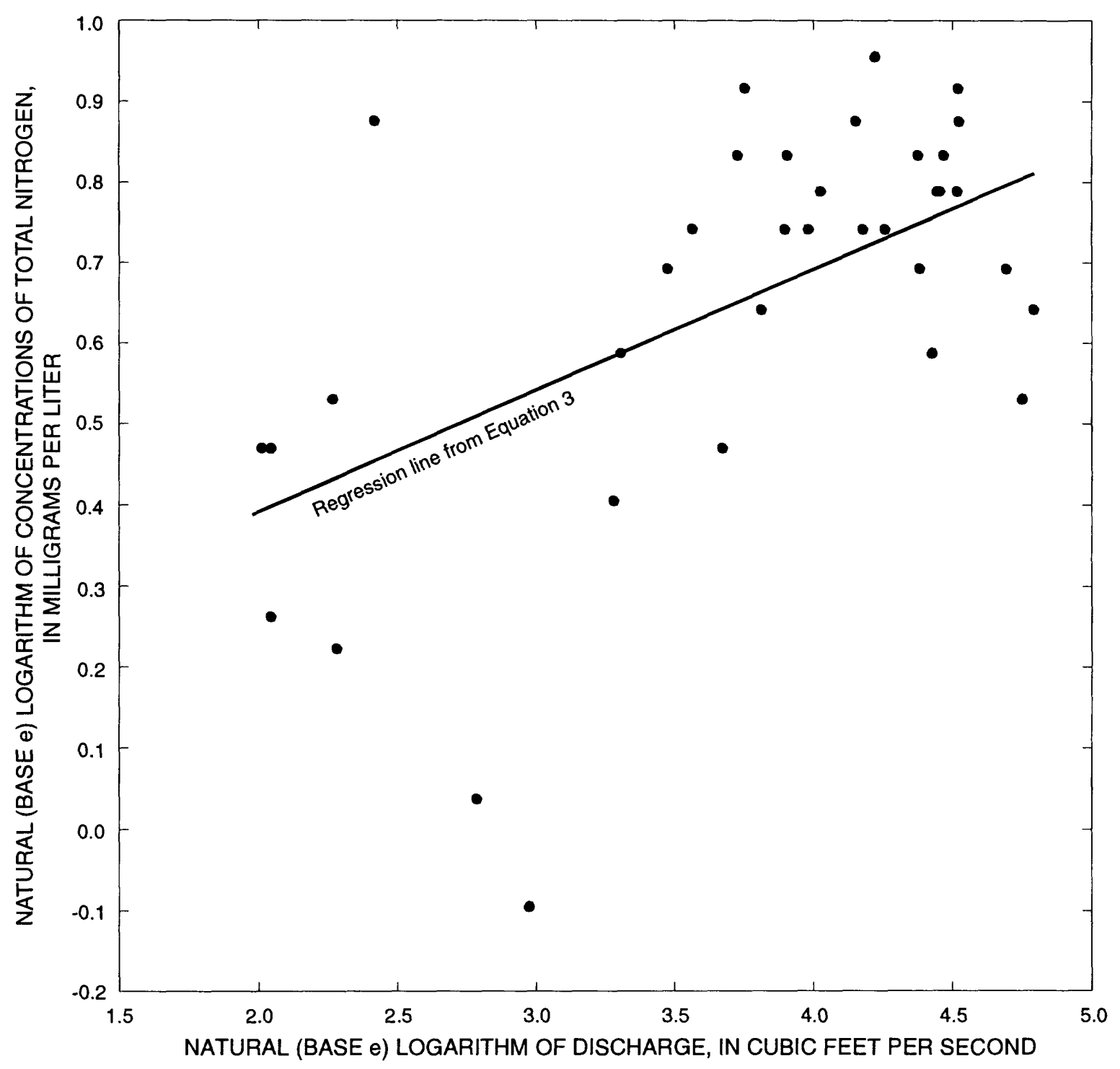

Figure 38.--Comparison of discharge and concentrations of total nitrogen at site 500, Lower Clover Creek subbasin, 1991-92. 


\section{Washington State Water-Quality Standards}

As a final means of assessing overall water quality in the Clover Creek Basin, data from the current study were compared with the water-quality standards set forth by Ecology (1992) for dissolved oxygen, fecal coliform, ammonia, copper, lead, and zinc. For dissolved oxygen and fecal coliform, separate criteria are written for Class A (excellent), Class B (good), and Class C (fair) streams.

Although only a limited number of dissolved-oxygen data were collected, concentrations less than the criterion for Class A streams (greater than $8.0 \mathrm{mg} / \mathrm{L}$ of dissolved oxygen) were measured at sites 330 and 480 . Dissolvedoxygen concentrations less than the criteria for both Class $\mathrm{A}$ and Class B streams (greater than $8.0 \mathrm{mg} / \mathrm{L}$ and greater than $6.5 \mathrm{mg} / \mathrm{L}$, respectively) were measured at sites 355 and 500. All sites met the criterion for Class $C$ streams (greater than $4 \mathrm{mg} / \mathrm{L}$ of dissolved oxygen).

Ecology's criteria for fecal coliform organism levels are based on geometric mean values of colony counts. In order to compare data from the current study with these criteria, geometric means of fecal coliform colony counts were calculated for each site using all available data, excluding non-ideal colony counts. Sites 360 and 480 met the fecal coliform criterion for Class A streams and sites 330,452 , and 460 met the fecal coliform criterion for Class B streams. Counts at all other sites exceeded the criteria for Class A, Class B, and Class C streams.

Toxic substances criteria for ammonia, copper, lead, and zinc are expressed by Ecology as average dissolved concentrations "not to be exceeded more than once every three years on the average" (1992, p. 6). Acute toxicity criteria are based on 1-hour average concentrations, and chronic toxicity criteria are based on 4-day average concentrations. Because only instantaneous concentration data were collected during this study, direct comparisons with these criteria are considered to be only approximate. Furthermore, a value for water hardness is necessary to calculate the toxicity criteria for heavy metals because their toxicities are dependent on the presence of calcium and magnesium ions (Prosi, 1979). Because no waterhardness data were collected during the current study, the average hardness of 35 samples collected at historical site 600 from 1962 through $1965(36 \mathrm{mg} / \mathrm{L}$, as calcium carbonate) was used to calculate the toxicity criteria for copper, lead, and zinc. The ammonia toxicity criteria, which are dependent upon water temperature and $\mathrm{pH}$, were not exceeded at any of the sites over the course of the current study. No copper or lead concentrations greater than the acute criteria were measured over the course of the study.
One copper concentration greater than the chronic criterion was measured at site 500; this concentration did not exceed the acute copper criterion. Lead concentrations greater than the chronic criterion were measured at sites $365,400,430$, and 500 , but none of these concentrations exceeded the acute lead criterion. It should be noted, however, that the chronic criterion for lead is less than the laboratory reporting limit for the method employed for lead analyses. Two zinc concentrations that exceeded both the chronic and acute criteria were measured, one at site 395 and one at site 400 . (As indicated by table 4 , no samples for metals analyses were collected at site 360 .)

\section{ADDITIONAL DATA NEEDED FOR NUMERICAL MODELING}

The data collected over the course of this study provide an understanding of the influence of land use and basin characteristics on surface-water quality within the basin. These data also provide insight into the complex nature of the processes and constituent sources governing water quality in the basin and lead to the identification of specific additional data that would be needed to successfully apply and calibrate a numerical water-quality model to the basin.

In many cases, changes in water quality observed along streams could not be fully accounted for with available data. It is likely that these changes are at least partially due to effluent from the large number of stormwater outfalls that discharge directly into Clover Creek and its tributaries (fig. 5). Although the quantity of water entering streams from these sources may be negligible relative to total stream discharge, water-quality characteristics observed in the two developed catchment areas (sites 340 and 380) showed that surface runoff from developed areas commonly contains high concentrations of many constituents of interest. Characterization of the discharge and quality of this effluent is therefore necessary to quantitatively model changes in water quality along Clover Creek and its tributaries.

Another important aspect of the system that is currently not well understood is the contribution of ground water. Although the data indicate that interaction between surface and ground water is substantial in the Upper Clover Creek subbasin, ground-water data are not available to quantify this relation. A quantitative understanding of this interaction is necessary to model water quality accurately and would require characterization of groundwater quality and an assessment of local ground- water flow directions. Because the soils in this area are highly permeable, the local ground-water flow regime may 
change not only seasonally, but also in response to individual storms. For example, the base-flow component of stream discharge may come from relatively deep ground water, whereas rapid infiltration of precipitation during storms may promote the displacement of shallow ground water toward streams. If this is true, different parts of the ground-water system contribute to streamflow at different times, and this may result in changes in water quality because the different ground-water flow paths intersect different sources. Local sources, such as on-site waste-disposal systems, drywells, and fertilizers, are likely to affect the quality of the shallow ground-water system, whereas deeper ground water may be affected by more distant, long-term sources, such as landfills. The fact that differences in water quality between base flow and storm flow are not apparent from currently available data is not necessarily an indication that differences are not present, because the constituents examined during the current study are likely common to a wide variety of subsurface sources. Nests of shallow piezometers located near the stream or within the streambed would provide valuable information on both the local flow regime and the water quality at the interface between the ground- and surfacewater systems. In addition, methods for distinguishing among nutrient sources, such as the isotopic or boronto-chloride methods discussed below, could be applied to the study basin. These methods, coupled with the careful choice of additional target water-quality constituents, could improve understanding of the effects of ground water on surface-water quality.

Accurate numerical simulation of nutrient transport within streams requires a quantitative understanding of nutrient sources. In addition to quantifying the magnitudes of the contributions from different sources, an understanding of the location and nature of the source is critical if transport processes are to be described and simulated correctly. Differentiating among sources is particularly important for assessing the effects of current land use and land-use changes on water quality. Concentration data alone are not sufficient to assess the relative contributions from the variety of sources that likely contribute nutrients to Clover Creek and its tributaries. One method to identify sources of nitrate involves the stable isotopes of nitrogen. By determining the isotopic composition of nitrate nitrogen, several investigators (for example, Heaton, 1986; Aravena, Evans, and Cherry, 1993; Komor and Anderson, 1993) have successfully identified sources of nitrate. Gerritse, Barber, and Adeney (1990) used the ratio of boron to chloride concentrations to assist in identifying areas in which waste-disposal systems were a significant source of water-quality constituents. Elevated chloride concentrations, which result from a wide variety of sources associated with land development, are characteristic of most developed areas. In contrast, elevated boron concentrations commonly result from laundry detergents and can therefore be attributed specifically to domestic waste water. As a result, Gerritse, Barber, and Adeney (1990) found that a relatively high boron-to-chloride ratio implicated residential waste water as a source of water-quality constituents. Furthermore, because the borate ion tends to be much more mobile than the phosphate ion (Gerritse, Barber, and Adeney, 1990), boron concentrations can provide additional insights that may be masked by the retardation of phosphate.

More detailed characterization of seasonal variations in water quality and the changes in constituent concentrations that take place during individual storms would also improve the accuracy of numerical-model simulations of water quality. Most of the data collected during the current study were collected during the winter months. Collecting additional data during the spring, summer, and fall would allow a more detailed assessment of seasonal water-quality patterns. Additional data from the initial phases of storms could more clearly reveal the effects of rainfall on water quality. Although data are currently available from several winter storms, they are generally not available from the earliest phase of the storms because of the time involved in preparing to collect samples once a storm begins. Because runoff during the first minutes or hours of storms is sometimes characterized by large, short-term increases in the concentrations of some constituents, automated monitors capable of collecting and storing samples from the earliest moments of a storm would provide valuable additional data for calibration of a numerical model. The benefit of automated monitors is demonstrated by the specific conductance and discharge data from the monitors at sites 355 and 500 (figs. 11 and 29), which indicate that specific conductance decreases considerably in response to increased stream discharge during storms. However, because these decreases take place during the earliest part of the storm and are very short term, samples collected manually from these sites do not reveal the magnitude of this response.

Including Spanaway and Tule Lakes in a numerical water-quality model of the basin would likely lead to a clearer understanding of the effects of these lakes on downstream water quality. Incorporating these effects would require chemical characterization of water in the lakes. Additional sampling at the lake inflows and at various locations within the lakes would not only allow development of a more accurate model of downstream water quality, but would also provide insights into potential water-quality problems within the lakes. 
Finally, it is apparent that water quality at all of the primary sampling sites discussed in this report has been affected, to some degree, by land-use practices. Comparison of available data with those from additional sites unaffected by urbanization would help to define the magnitude of the effects of urbanization at various sites. Although site 365 can be considered as relatively pristine, the limited data collected at secondary sites 325 , located near the headwaters of Clover Creek, and 448, located upstream of the inlet to Spanaway Lake (fig. 5, and Appendix A, tables A1, A2, and A3), suggest that additional sampling at these sites could provide valuable data for further assessing the degree of water-quality degradation in other parts of the basin.

\section{SUMMARY}

Land use in the Clover Creek Basin is currently varied, ranging from rural to commercial and industrial development. Urbanization is increasing, however, and has generated interest in the effects of changing land-use patterns on local water quality. To address these interests, water-quality and stream-discharge data were collected from 19 surface-water sites and 2 precipitation-collection sites over a 16-month period from January 1991 through April 1992. Data from 15 primary data-collection sites, 12 located on the principal streams of the basin and 3 located on the relatively minor outflows of small, well-characterized catchment areas, were used in conjunction with information on surficial geology, land-use practices, and waste-disposal methods to provide an understanding of the influence of land use and other basin characteristics on surface-water quality within the basin. The basin was divided into four drainage subbasins with dissimilar hydrogeologic, land-use, and water-quality characteristics. Surface-water quality observed at each of the 15 primary data-collection sites was explained in terms of the characteristics of the subbasins and catchment areas.

In general, surface-water quality throughout the basin reflects the influence of increasing urbanization. However, due to differences in surficial geologic materials and varying degrees of urbanization across the basin, waterquality constituents in different parts of the basin reach surface water through different transport mechanisms. These differences result in dissimilarities in the temporal distributions of water-quality constituents at various sites. Varying degrees of urbanization and differences in waste-disposal practices across the basin result in a nonuniform spatial distribution of water-quality constituents. Finally, the presence of lakes appears to mask the effects of urbanization, probably because many water-quality constituents tend to accumulate within the lakes rather than to be transported downstream.

The water-quality and stream-discharge data from the Upper Clover Creek subbasin indicate that significant interaction occurs between ground and surface water in this area. This interaction can be attributed to the highly permeable glacial outwash materials that underlie the subbasin. The upstream part of Clover Creek appears to be a ground-water discharge area, and as a result, surface-water quality there is subject to both the attenuating influence of flow through porous media and the deleterious effects of subsurface sources of water-quality constituents such as on-site waste-disposal systems, drywells, and even landfills. Previous investigations found that ground-water quality in the basin has been negatively influenced by increased urbanization, specifically on-site waste-disposal systems and drywells, and data collected during the current study indicate that because ground water discharges to Clover Creek, surface water is being affected in a similar manner.

At the three sampling sites in the Spanaway subbasin, specific conductance, fecal bacteria counts, and concentrations of nutrients and suspended sediment were low relative to other parts of the basin. However, these low levels can be attributed to the presence of Spanaway and Tule Lakes rather than to a lack of sources of these constituents. Concentrated land development in the lower part of the subbasin and the continued use of on-site waste-disposal systems undoubtedly contribute substantial quantities of nutrients, metals, and other water-quality constituents to surface water, but low velocities and long residence times within the lakes promote mixing of dissolved species and settling of suspended materials. In addition, biological processes within the lakes utilize available nutrients, converting them to biomass. As a result of these processes, the lakes tend to accumulate both nutrients and constituents such as metals that are associated with solid-phase materials.

In the North Fork subbasin, water quality and the hydrologic response to rainfall were shown to be strongly affected by the low permeability of the glacial till that underlies the subbasin. Because the glacial till inhibits infiltration, storm runoff follows surface or shallow subsurface paths and reaches streams quickly. This rapid runoff results in abrupt increases in stream discharge in response to rainfall. In addition, water-quality constituents that have accumulated on surfaces between storms are washed off during storms, and fecal bacteria counts and 
concentrations of suspended sediment, ammonia, organic nitrogen, and phosphorus increase along with stream discharge.

The Lower Clover Creek subbasin receives flow from the other three subbasins and is thus an integration of the entire basin. However, numerous stormwater outfalls also discharge into lower Clover Creek. During storms, the large changes in stream discharge and water quality seen in the North Fork subbasin, coupled with discharge from these outfalls, dominate streamflow and water quality, particularly in the upper part of the subbasin at site 430 .

The changes in water quality that result from urbanization are most clearly manifested by data collected from the three catchment areas. Specific conductance, suspended sediment, chloride, dissolved nitrite plus nitrate, ammonia, phosphorus, and fecal bacteria are all elevated in runoff from the developed areas relative to that from the rural catchment area. These differences are particularly evident during rainfall, reflecting the strong influence of impervious surfaces associated with urbanization.

Monthly loads of nitrogen and phosphorus entering Steilacoom Lake from Clover Creek were estimated from data collected at site 500. Loads were estimated as the product of average monthly stream discharge and average monthly concentrations of total nitrogen and total phosphorus. A regression model was also used to estimate monthly nitrogen loads, but because of the weak relation between stream discharge and nitrogen concentrations, estimates from the regression model were similar to those from simple calculations based on monthly average values of discharge and concentration. Because the correlation between phosphorus concentrations and discharge was not statistically significant $(p=0.97)$, the regression model was not used to estimate phosphorus loads. The data indicate that the dependence of nutrient concentrations on stream discharge is weak to nonexistent and that changes in the loading rates to Steilacoom Lake from Clover Creek are therefore governed primarily by changes in stream discharge rather than in nutrient concentrations.

Data collected over the course of the study were examined in the context of the Washington State Department of Ecology water-quality standards for dissolved oxygen, fecal coliform, ammonia, copper, lead, and zinc. Concentrations of dissolved oxygen that did not meet the criterion for Class A streams were measured at sites 330 and 480 , and concentrations that did not meet the criteria for either Class A or B streams were measured at sites 355 and 500 . Fecal coliform colony counts that exceeded the criteria for stream Classes A, B, and C were measured at all sites except sites 330, 452, and 460, which met the criterion for Class B streams, and sites 360 and 480, which met the criterion for Class A streams. Comparisons of instantaneous concentrations of ammonia, copper, lead, and zinc collected in this study with the acute and chronic water-quality criteria are considered to be only approximate because the acute and chronic toxicity criteria are based on 1-hour and 4-day average concentrations, respectively. The ammonia toxicity criteria were not exceeded at any of the sites; the chronic criterion for copper was exceeded once at site 500; the chronic criterion for lead was exceeded at sites 365,400,430, and 500; and both the chronic and acute criteria for zinc were exceeded, once at site 395 and once at site 400 .

The understanding provided by this study of the influence of land use and other basin characteristics on surfacewater quality in the Clover Creek Basin indicates that additional data would provide enhanced understanding of the biological, chemical, and transport processes and constituent sources governing water quality in the basin. Specifically, the accuracy of numerical simulations of water quality in the Clover Creek Basin could be improved considerably by collection of data to (1) quantify the discharge and chemical nature of effluent from stormwater outfalls that discharge directly into Clover Creek and its tributaries, (2) characterize ground-water quality and subsurface flow paths, especially in the Upper Clover Creek subbasin, (3) differentiate various sources of nutrients, (4) further characterize temporal variations in water quality that occur both seasonally and over the course of individual storms, (5) quantify the changes in water quality that occur during transport through lakes, and (6) further characterize water quality at relatively pristine sites (for example, secondary sites 325 and 448).

\section{REFERENCES}

Anderson, D.G., 1970, Effects of urban development on floods in Northern Virginia: U.S. Geological Survey Water-Supply Paper 2001-C, 22 p.

Aravena, R., Evans, M.L., and Cherry, J.A., 1993, Stable isotopes of oxygen and nitrogen in source identification of nitrate from septic systems: Ground Water, vol. 31, no. 2, p. 180-185.

Bedient, P.B., Harned, D.A., and Characklis, W.G., 1978, Stormwater analysis and prediction in HoustonJournal of the Environmental Engineering Division: American Society of Civil Engineers, vol. 104, no. EE6, p. 1087-1100. 
Blumberg, M.S., and Bell, J.M., 1984, The effect of various hydrologic parameters on the quality of stormwater runoff from a West Lafayette, Indiana urban watershed: West Lafayette, Indiana, Purdue University Water Resources Research Center, Technical Report no. 162, 121 p.

Britton, L.J., and Greeson, P.E., 1987, Methods for collection and analysis of aquatic biological and microbiological samples: U.S. Geological Survey Techniques of Water-Resources Investigations, book 5, chapter A4, $363 \mathrm{p}$.

Brown and Caldwell Consultants, 1985, Clover/Chambers Creek geohydrologic study for Tacoma-Pierce County Health Department: Seattle, Wash., Final Report, unpaginated.

1991, Clover/Chambers Creek basin ground water management program: Seattle, Wash., Final Report, unpaginated.

Cohn, T.A., Caulder, D.L., Gilroy, E.J., Zynjuk, L.D., and Summers, R.M., 1992, The validity of a simple statistical model for estimating fluvial constituent loads-An empirical study involving nutrient loads entering Chesapeake Bay: Water Resources Research, vol. 28 , no. 9 , p. $2353-2363$.

Driver, N.E., and Tasker, G.D., 1988, Techniques for estimation of storm-runoff loads, volumes, and selected constituent concentrations in urban watersheds in the United States: U.S. Geological Survey Open-File Report 88-191, 80 p.

Edwards, T.K., and Glysson, D.G., 1988, Field methods for measurement of fluvial sediment: U.S. Geological Survey Open-File Report 86-531, 118 p.

Fishman, M.J., and Friedman, L.C., eds., 1989, Methods for determination of inorganic substances in water and fluvial sediments: U.S. Geological Survey Techniques of Water-Resources Investigations, book 5 , chapter A1, $546 \mathrm{p}$.

Gerritse, R.G., Barber, C., and Adeney, J.A., 1990, The impact of residential urban areas on groundwater quality-Swan Coastal Plain, Western Australia: Commonwealth Scientific and Industrial Research Organization Water Resources Series no. 3, 27 p.
Griffin, D.M., Jr., Grizzard, T.J., Randall, C.W., and Hartigan, J.P., 1978, An examination of nonpoint pollution export from various land use types: Proceedings of the International Symposium on Urban Water Management, Lexington, Kentucky, July 24-27, p. 119-127.

Heaton, T.H.E., 1986, Isotopic studies of nitrogen pollution in the hydrosphere and atmosphere-A review: Chemical Geology (Isotope Geoscience Section), vol. 59, p. 87-102.

Helsel, D.R., Kim, J.I., Grizzard, T.J., Randall, C.W., and Hoehn, R.C., 1979, Land use influences on metals in storm drainage: Journal of the Water Pollution Control Federation, vol. 51, no. 4, p. 709-717.

Komor, S.C., and Anderson, H.W., 1993, Nitrogen isotopes as indicators of nitrate sources in Minnesota sand-plain aquifers: Ground Water, vol. 31, no. 2, p. 260-269.

Littler, J.D., Aden, J.T., and Johnson, A.F., 1981, Survey of groundwater and surface water quality for the Chambers Creek/Clover Creek drainage basin, Pierce County: Washington State Department of Social and Health Services, $103 \mathrm{p}$.

Mastin, M.C., 1996, Surface-water hydrology and runoff simulations for the three basins in Pierce County, Washington: U.S. Geological Survey Water-Resources Investigation Report 95-4068, $148 \mathrm{p}$.

McCarthy, J.F., Williams, T.M., Liang, Liyuan, Jardine, P.M., Jolley, L.W., Taylor, D.L., Palumbo, A.V., and Cooper, L.W., 1993, Mobility of natural organic matter in a sandy aquifer: Environmental Science and Technology, vol. 27 , no. 4, p. 667-676.

Olivieri; V.P., 1980, Microorganisms from nonpoint sources in the urban environment, in Overcash, M.R., and Davidson, J.M., eds., Environmental impact of nonpoint source pollution: Ann Arbor, Michigan, Ann Arbor Science Publishers, 449 p.

Omernik, J.M., 1976, The influence of land use on stream nutrient levels: U.S. Environmental Protection Agency Report EPA-600/3-76-014, 106 p. 
Prosi, F., 1979, Heavy metals in aquatic organisms, in Forstner, U., and Wittmann, G.T.W., Metal pollution in the aquatic environment: Berlin, Springer-Verlag, $486 \mathrm{p}$.

Rimer, A.E., Nissen, J.A., and Reynolds, D.E., 1978, Characterization and impact of stormwater runoff from various land cover types: Journal of the Water Pollution Control Federation, vol. 50, no. 2, p. 252-264.

Savini, John, and Kammerer, J.C., 1961, Urban growth and the water regimen: U.S. Geological Survey Water-Supply Paper 1591-A, 43 p.

Seaburn, G.E., 1969, Effects of urban development on direct runoff to East Meadow Brook, Nassau County, Long Island, New York: U.S. Geological Survey Professional Paper 627-B, 14 p.

Severson, R.C., Wilson, S.A., and McNeal, J.M., 1987, Analyses of bottom material collected at nine areas in the Western United States for the Department of Interior irrigation drainage task group: U.S. Geological Survey Open-File Report 87-490, 24 p.
Snyder, D.T., Morgan, D.S., and McGrath, T.S., 1994, Estimation of ground-water recharge from precipitation, runoff into drywells, and on-site waste-disposal systems in the Portland Basin, Oregon and Washington: U.S. Geological Survey Water-Resources Investigations Report 92-4010, 34 p.

U.S. Environmental Protection Agency, 1983, Results of the nationwide urban runoff program, vol. I: Washington, D.C., Government Printing Office, unpaginated.

Washington State Department of Ecology, 1992, Water quality standards for surface waters of the State of Washington: Washington Administrative Code, chap. 173-201A, $14 \mathrm{p}$.

Wershaw, R.L., Fishman, M.J., Grabbe, R.R., and Lowe, L.E., eds., 1987, Methods for the determination of organic substances in water and fluvial sediments: U.S. Geological Survey Techniques of WaterResources Investigations, book 5, chap. A3, 80 p. 
Appendix A.--Data Tables 
Table A1.--Discharge, specific conductance, suspended-sediment, chloride, sulfate, and fluoride data for the Clover Creek Basin, 1991-92

[ft ${ }^{3} / \mathrm{s}$, cubic feet per second; $\mu \mathrm{S} / \mathrm{cm}$, microsiemens per centimeter; $\mathrm{mg} / \mathrm{L}$, milligrams per liter; <, less than; --, no data]

\begin{tabular}{|c|c|c|c|c|c|c|c|c|}
\hline $\begin{array}{l}\text { Site } \\
\text { num- } \\
\text { ber }^{1}\end{array}$ & Date & Time & $\begin{array}{l}\text { Dis- } \\
\text { charge, } \\
\left(\mathrm{ft}^{3} / \mathrm{s}\right)\end{array}$ & $\begin{array}{l}\text { Spe- } \\
\text { cific } \\
\text { con- } \\
\text { duc- } \\
\text { tance } \\
(\mu S / c m)\end{array}$ & $\begin{array}{l}\text { Sedi- } \\
\text { ment, } \\
\text { sus- } \\
\text { pended } \\
(\mathrm{mg} / \mathrm{L})\end{array}$ & $\begin{array}{l}\text { Chlo- } \\
\text { ride, } \\
\text { dis- } \\
\text { solved } \\
(\mathrm{mg} / \mathrm{L} \\
\text { as } \mathrm{Cl})\end{array}$ & $\begin{array}{l}\text { Sulfate, } \\
\text { dis- } \\
\text { solved } \\
(\mathrm{mg} / \mathrm{L} \\
\left.\text { as } \mathrm{SO}_{4}\right)\end{array}$ & $\begin{array}{l}\text { Fluo- } \\
\text { ride, } \\
\text { dis- } \\
\text { solved } \\
\text { (mg/L } \\
\text { as F) }\end{array}$ \\
\hline \multirow[t]{3}{*}{325} & $06-26-91$ & 0815 & 0.9 & 137 & -- & 4.9 & -- & -- \\
\hline & $03-24-92$ & 1250 & -- & 145 & -- & 7.5 & -- & -- \\
\hline & $04-21-92$ & 1045 & 1.0 & 142 & -- & 4.7 & -- & -- \\
\hline \multirow[t]{23}{*}{330} & $01-23-91$ & 0845 & 8.9 & 163 & 4 & 12 & 6.3 & $<0.1$ \\
\hline & $03-02-91$ & 1120 & 11 & 150 & -- & 9.1 & -- & -- \\
\hline & $06-11-91$ & 1445 & 6.6 & 155 & -- & 6.7 & -- & -- \\
\hline & $06-26-91$ & 0850 & 6.1 & 153 & -- & 7.7 & -- & -- \\
\hline & $08-27-91$ & 1020 & 3.3 & 152 & -- & 7.4 & -- & - \\
\hline & 09-04-91 & 0940 & 3.3 & 151 & -- & 5.8 & -- & - \\
\hline & 09-04-91 & 1250 & 3.2 & 151 & -- & -- & -. & -- \\
\hline & 09-04-91 & 1555 & 3.2 & 150 & -- & 6.5 & -- & -- \\
\hline & 09-04-91 & 1835 & 3.2 & 151 & -- & -- & -- & -- \\
\hline & 09-04-91 & 2040 & 3.3 & 151 & -- & 6.5 & -- & -- \\
\hline & 09-04-91 & 2345 & 3.3 & 151 & -- & -- & -- & -- \\
\hline & $09-05-91$ & 0245 & 3.3 & 147 & -- & -- & -- & -- \\
\hline & $11-23-91$ & 1630 & 2.2 & 154 & 0 & 15 & -- & -- \\
\hline & $01-10-92$ & 1230 & 3.0 & 149 & 3 & 7.1 & -- & -- \\
\hline & $01-23-92$ & 1500 & 3.2 & 147 & 1 & 7.8 & -- & -- \\
\hline & $01-25-92$ & 1100 & 3.2 & 148 & 2 & 6.8 & -- & -- \\
\hline & $01-28-92$ & 1310 & 5.2 & 135 & 4 & 6.2 & -- & -- \\
\hline & $02-04-92$ & 1230 & 8.4 & 154 & 2 & 11 & -- & -- \\
\hline & $02-19-92$ & 1320 & 6.6 & 160 & 2 & 10 & -- & -- \\
\hline & $02-21-92$ & 1400 & 7.1 & 154 & 2 & 11 & -- & -- \\
\hline & $02-27-92$ & 0915 & 7.3 & 164 & 1 & 11 & -- & -- \\
\hline & $03-24-92$ & 1350 & -- & 150 & -- & 7.3 & -- & -- \\
\hline & $04-21-92$ & 1130 & -- & 149 & -- & 6.6 & -- & - \\
\hline \multirow[t]{2}{*}{335} & $06-26-91$ & 0940 & 19 & 150 & -- & 6.9 & -- & -- \\
\hline & $04-21-92$ & 1100 & 16 & 155 & -- & 6.3 & -- & -- \\
\hline \multirow[t]{9}{*}{340} & $01-31-91$ & 1215 & 0.07 & 101 & 78 & 6.3 & 8.3 & $<0.1$ \\
\hline & $02-02-91$ & 2140 & 0.75 & 100 & 56 & 7.5 & 6.0 & $<0.1$ \\
\hline & $02-03-91$ & 1030 & 0.16 & 129 & 29 & 9.3 & 7.8 & $<0.1$ \\
\hline & $03-02-91$ & 0500 & 0.03 & 140 & 10 & 8.7 & -- & -- \\
\hline & $03-02-91$ & 0845 & 0.08 & 125 & 28 & 8.4 & -- & $-\cdot$ \\
\hline & $03-02-91$ & 0855 & 0.08 & 102 & 71 & 5.2 & -- & -- \\
\hline & $03-02-91$ & 1540 & 0.20 & 107 & 35 & 5.2 & -- & -- \\
\hline & $03-03-91$ & 0650 & 0.10 & 119 & 22 & 5.9 & -- & -- \\
\hline & $01-23-92$ & 1430 & 0.04 & 186 & 4 & 15 & -- & -- \\
\hline
\end{tabular}


Table A1.--Discharge, specific conductance, suspended-sediment, chloride, sulfate, and fluoride data for the Clover Creek Basin, 1991-92--Continued

\begin{tabular}{|c|c|c|c|c|c|c|c|c|}
\hline $\begin{array}{l}\text { Site } \\
\text { num- } \\
\text { ber }{ }^{1}\end{array}$ & Date & Time & $\begin{array}{l}\text { Dis- } \\
\text { charge, } \\
\left(\mathrm{ft}^{3} / \mathrm{s}\right)\end{array}$ & $\begin{array}{l}\text { Spe- } \\
\text { cific } \\
\text { con- } \\
\text { duc- } \\
\text { tance } \\
(\mu \mathrm{S} / \mathrm{cm})\end{array}$ & $\begin{array}{l}\text { Sedi- } \\
\text { ment, } \\
\text { sus- } \\
\text { pended } \\
(\mathrm{mg} / \mathrm{L})\end{array}$ & $\begin{array}{l}\text { Chlo- } \\
\text { ride, } \\
\text { dis- } \\
\text { solved } \\
(\mathrm{mg} / \mathrm{L} \\
\text { as } \mathrm{Cl})\end{array}$ & $\begin{array}{l}\text { Sulfate, } \\
\text { dis- } \\
\text { solved } \\
\text { (mg/L } \\
\text { as } \mathrm{SO}_{4} \text { ) }\end{array}$ & $\begin{array}{l}\text { Fluo- } \\
\text { ride, } \\
\text { dis- } \\
\text { solved } \\
(\mathrm{mg} / \mathrm{L} \\
\text { as } \mathrm{F})\end{array}$ \\
\hline \multirow[t]{8}{*}{340} & $01-28-92$ & 1030 & 0.18 & 181 & 7 & 9.7 & -- & -- \\
\hline & $01-29-92$ & 0945 & 0.18 & 152 & 4 & 3.8 & -- & -- \\
\hline & $01-30-92$ & 0815 & 0.19 & 110 & 37 & 6.5 & -. & -- \\
\hline & $01-31-92$ & 0945 & 0.14 & 165 & 3 & 12 & -- & -- \\
\hline & $02-21-92$ & 0645 & 0.08 & 102 & 119 & 7.8 & -- & -- \\
\hline & $02-21-92$ & 1410 & 0.06 & 165 & 5 & 11 & -- & -- \\
\hline & $02-24-92$ & 0815 & 0.04 & 170 & 15 & 9.7 & -- & -- \\
\hline & $03-24-92$ & 0825 & 0.03 & 171 & -- & 12 & -- & $\cdots$ \\
\hline \multirow[t]{29}{*}{355} & $01-12-91$ & 1030 & 32 & 121 & 7 & 6.4 & 4.8 & $<0.1$ \\
\hline & $01-14-91$ & 0815 & 34 & 146 & -- & 6.9 & 4.6 & $<0.1$ \\
\hline & $01-23-91$ & 0745 & 25 & 160 & 1 & 8.3 & 5.9 & $<0.1$ \\
\hline & $02-03-91$ & 0930 & 29 & 129 & 3 & 6.9 & 4.9 & $<0.1$ \\
\hline & $02-04-91$ & 0940 & 30 & 137 & 2 & 6.7 & 5.7 & $<0.1$ \\
\hline & $02-06-91$ & 1145 & 29 & 150 & -- & 7.6 & -- & $<0.1$ \\
\hline & $03-01-91$ & 0820 & 32 & 154 & 1 & 5.2 & -- & -- \\
\hline & $03-02-91$ & 1140 & 35 & 141 & -- & 7.5 & -- & -- \\
\hline & $03-03-91$ & 0830 & 39 & 137 & -- & 7.6 & -- & -- \\
\hline & $03-04-91$ & 0900 & 42 & 135 & 3 & 7.9 & - & - \\
\hline & $03-13-91$ & 1315 & 38 & 147 & 1 & 7.5 & -- & -- \\
\hline & $06-11-91$ & 1345 & 17 & 147 & -- & 6.5 & -- & -- \\
\hline & $06-26-91$ & 1035 & 15 & 148 & -- & 6.7 & -- & - \\
\hline & $08-27-91$ & 0915 & 7.6 & 161 & -- & 8.7 & -- & -- \\
\hline & $09-04-91$ & 0850 & 7.3 & 160 & -- & 6.8 & -- & $\cdots$ \\
\hline & 09-04-91 & 1145 & 7.3 & 159 & -- & -- & -- & -- \\
\hline & $09-04-91$ & 1515 & 7.3 & 158 & -- & 7.2 & -- & -- \\
\hline & $09-04-91$ & 1815 & 7.3 & 157 & -- & -- & -- & -- \\
\hline & $09-04-91$ & 2015 & 7.3 & 157 & -- & 7.2 & -- & -- \\
\hline & 09-04-91 & 2320 & 7.2 & 159 & -- & -- & - & -- \\
\hline & $09-05-91$ & 0215 & 7.2 & 154 & -- & -- & -- & -- \\
\hline & $11-23-91$ & 1515 & 5.3 & 166 & 0 & 8.2 & -- & -- \\
\hline & $01-23-92$ & 1530 & 25 & 148 & 3 & 8.1 & -- & -- \\
\hline & $01-25-92$ & 1200 & 22 & 156 & 2 & 7.5 & -- & -- \\
\hline & $01-28-92$ & 1335 & 20 & 116 & 5 & 6.2 & -- & -- \\
\hline & $02-04-92$ & 1315 & 29 & 155 & 2 & 8.4 & -- & - \\
\hline & $02-21-92$ & 1300 & 25 & 140 & 5 & 8.4 & -- & -- \\
\hline & $03-24-92$ & 1440 & -- & 156 & -- & 7.4 & -- & -- \\
\hline & $04-21-92$ & 1210 & 15 & 154 & -- & 6.2 & -- & -- \\
\hline \multirow[t]{2}{*}{358} & $06-26-91$ & 1225 & 11 & 148 & -- & 6.8 & -- & -- \\
\hline & $04-21-92$ & 1230 & 13 & 152 & -- & 6.2 & -- & -- \\
\hline
\end{tabular}


Table A1.--Discharge, specific conductance, suspended-sediment, chloride, sulfate, and fluoride data for the Clover Creek Basin, 1991-92--Continued

\begin{tabular}{|c|c|c|c|c|c|c|c|c|}
\hline $\begin{array}{l}\text { Site } \\
\text { num- } \\
\text { ber }^{1}\end{array}$ & Date & Time & $\begin{array}{l}\text { Dis- } \\
\text { charge, } \\
\left(\mathrm{ft}^{3} / \mathrm{s}\right)\end{array}$ & $\begin{array}{l}\text { Spe- } \\
\text { cific } \\
\text { con- } \\
\text { duc- } \\
\text { tance } \\
(\mu \mathrm{S} / \mathrm{cm})\end{array}$ & $\begin{array}{l}\text { Sedi- } \\
\text { ment, } \\
\text { sus- } \\
\text { pended } \\
(\mathrm{mg} / \mathrm{L})\end{array}$ & $\begin{array}{l}\text { Chlo- } \\
\text { ride, } \\
\text { dis- } \\
\text { solved } \\
(\mathrm{mg} / \mathrm{L} \\
\text { as } \mathrm{Cl})\end{array}$ & $\begin{array}{l}\text { Sulfate, } \\
\text { dis- } \\
\text { solved } \\
(\mathrm{mg} / \mathrm{L} \\
\left.\text { as } \mathrm{SO}_{4}\right)\end{array}$ & $\begin{array}{l}\text { Fluo- } \\
\text { ride, } \\
\text { dis- } \\
\text { solved } \\
(\mathrm{mg} / \mathrm{L} \\
\text { as F) }\end{array}$ \\
\hline \multirow[t]{14}{*}{360} & $01-12-91$ & 1200 & 7.5 & 131 & 2 & 8.8 & 4.8 & $<0.1$ \\
\hline & $01-23-91$ & 1040 & 3.0 & 160 & -- & 8.5 & 6.4 & $<0.1$ \\
\hline & 02-03-91 & 1510 & 2.0 & 127 & -- & 7.1 & 5.2 & $<0.1$ \\
\hline & 02-04-91 & 0930 & 4.9 & 134 & 1 & 6.5 & 5.4 & $<0.1$ \\
\hline & $02-06-91$ & 1240 & 6.6 & 144 & 3 & 7.0 & 5.6 & $<0.1$ \\
\hline & $03-01-91$ & 1145 & 6.8 & 150 & -- & 9.1 & -- & -- \\
\hline & $03-02-91$ & 1210 & 8.1 & 144 & -- & 7.6 & -- & -- \\
\hline & 03-04-91 & 1145 & 17 & 134 & 1 & 7.5 & -- & .- \\
\hline & $06-11-91$ & 1535 & 0.3 & 145 & -- & 5.5 & -- & -- \\
\hline & $06-26-91$ & 1325 & 0.1 & 140 & -- & 6.7 & -- & - \\
\hline & $01-25-92$ & 1245 & 0.7 & 151 & -- & 7.9 & -- & -- \\
\hline & $02-04-92$ & 1315 & 5.9 & 147 & 4 & 8.4 & -- & -- \\
\hline & $03-24-92$ & 1250 & -- & 161 & -- & 4.9 & -- & -. \\
\hline & $04-21-92$ & 1255 & 4.3 & 148 & -- & 6.2 & -- & -- \\
\hline \multirow[t]{15}{*}{365} & $01-31-91$ & 1245 & 0.3 & 59 & 11 & 8.8 & 16 & $<0.1$ \\
\hline & $02-02-91$ & 2210 & 3.9 & 54 & 19 & 3.6 & 2.9 & $<0.1$ \\
\hline & $02-03-91$ & 0850 & -- & 65 & 5 & 3.0 & 1.9 & $<0.1$ \\
\hline & $02-04-91$ & 1140 & 1.2 & 64 & 1 & 4.4 & 3.3 & $<0.1$ \\
\hline & $03-01-91$ & 1215 & 0.1 & 61 & 9 & 5.0 & -- & -- \\
\hline & $03-02-91$ & 0540 & 0.7 & 64 & 5 & 3.5 & -- & -- \\
\hline & $03-02-91$ & 1520 & 1.0 & 58 & 14 & 3.0 & -- & - \\
\hline & $03-03-91$ & 0815 & 1.2 & 61 & -- & 3.1 & -- & - \\
\hline & 03-04-91 & 0945 & 1.5 & 59 & 4 & 3.1 & -- & - \\
\hline & $03-05-91$ & 1145 & 0.7 & 56 & - & 3.5 & -- & - \\
\hline & $01-10-92$ & 1320 & 0.1 & 78 & 4 & 5.8 & -- & -. \\
\hline & $01-22-92$ & 2035 & 0.1 & 74 & 5 & 7.4 & -- & -- \\
\hline & $01-23-92$ & 1130 & 0.7 & 68 & 8 & 5.6 & - & - \\
\hline & $01-24-92$ & 1030 & 0.5 & 73 & 3 & 7.3 & -- & - \\
\hline & $01-28-92$ & 0945 & 1.6 & 75 & 10 & 4.4 & -- & -- \\
\hline \multirow[t]{10}{*}{365} & $01-28-92$ & 1800 & 1.8 & 75 & 8 & 5.6 & -- & - \\
\hline & $01-29-92$ & 0900 & 1.2 & 77 & 4 & 5.0 & -- & -- \\
\hline & $01-31-92$ & 0900 & 1.7 & 75 & 2 & 5.3 & -- & -- \\
\hline & $02-04-92$ & 0945 & 0.3 & 73 & 11 & 6.8 & -- & -- \\
\hline & $02-19-92$ & 1225 & 0.4 & 66 & 25 & 5.1 & -- & -- \\
\hline & $02-21-92$ & 0730 & 1.0 & 71 & 19 & 6.2 & - & -- \\
\hline & $02-21-92$ & 1340 & 1.0 & 65 & 9 & 5.2 & -- & -- \\
\hline & $02-24-92$ & 0850 & 0.4 & 69 & 9 & 4.5 & -- & -- \\
\hline & $03-24-92$ & 0930 & 0.1 & 62 & -- & 5.2 & -- & -- \\
\hline & $04-21-92$ & 0845 & -- & 63 & -- & 3.5 & -- & -- \\
\hline
\end{tabular}


Table A1.--Discharge, specific conductance, suspended-sediment, chloride, sulfate, and fluoride data for the Clover Creek Basin, 1991-92--Continued

\begin{tabular}{|c|c|c|c|c|c|c|c|c|}
\hline $\begin{array}{l}\text { Site } \\
\text { num- } \\
\text { ber }^{1}\end{array}$ & Date & Time & $\begin{array}{l}\text { Dis- } \\
\text { charge, } \\
\left(\mathrm{ft}^{3} / \mathrm{s}\right)\end{array}$ & $\begin{array}{l}\text { Spe- } \\
\text { cific } \\
\text { con- } \\
\text { duc- } \\
\text { tance } \\
(\mu S / c m)\end{array}$ & $\begin{array}{l}\text { Sedi- } \\
\text { ment, } \\
\text { sus- } \\
\text { pended } \\
(\mathrm{mg} / \mathrm{L})\end{array}$ & $\begin{array}{l}\text { Chlo- } \\
\text { ride, } \\
\text { dis- } \\
\text { solved } \\
(\mathrm{mg} / \mathrm{L} \\
\text { as } \mathrm{Cl})\end{array}$ & $\begin{array}{l}\text { Sulfate, } \\
\text { dis- } \\
\text { solved } \\
(\mathrm{mg} / \mathrm{L} \\
\left.\text { as } \mathrm{SO}_{4}\right)\end{array}$ & $\begin{array}{l}\text { Fluo- } \\
\text { ride, } \\
\text { dis- } \\
\text { solved } \\
(\mathrm{mg} / \mathrm{L} \\
\text { as } \mathrm{F})\end{array}$ \\
\hline \multirow[t]{30}{*}{370} & $01-12-91$ & 1015 & 51 & 78 & 115 & 5.7 & 5.6 & $<0.1$ \\
\hline & 01-14-91 & 0910 & 11 & 93 & 4 & 4.6 & 4.8 & $<0.1$ \\
\hline & $01-23-91$ & 0910 & 6.5 & 89 & 12 & 7.2 & 7.2 & $<0.1$ \\
\hline & $02-01-91$ & 0830 & 8.2 & 98 & -- & 6.3 & 5.2 & $<0.1$ \\
\hline & $02-02-91$ & 2240 & 60 & 72 & 327 & 4.2 & 3.6 & $<0.1$ \\
\hline & $02-03-91$ & 0950 & 30 & 81 & 16 & 4.7 & 5.1 & $<0.1$ \\
\hline & $02-04-91$ & 1000 & 29 & 85 & 9 & 4.9 & 5.1 & $<0.1$ \\
\hline & $03-01-91$ & 0900 & 2.2 & 93 & 1 & 5.9 & -- & -- \\
\hline & $03-02-91$ & 0610 & 14 & 87 & 13 & 4.9 & -- & -- \\
\hline & 03-03-91 & 0845 & 17 & 81 & 10 & 4.3 & -- & -- \\
\hline & $03-04-91$ & 1030 & 25 & 79 & 11 & 4.0 & -- & -- \\
\hline & $03-05-91$ & 1210 & 12 & 81 & 4 & 4.4 & -- & -- \\
\hline & $11-23-91$ & 1150 & 0.3 & 125 & 2 & 9.1 & -- & - \\
\hline & $11-25-91$ & 1300 & 5.0 & 117 & 7 & 8.1 & -- & - \\
\hline & $01-10-92$ & 1120 & 1.9 & 108 & 4 & 9.2 & -- & -- \\
\hline & $01-23-92$ & 1045 & 12 & 95 & 16 & 7.1 & -- & -- \\
\hline & $01-23-92$ & 2025 & 12 & 99 & 9 & 6.7 & -- & - \\
\hline & $01-24-92$ & 1000 & 8.7 & 101 & 4 & 9.5 & -- & -- \\
\hline & $01-28-92$ & 0745 & 40 & 88 & 15 & -- & -- & -- \\
\hline & $01-28-92$ & 1130 & 36 & 93 & 12 & 4.9 & - & $\cdots$ \\
\hline & $01-29-92$ & 1115 & 25 & 93 & 7 & 2.5 & -- & -- \\
\hline & $01-30-92$ & 1940 & 27 & 88 & 1,020 & 9.4 & -- & -- \\
\hline & $01-31-92$ & 1100 & 31 & 92 & 6 & 6.5 & -- & -- \\
\hline & $02-04-92$ & 1015 & 7.4 & 99 & 3 & 7.2 & -- & -- \\
\hline & $02-20-92$ & 1240 & 12 & 90 & 6 & 6.0 & -- & -- \\
\hline & $02-21-92$ & 0630 & 12 & 89 & 7 & 5.8 & -- & -- \\
\hline & $02-21-92$ & 1125 & 20 & 85 & 15 & 5.2 & -- & -- \\
\hline & $02-24-92$ & 0925 & 5.3 & 93 & 3 & 4.9 & -- & -- \\
\hline & $03-24-92$ & 1435 & -- & 101 & -- & 6.2 & -- & -- \\
\hline & $04-21-92$ & 1245 & -- & 94 & -- & 4.4 & -- & -- \\
\hline \multirow[t]{10}{*}{380} & $01-31-91$ & 1345 & 0.5 & 338 & 62 & -- & 3.0 & 1.3 \\
\hline & $02-02-91$ & 2100 & 4.0 & 86 & 83 & 4.6 & 4.9 & $<0.1$ \\
\hline & $02-03-91$ & 0815 & 2.1 & 107 & 13 & 5.2 & 7.4 & 0.1 \\
\hline & $02-04-91$ & 1215 & 1.6 & 124 & 5 & 5.6 & 8.8 & $<0.1$ \\
\hline & $02-06-91$ & 1115 & 0.8 & 132 & 41 & 6.6 & 1.7 & $<0.1$ \\
\hline & $03-01-91$ & 1250 & 0.2 & 174 & 7 & 4.4 & -- & - \\
\hline & $03-02-91$ & 1040 & 0.7 & 114 & 7 & 4.1 & -- & -- \\
\hline & $03-02-91$ & 1610 & 2.0 & 101 & 28 & 4.7 & -- & -- \\
\hline & 03-03-91 & 0750 & 1.8 & 102 & -- & 5.0 & -- & -- \\
\hline & $03-03-91$ & 1440 & 2.9 & 96 & 31 & 4.3 & -- & -- \\
\hline
\end{tabular}


Table A1.--Discharge, specific conductance, suspended-sediment, chloride, sulfate, and fluoride data for the Clover Creek Basin, 1991-92--Continued

\begin{tabular}{|c|c|c|c|c|c|c|c|c|}
\hline $\begin{array}{l}\text { Site } \\
\text { num- } \\
\text { ber }^{1}\end{array}$ & Date & Time & $\begin{array}{l}\text { Dis- } \\
\text { charge, } \\
\left(\mathrm{ft}^{3} / \mathrm{s}\right)\end{array}$ & $\begin{array}{l}\text { Spe- } \\
\text { cific } \\
\text { con- } \\
\text { duc- } \\
\text { tance } \\
(\mu S / c m)\end{array}$ & $\begin{array}{l}\text { Sedi- } \\
\text { ment, } \\
\text { sus- } \\
\text { pended } \\
(\mathrm{mg} / \mathrm{L})\end{array}$ & $\begin{array}{l}\text { Chlo- } \\
\text { ride, } \\
\text { dis- } \\
\text { solved } \\
(\mathrm{mg} / \mathrm{L} \\
\text { as } \mathrm{Cl})\end{array}$ & $\begin{array}{l}\text { Sulfate, } \\
\text { dis- } \\
\text { solved } \\
(\mathrm{mg} / \mathrm{L} \\
\left.\text { as } \mathrm{SO}_{4}\right)\end{array}$ & $\begin{array}{l}\text { Fluo- } \\
\text { ride, } \\
\text { dis- } \\
\text { solved } \\
(\mathrm{mg} / \mathrm{L} \\
\text { as } \mathrm{F})\end{array}$ \\
\hline \multirow[t]{13}{*}{380} & $03-04-91$ & 0900 & 2.0 & 106 & 6 & 4.6 & -- & -- \\
\hline & $01-10-92$ & 1240 & 0.3 & 162 & 23 & 14 & -- & -- \\
\hline & $01-23-92$ & 1230 & 0.8 & 132 & -- & 9.3 & -- & -- \\
\hline & 01-24-92 & 1100 & 0.7 & 146 & 6 & 16 & -- & -- \\
\hline & $01-28-92$ & 0900 & 2.4 & 119 & 10 & 6.1 & -- & -- \\
\hline & $01-29-92$ & 1030 & 2.3 & 123 & 9 & 10 & -- & -- \\
\hline & $01-31-92$ & 1015 & 2.4 & 128 & 6 & 6.2 & -- & -- \\
\hline & 02-04-92 & 0900 & 0.4 & 147 & 5 & 8.4 & -- & -- \\
\hline & $02-21-92$ & 0830 & 2.1 & 101 & 40 & 4.1 & -- & -- \\
\hline & $02-21-92$ & 1455 & 2.3 & 102 & 100 & 5.7 & -- & -- \\
\hline & $02-24-92$ & 0725 & 0.6 & 138 & 5 & 7.4 & -- & -- \\
\hline & $03-24-92$ & 1105 & 0.2 & 165 & -- & 9.4 & -- & -- \\
\hline & $04-21-92$ & 0800 & -- & 165 & -- & 8.0 & -- & -- \\
\hline \multirow[t]{25}{*}{395} & $01-12-91$ & 0930 & 82 & 89 & 154 & 6.7 & 6.5 & $<0.1$ \\
\hline & $01-14-91$ & 0935 & 20 & 115 & 3 & 6.7 & 8.1 & $<0.1$ \\
\hline & $01-23-91$ & 0940 & 3.0 & 145 & 2 & 7.7 & 11 & $<0.1$ \\
\hline & $02-01-91$ & 0900 & 6.5 & 127 & 6 & 7.7 & 9.4 & 0.1 \\
\hline & $02-02-91$ & 2300 & 63 & 93 & 157 & 6.2 & 6.1 & $<0.1$ \\
\hline & $02-03-91$ & 1050 & 43 & 97 & 16 & 6.1 & 7.6 & $<0.1$ \\
\hline & 02-04-91 & 1115 & 33 & 104 & 9 & 5.1 & 7.4 & $<0.1$ \\
\hline & 03-01-91 & 0930 & 2.2 & 143 & 2 & 6.0 & -- & -- \\
\hline & $03-02-91$ & 0815 & 12 & 109 & 8 & 5.7 & -- & -- \\
\hline & $03-02-91$ & 1455 & 18 & 104 & 17 & 5.3 & -- & -- \\
\hline & 03-03-91 & 0910 & 31 & 99 & 15 & 1.9 & -- & -- \\
\hline & $03-04-91$ & 1100 & 39 & 93 & 9 & 4.4 & -- & -- \\
\hline & $03-05-91$ & 1230 & 16 & 104 & 5 & 4.8 & -- & -- \\
\hline & $06-11-91$ & 1320 & 0.1 & 188 & -- & 7.6 & -- & -- \\
\hline & $06-26-91$ & 1420 & 0.0 & 185 & -- & 8.4 & -- & -- \\
\hline & $11-23-91$ & 1330 & 1.8 & 207 & 5 & 13 & -- & -- \\
\hline & $11-25-91$ & 1110 & 12 & 125 & 63 & 7.4 & -- & -- \\
\hline & $01-10-92$ & 1040 & 5.0 & 162 & 28 & 11 & -- & -- \\
\hline & $01-23-92$ & 0930 & 20 & 113 & 117 & 6.5 & -- & - \\
\hline & $01-23-92$ & 2000 & 20 & 128 & 53 & 7.4 & -- & -- \\
\hline & $01-24-92$ & 0930 & 11 & 128 & 22 & -- & -- & -- \\
\hline & $01-28-92$ & 0715 & 48 & 108 & 157 & 5.8 & -- & -- \\
\hline & $01-28-92$ & 1200 & 39 & 116 & 74 & 5.8 & -- & -- \\
\hline & $01-29-92$ & 1145 & 38 & 116 & 49 & 5.9 & -- & -- \\
\hline & $01-30-92$ & 2005 & 44 & 112 & 61 & 5.2 & -- & -- \\
\hline
\end{tabular}


Table A1.--Discharge, specific conductance, suspended-sediment, chloride, sulfate, and fuoride data for the Clover Creek Basin, 1991-92--Continued

\begin{tabular}{|c|c|c|c|c|c|c|c|c|}
\hline $\begin{array}{l}\text { Site } \\
\text { num- } \\
\text { ber }^{1}\end{array}$ & Date & Time & $\begin{array}{l}\text { Dis- } \\
\text { charge, } \\
\left(\mathrm{ft}^{3} / \mathrm{s}\right)\end{array}$ & $\begin{array}{l}\text { Spe- } \\
\text { cific } \\
\text { con- } \\
\text { duc- } \\
\text { tance } \\
(\mu \mathrm{S} / \mathrm{cm})\end{array}$ & $\begin{array}{l}\text { Sedi- } \\
\text { ment, } \\
\text { sus- } \\
\text { pended } \\
(\mathrm{mg} / \mathrm{L})\end{array}$ & $\begin{array}{l}\text { Chlo- } \\
\text { ride, } \\
\text { dis- } \\
\text { solved } \\
(\mathrm{mg} / \mathrm{L} \\
\text { as } \mathrm{Cl})\end{array}$ & $\begin{array}{l}\text { Sulfate, } \\
\text { dis- } \\
\text { solved } \\
(\mathrm{mg} / \mathrm{L} \\
\left.\text { as } \mathrm{SO}_{4}\right)\end{array}$ & $\begin{array}{l}\text { Fluo- } \\
\text { ride, } \\
\text { dis- } \\
\text { solved } \\
\text { (mg/L } \\
\text { as F) }\end{array}$ \\
\hline \multirow[t]{8}{*}{395} & $01-31-92$ & 1130 & 42 & 125 & 57 & 5.7 & -- & -- \\
\hline & $02-04-92$ & 1030 & 8.1 & 139 & 7 & 9.5 & -- & -- \\
\hline & $02-20-92$ & 1315 & 15 & 116 & 12 & 4.4 & -- & -- \\
\hline & $02-21-92$ & 0550 & 19 & 120 & 32 & 4.5 & -- & -- \\
\hline & $02-21-92$ & 1050 & 31 & 107 & 48 & 6.0 & -- & -- \\
\hline & $02-24-92$ & 1000 & 11 & 124 & 7 & 5.4 & -- & -- \\
\hline & $03-24-92$ & 1350 & 1.5 & 160 & -- & 7.8 & -- & -- \\
\hline & $04-21-92$ & 1315 & -- & 141 & -- & 5.7 & - & - \\
\hline \multirow{15}{*}{400} & $01-12-91$ & 0845 & 112 & 87 & 151 & 5.4 & 5.4 & $<0.1$ \\
\hline & $01-12-91$ & 1400 & 118 & 85 & 68 & 5.3 & 6.3 & $<0.1$ \\
\hline & $01-14-91$ & 1005 & 27 & 108 & 4 & 6.4 & 7.7 & $<0.1$ \\
\hline & $01-23-91$ & 1010 & 2.6 & 120 & 2 & 7.1 & 8.5 & $<0.1$ \\
\hline & $02-02-91$ & 2330 & 101 & 83 & 214 & 5.3 & 4.8 & $<0.1$ \\
\hline & $02-03-91$ & 1525 & 68 & 92 & 22 & 5.7 & 6.8 & $<0.1$ \\
\hline & $02-04-91$ & 0820 & 52 & 95 & 13 & 5.0 & 6.3 & $<0.1$ \\
\hline & $02-06-91$ & 1215 & 18 & 105 & 5 & 5.8 & 7.9 & $<0.1$ \\
\hline & 03-01-91 & 1115 & 7.9 & 126 & 1 & 7.1 & -- & -. \\
\hline & $03-02-91$ & 0735 & 30 & 100 & 10 & 4.0 & -- & -- \\
\hline & $03-02-91$ & 1425 & 36 & 96 & 14 & 4.9 & -- & -- \\
\hline & 03-03-91 & 0930 & 52 & 93 & 16 & 4.8 & -- & -- \\
\hline & 03-04-91 & 1300 & 64 & 88 & 12 & 4.5 & -- & -- \\
\hline & $03-05-91$ & 1245 & 33 & 96 & 5 & 4.5 & -- & -- \\
\hline & $11-23-91$ & 1400 & 0.7 & 207 & 15 & 12 & -- & -- \\
\hline \multirow[t]{15}{*}{400} & $11-24-91$ & 0845 & 3.8 & 137 & 24 & 5.0 & -- & -- \\
\hline & $01-10-92$ & 0945 & 4.6 & 151 & 17 & 6.0 & -- & -- \\
\hline & $01-22-92$ & 2000 & 2.0 & 144 & -- & -- & -- & -- \\
\hline & $01-23-92$ & 0830 & 40 & 106 & 115 & 6.8 & -- & -- \\
\hline & $01-23-92$ & 1920 & 31 & 118 & 28 & -- & -- & -- \\
\hline & $01-24-92$ & 0900 & 26 & 116 & 13 & 7.0 & -- & -- \\
\hline & $01-28-92$ & 0535 & 76 & 97 & 111 & 9.0 & -- & -- \\
\hline & $01-28-92$ & 1300 & 65 & 106 & 43 & 5.9 & -- & -- \\
\hline & $01-29-92$ & 1215 & -- & 108 & 28 & 7.2 & -- & -- \\
\hline & $01-30-92$ & 2030 & 64 & 102 & 41 & 5.3 & -- & -- \\
\hline & $01-31-92$ & 1200 & 62 & 107 & 25 & 5.3 & -- & -- \\
\hline & $02-04-92$ & 1100 & 14 & 124 & 7 & 7.5 & -- & -- \\
\hline & $02-19-92$ & 1115 & 17 & 111 & 5 & 5.8 & -- & -- \\
\hline & $02-21-92$ & 0520 & 26 & 110 & 17 & 9.9 & -- & -- \\
\hline & $02-21-92$ & 1300 & 46 & 99 & 22 & 5.5 & -- & -- \\
\hline
\end{tabular}


Table A1.--Discharge, specific conductance, suspended-sediment, chloride, sulfate, and fluoride data for the Clover Creek Basin, 1991-92--Continued

\begin{tabular}{|c|c|c|c|c|c|c|c|c|}
\hline $\begin{array}{l}\text { Site } \\
\text { num- } \\
\text { ber }^{1}\end{array}$ & Date & Time & $\begin{array}{l}\text { Dis- } \\
\text { charge, } \\
\left(\mathrm{ft}^{3} / \mathrm{s}\right)\end{array}$ & $\begin{array}{l}\text { Spe- } \\
\text { cific } \\
\text { con- } \\
\text { duc- } \\
\text { tance } \\
(\mu \mathrm{S} / \mathrm{cm})\end{array}$ & $\begin{array}{l}\text { Sedi- } \\
\text { ment, } \\
\text { sus- } \\
\text { pended } \\
(\mathrm{mg} / \mathrm{L})\end{array}$ & $\begin{array}{l}\text { Chlo- } \\
\text { ride, } \\
\text { dis- } \\
\text { solved } \\
\text { (mg/L } \\
\text { as } \mathrm{Cl})\end{array}$ & $\begin{array}{l}\text { Sulfate, } \\
\text { dis- } \\
\text { solved } \\
(\mathrm{mg} / \mathrm{L} \\
\left.{\left.\text { as } \mathrm{SO}_{4}\right)}\right)\end{array}$ & $\begin{array}{l}\text { Fluo- } \\
\text { ride, } \\
\text { dis- } \\
\text { solved } \\
(\mathrm{mg} / \mathrm{L} \\
\text { as F) }\end{array}$ \\
\hline \multirow[t]{3}{*}{400} & $02-24-92$ & 1045 & 18 & 113 & 6 & 6.3 & -- & -- \\
\hline & $03-24-92$ & 1320 & 0.6 & 152 & -- & 6.8 & -- & -- \\
\hline & $04-21-92$ & 1340 & -- & 124 & -- & 5.1 & -- & -- \\
\hline \multirow[t]{27}{*}{430} & $01-11-91$ & 1230 & 24 & 120 & 12 & 7.2 & 7.5 & $<0.1$ \\
\hline & $01-12-91$ & 0910 & 78 & 87 & 50 & 5.2 & 5.3 & $<0.1$ \\
\hline & $01-12-91$ & 1400 & 90 & 85 & 24 & 5.7 & 5.9 & $<0.1$ \\
\hline & $01-14-91$ & 1050 & 36 & 120 & 3 & 7.0 & 6.3 & $<0.1$ \\
\hline & $01-23-91$ & 1415 & 12 & 139 & 1 & 7.8 & 7.0 & $<0.1$ \\
\hline & $02-01-91$ & 0930 & 7.7 & 126 & 3 & 7.1 & 6.4 & $<0.1$ \\
\hline & 02-03-91 & 0005 & 59 & 91 & 107 & 5.3 & 6.5 & $<0.1$ \\
\hline & 02-03-91 & 1410 & 56 & 90 & 14 & 5.5 & 5.7 & $<0.1$ \\
\hline & 02-04-91 & 1230 & 49 & 100 & 6 & 5.3 & 6.8 & $<0.1$ \\
\hline & $02-06-91$ & 1015 & 29 & 121 & 3 & 6.4 & 11 & $<0.1$ \\
\hline & $03-01-91$ & 0900 & 15 & 140 & 1 & 7.3 & -- & -- \\
\hline & $03-02-91$ & 0915 & 29 & 114 & 8 & 5.3 & -- & -- \\
\hline & 03-03-91 & 1600 & 64 & 97 & 11 & 4.9 & -- & -- \\
\hline & 03-04-91 & 1210 & 74 & 100 & 4 & 5.0 & -- & -- \\
\hline & 03-05-91 & 1310 & 52 & 115 & 3 & 6.2 & -- & -- \\
\hline & $11-24-91$ & 1015 & 4.1 & 33 & 14 & 9.8 & -- & -- \\
\hline & $11-25-91$ & 1010 & 16 & 111 & 31 & 6.3 & -- & -- \\
\hline & $01-10-92$ & 1045 & 3.0 & 104 & 35 & 5.7 & -- & -- \\
\hline & 01-23-92 & 1215 & 23 & 107 & 64 & 11 & -- & -- \\
\hline & $01-23-92$ & 2025 & 24 & 101 & 42 & 6.1 & -- & - \\
\hline & $01-25-92$ & 0930 & 11 & 125 & 7 & 11 & -- & -- \\
\hline & $01-28-92$ & 1100 & 51 & 101 & 29 & 11 & -- & -- \\
\hline & $01-31-92$ & 1400 & 40 & 107 & 15 & 4.3 & -- & -- \\
\hline & 02-04-92 & 1225 & 9.6 & 119 & 10 & 7.3 & -- & -- \\
\hline & $02-21-92$ & 1000 & 35 & 101 & 44 & 5.9 & -- & -- \\
\hline & $02-24-92$ & 1120 & 17 & 117 & 7 & 5.5 & -- & -- \\
\hline & $04-21-92$ & 1110 & 5.3 & 120 & -- & 5.3 & -- & -- \\
\hline 448 & $06-26-91$ & 0834 & 5.4 & 98 & -- & 3.4 & -- & -- \\
\hline \multirow[t]{7}{*}{452} & $01-11-91$ & 1320 & 26 & 123 & 3 & 5.3 & 4.9 & $<0.1$ \\
\hline & $01-23-91$ & 1300 & 28 & 125 & 3 & 6.0 & 5.7 & $<0.1$ \\
\hline & 02-03-91 & 1435 & 33 & 121 & 3 & 6.3 & 6.0 & $<0.1$ \\
\hline & 02-04-91 & 1130 & 34 & 121 & 5 & 5.6 & 5.9 & $<0.1$ \\
\hline & $02-06-91$ & 1320 & 32 & 121 & 2 & 6.1 & 6.3 & $<0.1$ \\
\hline & $03-01-91$ & 1300 & 37 & 117 & 2 & 5.9 & -- & - \\
\hline & $03-02-91$ & 1410 & 40 & 117 & 2 & 4.4 & -- & -- \\
\hline
\end{tabular}


Table A1.--Discharge, specific conductance, suspended-sediment, chloride, sulfate, and fuoride data for the Clover Creek Basin, 1991-92--Continued

\begin{tabular}{|c|c|c|c|c|c|c|c|c|}
\hline $\begin{array}{l}\text { Site } \\
\text { num- } \\
\text { ber }^{1}\end{array}$ & Date & Time & $\begin{array}{l}\text { Dis- } \\
\text { charge, } \\
\left(\mathrm{ft}^{3} / \mathrm{s}\right)\end{array}$ & $\begin{array}{l}\text { Spe- } \\
\text { cific } \\
\text { con- } \\
\text { duc- } \\
\text { tance } \\
(\mu \mathrm{S} / \mathrm{cm})\end{array}$ & $\begin{array}{l}\text { Sedi- } \\
\text { ment, } \\
\text { sus- } \\
\text { pended } \\
(\mathrm{mg} / \mathrm{L})\end{array}$ & $\begin{array}{l}\text { Chlo- } \\
\text { ride, } \\
\text { dis- } \\
\text { solved } \\
(\mathrm{mg} / \mathrm{L} \\
\text { as } \mathrm{Cl})\end{array}$ & $\begin{array}{l}\text { Sulfate, } \\
\text { dis- } \\
\text { solved } \\
(\mathrm{mg} / \mathrm{L} \\
\left.\text { as } \mathrm{SO}_{4}\right)\end{array}$ & $\begin{array}{l}\text { Fluo- } \\
\text { ride, } \\
\text { dis- } \\
\text { solved } \\
\text { (mg/L } \\
\text { as F) }\end{array}$ \\
\hline \multirow[t]{21}{*}{452} & $03-04-91$ & 0950 & 45 & 116 & 1 & 6.0 & -- & -- \\
\hline & $03-13-91$ & 1400 & 42 & 116 & 2 & 5.2 & -- & -- \\
\hline & $06-11-91$ & 1235 & 22 & 107 & -- & 4.6 & -- & -- \\
\hline & $06-26-91$ & 0910 & 19 & 110 & -. & 5.8 & -. & -- \\
\hline & $08-27-91$ & 0810 & 8.0 & 113 & -- & 15 & - & -- \\
\hline & 09-04-91 & 0810 & 8.4 & 115 & -- & 6.2 & -- & -- \\
\hline & 09-04-91 & 1120 & 8.4 & 114 & -. & -- & -- & -- \\
\hline & 09-04-91 & 1430 & 8.4 & 114 & -- & 5.8 & -- & -- \\
\hline & $09-04-91$ & 1730 & 8.4 & 114 & -- & -- & -- & -- \\
\hline & 09-04-91 & 1945 & 8.4 & 114 & -. & 6.3 & -- & -- \\
\hline & 09-04-91 & 2255 & 8.4 & 114 & -- & -- & -- & -- \\
\hline & 09-05-91 & 0150 & 8.4 & 112 & -- & -- & -- & -- \\
\hline & $11-24-91$ & 1045 & 8.4 & 122 & 2 & 6.6 & -- & -- \\
\hline & $01-15-92$ & 0945 & 9.9 & 120 & 3 & 6.9 & -- & -- \\
\hline & $01-23-92$ & 1315 & 11 & 118 & 3 & 12 & -- & -- \\
\hline & $01-25-92$ & 1020 & 11 & 119 & 3 & 6.6 & -- & -. \\
\hline & $01-28-92$ & 1200 & 14 & 115 & 4 & 6.5 & -- & -- \\
\hline & $02-04-92$ & 1010 & 19 & 116 & 2 & 6.8 & -- & -- \\
\hline & $02-21-92$ & 1500 & 19 & 115 & 3 & 6.9 & -- & -- \\
\hline & $03-24-92$ & 0955 & 18 & 118 & -- & 6.2 & -- & -- \\
\hline & $04-21-92$ & 0935 & 18 & 115 & -- & 6.0 & -- & -- \\
\hline \multirow[t]{18}{*}{460} & $06-11-91$ & 1100 & 18 & 115 & -- & 5.3 & -- & -- \\
\hline & $06-26-91$ & 1055 & 5.2 & 117 & -- & 6.1 & -- & -- \\
\hline & $08-27-91$ & 1145 & 4.3 & 121 & -- & 6.2 & -- & -- \\
\hline & 09-04-91 & 1025 & 3.8 & 124 & -- & 6.4 & -- & -- \\
\hline & 09-04-91 & 1240 & 3.8 & 125 & -- & - & -- & -- \\
\hline & $09-04-91$ & 1645 & 3.8 & 124 & -- & 6.9 & -- & -- \\
\hline & 09-04-91 & 1910 & 3.8 & 124 & -- & -- & -- & -- \\
\hline & 09-04-91 & 2210 & 4.0 & 120 & -- & 6.4 & -- & -- \\
\hline & $09-05-91$ & 0110 & 4.0 & 119 & -- & -- & -- & -- \\
\hline & $09-05-91$ & 0420 & 4.0 & 118 & -- & -- & -- & -- \\
\hline & $11-23-91$ & 1400 & 8.1 & 128 & 4 & 8.1 & -- & -- \\
\hline & $11-25-91$ & 1005 & 11 & 118 & 2 & 6.4 & -- & -- \\
\hline & $01-15-92$ & 1130 & 9.2 & 128 & 3 & 7.4 & -- & -- \\
\hline & $01-23-92$ & 1245 & 14 & 124 & 2 & 7.5 & -- & -- \\
\hline & $01-25-92$ & 1110 & 13 & 125 & 2 & 6.1 & -- & -- \\
\hline & $01-28-92$ & 1355 & 16 & 113 & 3 & 6.4 & -- & -- \\
\hline & $01-31-92$ & 1430 & 21 & 120 & 3 & 8.3 & -- & -- \\
\hline & $02-04-92$ & 1140 & 21 & 122 & 4 & 7.3 & -- & -- \\
\hline
\end{tabular}


Table A1.--Discharge, specific conductance, suspended-sediment, chloride, sulfate, and fluoride data for the Clover Creek Basin, 1991-92--Continued

\begin{tabular}{|c|c|c|c|c|c|c|c|c|}
\hline $\begin{array}{l}\text { Site } \\
\text { num- } \\
\text { ber }^{1}\end{array}$ & Date & Time & $\begin{array}{l}\text { Dis- } \\
\text { charge, } \\
\left(\mathrm{ft}^{3} / \mathrm{s}\right)\end{array}$ & $\begin{array}{l}\text { Spe- } \\
\text { cific } \\
\text { con- } \\
\text { duc- } \\
\text { tance } \\
(\mu \mathrm{S} / \mathrm{cm})\end{array}$ & $\begin{array}{l}\text { Sedi- } \\
\text { ment, } \\
\text { sus- } \\
\text { pended } \\
(\mathrm{mg} / \mathrm{L})\end{array}$ & $\begin{array}{l}\text { Chlo- } \\
\text { ride, } \\
\text { dis- } \\
\text { solved } \\
(\mathrm{mg} / \mathrm{L} \\
\text { as } \mathrm{Cl})\end{array}$ & $\begin{array}{l}\text { Sulfate, } \\
\text { dis- } \\
\text { solved } \\
(\mathrm{mg} / \mathrm{L} \\
\left.\text { as } \mathrm{SO}_{4}\right)\end{array}$ & $\begin{array}{l}\text { Fluo- } \\
\text { ride, } \\
\text { dis- } \\
\text { solved } \\
\text { (mg/L } \\
\text { as F) }\end{array}$ \\
\hline \multirow[t]{4}{*}{460} & $02-21-92$ & 1115 & 22 & 120 & 4 & 7.9 & -- & -- \\
\hline & $02-27-92$ & 1040 & 19 & 126 & 3 & 4.9 & -- & -- \\
\hline & $03-24-92$ & 1135 & 14 & 128 & -- & 7.1 & -- & -- \\
\hline & $04-21-92$ & 1215 & 15 & 122 & -- & 6.5 & -- & -- \\
\hline \multirow[t]{27}{*}{480} & 03-01-91 & 1345 & 8.6 & 123 & 10 & 6.7 & -- & -- \\
\hline & 03-02-91 & 1315 & 8.6 & 120 & 8 & 5.8 & -- & -- \\
\hline & 03-03-91 & 1630 & 10 & 118 & 10 & 6.1 & -- & -- \\
\hline & 03-04-91 & 1035 & 10 & 121 & 6 & 6.0 & -- & -- \\
\hline & $06-11-91$ & 1135 & 5.9 & 115 & -- & 5.0 & -- & -- \\
\hline & $06-12-91$ & 1130 & -- & -- & -- & -- & -- & -- \\
\hline & $06-26-91$ & 1009 & 5.6 & 118 & -- & 6.1 & -- & -- \\
\hline & $08-27-91$ & 1110 & 4.3 & 121 & -- & 7.1 & -- & -- \\
\hline & 09-04-91 & 0950 & 4.8 & 130 & -- & 6.6 & -- & -- \\
\hline & 09-04-91 & 1220 & 4.8 & 130 & -- & -- & -- & -- \\
\hline & 09-04-91 & 1535 & 4.8 & 130 & -. & 6.8 & -- & -- \\
\hline & 09-04-91 & 1850 & 4.6 & 130 & -- & -. & -- & -- \\
\hline & 09-04-91 & 2205 & 4.6 & 131 & -- & 6.4 & -- & -- \\
\hline & $09-05-91$ & 0130 & 4.6 & 126 & -- & -- & -- & -- \\
\hline & $09-05-91$ & 0430 & 4.6 & 124 & -- & -- & -- & -- \\
\hline & $11-23-91$ & 1300 & 0.7 & 126 & 10 & 7.4 & -- & -- \\
\hline & $11-25-91$ & 0910 & 2.3 & 108 & 12 & 5.8 & -- & -- \\
\hline & $01-15-92$ & 1035 & 1.9 & 127 & 7 & 14 & -- & -- \\
\hline & $01-23-92$ & 1350 & 1.9 & 119 & 5 & 7.6 & -- & -- \\
\hline & $01-25-92$ & 1005 & 1.9 & 125 & 9 & 7.2 & -- & -- \\
\hline & $01-28-92$ & 1130 & 3.2 & 114 & 3 & 6.8 & -- & -- \\
\hline & $01-31-92$ & 1515 & 4.9 & 124 & 2 & 6.2 & -- & -- \\
\hline & $02-04-92$ & 1050 & 4.9 & 120 & 14 & 7.0 & -- & -- \\
\hline & $02-21-92$ & 1005 & 5.8 & 114 & 10 & 7.1 & -- & -- \\
\hline & $02-27-92$ & 1010 & 5.5 & 123 & 19 & 6.4 & -- & -- \\
\hline & $03-24-92$ & 1045 & 4.3 & 125 & -- & 6.8 & -- & -- \\
\hline & $04-21-92$ & 1015 & 5.5 & 120 & -- & 6.5 & -- & -- \\
\hline \multirow[t]{8}{*}{500} & 01-04-91 & 1430 & 43 & 137 & -- & 6.7 & 7.1 & $<0.1$ \\
\hline & $01-11-91$ & 1115 & 65 & 124 & 5 & 6.6 & 5.9 & $<0.1$ \\
\hline & $01-12-91$ & 1200 & 92 & 102 & 9 & 5.4 & 5.1 & $<0.1$ \\
\hline & $01-14-91$ & 1215 & 92 & 125 & -- & 7.0 & 6.4 & $<0.1$ \\
\hline & $01-23-91$ & 0900 & 68 & 134 & 3 & 7.0 & 7.2 & $<0.1$ \\
\hline & $02-01-91$ & 1415 & 53 & 132 & 2 & 6.3 & 6.1 & $<0.1$ \\
\hline & 02-03-91 & 1315 & 87 & 103 & 10 & 6.1 & 6.2 & $<0.1$ \\
\hline & $02-04-91$ & 1415 & 92 & 115 & 4 & 5.7 & 6.6 & $<0.1$ \\
\hline
\end{tabular}


Table A1.--Discharge, specific conductance, suspended-sediment, chloride, sulfate, and fluoride data for the Clover Creek Basin, 1991-92--Continued

\begin{tabular}{|c|c|c|c|c|c|c|c|c|}
\hline $\begin{array}{l}\text { Site } \\
\text { num- } \\
\text { ber }^{1}\end{array}$ & Date & Time & $\begin{array}{l}\text { Dis- } \\
\text { charge, } \\
\left(\mathrm{ft}^{3} / \mathrm{s}\right)\end{array}$ & $\begin{array}{l}\text { Spe- } \\
\text { cific } \\
\text { con- } \\
\text { duc- } \\
\text { tance } \\
(\mu \mathrm{S} / \mathrm{cm})\end{array}$ & $\begin{array}{l}\text { Sedi- } \\
\text { ment, } \\
\text { sus- } \\
\text { pended } \\
(\mathrm{mg} / \mathrm{L})\end{array}$ & $\begin{array}{l}\text { Chlo- } \\
\text { ride, } \\
\text { dis- } \\
\text { solved } \\
(\mathrm{mg} / \mathrm{L} \\
\text { as } \mathrm{Cl})\end{array}$ & $\begin{array}{l}\text { Sulfate, } \\
\text { dis- } \\
\text { solved } \\
(\mathrm{mg} / \mathrm{L} \\
\left.\text { as } \mathrm{SO}_{4}\right)\end{array}$ & $\begin{array}{l}\text { Fluo- } \\
\text { ride, } \\
\text { dis- } \\
\text { solved } \\
\text { (mg/L } \\
\text { as F) }\end{array}$ \\
\hline \multirow[t]{34}{*}{500} & $02-06-91$ & 0930 & 85 & 124 & 3 & 6.0 & 11 & $<0.1$ \\
\hline & $03-01-91$ & 1015 & 80 & 130 & 2 & 5.3 & -- & -- \\
\hline & 03-02-91 & 1030 & 88 & 120 & 3 & 6.3 & -- & -- \\
\hline & 03-03-91 & 1515 & 115 & 105 & 6 & 4.7 & -- & -- \\
\hline & 03-04-91 & 1300 & 120 & 111 & 5 & 5.9 & -- & -- \\
\hline & $03-13-91$ & 1505 & 109 & 123 & 3 & 6.2 & -- & -- \\
\hline & $06-11-91$ & 0920 & 35 & 120 & -- & 6.0 & -- & -- \\
\hline & $06-26-91$ & 1210 & 30 & 126 & -- & 6.3 & -- & -- \\
\hline & $08-20-91$ & 0940 & 9.6 & 132 & 2 & 6.8 & -- & -- \\
\hline & $08-27-91$ & 0945 & 9.9 & 103 & 5 & 5.7 & -- & -- \\
\hline & 09-04-91 & 0855 & 7.5 & 134 & -- & 6.7 & -- & -- \\
\hline & 09-04-91 & 1200 & 7.7 & 134 & -- & -- & -- & -- \\
\hline & 09-04-91 & 1450 & 7.7 & 133 & -- & 6.5 & -- & -- \\
\hline & 09-04-91 & 1830 & 7.5 & 134 & -- & -- & -- & -- \\
\hline & $09-04-91$ & 2105 & 7.5 & 135 & -- & 7.1 & -- & -- \\
\hline & $09-05-91$ & 0050 & 7.5 & 131 & -- & -- & -- & -. \\
\hline & $09-05-91$ & 0350 & 7.2 & 128 & -- & -- & -- & -- \\
\hline & $10-16-91$ & 1100 & 11 & 123 & 24 & 2.4 & -- & -- \\
\hline & $11-23-91$ & 1045 & 8.1 & 134 & 1 & 7.4 & -- & -- \\
\hline & $11-25-91$ & 0810 & 18 & 78 & 2 & 3.6 & -- & -- \\
\hline & $01-10-92$ & 0945 & 42 & 110 & 9 & 10 & -- & -- \\
\hline & $01-15-92$ & 0830 & 16 & 138 & 2 & 6.6 & -- & -- \\
\hline & $01-23-92$ & 1030 & 26 & 112 & 5 & 5.9 & -- & -- \\
\hline & $01-23-92$ & 1930 & 39 & 108 & 17 & 6.4 & -- & -- \\
\hline & $01-25-92$ & 0930 & 27 & 127 & 4 & 7.1 & -- & -- \\
\hline & $01-28-92$ & 0915 & 50 & 98 & 20 & 4.0 & -- & -- \\
\hline & $01-29-92$ & 1345 & 56 & 115 & 10 & 6.2 & -- & -- \\
\hline & $01-31-92$ & 1600 & 80 & 113 & 12 & 5.8 & -- & -- \\
\hline & $02-04-92$ & 0915 & 70 & 127 & 4 & 7.6 & -- & -- \\
\hline & $02-19-92$ & 0945 & 65 & 124 & 4 & 6.4 & -- & -- \\
\hline & $02-21-92$ & 0845 & 84 & 96 & 9 & 3.8 & -- & -- \\
\hline & $02-27-92$ & 1125 & 50 & 134 & 3 & 6.7 & -- & -- \\
\hline & $03-24-92$ & 0855 & 32 & 135 & -- & 7.1 & -- & -. \\
\hline & $04-21-92$ & 0830 & 45 & 127 & -- & 6.4 & -- & -. \\
\hline \multirow[t]{5}{*}{602} & $01-11-91$ & 0930 & 64 & 123 & 6 & 7.0 & 6.4 & $<0.1$ \\
\hline & $01-23-91$ & 1045 & 76 & 134 & 13 & 6.9 & 6.8 & $<0.1$ \\
\hline & $02-03-91$ & 1245 & 104 & 92 & 16 & 4.8 & 4.9 & $<0.1$ \\
\hline & 02-04-91 & 1520 & 117 & 115 & 6 & 5.7 & 6.6 & $<0.1$ \\
\hline & $02-06-91$ & 0850 & 104 & 125 & 5 & 6.4 & 11 & $<0.1$ \\
\hline
\end{tabular}


Table A1.--Discharge, specific conductance, suspended-sediment, chloride, sulfate, and fluoride data for the Clover Creek Basin, 1991-92--Continued

\begin{tabular}{|c|c|c|c|c|c|c|c|c|}
\hline $\begin{array}{l}\text { Site } \\
\text { num- } \\
\text { ber }^{1}\end{array}$ & Date & Time & $\begin{array}{l}\text { Dis- } \\
\text { charge, } \\
\left(\mathrm{ft}^{3} / \mathrm{s}\right)\end{array}$ & $\begin{array}{l}\text { Spe- } \\
\text { cific } \\
\text { con- } \\
\text { duc- } \\
\text { tance } \\
(\mu \mathrm{S} / \mathrm{cm})\end{array}$ & $\begin{array}{l}\text { Sedi- } \\
\text { ment, } \\
\text { sus- } \\
\text { pended } \\
(\mathrm{mg} / \mathrm{L})\end{array}$ & $\begin{array}{l}\text { Chlo- } \\
\text { ride, } \\
\text { dis- } \\
\text { solved } \\
(\mathrm{mg} / \mathrm{L} \\
\text { as } \mathrm{Cl})\end{array}$ & $\begin{array}{l}\text { Sulfate, } \\
\text { dis- } \\
\text { solved } \\
(\mathrm{mg} / \mathrm{L} \\
\left.{\left.\text { as } \mathrm{SO}_{4}\right)}\right)\end{array}$ & $\begin{array}{l}\text { Fluo- } \\
\text { ride, } \\
\text { dis- } \\
\text { solved } \\
\text { (mg/L } \\
\text { as F) }\end{array}$ \\
\hline \multirow[t]{20}{*}{602} & 03-01-91 & 1115 & 97 & 130 & 1 & 7.5 & -- & -- \\
\hline & $03-02-91$ & 1115 & 106 & 119 & 4 & 5.8 & -- & -- \\
\hline & 03-03-91 & 1415 & 141 & 110 & 5 & 6.0 & -- & -- \\
\hline & $06-26-91$ & 1303 & 29 & 125 & -- & 6.4 & -- & -- \\
\hline & $08-27-91$ & 0830 & 13 & 133 & -- & 8.4 & -- & -- \\
\hline & 09-04-91 & 0805 & 7.8 & 135 & -- & 7.1 & -- & -- \\
\hline & 09-04-91 & 1130 & 7.8 & 133 & -- & -- & -- & -- \\
\hline & 09-04-91 & 1355 & 7.8 & 132 & -- & 6.4 & -- & -- \\
\hline & $09-04-91$ & 1800 & 7.8 & 133 & -- & -- & -- & -- \\
\hline & $09-04-91$ & 2010 & 7.8 & 134 & - & 7.0 & -- & -- \\
\hline & 09-05-91 & 0020 & 7.8 & 130 & -- & -- & -- & -- \\
\hline & 09-05-91 & 0330 & 7.8 & 128 & -- & -- & -- & -- \\
\hline & $11-24-91$ & 0915 & 13 & 112 & 2 & 4.3 & -- & -- \\
\hline & $01-25-92$ & 0910 & 23 & 125 & 4 & 7.2 & -- & -- \\
\hline & $01-28-92$ & 1000 & 46 & 91 & 18 & 10 & -- & -- \\
\hline & 02-04-92 & 0820 & 50 & 125 & 5 & 7.8 & -- & -- \\
\hline & $02-21-92$ & 1605 & 67 & 113 & 8 & 6.5 & -- & -- \\
\hline & $03-24-92$ & 0755 & 35 & 135 & -- & 7.1 & -- & -- \\
\hline & $04-21-92$ & 0725 & 40 & 126 & -- & 6.5 & -. & -- \\
\hline & \multicolumn{8}{|c|}{ Precipitation sites } \\
\hline \multirow[t]{3}{*}{1} & $11-23-91$ & 0800 & -- & 9 & -- & 0.4 & -- & -- \\
\hline & $01-22-92$ & 1845 & -- & 13 & -- & 0.5 & -- & -- \\
\hline & $02-20-92$ & 1200 & -- & 12 & -- & 1.5 & -- & -- \\
\hline 2 & $11-23-91$ & 0800 & -- & 8 & -- & 0.5 & -- & -- \\
\hline
\end{tabular}

${ }^{1}$ Site numbers, except for 1 and 2 for the two precipitation sites, are the last digits of the eight-digit stream-flow stations assigned by the U.S. Geological Survey (for example, site 330 refers to station number 12090330). 
Table A2.--Nitrogen and phosphorus data for the Clover Creek Basin, 1991-92

[mg/L, milligrams per liter; <, less than; --, no data available]

\begin{tabular}{|c|c|c|c|c|c|c|c|c|}
\hline $\begin{array}{l}\text { Site } \\
\text { num- } \\
\text { ber }^{1}\end{array}$ & Date & Time & $\begin{array}{l}\text { Nitrogen, } \\
\text { nitrite plus } \\
\text { nitrate, } \\
\text { dis- } \\
\text { solved } \\
\text { (mg/L } \\
\text { as } \mathrm{N} \text { ) }\end{array}$ & $\begin{array}{l}\text { Nitrogen, } \\
\text { ammonia, } \\
\text { dis- } \\
\text { solved } \\
\text { (mg/L } \\
\text { as } \mathrm{N} \text { ) }\end{array}$ & $\begin{array}{l}\text { Nitrogen, } \\
\text { ammonia } \\
\text { plus } \\
\text { organic, } \\
\text { total } \\
\text { (mg/L } \\
\text { as } \mathrm{N})\end{array}$ & $\begin{array}{l}\text { Nitrogen, } \\
\text { nitrite, } \\
\text { dis- } \\
\text { solved } \\
\text { (mg/L } \\
\text { as } \mathrm{N} \text { ) }\end{array}$ & $\begin{array}{l}\text { Phos- } \\
\text { phorus, } \\
\text { ortho- } \\
\text { phosphate, } \\
\text { dissolved } \\
\text { (mg/L } \\
\text { as P) }\end{array}$ & $\begin{array}{l}\text { Phos- } \\
\text { phorus, } \\
\text { total } \\
(\mathrm{mg} / \mathrm{L} \\
\text { as } \mathrm{P})\end{array}$ \\
\hline \multirow[t]{2}{*}{325} & $03-24-92$ & 1250 & 2.50 & 0.02 & $<0.2$ & $<0.01$ & $<0.01$ & $<0.01$ \\
\hline & $04-21-92$ & 1045 & 1.90 & 0.01 & $<0.2$ & $<0.01$ & 0.01 & $<0.01$ \\
\hline \multirow[t]{18}{*}{330} & $01-23-91$ & 0845 & 1.90 & 0.01 & $<0.2$ & $<0.01$ & $<0.01$ & 0.01 \\
\hline & $03-02-91$ & 1120 & 1.60 & 0.01 & $<0.2$ & $<0.01$ & $<0.01$ & 0.02 \\
\hline & $06-11-91$ & 1445 & 2.00 & 0.01 & 0.4 & 0.02 & $<0.01$ & 0.02 \\
\hline & $08-27-91$ & 1020 & 2.00 & 0.02 & 0.2 & 0.01 & $<0.01$ & 0.03 \\
\hline & 09-04-91 & 0940 & 2.10 & $<0.01$ & 0.2 & $<0.01$ & 0.01 & 0.02 \\
\hline & 09-04-91 & 1555 & 2.20 & 0.02 & 0.2 & 0.01 & 0.01 & 0.02 \\
\hline & 09-04-91 & 2040 & 2.20 & 0.03 & $<0.2$ & 0.01 & 0.01 & 0.02 \\
\hline & $11-23-91$ & 1630 & 2.20 & 0.01 & $<0.2$ & $<0.01$ & 0.02 & 0.03 \\
\hline & $01-10-92$ & 1230 & 2.20 & 0.02 & $<0.2$ & $<0.01$ & 0.02 & 0.03 \\
\hline & $01-23-92$ & 1500 & 2.10 & 0.02 & $<0.2$ & $<0.01$ & 0.02 & 0.03 \\
\hline & $01-25-92$ & 1100 & 2.10 & 0.02 & $<0.2$ & $<0.01$ & 0.02 & 0.02 \\
\hline & $01-28-92$ & 1310 & 1.80 & 0.01 & 0.3 & $<0.01$ & 0.02 & 0.02 \\
\hline & $02-04-92$ & 1230 & 1.70 & $<0.01$ & $<0.2$ & $<0.01$ & 0.01 & $<0.01$ \\
\hline & $02-19-92$ & 1320 & 2.00 & $<0.01$ & $<0.2$ & $<0.01$ & 0.02 & 0.02 \\
\hline & $02-21-92$ & 1400 & 1.90 & 0.03 & $<0.2$ & $<0.01$ & 0.02 & 0.02 \\
\hline & $02-27-92$ & 0915 & 1.90 & $<0.01$ & $<0.2$ & $<0.01$ & 0.01 & 0.01 \\
\hline & $03-24-92$ & 1350 & 0.56 & 0.02 & 0.6 & $<0.01$ & $<0.01$ & 0.02 \\
\hline & $04-21-92$ & 1130 & 2.10 & 0.02 & $<0.2$ & $<0.01$ & 0.01 & $<0.01$ \\
\hline \multirow[t]{17}{*}{340} & $01-31-91$ & 1215 & 1.40 & 0.22 & 1.2 & 0.03 & 0.09 & 0.22 \\
\hline & $02-02-91$ & 2140 & 1.80 & 0.62 & 1.3 & 0.03 & 0.16 & 0.27 \\
\hline & $02-03-91$ & 1030 & 2.20 & 0.43 & 0.9 & 0.02 & 0.12 & 0.18 \\
\hline & $03-02-91$ & 0500 & 1.50 & 0.49 & 1.4 & 0.01 & 0.16 & 0.23 \\
\hline & $03-02-91$ & 0845 & 1.40 & 0.64 & 1.4 & 0.01 & 0.10 & 0.14 \\
\hline & $03-02-91$ & 0855 & 1.20 & 0.41 & 2.2 & $<0.01$ & 0.10 & 0.26 \\
\hline & $03-02-91$ & 1540 & 1.20 & 0.55 & 1.2 & $<0.01$ & 0.15 & 0.19 \\
\hline & 03-03-91 & 0650 & 1.50 & 0.41 & 0.9 & $<0.01$ & 0.10 & 0.15 \\
\hline & $01-23-92$ & 1430 & 3.20 & 0.59 & 1.1 & 0.05 & 0.14 & 0.18 \\
\hline & $01-28-92$ & 1030 & 4.00 & 0.61 & 1.1 & 0.05 & 0.13 & 0.16 \\
\hline & $01-29-92$ & 0945 & 3.50 & 0.54 & 1.0 & 0.05 & 0.13 & 0.15 \\
\hline & $01-30-92$ & 0815 & 2.30 & 0.41 & 1.0 & 0.04 & 0.12 & 0.21 \\
\hline & $01-31-92$ & 0945 & 3.50 & 0.46 & 1.1 & 0.05 & 0.12 & 0.16 \\
\hline & 02-21-92 & 0645 & 1.80 & 0.36 & 1.8 & 0.04 & 0.10 & 0.45 \\
\hline & $02-21-92$ & 1410 & 3.20 & 0.36 & 1.0 & 0.06 & 0.14 & 0.19 \\
\hline & $02-24-92$ & 0815 & 2.60 & 0.62 & 1.2 & 0.06 & 0.15 & 0.22 \\
\hline & $03-24-92$ & 0825 & 1.50 & 0.42 & 1.0 & 0.03 & 0.16 & 0.25 \\
\hline
\end{tabular}


Table A2.--Nitrogen and phosphorus data for the Clover Creek Basin, 1991-92--Continued

\begin{tabular}{|c|c|c|c|c|c|c|c|c|}
\hline $\begin{array}{l}\text { Site } \\
\text { num- } \\
\text { ber }^{1}\end{array}$ & Date & Time & $\begin{array}{l}\text { Nitrogen, } \\
\text { nitrite plus } \\
\text { nitrate, } \\
\text { dis- } \\
\text { solved } \\
\text { (mg/L } \\
\text { as } \mathrm{N} \text { ) }\end{array}$ & $\begin{array}{l}\text { Nitrogen, } \\
\text { ammonia } \\
\text { dis- } \\
\text { solved } \\
(\mathrm{mg} / \mathrm{L} \\
\text { as } \mathrm{N})\end{array}$ & $\begin{array}{l}\text { Nitrogen, } \\
\text { ammonia } \\
\text { plus } \\
\text { organic, } \\
\text { total } \\
\text { (mg/L } \\
\text { as } \mathrm{N} \text { ) }\end{array}$ & $\begin{array}{l}\text { Nitrogen, } \\
\text { nitrite, } \\
\text { dis- } \\
\text { solved } \\
\text { (mg/L } \\
\text { as } \mathrm{N} \text { ) }\end{array}$ & $\begin{array}{l}\text { Phos- } \\
\text { phorus, } \\
\text { ortho- } \\
\text { phosphate, } \\
\text { dissolved } \\
\text { (mg/L } \\
\text { as } \mathrm{P} \text { ) }\end{array}$ & $\begin{array}{l}\text { Phos- } \\
\text { phorus, } \\
\text { total } \\
(\mathrm{mg} / \mathrm{L} \\
\text { as } \mathrm{P})\end{array}$ \\
\hline \multirow[t]{24}{*}{355} & $01-12-91$ & 1030 & 2.00 & 0.04 & 0.7 & $<0.01$ & 0.01 & 0.01 \\
\hline & $01-14-91$ & 0815 & 2.40 & 0.04 & 0.5 & $<0.01$ & 0.01 & 0.02 \\
\hline & $01-23-91$ & 0745 & 2.90 & 0.02 & 0.3 & $<0.01$ & $<0.01$ & $<0.01$ \\
\hline & $02-03-91$ & 0930 & 2.00 & 0.02 & 0.3 & 0.02 & 0.01 & 0.03 \\
\hline & $02-04-91$ & 0940 & 2.10 & 0.01 & 0.4 & $<0.01$ & 0.01 & 0.02 \\
\hline & $02-06-91$ & 1145 & 2.50 & 0.01 & 0.4 & 0.01 & 0.02 & 0.02 \\
\hline & $03-01-91$ & 0820 & 2.50 & 0.02 & 0.3 & $<0.01$ & $<0.01$ & 0.01 \\
\hline & $03-02-91$ & 1140 & 2.20 & 0.01 & 0.2 & $<0.01$ & $<0.01$ & 0.02 \\
\hline & $03-03-91$ & 0830 & 2.00 & $<0.01$ & 0.3 & $<0.01$ & $<0.01$ & 0.01 \\
\hline & $03-04-91$ & 0900 & 1.90 & $<0.01$ & 0.2 & $<0.01$ & $<0.01$ & 0.01 \\
\hline & $03-13-91$ & 1315 & 2.30 & $<0.01$ & 0.3 & $<0.01$ & $<0.01$ & 0.03 \\
\hline & $06-11-91$ & 1345 & 1.80 & 0.02 & 0.5 & 0.03 & $<0.01$ & $<0.01$ \\
\hline & $08-27-91$ & 0915 & 2.30 & 0.02 & 0.3 & 0.01 & $<0.01$ & 0.01 \\
\hline & $09-04-91$ & 0850 & 2.40 & 0.03 & 0.3 & 0.02 & $<0.01$ & 0.01 \\
\hline & 09-04-91 & 1515 & 2.40 & 0.03 & 0.6 & 0.01 & $<0.01$ & 0.02 \\
\hline & 09-04-91 & 2015 & 2.40 & 0.04 & 0.3 & 0.02 & $<0.01$ & 0.01 \\
\hline & $11-23-91$ & 1515 & 3.30 & 0.03 & $<0.2$ & 0.01 & $<0.01$ & $<0.01$ \\
\hline & $01-23-92$ & 1530 & 2.70 & 0.02 & 0.2 & $<0.01$ & 0.01 & 0.05 \\
\hline & $01-25-92$ & 1200 & 3.00 & 0.02 & $<0.2$ & $<0.01$ & $<0.01$ & 0.02 \\
\hline & $01-28-92$ & 1335 & 1.90 & 0.03 & 0.6 & 0.01 & 0.02 & 0.05 \\
\hline & $02-04-92$ & 1315 & 2.60 & 0.02 & $<0.2$ & $<0.01$ & 0.01 & $<0.01$ \\
\hline & $02-21-92$ & 1300 & 2.40 & $<0.01$ & 0.3 & $<0.01$ & 0.01 & 0.02 \\
\hline & $03-24-92$ & 1440 & 2.70 & 0.02 & 1.0 & $<0.01$ & $<0.01$ & $<0.01$ \\
\hline & $04-21-92$ & 1210 & 2.40 & 0.03 & $<0.2$ & $<0.01$ & $<0.01$ & $<0.01$ \\
\hline \multirow[t]{13}{*}{360} & $01-12-91$ & 1200 & 2.10 & 0.03 & 0.4 & $<0.01$ & 0.03 & 0.02 \\
\hline & $01-23-91$ & 1040 & 2.90 & $<0.01$ & 0.4 & $<0.01$ & $<0.01$ & $<0.01$ \\
\hline & $02-03-91$ & 1510 & 1.80 & 0.02 & 0.4 & $<0.01$ & 0.02 & 0.03 \\
\hline & $02-04-91$ & 0930 & 2.00 & $<0.01$ & 0.5 & $<0.01$ & $<0.01$ & 0.03 \\
\hline & $02-06-91$ & 1240 & 2.30 & 0.01 & 0.4 & 0.01 & 0.01 & 0.01 \\
\hline & $03-01-91$ & 1145 & 2.30 & 0.02 & 0.4 & $<0.01$ & $<0.01$ & 0.02 \\
\hline & $03-02-91$ & 1210 & 2.20 & $<0.01$ & 0.3 & $<0.01$ & 0.02 & 0.03 \\
\hline & $03-04-91$ & 1145 & 1.90 & $<0.01$ & $<0.2$ & $<0.01$ & $<0.01$ & 0.01 \\
\hline & $06-11-91$ & 1535 & 1.60 & 0.01 & 0.4 & 0.03 & $<0.01$ & 0.02 \\
\hline & $01-25-92$ & 1245 & 2.70 & $<0.01$ & $<0.2$ & $<0.01$ & $<0.01$ & 0.02 \\
\hline & $02-04-92$ & 1315 & 2.50 & $<0.01$ & 0.3 & $<0.01$ & $<0.01$ & 0.02 \\
\hline & $03-24-92$ & 1250 & 1.80 & 0.01 & $<0.2$ & $<0.01$ & 0.02 & 0.01 \\
\hline & $04-21-92$ & 1255 & 2.10 & 0.03 & $<0.2$ & $<0.01$ & $<0.01$ & $<0.01$ \\
\hline \multirow[t]{2}{*}{365} & $01-31-91$ & 1245 & 0.20 & 0.05 & 0.7 & 0.02 & 0.01 & 0.05 \\
\hline & $02-02-91$ & 2210 & 0.40 & 0.01 & 0.5 & $<0.01$ & 0.01 & 0.03 \\
\hline
\end{tabular}


Table A2.--Nitrogen and phosphorus data for the Clover Creek Basin, 1991-92--Continued

\begin{tabular}{|c|c|c|c|c|c|c|c|c|}
\hline $\begin{array}{l}\text { Site } \\
\text { num- } \\
\text { ber }^{1}\end{array}$ & Date & Time & $\begin{array}{l}\text { Nitrogen, } \\
\text { nitrite plus } \\
\text { nitrate, } \\
\text { dis- } \\
\text { solved } \\
(\mathrm{mg} / \mathrm{L} \\
\text { as } \mathrm{N})\end{array}$ & $\begin{array}{l}\text { Nitrogen, } \\
\text { ammonia } \\
\text { dis- } \\
\text { solved } \\
(\mathrm{mg} / \mathrm{L} \\
\text { as } \mathrm{N})\end{array}$ & $\begin{array}{l}\text { Nitrogen, } \\
\text { ammonia } \\
\text { plus } \\
\text { organic, } \\
\text { total } \\
(\mathrm{mg} / \mathrm{L} \\
\text { as } \mathrm{N})\end{array}$ & $\begin{array}{l}\text { Nitrogen, } \\
\text { nitrite, } \\
\text { dis- } \\
\text { solved } \\
\text { (mg/L } \\
\text { as } \mathrm{N} \text { ) }\end{array}$ & $\begin{array}{l}\text { Phos- } \\
\text { phorus, } \\
\text { ortho- } \\
\text { phosphate, } \\
\text { dissolved } \\
\text { (mg/L } \\
\text { as P) }\end{array}$ & $\begin{array}{l}\text { Phos- } \\
\text { phorus, } \\
\text { total } \\
\text { (mg/L } \\
\text { as } \mathrm{P} \text { ) }\end{array}$ \\
\hline \multirow[t]{23}{*}{365} & $02-03-91$ & 0850 & 0.20 & 0.04 & 0.8 & $<0.01$ & 0.03 & 0.07 \\
\hline & $02-04-91$ & 1140 & 0.40 & 0.03 & 0.5 & $<0.01$ & 0.01 & 0.02 \\
\hline & $03-01-91$ & 1215 & 0.16 & 0.05 & 1.0 & $<0.01$ & $<0.01$ & 0.05 \\
\hline & $03-02-91$ & 0540 & 0.13 & 0.04 & 1.0 & $<0.01$ & $<0.01$ & 0.05 \\
\hline & $03-02-91$ & 1520 & 0.11 & 0.05 & 0.9 & $<0.01$ & 0.02 & 0.06 \\
\hline & $03-03-91$ & 0815 & 0.19 & 0.03 & 0.9 & $<0.01$ & 0.01 & 0.05 \\
\hline & $03-04-91$ & 0945 & 0.22 & 0.02 & 0.4 & $<0.01$ & $<0.01$ & 0.02 \\
\hline & $03-05-91$ & 1145 & 0.26 & 0.03 & 1.1 & $<0.01$ & $<0.01$ & 0.02 \\
\hline & $01-10-92$ & 1320 & 0.24 & 0.05 & 1.1 & $<0.01$ & 0.01 & 0.07 \\
\hline & $01-22-92$ & 2035 & 0.13 & 0.03 & 0.8 & $<0.01$ & $<0.01$ & 0.06 \\
\hline & $01-23-92$ & 1130 & 0.21 & 0.05 & 0.9 & $<0.01$ & 0.02 & 0.11 \\
\hline & 01-24-92 & 1030 & 0.29 & 0.03 & 0.6 & $<0.01$ & 0.01 & 0.06 \\
\hline & $01-28-92$ & 0945 & 0.71 & 0.12 & 1.1 & 0.02 & 0.03 & 0.10 \\
\hline & $01-28-92$ & 1800 & 0.60 & 0.07 & 1.0 & $<0.01$ & 0.05 & 0.10 \\
\hline & $01-29-92$ & 0900 & 0.83 & 0.10 & 0.9 & 0.02 & 0.02 & 0.05 \\
\hline & $01-31-92$ & 0900 & 0.76 & 0.04 & 0.8 & $<0.01$ & 0.03 & 0.05 \\
\hline & $02-04-92$ & 0945 & 0.69 & 0.03 & 0.9 & $<0.01$ & $<0.01$ & 0.06 \\
\hline & $02-19-92$ & 1225 & 0.18 & 0.03 & 0.9 & $<0.01$ & $<0.01$ & 0.05 \\
\hline & $02-21-92$ & 0730 & 0.23 & 0.04 & 1.2 & $<0.01$ & 0.02 & 0.10 \\
\hline & $02-21-92$ & 1340 & 0.21 & 0.05 & 0.7 & $<0.01$ & $<0.01$ & 0.04 \\
\hline & $02-24-92$ & 0850 & 0.25 & 0.03 & 0.8 & $<0.01$ & $<0.01$ & 0.05 \\
\hline & $03-24-92$ & 0930 & 0.08 & 0.15 & 2.9 & 0.01 & 0.02 & 0.25 \\
\hline & $04-21-92$ & 0845 & 0.06 & 0.04 & 0.7 & $<0.01$ & $<0.01$ & 0.03 \\
\hline \multirow[t]{15}{*}{370} & $01-12-91$ & 1015 & 1.10 & 0.08 & 0.7 & $<0.01$ & 0.02 & 0.03 \\
\hline & $01-14-91$ & 0910 & 1.00 & 0.15 & 1.1 & $<0.01$ & 0.04 & 0.16 \\
\hline & $01-23-91$ & 0910 & 0.60 & 0.05 & 0.9 & $<0.01$ & $<0.01$ & 0.03 \\
\hline & $02-01-91$ & 0830 & 0.80 & 0.09 & 0.7 & $<0.01$ & 0.02 & 0.04 \\
\hline & $02-02-91$ & 2240 & 0.70 & 0.12 & 1.1 & $<0.01$ & 0.04 & 0.17 \\
\hline & 02-03-91 & 0950 & 0.90 & 0.06 & 0.6 & $<0.01$ & 0.03 & 0.08 \\
\hline & 02-04-91 & 1000 & 0.90 & 0.09 & 0.5 & $<0.01$ & 0.03 & 0.08 \\
\hline & 03-01-91 & 0900 & 0.58 & 0.04 & 0.7 & $<0.01$ & $<0.01$ & 0.03 \\
\hline & $03-02-91$ & 0610 & 0.54 & 0.10 & 0.9 & $<0.01$ & 0.01 & 0.07 \\
\hline & $03-03-91$ & 0845 & 0.58 & 0.06 & 0.7 & $<0.01$ & 0.02 & 0.05 \\
\hline & $03-04-91$ & 1030 & 0.59 & 0.06 & 0.4 & $<0.01$ & 0.02 & 0.05 \\
\hline & $03-05-91$ & 1210 & 0.63 & 0.05 & 0.8 & $<0.01$ & $<0.01$ & 0.04 \\
\hline & $11-23-91$ & 1150 & 3.10 & 0.02 & 0.3 & 0.01 & 0.02 & 0.03 \\
\hline & $11-25-91$ & 1300 & 3.20 & 0.06 & 0.7 & 0.02 & 0.03 & 0.11 \\
\hline & $01-23-92$ & 1045 & 1.10 & 0.09 & 0.7 & $<0.01$ & 0.03 & 0.09 \\
\hline
\end{tabular}


Table A2.--Nitrogen and phosphorus data for the Clover Creek Basin, 1991-92--Continued

\begin{tabular}{|c|c|c|c|c|c|c|c|c|}
\hline $\begin{array}{l}\text { Site } \\
\text { num- } \\
\text { ber }^{1}\end{array}$ & Date & Time & $\begin{array}{l}\text { Nitrogen, } \\
\text { nitrite plus } \\
\text { nitrate, } \\
\text { dis- } \\
\text { solved } \\
(\mathrm{mg} / \mathrm{L} \\
\text { as } \mathrm{N})\end{array}$ & $\begin{array}{l}\text { Nitrogen, } \\
\text { ammonia } \\
\text { dis- } \\
\text { solved } \\
(\mathrm{mg} / \mathrm{L} \\
\text { as } \mathrm{N})\end{array}$ & $\begin{array}{l}\text { Nitrogen, } \\
\text { ammonia } \\
\text { plus } \\
\text { organic, } \\
\text { total } \\
(\mathrm{mg} / \mathrm{L} \\
\text { as } \mathrm{N})\end{array}$ & $\begin{array}{l}\text { Nitrogen, } \\
\text { nitrite, } \\
\text { dis- } \\
\text { solved } \\
(\mathrm{mg} / \mathrm{L} \\
\text { as } \mathrm{N})\end{array}$ & $\begin{array}{l}\text { Phos- } \\
\text { phorus, } \\
\text { ortho- } \\
\text { phosphate, } \\
\text { dissolved } \\
\text { (mg/L } \\
\text { as P) }\end{array}$ & $\begin{array}{l}\text { Phos- } \\
\text { phorus, } \\
\text { total } \\
\text { (mg/L } \\
\text { as } \mathrm{P})\end{array}$ \\
\hline \multirow[t]{14}{*}{370} & 01-23-92 & 2025 & 1.10 & 0.06 & 0.7 & $<0.01$ & 0.02 & 0.08 \\
\hline & $01-24-92$ & 1000 & 1.30 & 0.06 & 0.7 & $<0.01$ & 0.02 & 0.06 \\
\hline & $01-28-92$ & 0745 & 1.20 & 0.07 & 1.1 & $<0.01$ & 0.04 & 0.11 \\
\hline & $01-28-92$ & 1130 & 1.40 & 0.08 & 0.8 & 0.03 & 0.04 & 0.08 \\
\hline & $01-29-92$ & 1115 & 1.50 & 0.09 & 0.8 & 0.02 & 0.03 & 0.07 \\
\hline & $01-30-92$ & 1940 & 1.30 & 0.06 & 0.8 & 0.01 & 0.03 & 0.07 \\
\hline & $01-31-92$ & 1100 & 1.50 & 0.08 & 0.8 & 0.02 & 0.04 & 0.07 \\
\hline & $02-04-92$ & 1015 & 1.20 & 0.02 & 0.6 & $<0.01$ & 0.02 & 0.03 \\
\hline & $02-20-92$ & 1240 & 0.77 & 0.03 & 0.7 & $<0.01$ & 0.02 & 0.06 \\
\hline & $02-21-92$ & 0630 & 0.77 & 0.03 & 1.1 & $<0.01$ & 0.02 & 0.06 \\
\hline & $02-21-92$ & 1125 & 0.77 & 0.05 & 0.8 & $<0.01$ & 0.02 & 0.09 \\
\hline & $02-24-92$ & 0925 & 0.79 & 0.02 & 0.6 & $<0.01$ & 0.02 & 0.05 \\
\hline & $03-24-92$ & 1435 & 0.35 & 0.02 & 0.5 & $<0.01$ & 0.01 & 0.03 \\
\hline & $04-21-92$ & 1245 & 0.30 & 0.04 & 0.7 & $<0.01$ & 0.01 & 0.01 \\
\hline \multirow[t]{23}{*}{380} & $01-31-91$ & 1345 & 0.60 & 0.61 & 2.3 & 0.02 & 0.07 & 0.43 \\
\hline & 02-02-91 & 2100 & 0.56 & 0.23 & 1.3 & 0.01 & 0.07 & 0.24 \\
\hline & 02-03-91 & 0815 & 0.80 & 0.16 & 0.7 & 0.01 & 0.05 & 0.09 \\
\hline & 02-04-91 & 1215 & 0.90 & 0.12 & 0.7 & $<0.01$ & 0.04 & 0.06 \\
\hline & 02-06-91 & 1115 & 0.70 & 0.16 & 0.8 & 0.01 & 0.05 & 0.09 \\
\hline & 03-01-91 & 1250 & 0.61 & 0.18 & 0.9 & 0.01 & 0.04 & 0.13 \\
\hline & 03-02-91 & 1040 & 0.45 & 0.17 & 0.7 & $<0.01$ & 0.06 & 0.11 \\
\hline & 03-02-91 & 1610 & 0.41 & 0.15 & 1.0 & $<0.01$ & 0.06 & 0.12 \\
\hline & 03-03-91 & 0750 & 0.45 & 0.11 & 0.8 & $<0.01$ & 0.05 & 0.10 \\
\hline & $03-03-91$ & 1440 & 0.41 & 0.12 & 0.9 & $<0.01$ & 0.04 & 0.14 \\
\hline & $03-04-91$ & 0900 & 0.50 & 0.15 & 0.3 & $<0.01$ & 0.06 & 0.10 \\
\hline & $01-10-92$ & 1240 & 0.77 & 0.34 & 1.5 & 0.02 & 0.05 & 0.24 \\
\hline & $01-23-92$ & 1230 & 1.00 & 0.21 & 1.0 & 0.01 & 0.09 & 0.21 \\
\hline & 01-24-92 & 1100 & 1.40 & 0.12 & 0.8 & 0.01 & 0.07 & 0.13 \\
\hline & $01-28-92$ & 0900 & 1.30 & 0.14 & 0.8 & 0.03 & 0.07 & 0.12 \\
\hline & $01-29-92$ & 1030 & 1.30 & 0.16 & 0.8 & 0.03 & 0.07 & 0.10 \\
\hline & $01-31-92$ & 1015 & 1.20 & 0.11 & 0.8 & 0.03 & 0.07 & 0.12 \\
\hline & 02-04-92 & 0900 & 1.10 & 0.08 & 0.6 & 0.01 & 0.06 & 0.09 \\
\hline & $02-21-92$ & 0830 & 0.58 & 0.09 & 0.8 & $<0.01$ & 0.05 & 0.15 \\
\hline & $02-21-92$ & 1455 & 0.60 & 0.15 & 1.2 & 0.01 & 0.06 & 0.26 \\
\hline & $02-24-92$ & 0725 & 0.75 & 0.19 & 0.9 & 0.02 & 0.07 & 0.14 \\
\hline & $03-24-92$ & 1105 & 0.44 & 0.09 & 0.7 & 0.02 & 0.08 & 0.15 \\
\hline & $04-21-92$ & 0800 & 0.53 & 0.18 & 0.8 & 0.02 & 0.07 & 0.14 \\
\hline \multirow[t]{2}{*}{395} & $01-12-91$ & 0930 & 1.00 & 0.14 & 0.7 & $<0.01$ & 0.04 & 0.09 \\
\hline & $01-14-91$ & 0935 & 1.30 & 0.07 & 0.8 & $<0.01$ & 0.02 & 0.03 \\
\hline
\end{tabular}


Table A2.--Nitrogen and phosphorus data for the Clover Creek Basin, 1991-92--Continued

\begin{tabular}{|c|c|c|c|c|c|c|c|c|}
\hline $\begin{array}{l}\text { Site } \\
\text { num- } \\
\text { ber }^{1}\end{array}$ & Date & Time & $\begin{array}{l}\text { Nitrogen, } \\
\text { nitrite plus } \\
\text { nitrate, } \\
\text { dis- } \\
\text { solved } \\
\text { (mg/L } \\
\text { as } \mathrm{N} \text { ) }\end{array}$ & $\begin{array}{l}\text { Nitrogen, } \\
\text { ammonia } \\
\text { dis- } \\
\text { solved } \\
(\mathrm{mg} / \mathrm{L} \\
\text { as } \mathrm{N})\end{array}$ & $\begin{array}{l}\text { Nitrogen, } \\
\text { ammonia } \\
\text { plus } \\
\text { organic, } \\
\text { total } \\
\text { (mg/L } \\
\text { as } \mathrm{N})\end{array}$ & $\begin{array}{l}\text { Nitrogen, } \\
\text { nitrite, } \\
\text { dis- } \\
\text { solved } \\
(\mathrm{mg} / \mathrm{L} \\
\text { as } \mathrm{N})\end{array}$ & $\begin{array}{l}\text { Phos- } \\
\text { phorus, } \\
\text { ortho- } \\
\text { phosphate, } \\
\text { dissolved } \\
\text { (mg/L } \\
\text { as } \mathrm{P})\end{array}$ & $\begin{array}{l}\text { Phos- } \\
\text { phorus, } \\
\text { total } \\
\text { (mg/L } \\
\text { as } \mathrm{P} \text { ) }\end{array}$ \\
\hline \multirow[t]{30}{*}{395} & $01-23-91$ & 0940 & 1.20 & 0.04 & 0.3 & $<0.01$ & 0.02 & 0.02 \\
\hline & $02-01-91$ & 0900 & 0.80 & 0.06 & 0.7 & $<0.01$ & 0.02 & 0.04 \\
\hline & $02-02-91$ & 2300 & 0.60 & 0.22 & 0.9 & $<0.01$ & 0.04 & 0.21 \\
\hline & $02-03-91$ & 1050 & 0.90 & 0.11 & 0.8 & 0.01 & 0.03 & 0.06 \\
\hline & $02-04-91$ & 1115 & 0.90 & 0.07 & 0.7 & $<0.01$ & 0.02 & 0.04 \\
\hline & $03-01-91$ & 0930 & 0.93 & 0.04 & 0.6 & $<0.01$ & $<0.01$ & 0.04 \\
\hline & $03-02-91$ & 0815 & 0.54 & 0.08 & 0.8 & $<0.01$ & 0.01 & 0.06 \\
\hline & $03-02-91$ & 1455 & 0.49 & 0.08 & 0.8 & $<0.01$ & 0.02 & 0.06 \\
\hline & 03-03-91 & 0910 & 0.60 & 0.08 & 0.8 & $<0.01$ & 0.03 & 0.06 \\
\hline & $03-04-91$ & 1100 & 0.65 & 0.07 & 0.6 & $<0.01$ & 0.02 & 0.05 \\
\hline & $03-05-91$ & 1230 & 0.86 & 0.04 & 0.9 & $<0.01$ & $<0.01$ & 0.05 \\
\hline & $06-11-91$ & 1320 & 0.69 & 0.02 & 0.6 & 0.02 & 0.01 & 0.04 \\
\hline & $11-23-91$ & 1330 & 1.50 & 0.12 & 0.7 & 0.04 & 0.02 & 0.08 \\
\hline & $11-25-91$ & 1110 & 1.70 & 0.10 & 0.8 & 0.03 & 0.03 & 0.20 \\
\hline & $01-10-92$ & 1040 & 1.30 & 0.10 & 0.9 & 0.01 & 0.02 & 0.18 \\
\hline & $01-23-92$ & 0930 & 0.89 & 0.12 & 0.9 & $<0.01$ & 0.02 & 0.20 \\
\hline & $01-23-92$ & 2000 & 1.20 & 0.14 & 1.1 & $<0.01$ & 0.03 & 0.14 \\
\hline & $01-24-92$ & 0930 & 1.40 & 0.09 & 0.7 & $<0.01$ & 0.03 & 0.08 \\
\hline & $01-28-92$ & 0715 & 1.40 & 0.12 & 1.2 & 0.02 & 0.04 & 0.20 \\
\hline & $01-28-92$ & 1200 & 1.60 & 0.11 & 0.9 & 0.03 & 0.04 & 0.08 \\
\hline & 01-29-92 & 1145 & 1.60 & 0.14 & 0.9 & 0.03 & 0.03 & 0.08 \\
\hline & $01-30-92$ & 2005 & 1.20 & 0.06 & 0.9 & 0.01 & 0.03 & 0.07 \\
\hline & $01-31-92$ & 1130 & 1.40 & 0.06 & 0.7 & $<0.01$ & 0.03 & 0.07 \\
\hline & $02-04-92$ & 1030 & 1.70 & 0.07 & 0.7 & $<0.01$ & 0.02 & 0.04 \\
\hline & $02-20-92$ & 1315 & 0.87 & 0.10 & 1.0 & 0.01 & 0.02 & 0.08 \\
\hline & $02-21-92$ & 0550 & 0.95 & 0.11 & 1.0 & 0.01 & 0.02 & 0.11 \\
\hline & $02-21-92$ & 1050 & 0.76 & 0.12 & 1.1 & 0.01 & 0.03 & 0.36 \\
\hline & $02-24-92$ & 1000 & 1.00 & 0.06 & 0.8 & 0.01 & 0.02 & 0.07 \\
\hline & $03-24-92$ & 1350 & 2.00 & 0.02 & $<0.2$ & $<0.01$ & 0.01 & $<0.01$ \\
\hline & $04-21-92$ & 1315 & 0.59 & 0.06 & 0.6 & 0.01 & 0.02 & 0.02 \\
\hline \multirow[t]{10}{*}{400} & $01-12-91$ & 0845 & 1.00 & 0.15 & 0.6 & $<0.01$ & 0.03 & 0.09 \\
\hline & $01-12-91$ & 1400 & 1.10 & 0.12 & 0.5 & $<0.01$ & 0.04 & 0.10 \\
\hline & $01-14-91$ & 1005 & 1.20 & 0.07 & 0.8 & 0.01 & 0.02 & 0.03 \\
\hline & $01-23-91$ & 1010 & 0.90 & 0.04 & 0.5 & 0.01 & 0.01 & 0.03 \\
\hline & $02-02-91$ & 2330 & 0.70 & 0.18 & 0.9 & 0.01 & 0.05 & 0.14 \\
\hline & $02-03-91$ & 1525 & 0.90 & 0.11 & 0.9 & 0.01 & 0.03 & 0.10 \\
\hline & $02-04-91$ & 0820 & 0.90 & 0.08 & 0.7 & $<0.01$ & 0.03 & 0.06 \\
\hline & 02-06-91 & 1215 & 1.00 & 0.04 & 0.7 & 0.01 & 0.02 & 0.03 \\
\hline & $03-01-91$ & 1115 & 0.78 & 0.03 & 0.7 & $<0.01$ & $<0.01$ & 0.03 \\
\hline & $03-02-91$ & 0735 & 0.57 & 0.09 & 0.9 & $<0.01$ & 0.02 & 0.06 \\
\hline
\end{tabular}


Table A2.--Nitrogen and phosphorus data for the Clover Creek Basin, 1991-92--Continued

\begin{tabular}{|c|c|c|c|c|c|c|c|c|}
\hline $\begin{array}{l}\text { Site } \\
\text { num- } \\
\text { ber }^{1}\end{array}$ & Date & Time & $\begin{array}{l}\text { Nitrogen, } \\
\text { nitrite plus } \\
\text { nitrate, } \\
\text { dis- } \\
\text { solved } \\
\text { (mg/L } \\
\text { as } \mathrm{N} \text { ) }\end{array}$ & $\begin{array}{l}\text { Nitrogen, } \\
\text { ammonia } \\
\text { dis- } \\
\text { solved } \\
\text { (mg/L } \\
\text { as } \mathrm{N})\end{array}$ & $\begin{array}{l}\text { Nitrogen, } \\
\text { ammonia } \\
\text { plus } \\
\text { organic, } \\
\text { total } \\
(\mathrm{mg} / \mathrm{L} \\
\text { as } \mathrm{N})\end{array}$ & $\begin{array}{l}\text { Nitrogen, } \\
\text { nitrite, } \\
\text { dis- } \\
\text { solved } \\
\text { (mg/L } \\
\text { as } \mathrm{N} \text { ) }\end{array}$ & $\begin{array}{l}\text { Phos- } \\
\text { phorus, } \\
\text { ortho- } \\
\text { phosphate, } \\
\text { dissolved } \\
\text { (mg/L } \\
\text { as } \mathrm{P} \text { ) }\end{array}$ & $\begin{array}{l}\text { Phos- } \\
\text { phorus, } \\
\text { total } \\
\text { (mg/L } \\
\text { as } \mathrm{P} \text { ) }\end{array}$ \\
\hline \multirow[t]{23}{*}{400} & $03-02-91$ & 1425 & 0.57 & 0.07 & 0.8 & $<0.01$ & 0.03 & 0.06 \\
\hline & $03-03-91$ & 0930 & 0.59 & 0.07 & 0.8 & $<0.01$ & 0.02 & 0.06 \\
\hline & $03-04-91$ & 1300 & 0.66 & 0.07 & 0.8 & $<0.01$ & 0.02 & 0.06 \\
\hline & $03-05-91$ & 1245 & 0.78 & 0.05 & 0.9 & $<0.01$ & $<0.01$ & 0.05 \\
\hline & $11-23-91$ & 1400 & 0.94 & 0.12 & 0.4 & 0.03 & $<0.01$ & 0.06 \\
\hline & $11-24-91$ & 0845 & 0.77 & 0.10 & 0.5 & 0.03 & 0.02 & 0.11 \\
\hline & $01-10-92$ & 0945 & 1.30 & 0.03 & $<0.2$ & 0.01 & 0.05 & 0.08 \\
\hline & $01-22-92$ & 2000 & 1.20 & 0.12 & 0.8 & $<0.01$ & 0.03 & 0.07 \\
\hline & $01-23-92$ & 0830 & 0.93 & 0.11 & 1.1 & $<0.01$ & 0.03 & 0.20 \\
\hline & $01-23-92$ & 1920 & 1.20 & 0.14 & 1.0 & 0.01 & 0.04 & 0.14 \\
\hline & $01-24-92$ & 0900 & 1.40 & 0.07 & 0.7 & $<0.01$ & 0.02 & 0.08 \\
\hline & $01-28-92$ & 0535 & 1.30 & 0.10 & 1.3 & 0.02 & 0.03 & 0.21 \\
\hline & $01-28-92$ & 1300 & 1.60 & 0.11 & 0.9 & 0.03 & 0.03 & 0.08 \\
\hline & $01-29-92$ & 1215 & 1.60 & 0.11 & 0.8 & 0.02 & 0.03 & 0.08 \\
\hline & $01-30-92$ & 2030 & 1.40 & 0.12 & 0.8 & 0.02 & 0.04 & 0.09 \\
\hline & $01-31-92$ & 1200 & 1.30 & 0.09 & 0.8 & 0.01 & 0.03 & 0.11 \\
\hline & $02-04-92$ & 1100 & 1.50 & 0.06 & 0.7 & $<0.01$ & 0.02 & 0.04 \\
\hline & $02-19-92$ & 1115 & 0.90 & 0.07 & 0.7 & $<0.01$ & 0.02 & 0.06 \\
\hline & $02-21-92$ & 0520 & 0.92 & 0.11 & 0.9 & 0.01 & 0.03 & 0.09 \\
\hline & $02-21-92$ & 1300 & 0.82 & 0.10 & 0.8 & 0.01 & 0.03 & 0.08 \\
\hline & $02-24-92$ & 1045 & 0.96 & 0.04 & 0.7 & $<0.01$ & 0.02 & 0.06 \\
\hline & $03-24-92$ & 1320 & 0.51 & 0.02 & 0.5 & $<0.01$ & $<0.01$ & 0.02 \\
\hline & $04-21-92$ & 1340 & 0.48 & 0.04 & 0.7 & $<0.01$ & 0.02 & 0.04 \\
\hline \multirow[t]{15}{*}{430} & $01-11-91$ & 1230 & 1.20 & 0.08 & 0.4 & $<0.01$ & 0.02 & 0.02 \\
\hline & $01-12-91$ & 0910 & 1.10 & 0.12 & 0.8 & 0.02 & 0.04 & 0.10 \\
\hline & $01-12-91$ & 1400 & 1.00 & 0.13 & 0.7 & $<0.01$ & 0.03 & 0.12 \\
\hline & $01-14-91$ & 1050 & 1.90 & 0.04 & 0.8 & $<0.01$ & 0.02 & 0.03 \\
\hline & $01-23-91$ & 1415 & 2.50 & $<0.01$ & 0.3 & $<0.01$ & 0.03 & 0.03 \\
\hline & $02-01-91$ & 0930 & 1.50 & 0.03 & 0.6 & $<0.01$ & 0.03 & 0.04 \\
\hline & $02-03-91$ & 0005 & 0.90 & 0.08 & 1.0 & 0.01 & 0.03 & 0.08 \\
\hline & $02-03-91$ & 1410 & 0.70 & 0.13 & 1.6 & 0.01 & 0.05 & 0.22 \\
\hline & $02-04-91$ & 1230 & 1.20 & 0.05 & 0.4 & $<0.01$ & 0.02 & 0.06 \\
\hline & $02-06-91$ & 1015 & 1.70 & 0.01 & 0.5 & 0.01 & 0.02 & 0.04 \\
\hline & $03-01-91$ & 0900 & 2.30 & 0.02 & 0.3 & $<0.01$ & 0.02 & 0.03 \\
\hline & $03-02-91$ & 0915 & 1.30 & 0.03 & 0.6 & $<0.01$ & $<0.01$ & 0.05 \\
\hline & 03-03-91 & 1600 & 0.87 & 0.04 & 0.3 & $<0.01$ & 0.03 & 0.05 \\
\hline & $03-04-91$ & 1210 & 0.99 & 0.03 & 0.6 & $<0.01$ & 0.03 & 0.04 \\
\hline & $03-05-91$ & 1310 & 1.50 & $<0.01$ & 0.7 & $<0.01$ & $<0.01$ & 0.03 \\
\hline
\end{tabular}


Table A2.--Nitrogen and phosphorus data for the Clover Creek Basin, 1991-92--Continued

\begin{tabular}{|c|c|c|c|c|c|c|c|c|}
\hline $\begin{array}{l}\text { Site } \\
\text { num- } \\
\text { ber }^{1}\end{array}$ & Date & Time & $\begin{array}{l}\text { Nitrogen, } \\
\text { nitrite plus } \\
\text { nitrate, } \\
\text { dis- } \\
\text { solved } \\
\text { (mg/L } \\
\text { as } \mathrm{N} \text { ) }\end{array}$ & $\begin{array}{l}\text { Nitrogen, } \\
\text { ammonia } \\
\text { dis- } \\
\text { solved } \\
(\mathrm{mg} / \mathrm{L} \\
\text { as } \mathrm{N})\end{array}$ & $\begin{array}{l}\text { Nitrogen, } \\
\text { ammonia } \\
\text { plus } \\
\text { organic, } \\
\text { total } \\
(\mathrm{mg} / \mathrm{L} \\
\text { as } \mathrm{N})\end{array}$ & $\begin{array}{l}\text { Nitrogen, } \\
\text { nitrite, } \\
\text { dis- } \\
\text { solved } \\
(\mathrm{mg} / \mathrm{L} \\
\text { as } \mathrm{N})\end{array}$ & $\begin{array}{l}\text { Phos- } \\
\text { phorus, } \\
\text { ortho- } \\
\text { phosphate, } \\
\text { dissolved } \\
\text { (mg/L } \\
\text { as P) }\end{array}$ & $\begin{array}{l}\text { Phos- } \\
\text { phorus, } \\
\text { total } \\
(\mathrm{mg} / \mathrm{L} \\
\text { as } \mathrm{P})\end{array}$ \\
\hline \multirow[t]{12}{*}{430} & $11-24-91$ & 1015 & 0.20 & 0.04 & $<0.2$ & 0.02 & 0.03 & 0.07 \\
\hline & $11-25-91$ & 1010 & 1.70 & 0.07 & 0.8 & 0.03 & 0.03 & 0.16 \\
\hline & $01-10-92$ & 1045 & 0.85 & 0.12 & 0.5 & 0.02 & 0.03 & 0.09 \\
\hline & $01-23-92$ & 1215 & 0.96 & 0.09 & 1.1 & $<0.01$ & 0.02 & 0.17 \\
\hline & $01-23-92$ & 2025 & 1.00 & 0.08 & 0.9 & $<0.01$ & 0.02 & 0.14 \\
\hline & $01-25-92$ & 0930 & 1.40 & 0.04 & 0.7 & $<0.01$ & $<0.01$ & 0.06 \\
\hline & $01-28-92$ & 1100 & 1.40 & 0.09 & 0.9 & 0.02 & 0.04 & 0.13 \\
\hline & $01-31-92$ & 1400 & 1.50 & 0.08 & 0.7 & 0.03 & 0.04 & 0.08 \\
\hline & $02-04-92$ & 1225 & 1.50 & 0.03 & 0.7 & 0.01 & 0.02 & 0.05 \\
\hline & $02-21-92$ & 1000 & 0.82 & 0.08 & 0.9 & 0.01 & 0.03 & 0.12 \\
\hline & $02-24-92$ & 1120 & 1.30 & 0.02 & 1.0 & 0.01 & 0.02 & 0.07 \\
\hline & $04-21-92$ & 1110 & 0.88 & 0.03 & 0.5 & $<0.01$ & 0.01 & 0.02 \\
\hline \multirow[t]{23}{*}{452} & $01-11-91$ & 1320 & 1.20 & 0.08 & 0.7 & $<0.01$ & 0.01 & $<0.01$ \\
\hline & $01-23-91$ & 1300 & 1.40 & 0.05 & 0.6 & $<0.01$ & $<0.01$ & 0.01 \\
\hline & $02-03-91$ & 1435 & 1.40 & 0.03 & 0.5 & $<0.01$ & $<0.01$ & 0.02 \\
\hline & $02-04-91$ & 1130 & 1.40 & 0.02 & 0.3 & $<0.01$ & $<0.01$ & 0.02 \\
\hline & $02-06-91$ & 1320 & 1.40 & 0.02 & 0.3 & 0.01 & 0.01 & 0.03 \\
\hline & $03-01-91$ & 1300 & 1.30 & 0.01 & 0.7 & $<0.01$ & $<0.01$ & 0.03 \\
\hline & $03-02-91$ & 1410 & 1.30 & $<0.01$ & 0.3 & $<0.01$ & $<0.01$ & 0.04 \\
\hline & $03-04-91$ & 0950 & 1.30 & $<0.01$ & 0.6 & $<0.01$ & $<0.01$ & 0.01 \\
\hline & $03-13-91$ & 1400 & 1.40 & $<0.01$ & 0.3 & $<0.01$ & $<0.01$ & 0.04 \\
\hline & $06-11-91$ & 1235 & 0.84 & 0.02 & 0.7 & 0.03 & $<0.01$ & $<0.01$ \\
\hline & $08-27-91$ & 0810 & $<0.05$ & 0.03 & 0.4 & 0.02 & $<0.01$ & 0.02 \\
\hline & 09-04-91 & 0810 & 0.11 & $<0.01$ & 0.4 & $<0.01$ & $<0.01$ & 0.02 \\
\hline & 09-04-91 & 1430 & 0.13 & 0.04 & 0.4 & 0.01 & $<0.01$ & 0.02 \\
\hline & $09-04-91$ & 1945 & 0.13 & 0.04 & 0.5 & 0.02 & $<0.01$ & 0.02 \\
\hline & $11-24-91$ & 1045 & 1.50 & 0.02 & $<0.2$ & 0.01 & $<0.01$ & 0.02 \\
\hline & $01-15-92$ & 0945 & 1.40 & 0.03 & 0.3 & 0.01 & 0.01 & 0.04 \\
\hline & $01-23-92$ & 1315 & 0.64 & 0.03 & 0.3 & $<0.01$ & $<0.01$ & 0.03 \\
\hline & $01-25-92$ & 1020 & 0.62 & 0.02 & 0.3 & $<0.01$ & $<0.01$ & 0.03 \\
\hline & $01-28-92$ & 1200 & 0.63 & 0.02 & 0.2 & $<0.01$ & $<0.01$ & 0.01 \\
\hline & $02-04-92$ & 1010 & 0.78 & 0.01 & 0.3 & $<0.01$ & $<0.01$ & 0.03 \\
\hline & $02-21-92$ & 1500 & 0.92 & 0.02 & 0.4 & $<0.01$ & $<0.01$ & 0.03 \\
\hline & $03-24-92$ & 0955 & 0.94 & 0.03 & $<0.2$ & 0.01 & $<0.01$ & $<0.01$ \\
\hline & $04-21-92$ & 0935 & 0.97 & 0.02 & $<0.2$ & $<0.01$ & $<0.01$ & $<0.01$ \\
\hline \multirow[t]{4}{*}{460} & $06-11-91$ & 1100 & 1.20 & 0.02 & 0.5 & 0.03 & $<0.01$ & 0.06 \\
\hline & $08-27-91$ & 1145 & 0.45 & 0.04 & 0.5 & 0.03 & $<0.01$ & 0.03 \\
\hline & $09-04-91$ & 1025 & 0.60 & 0.03 & 0.6 & 0.02 & $<0.01$ & 0.03 \\
\hline & $09-04-91$ & 1645 & 0.65 & 0.05 & 0.5 & 0.02 & $<0.01$ & 0.02 \\
\hline
\end{tabular}


Table A2.--Nitrogen and phosphorus data for the Clover Creek Basin, 1991-92--Continued

\begin{tabular}{|c|c|c|c|c|c|c|c|c|}
\hline $\begin{array}{l}\text { Site } \\
\text { num- } \\
\text { ber }^{1}\end{array}$ & Date & Time & $\begin{array}{l}\text { Nitrogen, } \\
\text { nitrite plus } \\
\text { nitrate, } \\
\text { dis- } \\
\text { solved } \\
\text { (mg/L } \\
\text { as } \mathrm{N})\end{array}$ & $\begin{array}{l}\text { Nitrogen, } \\
\text { ammonia } \\
\text { dis- } \\
\text { solved } \\
\text { (mg/L } \\
\text { as } \mathrm{N} \text { ) }\end{array}$ & $\begin{array}{l}\text { Nitrogen, } \\
\text { ammonia } \\
\text { plus } \\
\text { organic, } \\
\text { total } \\
\text { (mg/L } \\
\text { as } \mathrm{N} \text { ) }\end{array}$ & $\begin{array}{l}\text { Nitrogen, } \\
\text { nitrite, } \\
\text { dis- } \\
\text { solved } \\
\text { (mg/L } \\
\text { as } \mathrm{N} \text { ) }\end{array}$ & $\begin{array}{l}\text { Phos- } \\
\text { phorus, } \\
\text { ortho- } \\
\text { phosphate, } \\
\text { dissolved } \\
\text { (mg/L } \\
\text { as P) }\end{array}$ & $\begin{array}{l}\text { Phos- } \\
\text { phorus, } \\
\text { total } \\
\text { (mg/L } \\
\text { as } \mathrm{P} \text { ) }\end{array}$ \\
\hline \multirow[t]{13}{*}{460} & 09-04-91 & 2210 & 0.61 & 0.04 & 0.4 & 0.02 & $<0.01$ & 0.02 \\
\hline & $11-23-91$ & 1400 & 1.60 & 0.09 & 0.7 & 0.04 & 0.02 & 0.08 \\
\hline & $11-25-91$ & 1005 & 0.91 & 0.10 & 1.0 & 0.03 & $<0.01$ & 0.08 \\
\hline & $01-15-92$ & 1130 & 1.30 & 0.04 & 0.3 & 0.01 & 0.01 & 0.04 \\
\hline & $01-23-92$ & 1245 & 1.30 & 0.02 & $<0.2$ & $<0.01$ & $<0.01$ & 0.03 \\
\hline & $01-25-92$ & 1110 & 1.20 & 0.03 & 0.2 & $<0.01$ & 0.02 & 0.02 \\
\hline & $01-28-92$ & 1355 & 1.10 & 0.02 & 0.2 & $<0.01$ & 0.01 & 0.02 \\
\hline & $01-31-92$ & 1430 & 1.20 & 0.02 & $<0.2$ & $<0.01$ & $<0.01$ & 0.02 \\
\hline & $02-04-92$ & 1140 & 1.40 & 0.01 & 0.2 & $<0.01$ & $<0.01$ & 0.02 \\
\hline & $02-21-92$ & 1115 & 1.60 & 0.01 & 0.3 & $<0.01$ & $<0.01$ & 0.02 \\
\hline & $02-27-92$ & 1040 & 1.60 & $<0.01$ & 0.2 & $<0.01$ & $<0.01$ & 0.01 \\
\hline & $03-24-92$ & 1135 & 1.60 & 0.03 & 0.3 & 0.01 & $<0.01$ & 0.02 \\
\hline & $04-21-92$ & 1215 & 1.50 & 0.02 & 0.2 & 0.01 & $<0.01$ & $<0.01$ \\
\hline \multirow[t]{21}{*}{480} & $03-01-91$ & 1345 & 1.70 & 0.01 & 0.5 & $<0.01$ & $<0.01$ & 0.02 \\
\hline & $03-02-91$ & 1315 & 1.60 & 0.01 & 0.3 & $<0.01$ & $<0.01$ & 0.04 \\
\hline & $03-03-91$ & 1630 & 1.50 & 0.02 & $<0.2$ & $<0.01$ & $<0.01$ & 0.02 \\
\hline & $03-04-91$ & 1035 & 1.50 & 0.02 & 0.3 & $<0.01$ & $<0.01$ & 0.03 \\
\hline & $06-11-91$ & 1135 & 1.30 & 0.02 & 0.4 & 0.03 & $<0.01$ & 0.02 \\
\hline & $08-27-91$ & 1110 & 1.00 & 0.04 & 0.4 & 0.02 & 0.01 & 0.03 \\
\hline & 09-04-91 & 0950 & 1.10 & $<0.01$ & 0.7 & $<0.01$ & $<0.01$ & 0.02 \\
\hline & $09-04-91$ & 1535 & 1.10 & 0.03 & 0.3 & 0.02 & $<0.01$ & 0.02 \\
\hline & $09-04-91$ & 2205 & 1.10 & 0.05 & 0.3 & 0.02 & $<0.01$ & 0.02 \\
\hline & $11-23-91$ & 1300 & 0.75 & 0.10 & 0.4 & 0.03 & 0.02 & 0.04 \\
\hline & $11-25-91$ & 0910 & 0.75 & 0.07 & 0.4 & 0.03 & 0.01 & 0.07 \\
\hline & $01-15-92$ & 1035 & 1.90 & 0.02 & $<0.2$ & 0.01 & 0.03 & 0.05 \\
\hline & $01-23-92$ & 1350 & 1.20 & 0.02 & 0.2 & $<0.01$ & $<0.01$ & 0.03 \\
\hline & $01-25-92$ & 1005 & 1.10 & 0.03 & 0.3 & $<0.01$ & $<0.01$ & 0.05 \\
\hline & $01-28-92$ & 1130 & 1.00 & 0.02 & 0.2 & $<0.01$ & 0.01 & 0.01 \\
\hline & $01-31-92$ & 1515 & 1.10 & 0.02 & $<0.2$ & 0.02 & $<0.01$ & 0.02 \\
\hline & $02-04-92$ & 1050 & 1.20 & 0.02 & 0.6 & $<0.01$ & $<0.01$ & 0.06 \\
\hline & $02-21-92$ & 1005 & 1.30 & 0.03 & 0.4 & $<0.01$ & $<0.01$ & 0.03 \\
\hline & $02-27-92$ & 1010 & 1.40 & $<0.01$ & 0.5 & $<0.01$ & $<0.01$ & 0.04 \\
\hline & $03-24-92$ & 1045 & 1.40 & 0.04 & 0.5 & $<0.01$ & $<0.01$ & 0.03 \\
\hline & $04-21-92$ & 1015 & 1.40 & 0.03 & 0.3 & $<0.01$ & $<0.01$ & 0.03 \\
\hline \multirow[t]{5}{*}{500} & 01-04-91 & 1430 & 2.10 & 0.08 & 0.4 & $<0.01$ & $<0.01$ & 0.02 \\
\hline & $01-11-91$ & 1115 & 1.80 & 0.04 & 0.6 & $<0.01$ & 0.02 & 0.02 \\
\hline & $01-12-91$ & 1200 & 1.40 & 0.05 & 0.8 & $<0.01$ & 0.03 & 0.03 \\
\hline & $01-14-91$ & 1215 & 1.90 & 0.04 & 0.6 & 0.01 & 0.02 & 0.03 \\
\hline & $01-23-91$ & 0900 & 2.30 & 0.02 & 0.3 & 0.01 & 0.01 & 0.02 \\
\hline
\end{tabular}


Table A2.--Nitrogen and phosphorus data for the Clover Creek Basin, 1991-92--Continued

\begin{tabular}{|c|c|c|c|c|c|c|c|c|}
\hline $\begin{array}{l}\text { Site } \\
\text { num- } \\
\text { ber }^{1}\end{array}$ & Date & Time & $\begin{array}{l}\text { Nitrogen, } \\
\text { nitrite plus } \\
\text { nitrate, } \\
\text { dis- } \\
\text { solved } \\
\text { (mg/L } \\
\text { as } \mathrm{N} \text { ) }\end{array}$ & $\begin{array}{l}\text { Nitrogen, } \\
\text { ammonia } \\
\text { dis- } \\
\text { solved } \\
(\mathrm{mg} / \mathrm{L} \\
\text { as } \mathrm{N})\end{array}$ & $\begin{array}{l}\text { Nitrogen, } \\
\text { ammonia } \\
\text { plus } \\
\text { organic, } \\
\text { total } \\
(\mathrm{mg} / \mathrm{L} \\
\text { as } \mathrm{N})\end{array}$ & $\begin{array}{l}\text { Nitrogen, } \\
\text { nitrite, } \\
\text { dis- } \\
\text { solved } \\
(\mathrm{mg} / \mathrm{L} \\
\text { as } \mathrm{N})\end{array}$ & $\begin{array}{l}\text { Phos- } \\
\text { phorus, } \\
\text { ortho- } \\
\text { phosphate, } \\
\text { dissolved } \\
\text { (mg/L } \\
\text { as } \mathrm{P} \text { ) }\end{array}$ & $\begin{array}{l}\text { Phos- } \\
\text { phorus, } \\
\text { total } \\
\text { (mg/L } \\
\text { as } \mathrm{P})\end{array}$ \\
\hline \multirow[t]{32}{*}{500} & $02-01-91$ & 1415 & 2.00 & 0.01 & $<0.2$ & $<0.01$ & 0.04 & 0.02 \\
\hline & 02-03-91 & 1315 & 1.40 & 0.04 & 0.8 & $<0.01$ & 0.03 & 0.07 \\
\hline & $02-04-91$ & 1415 & 1.60 & 0.02 & 0.8 & $<0.01$ & 0.02 & 0.04 \\
\hline & $02-06-91$ & 0930 & 1.90 & 0.02 & 0.3 & 0.02 & 0.03 & 0.03 \\
\hline & 03-01-91 & 1015 & 2.00 & 0.03 & 0.3 & $<0.01$ & 0.01 & 0.03 \\
\hline & 03-02-91 & 1030 & 1.80 & 0.01 & 0.5 & 0.01 & $<0.01$ & 0.03 \\
\hline & 03-03-91 & 1515 & 1.30 & 0.02 & 0.4 & $<0.01$ & 0.02 & 0.03 \\
\hline & 03-04-91 & 1300 & 1.40 & 0.02 & 0.5 & $<0.01$ & $<0.01$ & 0.03 \\
\hline & $03-13-91$ & 1505 & 1.70 & $<0.01$ & 0.3 & $<0.01$ & 0.02 & 0.06 \\
\hline & $06-11-91$ & 0920 & 1.50 & 0.02 & 0.6 & 0.03 & $<0.01$ & 0.02 \\
\hline & $08-20-91$ & 0940 & 1.20 & 0.04 & 0.5 & $<0.01$ & 0.01 & 0.03 \\
\hline & $08-27-91$ & 0945 & 0.85 & 0.03 & 0.4 & 0.02 & $<0.01$ & 0.04 \\
\hline & $09-04-91$ & 0855 & 1.30 & 0.02 & 0.3 & 0.02 & 0.01 & 0.02 \\
\hline & 09-04-91 & 1450 & 1.10 & 0.04 & 0.2 & 0.01 & $<0.01$ & 0.02 \\
\hline & $09-04-91$ & 2105 & 1.30 & 0.04 & 0.3 & 0.01 & $<0.01$ & 0.02 \\
\hline & $10-16-91$ & 1100 & 1.30 & 0.36 & 1.1 & 0.01 & 0.06 & 0.11 \\
\hline & $11-23-91$ & 1045 & 0.25 & 0.21 & 0.6 & 0.02 & $<0.01$ & 0.04 \\
\hline & $11-25-91$ & 0810 & 0.81 & 0.04 & $<0.2$ & 0.01 & $<0.01$ & 0.04 \\
\hline & $01-10-92$ & 0945 & 1.40 & 0.12 & 0.9 & 0.02 & 0.03 & 0.10 \\
\hline & $01-15-92$ & 0830 & 0.64 & 0.04 & 0.4 & 0.01 & 0.01 & 0.06 \\
\hline & $01-23-92$ & 1030 & 1.30 & 0.02 & 0.2 & $<0.01$ & 0.02 & 0.04 \\
\hline & $01-23-92$ & 1930 & 1.10 & 0.03 & 0.5 & $<0.01$ & 0.03 & 0.08 \\
\hline & $01-25-92$ & 0930 & 1.40 & 0.02 & 0.4 & $<0.01$ & 0.02 & 0.04 \\
\hline & $01-28-92$ & 0915 & 1.10 & 0.03 & 1.0 & $<0.01$ & 0.03 & 0.12 \\
\hline & $01-29-92$ & 1345 & 1.60 & 0.06 & 0.6 & 0.02 & 0.03 & 0.06 \\
\hline & $01-31-92$ & 1600 & 1.40 & 0.03 & 0.6 & 0.01 & 0.03 & 0.08 \\
\hline & $02-04-92$ & 0915 & 1.70 & 0.03 & 0.4 & $<0.01$ & 0.02 & 0.03 \\
\hline & $02-19-92$ & 0945 & 1.70 & 0.04 & 0.4 & $<0.01$ & 0.02 & 0.05 \\
\hline & $02-21-92$ & 0845 & 1.30 & 0.01 & 0.5 & $<0.01$ & 0.01 & 0.05 \\
\hline & $02-27-92$ & 1125 & 2.10 & $<0.01$ & 0.2 & $<0.01$ & 0.02 & 0.02 \\
\hline & $03-24-92$ & 0855 & 1.90 & 0.02 & $<0.2$ & $<0.01$ & 0.01 & $<0.01$ \\
\hline & $04-21-92$ & 0830 & 1.60 & 0.03 & 0.3 & $<0.01$ & 0.02 & 0.03 \\
\hline \multirow[t]{7}{*}{602} & $01-11-91$ & 0930 & 1.80 & 0.05 & 0.6 & 0.01 & 0.04 & 0.03 \\
\hline & $01-23-91$ & 1045 & 2.20 & 0.01 & $<0.2$ & 0.02 & 0.02 & 0.03 \\
\hline & $02-03-91$ & 1245 & 1.20 & 0.04 & 0.7 & $<0.01$ & 0.03 & 0.08 \\
\hline & $02-04-91$ & 1520 & 1.60 & 0.01 & 0.4 & 0.01 & 0.03 & 0.02 \\
\hline & $02-06-91$ & 0850 & 1.90 & 0.02 & 0.4 & 0.01 & 0.03 & 0.04 \\
\hline & $03-01-91$ & 1115 & 2.00 & $<0.01$ & 0.5 & $<0.01$ & $<0.01$ & 0.03 \\
\hline & $03-02-91$ & 1115 & 1.70 & 0.01 & 0.5 & $<0.01$ & $<0.01$ & 0.03 \\
\hline
\end{tabular}


Table A2.--Nitrogen and phosphorus data for the Clover Creek Basin, 1991-92--Continued

\begin{tabular}{|c|c|c|c|c|c|c|c|c|}
\hline $\begin{array}{l}\text { Site } \\
\text { num- } \\
\text { ber }^{1}\end{array}$ & Date & Time & $\begin{array}{l}\text { Nitrogen, } \\
\text { nitrite plus } \\
\text { nitrate, } \\
\text { dis- } \\
\text { solved } \\
(\mathrm{mg} / \mathrm{L} \\
\text { as } \mathrm{N})\end{array}$ & $\begin{array}{l}\text { Nitrogen, } \\
\text { ammonia } \\
\text { dis- } \\
\text { solved } \\
(\mathrm{mg} / \mathrm{L} \\
\text { as } \mathrm{N})\end{array}$ & $\begin{array}{l}\text { Nitrogen, } \\
\text { ammonia } \\
\text { plus } \\
\text { organic, } \\
\text { total } \\
(\mathrm{mg} / \mathrm{L} \\
\text { as } \mathrm{N})\end{array}$ & $\begin{array}{l}\text { Nitrogen, } \\
\text { nitrite, } \\
\text { dis- } \\
\text { solved } \\
(\mathrm{mg} / \mathrm{L} \\
\text { as } \mathrm{N})\end{array}$ & $\begin{array}{l}\text { Phos- } \\
\text { phorus, } \\
\text { ortho- } \\
\text { phosphate, } \\
\text { dissolved } \\
\text { (mg/L } \\
\text { as } \mathrm{P} \text { ) }\end{array}$ & $\begin{array}{l}\text { Phos- } \\
\text { phorus, } \\
\text { total } \\
(\mathrm{mg} / \mathrm{L} \\
\text { as } \mathrm{P})\end{array}$ \\
\hline \multirow[t]{13}{*}{602} & $03-03-91$ & 1415 & 1.40 & 0.01 & $<0.2$ & $<0.01$ & 0.01 & 0.03 \\
\hline & $08-27-91$ & 0830 & 1.10 & 0.02 & 0.3 & 0.01 & $<0.01$ & 0.03 \\
\hline & 09-04-91 & 0805 & 1.20 & $<0.01$ & 0.7 & $<0.01$ & $<0.01$ & 0.02 \\
\hline & 09-04-91 & 1355 & 1.10 & 0.03 & 0.2 & 0.01 & $<0.01$ & 0.02 \\
\hline & 09-04-91 & 2010 & 1.20 & 0.04 & 0.2 & 0.01 & $<0.01$ & 0.02 \\
\hline & $11-24-91$ & 0915 & 1.10 & 0.02 & $<0.2$ & 0.02 & $<0.01$ & 0.02 \\
\hline & $01-25-92$ & 0910 & 1.40 & 0.02 & 0.4 & $<0.01$ & 0.01 & 0.08 \\
\hline & $01-28-92$ & 1000 & 0.95 & 0.03 & 0.7 & $<0.01$ & 0.03 & 0.10 \\
\hline & $02-04-92$ & 0820 & 1.70 & 0.02 & 0.4 & $<0.01$ & 0.02 & 0.05 \\
\hline & $02-21-92$ & 1605 & 1.50 & 0.03 & 0.4 & $<0.01$ & 0.02 & 0.04 \\
\hline & 03-24-92 & 0755 & 1.80 & 0.02 & $<0.2$ & $<0.01$ & $<0.01$ & $<0.01$ \\
\hline & $04-21-92$ & 0725 & 1.60 & 0.05 & 0.3 & $<0.01$ & 0.01 & 0.01 \\
\hline & \multicolumn{8}{|c|}{ Precipitation sites } \\
\hline \multirow[t]{3}{*}{1} & $11-23-91$ & 0800 & 0.08 & 0.10 & $<0.2$ & -- & -- & -- \\
\hline & $01-22-92$ & 1845 & 0.06 & 0.09 & $<0.2$ & -- & -- & -- \\
\hline & $02-20-92$ & 1200 & 0.06 & 0.09 & $<0.2$ & -- & -- & -- \\
\hline 2 & $11-23-91$ & 0800 & 0.06 & 0.06 & 0.3 & -- & -- & -- \\
\hline
\end{tabular}

${ }^{1}$ Site numbers, except for 1 and 2 for the two precipitation sites, are the last three digits of the eight-digit stream-flow station numbers assigned by the U.S. Geological Survey (for example, site 330 refers to station number 12090330). 
Table A3.--Temperature, $p H$, bacteria, dissolved oxygen, and biochemical oxygen demand data for the Clover Creek Basin, 1991-92

$\left[{ }^{\circ} \mathrm{C}\right.$, degrees Celsius; $\mathrm{mg} / \mathrm{L}$, milligrams per liter; $\mathrm{mL}$, milliliter; deg, degrees; cols. $/ 100 \mathrm{~mL}$, colonies per 100 milliliters; $\mathrm{K}$ indicates nonideal colony counts; <, less than; >, greater than; --, no data]

\begin{tabular}{|c|c|c|c|c|c|c|c|c|c|}
\hline $\begin{array}{l}\text { Site } \\
\text { num- } \\
\text { ber }^{1}\end{array}$ & Date & Time & $\begin{array}{l}\text { Temper- } \\
\text { ature } \\
\left({ }^{\circ} \mathrm{C}\right)\end{array}$ & $\begin{array}{l}\mathrm{pH} \\
\text { water, } \\
\text { whole- } \\
\text { field } \\
\text { (standard } \\
\text { units) }\end{array}$ & $\begin{array}{l}\text { Coliform, } \\
\text { fecal, } \\
\text { (cols./ } \\
100 \mathrm{~mL} \text { ) }\end{array}$ & $\begin{array}{l}\text { Strep- } \\
\text { tococci, } \\
\text { fecal, } \\
\text { (cols./ } \\
100 \mathrm{~mL} \text { ) }\end{array}$ & $\begin{array}{l}\text { Oxygen, } \\
\text { dis- } \\
\text { solved } \\
(\mathrm{mg} / \mathrm{L})\end{array}$ & $\begin{array}{l}\text { Oxygen } \\
\text { demand, } \\
\text { bio- } \\
\text { chemical, } \\
\text { 5-day } \\
(\mathrm{mg} / \mathrm{L})\end{array}$ & $\begin{array}{l}\text { Oxygen } \\
\text { demand, } \\
\text { bio- } \\
\text { chemical, } \\
\text { ultimate } \\
20 \mathrm{deg} . \\
(\mathrm{mg} / \mathrm{L})\end{array}$ \\
\hline \multirow[t]{3}{*}{325} & $06-26-91$ & 0815 & 9.5 & -- & -- & -- & -- & -- & -- \\
\hline & $03-24-92$ & 1250 & 8.5 & 6.9 & $<3$ & $<10$ & -- & -- & -- \\
\hline & $04-21-92$ & 1045 & 8.5 & 7.3 & K14 & K47 & -- & -- & -- \\
\hline \multirow[t]{23}{*}{330} & $01-23-91$ & 0845 & 6.5 & 7.1 & 23 & 20 & 9.1 & -- & -- \\
\hline & 03-02-91 & 1120 & 8.5 & 6.8 & 29 & 120 & .- & -- & -- \\
\hline & $06-11-91$ & 1445 & 12.0 & 7.1 & -- & -- & 9.5 & -- & -- \\
\hline & $06-26-91$ & 0850 & 11.5 & -- & -- & -- & -- & -- & -- \\
\hline & $08-27-91$ & 1020 & 11.5 & 7.1 & 280 & 910 & 8.2 & -- & - \\
\hline & 09-04-91 & 0940 & 11.0 & 7.1 & K60 & 700 & 8.2 & 1.5 & 1.8 \\
\hline & $09-04-91$ & 1250 & 12.5 & 7.1 & -- & -- & 8.7 & -- & -- \\
\hline & 09-04-91 & 1555 & 13.0 & 7.2 & -- & -- & 8.7 & 1.0 & 1.4 \\
\hline & 09-04-91 & 1835 & 13.0 & 7.2 & -- & -- & 8.6 & .- & -- \\
\hline & 09-04-91 & 2040 & 12.5 & $7: 2$ & -- & -- & 8.2 & 0.8 & 1.6 \\
\hline & 09-04-91 & 2345 & 12.0 & 7.3 & .- & -- & 7.7 & -- & -- \\
\hline & $09-05-91$ & 0245 & 11.5 & 7.2 & K59 & 240 & 7.9 & 1.1 & 1.6 \\
\hline & $11-23-91$ & 1630 & 8.5 & 7.0 & -- & -- & -- & -- & -- \\
\hline & 01-10-92 & 1230 & 9.0 & 7.2 & -- & -- & -- & -- & -- \\
\hline & $01-23-92$ & 1500 & 9.5 & 7.1 & -- & -- & -- & -- & -- \\
\hline & $01-25-92$ & 1100 & 9.0 & 7.1 & -- & -- & -- & -- & -- \\
\hline & $01-28-92$ & 1310 & 9.5 & 7.1 & -- & -- & -- & -- & -- \\
\hline & $02-04-92$ & 1230 & 8.0 & 7.0 & -- & -- & -- & -- & -- \\
\hline & $02-19-92$ & 1320 & 8.5 & 7.0 & -- & -- & -- & -- & -- \\
\hline & $02-21-92$ & 1400 & 10.0 & 7.0 & -- & -- & -- & -- & -- \\
\hline & $02-27-92$ & 0915 & 8.5 & 6.9 & -- & -- & -- & -- & -- \\
\hline & $03-24-92$ & 1350 & 10.0 & 7.2 & $<3$ & $<10$ & -- & -- & -- \\
\hline & $04-21-92$ & 1130 & 10.0 & 7.3 & K16 & K40 & -- & -- & -- \\
\hline \multirow[t]{2}{*}{335} & $06-26-91$ & 0940 & 12.0 & -- & -- & -- & -- & -- & -- \\
\hline & $04-21-92$ & 1100 & 10.5 & -- & -- & -- & -- & -- & -- \\
\hline \multirow[t]{7}{*}{340} & $01-31-91$ & 1215 & 5.0 & 6.8 & -- & -- & -- & -- & -- \\
\hline & $02-02-91$ & 2140 & 7.5 & 6.5 & -- & -- & -- & -- & -- \\
\hline & $02-03-91$ & 1030 & 7.0 & 6.5 & 210 & $>8,000$ & -- & -. & -- \\
\hline & 03-02-91 & 0500 & 7.0 & 6.7 & $\mathrm{~K} 1,200$ & $\mathrm{~K} 1,200$ & -- & -- & -- \\
\hline & $03-02-91$ & 0845 & 7.5 & 6.6 & 4,900 & 43,000 & -- & -- & -- \\
\hline & $03-02-91$ & 0855 & 7.5 & 6.5 & $\mathrm{~K} 7,300$ & 31,000 & -- & -- & -- \\
\hline & 03-02-91 & 1540 & 8.0 & 6.5 & -- & -- & -- & -- & -- \\
\hline
\end{tabular}


Table A3.--Temperature, $p H$, bacteria, dissolved oxygen, and biochemical oxygen demand data for the Clover Creek Basin, 1991-92--Continued

\begin{tabular}{|c|c|c|c|c|c|c|c|c|c|}
\hline $\begin{array}{l}\text { Site } \\
\text { num- } \\
\text { ber }{ }^{1}\end{array}$ & Date & Time & $\begin{array}{l}\text { Temper- } \\
\text { ature } \\
\left({ }^{\circ} \mathrm{C}\right)\end{array}$ & $\begin{array}{l}\text { pH } \\
\text { water, } \\
\text { whole- } \\
\text { field } \\
\text { (standard } \\
\text { units) }\end{array}$ & $\begin{array}{l}\text { Coliform, } \\
\text { fecal, } \\
\text { (cols./ } \\
100 \mathrm{~mL} \text { ) }\end{array}$ & $\begin{array}{l}\text { Strep- } \\
\text { tococci, } \\
\text { fecal, } \\
\text { (cols./ } \\
100 \mathrm{~mL} \text { ) }\end{array}$ & $\begin{array}{l}\text { Oxygen, } \\
\text { dis- } \\
\text { solved } \\
(\mathrm{mg} / \mathrm{L})\end{array}$ & $\begin{array}{l}\text { Oxygen } \\
\text { demand, } \\
\text { bio- } \\
\text { chemical, } \\
\text { 5-day } \\
(\mathrm{mg} / \mathrm{L})\end{array}$ & $\begin{array}{l}\text { Oxygen } \\
\text { demand, } \\
\text { bio- } \\
\text { chemical, } \\
\text { ultimate } \\
20 \mathrm{deg} . \\
(\mathrm{mg} / \mathrm{L})\end{array}$ \\
\hline \multirow[t]{10}{*}{340} & 03-03-91 & 0650 & 7.0 & 6.6 & $\mathrm{~K} 1,400$ & 3,900 & -- & -- & -- \\
\hline & $01-23-92$ & 1430 & 8.5 & 6.7 & -- & -- & -- & -- & -- \\
\hline & $01-28-92$ & 1030 & 9.0 & 6.4 & -- & -- & -- & -- & -- \\
\hline & $01-29-92$ & 0945 & 8.5 & 6.5 & -- & -- & -- & -- & -- \\
\hline & $01-30-92$ & 0815 & -- & 6.6 & -- & -- & -- & -- & -- \\
\hline & $01-31-92$ & 0945 & 9.5 & 6.5 & -- & -- & -- & -- & -- \\
\hline & $02-21-92$ & 0645 & 7.0 & 6.5 & 2,800 & 5,300 & -- & -- & -- \\
\hline & $02-21-92$ & 1410 & 11.5 & 6.6 & -- & -- & -- & -- & -. \\
\hline & $02-24-92$ & 0815 & 8.5 & 6.6 & -- & -- & -- & -- & -- \\
\hline & $03-24-92$ & 0825 & 9.0 & 6.7 & K58 & K 10 & -- & -- & -- \\
\hline \multirow[t]{29}{*}{355} & $01-12-91$ & 1030 & 8.0 & 7.0 & K31 & 1,100 & -- & -- & -- \\
\hline & $01-14-91$ & 0815 & 8.5 & 6.9 & K10 & $\mathrm{K} 25$ & -- & -- & -- \\
\hline & $01-23-91$ & 0745 & 5.5 & 7.2 & 47 & 53 & 8.9 & -- & -- \\
\hline & $02-03-91$ & 0930 & 8.5 & 7.1 & K23 & 2,700 & -- & -- & -- \\
\hline & 02-04-91 & 0940 & 9.5 & 7.0 & 83 & 170 & -- & -- & -- \\
\hline & $02-06-91$ & 1145 & 6.5 & 7.1 & K33 & K330 & -- & -- & -- \\
\hline & $03-01-91$ & 0820 & 8.0 & 7.0 & 65 & K40 & -- & -- & -- \\
\hline & $03-02-91$ & 1140 & 8.5 & 7.2 & 70 & 140 & -- & -- & -- \\
\hline & 03-03-91 & 0830 & 8.0 & 6.8 & -- & -- & -- & -- & -- \\
\hline & $03-04-91$ & 0900 & 7.5 & 7.0 & 120 & 170 & -- & -- & -- \\
\hline & $03-13-91$ & 1315 & 8.5 & 7.1 & -- & -- & -- & -- & -- \\
\hline & $06-11-91$ & 1345 & 14.0 & 7.3 & -- & -- & 9.5 & -- & -- \\
\hline & $06-26-91$ & 1035 & 13.5 & -- & -- & -- & -- & -- & -- \\
\hline & $08-27-91$ & 0915 & 14.0 & 7.1 & 450 & 3,800 & -- & -- & -- \\
\hline & 09-04-91 & 0850 & 14.0 & 7.2 & K53 & 370 & 5.8 & 1.5 & 1.8 \\
\hline & $09-04-91$ & 1145 & 14.0 & 7.1 & -- & -- & 7.8 & -- & -- \\
\hline & 09-04-91 & 1515 & 15.5 & 7.4 & -- & -- & -- & 1.4 & 1.9 \\
\hline & 09-04-91 & 1815 & 16.5 & 7.5 & -- & -- & 9.6 & -- & -- \\
\hline & 09-04-91 & 2015 & 17.0 & 7.4 & -- & -. & 9.0 & 1.2 & 2.2 \\
\hline & $09-04-91$ & 2320 & 16.5 & 7.3 & -- & -- & 6.7 & -- & -- \\
\hline & $09-05-91$ & 0215 & 15.5 & 7.2 & K29 & K190 & 5.6 & 1.0 & 1.9 \\
\hline & $11-23-91$ & 1515 & 6.0 & 7.4 & -- & -- & -- & -- & -- \\
\hline & $01-23-92$ & 1530 & 8.0 & 7.3 & -- & -- & -- & -- & -- \\
\hline & $01-25-92$ & 1200 & 8.5 & 7.1 & -- & -- & -- & -- & -- \\
\hline & $01-28-92$ & 1335 & 9.0 & 7.2 & -- & -- & -- & -- & -- \\
\hline & $02-04-92$ & 1315 & 7.0 & 7.0 & -- & -- & -- & -- & -- \\
\hline & $02-21-92$ & 1300 & 9.0 & 7.2 & -- & -- & -. & -- & -- \\
\hline & $03-24-92$ & 1440 & 11.0 & 7.3 & K3 & K85 & -- & -- & -- \\
\hline & $04-21-92$ & 1210 & 11.0 & 7.6 & K14 & K6 & -- & -- & -- \\
\hline
\end{tabular}


Table A3.--Temperature, $p H$, bacteria, dissolved oxygen, and biochemical oxygen demand data for the Clover Creek Basin, 1991-92--Continued

\begin{tabular}{|c|c|c|c|c|c|c|c|c|c|}
\hline $\begin{array}{l}\text { Site } \\
\text { num- } \\
\text { ber }^{1}\end{array}$ & Date & Time & $\begin{array}{l}\text { Temper- } \\
\text { ature } \\
\left({ }^{\circ} \mathrm{C}\right)\end{array}$ & $\begin{array}{l}\mathrm{pH} \\
\text { water, } \\
\text { whole- } \\
\text { field } \\
\text { (standard } \\
\text { units) }\end{array}$ & $\begin{array}{l}\text { Coliform, } \\
\text { fecal, } \\
\text { (cols./ } \\
100 \mathrm{~mL} \text { ) }\end{array}$ & $\begin{array}{l}\text { Strep- } \\
\text { tococci, } \\
\text { fecal, } \\
\text { (cols./ } \\
100 \mathrm{~mL} \text { ) }\end{array}$ & $\begin{array}{l}\text { Oxygen, } \\
\text { dis- } \\
\text { solved } \\
(\mathrm{mg} / \mathrm{L})\end{array}$ & $\begin{array}{l}\text { Oxygen } \\
\text { demand, } \\
\text { bio- } \\
\text { chemical, } \\
\text { 5-day } \\
(\mathrm{mg} / \mathrm{L})\end{array}$ & $\begin{array}{l}\text { Oxygen } \\
\text { demand, } \\
\text { bio- } \\
\text { chemical, } \\
\text { ultimate } \\
20 \mathrm{deg} . \\
(\mathrm{mg} / \mathrm{L})\end{array}$ \\
\hline \multirow[t]{2}{*}{358} & $06-26-91$ & 1225 & 14.0 & -- & -- & -- & -- & -- & -- \\
\hline & $04-21-92$ & 1230 & 11.0 & -- & -- & -- & -- & -- & -- \\
\hline \multirow[t]{14}{*}{360} & $01-12-91$ & 1200 & 8.0 & 7.1 & $\mathrm{~K} 10$ & K210 & -- & -. & -- \\
\hline & $01-23-91$ & 1040 & 5.0 & 7.5 & 14 & 50 & 11.5 & -- & -- \\
\hline & $02-03-91$ & 1510 & 9.0 & 7.4 & -- & -- & -- & -- & -. \\
\hline & $02-04-91$ & 0930 & 9.5 & 7.3 & 49 & 110 & -- & -- & -- \\
\hline & $02-06-91$ & 1240 & 7.0 & 7.5 & K19 & 80 & -- & -- & -- \\
\hline & 03-01-91 & 1145 & 7.5 & 7.4 & 34 & K39 & .- & .- & -- \\
\hline & 03-02-91 & 1210 & 8.0 & 7.3 & 39 & K55 & -- & -- & -- \\
\hline & 03-04-91 & 1145 & 7.5 & 7.1 & 48 & K60 & -- & -- & -- \\
\hline & $06-11-91$ & 1535 & 17.5 & 8.1 & -- & -- & 9.8 & -- & -- \\
\hline & $06-26-91$ & 1325 & 16.5 & -- & -- & -- & -- & -- & -- \\
\hline & $01-25-92$ & 1245 & 9.0 & 7.7 & -- & .- & -- & -- & .. \\
\hline & 02-04-92 & 1315 & 7.5 & 7.1 & -- & -- & -- & -- & -- \\
\hline & $03-24-92$ & 1250 & 11.0 & 7.8 & K58 & K210 & -- & -- & -- \\
\hline & $04-21-92$ & 1255 & 12.5 & 7.9 & 130 & K83 & -- & -- & -- \\
\hline \multirow[t]{22}{*}{365} & $01-31-91$ & 1245 & 1.5 & 7.2 & -- & -- & -- & -- & -- \\
\hline & $02-02-91$ & 2210 & 7.5 & 6.8 & -- & -- & -- & -- & -- \\
\hline & $02-03-91$ & 0850 & 6.0 & 6.9 & 63 & 460 & -- & -- & -- \\
\hline & $02-04-91$ & 1140 & 8.5 & 6.8 & K71 & K53 & -- & -- & -- \\
\hline & $03-01-91$ & 1215 & 6.5 & 7.2 & 61 & K19 & -- & -- & -- \\
\hline & 03-02-91 & 0540 & 6.0 & 7.1 & 600 & 850 & -- & -- & -- \\
\hline & 03-02-91 & 1520 & 8.0 & 7.2 & -- & -. & -- & -- & -- \\
\hline & 03-03-91 & 0815 & 6.0 & 6.8 & K940 & $\mathrm{K} 1,100$ & -- & -- & -- \\
\hline & 03-04-91 & 0945 & 5.0 & 6.7 & -- & -- & -- & -- & -- \\
\hline & $03-05-91$ & 1145 & 6.0 & 7.0 & -- & -- & -- & -- & -- \\
\hline & $01-10-92$ & 1320 & 7.0 & 6.8 & -- & -- & -- & -- & - \\
\hline & $01-22-92$ & 2035 & 5.0 & 7.1 & -- & -- & -- & -- & -- \\
\hline & $01-23-92$ & 1130 & 6.5 & 6.8 & -- & -- & -- & -- & -- \\
\hline & 01-24-92 & 1030 & 6.5 & 6.8 & -- & .- & -- & -- & -- \\
\hline & $01-28-92$ & 0945 & 7.5 & 7.0 & -- & -- & -- & -- & -- \\
\hline & $01-28-92$ & 1800 & 8.0 & 6.8 & -- & -- & -- & -- & -- \\
\hline & 01-29-92 & 0900 & 7.5 & 6.9 & -- & -- & -- & -- & -- \\
\hline & 01-31-92 & 0900 & 9.0 & 6.9 & -- & -- & -- & -- & -- \\
\hline & 02-04-92 & 0945 & 3.5 & 6.4 & -- & -- & -- & -. & -- \\
\hline & 02-19-92 & 1225 & 6.0 & 6.8 & -- & -- & -- & $-\cdot$ & -- \\
\hline & $02-21-92$ & 0730 & 6.0 & 6.9 & -- & -- & -- & -- & -- \\
\hline & $02-21-92$ & 1340 & 10.5 & 7.1 & 200 & 300 & -- & -- & -- \\
\hline
\end{tabular}


Table A3.--Temperature, $p H$, bacteria, dissolved oxygen, and biochemical oxygen demand data for the Clover Creek Basin, 1991-92--Continued

\begin{tabular}{|c|c|c|c|c|c|c|c|c|c|}
\hline $\begin{array}{l}\text { Site } \\
\text { num- } \\
\text { ber }^{1}\end{array}$ & Date & Time & $\begin{array}{l}\text { Temper- } \\
\text { ature } \\
\left({ }^{\circ} \mathrm{C}\right)\end{array}$ & $\begin{array}{l}\mathrm{pH} \\
\text { water, } \\
\text { whole- } \\
\text { field } \\
\text { (standard } \\
\text { units) }\end{array}$ & $\begin{array}{l}\text { Coliform, } \\
\text { fecal, } \\
\text { (cols. } \\
100 \mathrm{~mL} \text { ) }\end{array}$ & $\begin{array}{l}\text { Strep- } \\
\text { tococci, } \\
\text { fecal, } \\
\text { (cols./ } \\
100 \mathrm{~mL} \text { ) }\end{array}$ & $\begin{array}{l}\text { Oxygen, } \\
\text { dis- } \\
\text { solved } \\
(\mathrm{mg} / \mathrm{L})\end{array}$ & $\begin{array}{l}\text { Oxygen } \\
\text { demand, } \\
\text { bio- } \\
\text { chemical, } \\
\text { 5-day } \\
\text { (mg/L) }\end{array}$ & $\begin{array}{l}\text { Oxygen } \\
\text { demand, } \\
\text { bio- } \\
\text { chemical, } \\
\text { ultimate } \\
20 \mathrm{deg} . \\
(\mathrm{mg} / \mathrm{L})\end{array}$ \\
\hline \multirow[t]{3}{*}{365} & $02-24-92$ & 0850 & 7.5 & 6.8 & -- & -- & -- & -- & -- \\
\hline & $03-24-92$ & 0930 & 8.0 & 6.8 & 510 & 360 & -- & -- & -- \\
\hline & $04-21-92$ & 0845 & 8.5 & 7.1 & 360 & 240 & -- & -- & -- \\
\hline \multirow[t]{30}{*}{370} & $01-12-91$ & 1015 & 6.0 & 6.8 & $\mathrm{~K} 270$ & 2,600 & -- & -- & -- \\
\hline & $01-14-91$ & 0910 & 6.5 & 7.2 & -- & -- & -- & -- & -- \\
\hline & $01-23-91$ & 0910 & 2.5 & 7.7 & 48 & K120 & 12.9 & -- & -- \\
\hline & $02-01-91$ & 0830 & 4.0 & 7.2 & 73 & 720 & -- & -- & -- \\
\hline & $02-02-91$ & 2240 & 7.5 & 7.0 & -- & -- & -- & -- & -- \\
\hline & $02-03-91$ & 0950 & 6.5 & 7.1 & 200 & 4,000 & -- & -- & -- \\
\hline & 02-04-91 & 1000 & 8.0 & 7.2 & 260 & $\mathrm{~K} 1,200$ & -- & -- & -- \\
\hline & $03-01-91$ & 0900 & 5.5 & 7.5 & $\mathrm{~K} 15$ & 420 & -- & -- & -- \\
\hline & $03-02-91$ & 0610 & 6.5 & 7.4 & K680 & 820 & -- & -- & -- \\
\hline & $03-03-91$ & 0845 & 6.5 & 7.1 & 330 & 580 & -- & -- & -- \\
\hline & $03-04-91$ & 1030 & 6.0 & 7.0 & -- & -- & -- & -- & -- \\
\hline & $03-05-91$ & 1210 & 5.0 & 7.2 & -- & -- & -- & -- & -- \\
\hline & $11-23-91$ & 1150 & 6.0 & 7.8 & -- & -- & -- & -- & -- \\
\hline & $11-25-91$ & 1300 & 9.5 & 7.2 & 1,200 & 5,300 & - & -- & -- \\
\hline & $01-10-92$ & 1120 & 5.5 & 7.2 & -- & -- & -- & -- & -- \\
\hline & $01-23-92$ & 1045 & 6.5 & 7.1 & -- & -- & -- & -- & -- \\
\hline & $01-23-92$ & 2025 & 7.0 & 7.3 & -- & -- & -- & -- & -- \\
\hline & $01-24-92$ & 1000 & 7.0 & 7.1 & -- & -- & -- & -- & -- \\
\hline & $01-28-92$ & 0745 & 8.0 & 6.9 & -- & -- & -- & -- & -- \\
\hline & $01-28-92$ & 1130 & 8.5 & 7.1 & -- & -- & -- & -- & -- \\
\hline & $01-29-92$ & 1115 & 8.0 & 7.1 & -- & -- & -- & -- & -- \\
\hline & $01-30-92$ & 1940 & 8.5 & 6.9 & -- & -- & -- & -- & -- \\
\hline & $01-31-92$ & 1100 & -- & 6.9 & -- & -- & -- & -- & -- \\
\hline & $02-04-92$ & 1015 & 5.0 & 7.0 & -- & -- & -- & -- & -- \\
\hline & $02-20-92$ & 1240 & 6.5 & 7.2 & -- & -- & -- & -- & -- \\
\hline & $02-21-92$ & 0630 & 6.0 & 7.2 & 190 & 870 & -. & -- & -- \\
\hline & $02-21-92$ & 1125 & 7.5 & 7.3 & 520 & 1,500 & -- & -- & -- \\
\hline & $02-24-92$ & 0925 & 7.5 & 7.1 & -- & -- & -- & -- & -- \\
\hline & $03-24-92$ & 1435 & 11.5 & 7.8 & K63 & $\mathrm{K} 170$ & -- & -- & -- \\
\hline & $04-21-92$ & 1245 & 11.0 & 7.8 & 410 & 240 & -. & -- & -- \\
\hline \multirow[t]{5}{*}{380} & $01-31-91$ & 1345 & 4.0 & 6.8 & - & -. & -- & -- & -- \\
\hline & $02-02-91$ & 2100 & 7.5 & 6.9 & -- & -- & -- & -- & -- \\
\hline & $02-03-91$ & 0815 & 6.5 & 6.8 & K770 & K12,000 & -- & -- & - \\
\hline & $02-04-91$ & 1215 & 8.5 & 6.8 & $\mathrm{~K} 850$ & $\mathrm{~K} 1,300$ & -- & -- & -- \\
\hline & $02-06-91$ & 1115 & 4.5 & 6.8 & 700 & $\mathrm{~K} 290$ & -- & -- & -- \\
\hline
\end{tabular}


Table A3.--Temperature, pH, bacteria, dissolved oxygen, and biochemical oxygen demand data for the Clover Creek Basin, 1991-92--Continued

\begin{tabular}{|c|c|c|c|c|c|c|c|c|c|}
\hline $\begin{array}{l}\text { Site } \\
\text { num- } \\
\text { ber }^{1}\end{array}$ & Date & Time & $\begin{array}{l}\text { Temper- } \\
\text { ature } \\
\left({ }^{\circ} \mathrm{C}\right)\end{array}$ & $\begin{array}{l}\mathrm{pH} \\
\text { water, } \\
\text { whole- } \\
\text { field } \\
\text { (standard } \\
\text { units) }\end{array}$ & $\begin{array}{l}\text { Coliform, } \\
\text { fecal, } \\
\text { (cols./ } \\
100 \mathrm{~mL} \text { ) }\end{array}$ & $\begin{array}{l}\text { Strep- } \\
\text { tococci, } \\
\text { fecal, } \\
\text { (cols./ } \\
100 \mathrm{~mL} \text { ) }\end{array}$ & $\begin{array}{l}\text { Oxygen, } \\
\text { dis- } \\
\text { solved } \\
\text { (mg/L) }\end{array}$ & $\begin{array}{l}\text { Oxygen } \\
\text { demand, } \\
\text { bio- } \\
\text { chemical, } \\
5 \text {-day } \\
(\mathrm{mg} / \mathrm{L})\end{array}$ & $\begin{array}{l}\text { Oxygen } \\
\text { demand, } \\
\text { bio- } \\
\text { chemical, } \\
\text { ultimate } \\
20 \mathrm{deg} \text {. } \\
(\mathrm{mg} / \mathrm{L})\end{array}$ \\
\hline \multirow[t]{13}{*}{395} & $01-24-92$ & 0930 & 7.0 & 7.1 & -- & -- & -- & -. & -- \\
\hline & $01-28-92$ & 0715 & 8.0 & 6.9 & -- & -- & -- & -- & -. \\
\hline & $01-28-92$ & 1200 & 8.5 & 7.1 & -- & -- & -- & -- & -- \\
\hline & $01-29-92$ & 1145 & 8.0 & 7.1 & -- & -- & -- & -- & -- \\
\hline & $01-30-92$ & 2005 & 8.5 & 6.9 & -- & -- & -- & -- & -- \\
\hline & $01-31-92$ & 1130 & 9.0 & 7.1 & -- & -- & -- & -- & -- \\
\hline & $02-04-92$ & 1030 & 5.5 & 7.1 & -- & -- & -- & -- & -- \\
\hline & $02-20-92$ & 1315 & 7.0 & 6.9 & -- & -- & -- & -- & -- \\
\hline & $02-21-92$ & 0550 & 6.5 & 7.4 & -- & -- & -- & -- & -- \\
\hline & $02-21-92$ & 1050 & 7.5 & 7.2 & 2,000 & 2,400 & -- & -- & -- \\
\hline & $02-24-92$ & 1000 & 8.0 & 7.1 & 4,500 & 5,500 & -- & -- & -- \\
\hline & $03-24-92$ & 1350 & 11.5 & 8.2 & 93 & $\mathrm{~K} 120$ & -- & -- & -- \\
\hline & $04-21-92$ & 1315 & 12.0 & 7.8 & 150 & 630 & -- & -- & -- \\
\hline \multirow[t]{25}{*}{400} & $01-12-91$ & 0845 & 6.0 & 7.0 & $<10$ & 4,400 & -- & -- & -- \\
\hline & $01-12-91$ & 1400 & 7.5 & 7.1 & 620 & 2,300 & -- & -- & -- \\
\hline & $01-14-91$ & 1005 & 7.0 & 7.1 & K77 & $\mathrm{K} 120$ & -- & -- & -- \\
\hline & $01-23-91$ & 1010 & 3.5 & 7.6 & 70 & 67 & 12.0 & -. & -- \\
\hline & $02-02-91$ & 2330 & 7.5 & 7.1 & -- & -- & -- & -- & -- \\
\hline & $02-03-91$ & 1525 & 8.0 & 7.2 & -- & -- & -- & -- & -- \\
\hline & $02-04-91$ & 0820 & 8.0 & 7.3 & 420 & K900 & -- & - & -- \\
\hline & $02-06-91$ & 1215 & 5.5 & 7.3 & 120 & $\mathrm{~K} 150$ & -- & -- & -- \\
\hline & $03-01-91$ & 1115 & 6.0 & 7.7 & K69 & 240 & -- & -- & -- \\
\hline & $03-02-91$ & 0735 & 6.5 & 7.4 & $\mathrm{~K} 1,400$ & $\mathrm{~K} 1,200$ & -- & -- & -- \\
\hline & $03-02-91$ & 1425 & 7.5 & 7.6 & -- & -- & -- & -- & -- \\
\hline & $03-03-91$ & 0930 & 7.0 & 7.1 & 2,100 & 2,400 & -- & -- & -- \\
\hline & $03-04-91$ & 1300 & 6.5 & 6.9 & -- & -- & -- & -- & -- \\
\hline & $03-05-91$ & 1245 & 5.5 & 7.4 & -- & -- & -- & -- & -- \\
\hline & $11-23-91$ & 1400 & 6.5 & 7.7 & -- & -- & -- & -- & -- \\
\hline & $11-24-91$ & 0845 & 8.0 & 7.6 & 230 & 1,300 & -- & -- & -. \\
\hline & $01-10-92$ & 0945 & 6.0 & 7.4 & -- & -- & - & -- & -- \\
\hline & $01-22-92$ & 2000 & 5.5 & 7.5 & -- & -- & -. & -- & -- \\
\hline & $01-23-92$ & 0830 & 6.5 & 7.3 & -- & -- & -- & -- & -- \\
\hline & $01-23-92$ & 1920 & 7.5 & 7.4 & -- & -- & -- & -- & -- \\
\hline & $01-24-92$ & 0900 & 7.0 & 7.1 & -- & -- & -. & -- & -- \\
\hline & $01-28-92$ & 0535 & 8.0 & -- & -- & -- & -- & -- & -- \\
\hline & $01-28-92$ & 1300 & 8.5 & 7.2 & -- & -- & - & -- & -- \\
\hline & $01-29-92$ & 1215 & 8.0 & 7.1 & -- & -- & -- & -- & -- \\
\hline & $01-30-92$ & 2030 & 8.5 & 6.9 & -- & -- & -- & -- & -- \\
\hline
\end{tabular}


Table A3.--Temperature, $p H$, bacteria, dissolved oxygen, and biochemical oxygen demand data for the Clover Creek Basin, 1991-92--Continued

\begin{tabular}{|c|c|c|c|c|c|c|c|c|c|}
\hline $\begin{array}{l}\text { Site } \\
\text { num- } \\
\text { ber } 1\end{array}$ & Date & Time & $\begin{array}{l}\text { Temper- } \\
\text { ature } \\
\left({ }^{\circ} \mathrm{C}\right)\end{array}$ & $\begin{array}{l}\text { pH } \\
\text { water, } \\
\text { whole- } \\
\text { field } \\
\text { (standard } \\
\text { units) }\end{array}$ & $\begin{array}{l}\text { Coliform, } \\
\text { fecal, } \\
\text { (cols./ } \\
100 \mathrm{~mL} \text { ) }\end{array}$ & $\begin{array}{l}\text { Strep- } \\
\text { tococci, } \\
\text { fecal, } \\
\text { (cols./ } \\
100 \mathrm{~mL})\end{array}$ & $\begin{array}{l}\text { Oxygen, } \\
\text { dis- } \\
\text { solved } \\
\text { (mg/L) }\end{array}$ & $\begin{array}{l}\text { Oxygen } \\
\text { demand, } \\
\text { bio- } \\
\text { chemical, } \\
\text { 5-day } \\
(\mathrm{mg} / \mathrm{L})\end{array}$ & $\begin{array}{l}\text { Oxygen } \\
\text { demand, } \\
\text { bio- } \\
\text { chemical, } \\
\text { ultimate } \\
20 \mathrm{deg} . \\
(\mathrm{mg} / \mathrm{L})\end{array}$ \\
\hline \multirow[t]{13}{*}{395} & $01-24-92$ & 0930 & 7.0 & 7.1 & - & - & -- & -- & -. \\
\hline & $01-28-92$ & 0715 & 8.0 & 6.9 & -- & - & -- & -- & - \\
\hline & $01-28-92$ & 1200 & 8.5 & 7.1 & -- & -- & -- & -- & -- \\
\hline & $01-29-92$ & 1145 & 8.0 & 7.1 & -- & -. & -- & -- & -. \\
\hline & $01-30-92$ & 2005 & 8.5 & 6.9 & -- & -- & -- & -- & -- \\
\hline & $01-31-92$ & 1130 & 9.0 & 7.1 & -- & -. & -- & -- & -. \\
\hline & $02-04-92$ & 1030 & 5.5 & 7.1 & -- & -- & -- & -- & -- \\
\hline & $02-20-92$ & 1315 & 7.0 & 6.9 & -- & -- & -- & -- & -- \\
\hline & $02-21-92$ & 0550 & 6.5 & 7.4 & -- & -- & -- & -- & -- \\
\hline & $02-21-92$ & 1050 & 7.5 & 7.2 & 2,000 & 2,400 & -- & -- & -- \\
\hline & $02-24-92$ & 1000 & 8.0 & 7.1 & 4,500 & 5,500 & -- & - & -- \\
\hline & $03-24-92$ & 1350 & 11.5 & 8.2 & 93 & K120 & -- & -- & -- \\
\hline & $04-21-92$ & 1315 & 12.0 & 7.8 & 150 & 630 & -- & -- & -- \\
\hline \multirow[t]{25}{*}{400} & $01-12-91$ & 0845 & 6.0 & 7.0 & $<10$ & 4,400 & -- & -- & -- \\
\hline & $01-12-91$ & 1400 & 7.5 & 7.1 & 620 & 2,300 & -- & -- & -- \\
\hline & $01-14-91$ & 1005 & 7.0 & 7.1 & K77 & $\mathrm{K} 120$ & -- & -- & -- \\
\hline & $01-23-91$ & 1010 & 3.5 & 7.6 & 70 & 67 & 12.0 & -- & -- \\
\hline & $02-02-91$ & 2330 & 7.5 & 7.1 & -- & -- & - & - & - \\
\hline & $02-03-91$ & 1525 & 8.0 & 7.2 & -- & -- & -- & -- & -- \\
\hline & $02-04-91$ & 0820 & 8.0 & 7.3 & 420 & K900 & -- & -- & - \\
\hline & $02-06-91$ & 1215 & 5.5 & 7.3 & 120 & $\mathrm{~K} 150$ & -- & -- & -- \\
\hline & $03-01-91$ & 1115 & 6.0 & 7.7 & K69 & 240 & -- & -- & -- \\
\hline & $03-02-91$ & 0735 & 6.5 & 7.4 & $\mathrm{~K} 1,400$ & $\mathrm{~K} 1,200$ & -- & -- & -- \\
\hline & $03-02-91$ & 1425 & 7.5 & 7.6 & -- & -- & -- & -. & -- \\
\hline & $03-03-91$ & 0930 & 7.0 & 7.1 & 2,100 & 2,400 & -- & -- & -- \\
\hline & $03-04-91$ & 1300 & 6.5 & 6.9 & -- & -- & -- & -- & -- \\
\hline & $03-05-91$ & 1245 & 5.5 & 7.4 & -- & -- & -- & -- & -- \\
\hline & $11-23-91$ & 1400 & 6.5 & 7.7 & -- & -- & -- & -- & -- \\
\hline & $11-24-91$ & 0845 & 8.0 & 7.6 & 230 & 1,300 & - & -- & -- \\
\hline & $01-10-92$ & 0945 & 6.0 & 7.4 & -- & -- & -- & -- & -- \\
\hline & $01-22-92$ & 2000 & 5.5 & 7.5 & -. & -- & -- & -- & -- \\
\hline & $01-23-92$ & 0830 & 6.5 & 7.3 & -- & -- & -- & -- &.- \\
\hline & $01-23-92$ & 1920 & 7.5 & 7.4 & -- & -- & -- & -- & -- \\
\hline & $01-24-92$ & 0900 & 7.0 & 7.1 & -- & -- & -- & -- & -- \\
\hline & $01-28-92$ & 0535 & 8.0 & -- & -- & -- & -. & -- & -- \\
\hline & $01-28-92$ & 1300 & 8.5 & 7.2 & -- & -- & -- & -- & -- \\
\hline & $01-29-92$ & 1215 & 8.0 & 7.1 & - & -- & -- & -. & -- \\
\hline & $01-30-92$ & 2030 & 8.5 & 6.9 & -- & -- & -- & -- & -- \\
\hline
\end{tabular}


Table A3.--Temperature, $p H$, bacteria, dissolved oxygen, and biochemical oxygen demand data for the Clover Creek Basin, 1991-92--Continued

\begin{tabular}{|c|c|c|c|c|c|c|c|c|c|}
\hline $\begin{array}{l}\text { Site } \\
\text { num- } \\
\text { ber }^{1}\end{array}$ & Date & Time & $\begin{array}{l}\text { Temper- } \\
\text { ature } \\
\left({ }^{\circ} \mathrm{C}\right)\end{array}$ & $\begin{array}{l}\mathrm{pH} \\
\text { water, } \\
\text { whole- } \\
\text { field } \\
\text { (standard } \\
\text { units) }\end{array}$ & $\begin{array}{l}\text { Coliform, } \\
\text { fecal, } \\
\text { (cols./ } \\
100 \mathrm{~mL} \text { ) }\end{array}$ & $\begin{array}{l}\text { Strep- } \\
\text { tococci, } \\
\text { fecal, } \\
\text { (cols./ } \\
100 \mathrm{~mL} \text { ) }\end{array}$ & $\begin{array}{l}\text { Oxygen, } \\
\text { dis- } \\
\text { solved } \\
(\mathrm{mg} / \mathrm{L})\end{array}$ & $\begin{array}{l}\text { Oxygen } \\
\text { demand, } \\
\text { bio- } \\
\text { chemical, } \\
5 \text {-day } \\
(\mathrm{mg} / \mathrm{L})\end{array}$ & $\begin{array}{l}\text { Oxygen } \\
\text { demand, } \\
\text { bio- } \\
\text { chemical, } \\
\text { ultimate } \\
20 \text { deg. } \\
(\mathrm{mg} / \mathrm{L})\end{array}$ \\
\hline \multirow[t]{8}{*}{400} & $01-31-92$ & 1200 & 9.0 & 7.2 & -- & -- & -. & -- & -- \\
\hline & $02-04-92$ & 1100 & 5.5 & 7.2 & -- & -- & -- & -- & -- \\
\hline & $02-19-92$ & 1115 & 5.5 & 7.1 & -- & -- & -- & -- & -- \\
\hline & $02-21-92$ & 0520 & 6.5 & 7.9 & 1,300 & 770 & -- & -- & -- \\
\hline & $02-21-92$ & 1300 & 8.5 & 7.3 & -- & -- & -- & -- & -- \\
\hline & $02-24-92$ & 1045 & 8.5 & 7.1 & -- & -- & -- & -- & -- \\
\hline & $03-24-92$ & 1320 & 11.5 & 8.5 & $\mathrm{~K} 22$ & K130 & -- & -- & -- \\
\hline & $04-21-92$ & 1340 & & & & & & & \\
\hline \multirow[t]{27}{*}{430} & $01-11-91$ & 1230 & 5.5 & 7.4 & K120 & 2,200 & -- & -- & -- \\
\hline & $01-12-91$ & 0910 & 6.5 & 7.0 & -. & 8,100 & -- & -- & -- \\
\hline & $01-12-91$ & 1400 & 7.5 & 7.1 & K300 & 3,100 & -- & -- & -- \\
\hline & $01-14-91$ & 1050 & 8.0 & 7.1 & -- & -- & $\cdots$ & -- & -- \\
\hline & $01-23-91$ & 1415 & 8.0 & 7.2 & K47 & K71 & 12.0 & -- & -- \\
\hline & $02-01-91$ & 0930 & 7.5 & 6.8 & 100 & $\mathrm{~K} 1,400$ & -- & -- & -- \\
\hline & $02-03-91$ & 0005 & 7.5 & 7.3 & -- & -- & -- & -- & -- \\
\hline & $02-03-91$ & 1410 & 7.5 & 7.3 & -- & -- & -- & -- & -- \\
\hline & $02-04-91$ & 1230 & 8.5 & 7.2 & K570 & 2,100 & -- & -- & -- \\
\hline & $02-06-91$ & 1015 & 6.0 & 7.2 & 93 & 250 & -- & -- & -- \\
\hline & 03-01-91 & 0900 & 7.5 & 7.1 & K16 & $\mathrm{K} 27,000$ & -- & -- & -- \\
\hline & $03-02-91$ & 0915 & 7.5 & 7.2 & $\mathrm{~K} 1,100$ & 3,200 & -- & -- & -- \\
\hline & $03-03-91$ & 1600 & 8.0 & 7.3 & -- & -- & -- & -- & -- \\
\hline & $03-04-91$ & 1210 & 6.5 & 7.3 & K620 & 890 & -- & -- & -- \\
\hline & $03-05-91$ & 1310 & 6.5 & 7.3 & -- & -- & -- & -- & -- \\
\hline & $11-24-91$ & 1015 & 7.5 & 6.5 & 730 & $\mathrm{~K} 15,000$ & -. & -- & -- \\
\hline & $11-25-91$ & 1010 & 9.0 & 7.5 & $\mathrm{~K} 2,000$ & $\mathrm{~K} 13,000$ & -- & -- & -- \\
\hline & $01-10-92$ & 1045 & 6.0 & 7.5 & -- & -- & - & -- & -- \\
\hline & $01-23-92$ & 1215 & 7.0 & 7.3 & -- & -- & -- & -- & -- \\
\hline & $01-23-92$ & 2025 & 7.5 & 7.1 & -- & -- & -- & -- & -- \\
\hline & $01-25-92$ & 0930 & 7.0 & 7.4 & -- & -- & -- & -- & -- \\
\hline & $01-28-92$ & 1100 & 8.5 & 7.3 & -- & -- & -- & -- & -- \\
\hline & $01-31-92$ & 1400 & 9.5 & 7.3 & -- & -- & -- & -- & -- \\
\hline & $02-04-92$ & 1225 & 6.5 & 7.5 & -- & -- & -- & -- & -- \\
\hline & $02-21-92$ & 1000 & 7.0 & 7.2 & 1,700 & 1,000 & -- & -- & -- \\
\hline & $02-24-92$ & 1120 & 9.5 & 7.2 & -- & -- & -- & -- & -- \\
\hline & $04-21-92$ & 1110 & 12.0 & 9.0 & 230 & 180 & -- & -- & -- \\
\hline 448 & $06-26-91$ & 0834 & 12.5 & -- & -- & -- & -- & -. & -- \\
\hline
\end{tabular}


Table A3.--Temperature, $p H$, bacteria, dissolved oxygen, and biochemical oxygen demand data for the Clover Creek Basin, 1991-92--Continued

\begin{tabular}{|c|c|c|c|c|c|c|c|c|c|}
\hline $\begin{array}{l}\text { Site } \\
\text { num- } \\
\text { ber }^{1}\end{array}$ & Date & Time & $\begin{array}{l}\text { Temper- } \\
\text { ature } \\
\left({ }^{\circ} \mathrm{C}\right)\end{array}$ & $\begin{array}{l}\mathrm{pH} \\
\text { water, } \\
\text { whole- } \\
\text { field } \\
\text { (standard } \\
\text { units) }\end{array}$ & $\begin{array}{l}\text { Coliform, } \\
\text { fecal, } \\
\text { (cols./ } \\
100 \mathrm{~mL} \text { ) }\end{array}$ & $\begin{array}{l}\text { Strep- } \\
\text { tococci, } \\
\text { fecal, } \\
\text { (cols./ } \\
100 \mathrm{~mL} \text { ) }\end{array}$ & $\begin{array}{l}\text { Oxygen, } \\
\text { dis- } \\
\text { solved } \\
(\mathrm{mg} / \mathrm{L})\end{array}$ & $\begin{array}{l}\text { Oxygen } \\
\text { demand, } \\
\text { bio- } \\
\text { chemical, } \\
5 \text {-day } \\
(\mathrm{mg} / \mathrm{L})\end{array}$ & $\begin{array}{l}\text { Oxygen } \\
\text { demand, } \\
\text { bio- } \\
\text { chemical, } \\
\text { ultimate } \\
20 \mathrm{deg} . \\
(\mathrm{mg} / \mathrm{L})\end{array}$ \\
\hline \multirow[t]{28}{*}{452} & $01-11-91$ & 1320 & 4.5 & 7.4 & K10 & K330 & -- & -- & -- \\
\hline & $01-23-91$ & 1300 & 5.0 & 7.1 & 31 & K33 & 9.9 & -- & -- \\
\hline & 02-03-91 & 1435 & 6.0 & 7.2 & -- & -- & -- & -- & -- \\
\hline & $02-04-91$ & 1130 & 6.5 & 7.3 & K160 & 67 & -- & -- & -- \\
\hline & $02-06-91$ & 1320 & 6.0 & 7.3 & K40 & 120 & -- & -- & -- \\
\hline & 03-01-91 & 1300 & 8.0 & 7.3 & 27 & K8 & -- & -- & -- \\
\hline & $03-02-91$ & 1410 & 8.5 & 7.4 & 37 & K41 & -- & -- & -- \\
\hline & 03-04-91 & 0950 & 7.5 & 7.4 & 47 & 29 & -- & -- & -- \\
\hline & 03-13-91 & 1400 & 8.0 & 7.3 & -- & -- & -- & -- & -- \\
\hline & $06-11-91$ & 1235 & 17.5 & 8.1 & -- & -- & 11.2 & -- & -- \\
\hline & $06-26-91$ & 0910 & 18.0 & -- & -- & -- & -- & -- & -- \\
\hline & $08-27-91$ & 0810 & 20.5 & 7.9 & 150 & 350 & 10.0 & -- & -- \\
\hline & 09-04-91 & 0810 & 18.5 & 7.7 & 310 & 120 & 8.8 & 3.1 & 4.1 \\
\hline & 09-04-91 & 1120 & 19.5 & 7.6 & -- & -- & 9.9 & -- & -- \\
\hline & $09-04-91$ & 1430 & 21.0 & 8.2 & -- & -- & 10.3 & 1.9 & 3.2 \\
\hline & 09-04-91 & 1730 & 21.5 & 8.6 & -- & -- & 11.6 & -- & -- \\
\hline & 09-04-91 & 1945 & 21.5 & 8.6 & -- & -- & 10.6 & 2.0 & 4.2 \\
\hline & 09-04-91 & 2255 & 20.5 & 8.9 & -- & -- & 11.0 & -- & -- \\
\hline & $09-05-91$ & 0150 & 20.0 & 8.5 & 200 & 190 & 10.0 & 1.8 & 3.1 \\
\hline & $11-24-91$ & 1045 & 8.5 & 7.3 & -- & -- & - & -- & -- \\
\hline & $01-15-92$ & 0945 & 5.5 & 7.5 & -- & -- & -- & -- & -- \\
\hline & $01-23-92$ & 1315 & 6.0 & 7.3 & -- & -- & -- & -- & -- \\
\hline & $01-25-92$ & 1020 & 6.0 & 7.4 & -- & -- & -- & -- & -- \\
\hline & $01-28-92$ & 1200 & 7.0 & 7.5 & -- & -- & -- & -- & -- \\
\hline & $02-04-92$ & 1010 & 7.0 & 7.2 & -- & -- & -- & -- & -- \\
\hline & $02-21-92$ & 1500 & 8.5 & 7.3 & -- & -- & -- & -- & -- \\
\hline & $03-24-92$ & 0955 & 11.5 & 7.7 & 77 & K160 & -- & -- & -- \\
\hline & $04-21-92$ & 0935 & 13.5 & 7.8 & 130 & K20 & -- & -- & -- \\
\hline \multirow[t]{10}{*}{460} & $06-11-91$ & 1100 & 17.0 & 7.5 & -- & -- & 9.8 & -- & -- \\
\hline & $06-26-91$ & 1055 & 17.0 & -- & -- & -- & -- & -- & -- \\
\hline & $08-27-91$ & 1145 & 19.0 & 7.7 & 83 & K200 & 10.3 & -- & -- \\
\hline & 09-04-91 & 1025 & 19.5 & 7.6 & 390 & 290 & 11.0 & 3.5 & 5.2 \\
\hline & 09-04-91 & 1240 & 19.5 & 7.4 & -- & -- & 10.3 & -- & -- \\
\hline & $09-04-91$ & 1645 & 21.0 & 8.3 & -- & -- & 12.9 & 2.8 & 4.7 \\
\hline & 09-04-91 & 1910 & 21.0 & 8.5 & -- & -- & 13.8 & -- & -- \\
\hline & $09-04-91$ & 2210 & 21.0 & 8.9 & -- & -- & 13.4 & 2.7 & 4.6 \\
\hline & $09-05-91$ & 0110 & 20.0 & 8.7 & -- & -- & 12.8 & -- & -- \\
\hline & $09-05-91$ & 0420 & 19.5 & 8.2 & K14 & K24 & 11.6 & 3.0 & 5.8 \\
\hline
\end{tabular}


Table A3.--Temperature, $p H$, bacteria, dissolved oxygen, and biochemical oxygen demand data for the Clover Creek Basin, 1991-92--Continued

\begin{tabular}{|c|c|c|c|c|c|c|c|c|c|}
\hline $\begin{array}{l}\text { Site } \\
\text { num- } \\
\text { ber }^{1}\end{array}$ & Date & Time & $\begin{array}{l}\text { Temper- } \\
\text { ature } \\
\left({ }^{\circ} \mathrm{C}\right)\end{array}$ & $\begin{array}{l}\mathrm{pH} \\
\text { water, } \\
\text { whole- } \\
\text { field } \\
\text { (standard } \\
\text { units) }\end{array}$ & $\begin{array}{l}\text { Coliform, } \\
\text { fecal, } \\
\text { (cols./ } \\
100 \mathrm{~mL} \text { ) }\end{array}$ & $\begin{array}{l}\text { Strep- } \\
\text { tococci, } \\
\text { fecal, } \\
\text { (cols./ } \\
100 \mathrm{~mL} \text { ) }\end{array}$ & $\begin{array}{l}\text { Oxygen, } \\
\text { dis- } \\
\text { solved } \\
(\mathrm{mg} / \mathrm{L})\end{array}$ & $\begin{array}{l}\text { Oxygen } \\
\text { demand, } \\
\text { bio- } \\
\text { chemical, } \\
5 \text {-day } \\
(\mathrm{mg} / \mathrm{L})\end{array}$ & $\begin{array}{l}\text { Oxygen } \\
\text { demand, } \\
\text { bio- } \\
\text { chemical, } \\
\text { ultimate } \\
20 \mathrm{deg} \text {. } \\
(\mathrm{mg} / \mathrm{L})\end{array}$ \\
\hline \multirow[t]{12}{*}{460} & $11-23-91$ & 1400 & 7.0 & 7.3 & -- & -- & -- & -- & -- \\
\hline & $11-25-91$ & 1005 & 9.0 & 7.1 & $\mathrm{~K} 100$ & 210 & -- & -- & -- \\
\hline & $01-15-92$ & 1130 & 6.5 & 7.3 & -- & -- & -- & -- & -- \\
\hline & $01-23-92$ & 1245 & 6.5 & 7.4 & -- & -- & -- & -- & -- \\
\hline & $01-25-92$ & 1110 & 7.5 & 7.4 & -- & -- & -- & -- & -- \\
\hline & $01-28-92$ & 1355 & 8.5 & 7.5 & -- & -- & -- & -- & -- \\
\hline & $01-31-92$ & 1430 & 9.0 & 7.3 & -- & -- & -- & -- & -- \\
\hline & $02-04-92$ & 1140 & 7.5 & 7.0 & -- & -- & -- & -- & -- \\
\hline & $02-21-92$ & 1115 & 9.0 & 7.3 & K37 & K18 & -- & -- & -- \\
\hline & $02-27-92$ & 1040 & 9.0 & 7.2 & -- & -- & -- & -- & -- \\
\hline & $03-24-92$ & 1135 & 12.0 & 7.4 & $\mathrm{~K} 22$ & K54 & -- & -- & -- \\
\hline & $04-21-92$ & 1215 & 14.0 & 7.8 & $\mathrm{~K} 18$ & K15 & -- & -- & -- \\
\hline \multirow[t]{26}{*}{480} & $03-01-91$ & 1345 & 8.0 & 7.3 & 32 & K43 & -- & -- & -- \\
\hline & $03-02-91$ & 1315 & 9.0 & 7.3 & K53 & 97 & -- & -- & -- \\
\hline & 03-03-91 & 1630 & 9.0 & 7.3 & -- & -- & -- & -- & -- \\
\hline & $03-04-91$ & 1035 & 7.5 & 7.3 & 54 & K44 & -- & -- & -- \\
\hline & $06-11-91$ & 1135 & 16.0 & 7.4 & -- & -- & 10.0 & -- & -- \\
\hline & $06-26-91$ & 1009 & 16.5 & -- & -- & -- & -- & -- & -- \\
\hline & $08-27-91$ & 1110 & 17.0 & 7.0 & K650 & 2,200 & 7.4 & -- & -- \\
\hline & 09-04-91 & 0950 & 16.5 & 7.1 & 180 & 970 & 9.7 & 1.9 & 2.2 \\
\hline & 09-04-91 & 1220 & 18.0 & 7.2 & -. & -- & 10.0 & -- & -- \\
\hline & $09-04-91$ & 1535 & 19.0 & 7.2 & -- & -- & 10.0 & 1.5 & 2.4 \\
\hline & $09-04-91$ & 1850 & 19.0 & 7.0 & -- & -- & 8.9 & -- & -- \\
\hline & $09-04-91$ & 2205 & 18.0 & 7.0 & -- & -- & 7.6 & 1.8 & 2.6 \\
\hline & $09-05-91$ & 0130 & 17.0 & 7.2 & -- & -- & 7.4 & -- & -- \\
\hline & $09-05-91$ & 0430 & 16.0 & 7.2 & 200 & 500 & 7.6 & 1.3 & 2.6 \\
\hline & $11-23-91$ & 1300 & 6.0 & 7.4 & -- & -- & -- & -- & - \\
\hline & $11-25-91$ & 0910 & 9.0 & 7.0 & $\mathrm{~K} 140$ & 1,700 & -- & -- & -- \\
\hline & $01-15-92$ & 1035 & 6.5 & 7.3 & -- & -- & -- & -- & -- \\
\hline & $01-23-92$ & 1350 & 8.0 & 7.3 & -- & -- & -- & -- & -- \\
\hline & $01-25-92$ & 1005 & 7.0 & 7.2 & -- & -- & -- & -- & -- \\
\hline & $01-28-92$ & 1130 & 8.5 & 7.3 & -- & -- & -- & -- & -- \\
\hline & $01-31-92$ & 1515 & 9.0 & 7.3 & -- & -- & -- & -- & -- \\
\hline & $02-04-92$ & 1050 & 6.5 & 7.1 & -- & -- & -- & -- & -- \\
\hline & $02-21-92$ & 1005 & 8.0 & 7.3 & K44 & K43 & -- & -. & -- \\
\hline & $02-27-92$ & 1010 & 9.0 & 7.1 & -- & -- & -- & -- & -- \\
\hline & $03-24-92$ & 1045 & 11.0 & 7.4 & $\mathrm{~K} 44$ & K64 & -- & -- & -- \\
\hline & $04-21-92$ & 1015 & 13.5 & 7.4 & 100 & K37 & -- & -- & -- \\
\hline
\end{tabular}


Table A3.--Temperature, $\mathrm{pH}$, bacteria, dissolved oxygen, and biochemical oxygen demand data for the Clover Creek Basin, 1991-92--Continued

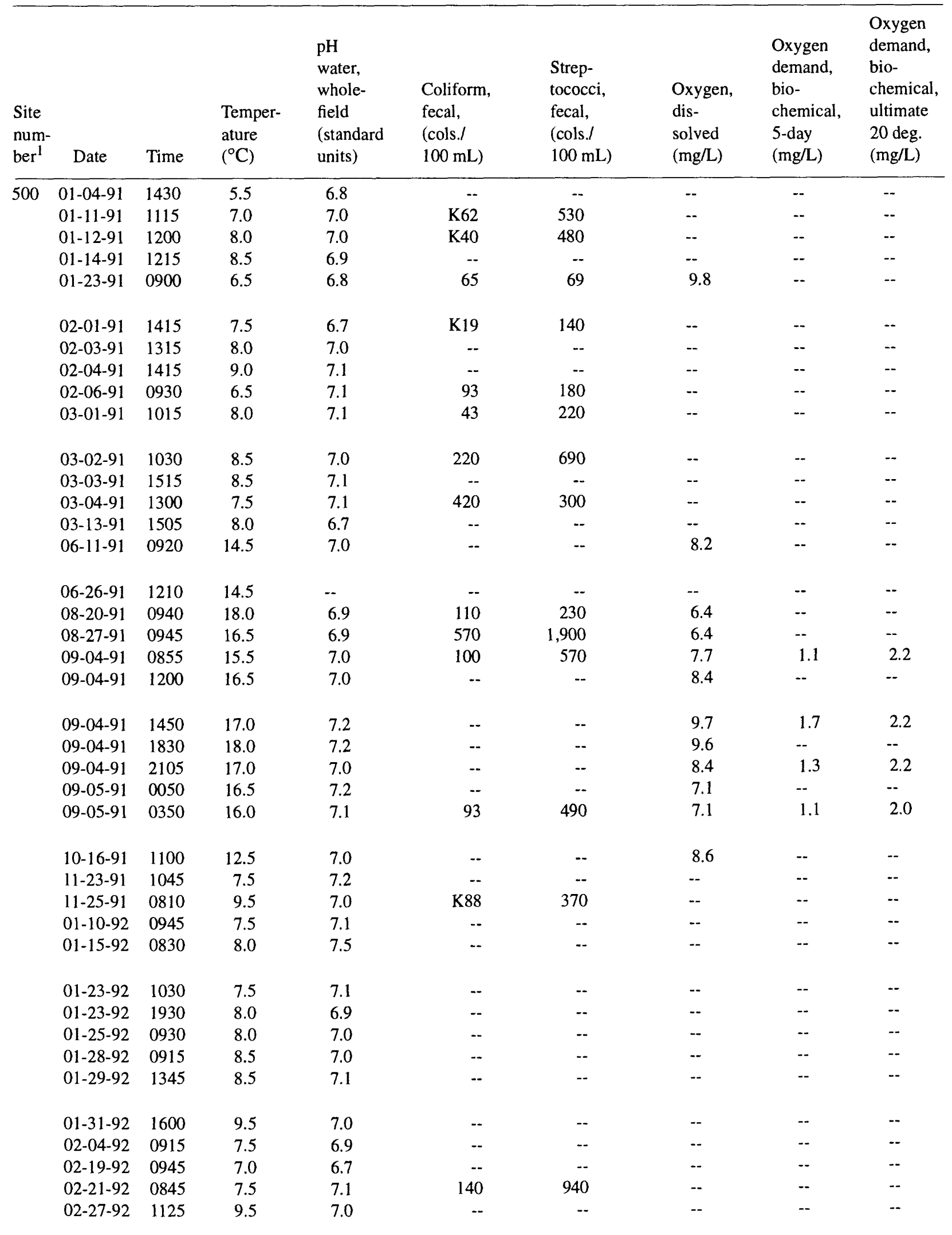


Table A3.--Temperature, $p H$, bacteria, dissolved oxygen, and biochemical oxygen demand data for the Clover Creek Basin, 1991-92--Continued

\begin{tabular}{|c|c|c|c|c|c|c|c|c|c|}
\hline $\begin{array}{l}\text { Site } \\
\text { num- } \\
\text { ber }^{1}\end{array}$ & Date & Time & $\begin{array}{l}\text { Temper- } \\
\text { ature } \\
\left({ }^{\circ} \mathrm{C}\right)\end{array}$ & $\begin{array}{l}\mathrm{pH} \\
\text { water, } \\
\text { whole- } \\
\text { field } \\
\text { (standard } \\
\text { units) }\end{array}$ & $\begin{array}{l}\text { Coliform, } \\
\text { fecal, } \\
\text { (cols./ } \\
100 \mathrm{~mL} \text { ) }\end{array}$ & $\begin{array}{l}\text { Strep- } \\
\text { tococci, } \\
\text { fecal, } \\
\text { (cols./ } \\
100 \mathrm{~mL} \text { ) }\end{array}$ & $\begin{array}{l}\text { Oxygen, } \\
\text { dis- } \\
\text { solved } \\
(\mathrm{mg} / \mathrm{L})\end{array}$ & $\begin{array}{l}\text { Oxygen } \\
\text { demand, } \\
\text { bio- } \\
\text { chemical, } \\
\text { 5-day } \\
(\mathrm{mg} / \mathrm{L})\end{array}$ & $\begin{array}{l}\text { Oxygen } \\
\text { demand, } \\
\text { bio- } \\
\text { chemical, } \\
\text { ultimate } \\
20 \text { deg. } \\
(\mathrm{mg} / \mathrm{L})\end{array}$ \\
\hline \multirow[t]{2}{*}{500} & $03-24-92$ & 0855 & 11.0 & 7.1 & 310 & 390 & -- & -- & -- \\
\hline & $04-21-92$ & 0830 & 11.5 & 7.2 & K75 & 110 & -- & -- & -- \\
\hline \multirow[t]{24}{*}{602} & $01-11-91$ & 0930 & 7.0 & 7.3 & K46 & 590 & -- & -- & -- \\
\hline & $01-23-91$ & 1045 & 6.5 & 7.1 & 67 & K40 & 11.1 & -- & -- \\
\hline & 02-03-91 & 1245 & 8.5 & 7.2 & -- & -- & -- & -- & -- \\
\hline & $02-04-91$ & 1520 & 9.0 & 7.2 & -- & -- & -- & -- & -- \\
\hline & $02-06-91$ & 0850 & 6.5 & 7.2 & K58 & 160 & -- & -- & -- \\
\hline & 03-01-91 & 1115 & 8.0 & 7.2 & 43 & 170 & -- & -- & -- \\
\hline & $03-02-91$ & 1115 & 8.5 & 7.2 & 210 & 570 & -- & -- & -- \\
\hline & 03-03-91 & 1415 & 8.5 & 7.1 & -- & -- & -- & -- & -- \\
\hline & $06-26-91$ & 1303 & 15.0 & -- & -- & -- & -- & -- & -- \\
\hline & $08-27-91$ & 0830 & 16.5 & 7.3 & 1,200 & 2,000 & 8.3 & -- & -- \\
\hline & $09-04-91$ & 0805 & 15.0 & 7.3 & 210 & 790 & -- & 1.8 & 2.4 \\
\hline & 09-04-91 & 1130 & 16.5 & 7.5 & -- & -- & 10.3 & -- & -- \\
\hline & 09-04-91 & 1355 & 18.0 & 7.8 & -- & -- & 10.4 & 1.5 & 2.3 \\
\hline & 09-04-91 & 1800 & 18.0 & 7.7 & -- & -- & 9.9 & -- & -- \\
\hline & $09-04-91$ & 2010 & 17.5 & 7.6 & -- & -- & 9.4 & 1.2 & 2.4 \\
\hline & 09-05-91 & 0020 & 17.0 & 7.5 & -- & -- & 8.8 & -- & -- \\
\hline & $09-05-91$ & 0330 & 16.0 & 7.5 & 460 & 780 & 9.0 & 0.9 & 1.5 \\
\hline & $11-24-91$ & 0915 & 8.5 & 7.3 & -- & -- & -- & -- & -- \\
\hline & $01-25-92$ & 0910 & 8.0 & 7.3 & -- & -- & -- & -- & -- \\
\hline & $01-28-92$ & 1000 & 8.0 & 7.1 & -- & -- & -- & -- & -- \\
\hline & $02-04-92$ & 0820 & 7.5 & 7.2 & -- & -- & -- & -- & -- \\
\hline & $02-21-92$ & 1605 & 9.0 & 7.3 & -- & -- & -- & -- & -- \\
\hline & $03-24-92$ & 0755 & 10.5 & 7.2 & 400 & 950 & -- & -- & -- \\
\hline & $04-21-92$ & 0725 & 11.0 & 7.3 & 130 & K51 & -- & -- & -- \\
\hline \multicolumn{10}{|c|}{ Precipitation sites } \\
\hline \multirow[t]{3}{*}{1} & $11-23-91$ & 0800 & -- & -- & -- & -- & -- & -- & -- \\
\hline & $01-22-92$ & 1845 & -- & -- & -- & -- & -- & -- & -- \\
\hline & $02-20-92$ & 1200 & -- & -- & -- & -- & -- & -- & -- \\
\hline 2 & $11-23-91$ & 0800 & -- & -- & -- & -- & -- & -- & -- \\
\hline
\end{tabular}

\footnotetext{
${ }^{1}$ Site numbers, except for 1 and 2 for the two precipitation sites, are the last three digits of the eight-digit station numbers assigned by the U.S. Geological Survey (for example, site 330 refers to station number 12090330).
} 
Table A4.--Copper, lead, and zinc data for the Clover Creek Basin, 1991-92

[ $\mu \mathrm{g} / \mathrm{L}$, micrograms per liter; <, less than; --, no data available]

\begin{tabular}{|c|c|c|c|c|c|c|c|c|}
\hline $\begin{array}{l}\text { Site } \\
\text { num- } \\
\text { ber }^{1}\end{array}$ & Date & Time & $\begin{array}{l}\text { Copper, } \\
\text { dis- } \\
\text { solved } \\
(\mu \mathrm{g} / \mathrm{L} \\
\text { as } \mathrm{Cu})\end{array}$ & $\begin{array}{l}\text { Copper, } \\
\text { total } \\
\text { recov- } \\
\text { erable } \\
(\mu \mathrm{g} / \mathrm{L} \\
\text { as } \mathrm{Cu})\end{array}$ & $\begin{array}{l}\text { Lead, } \\
\text { dis- } \\
\text { solved } \\
(\mu \mathrm{g} / \mathrm{L} \\
\text { as } \mathrm{Pb})\end{array}$ & $\begin{array}{l}\text { Lead, } \\
\text { total } \\
\text { recov- } \\
\text { erable } \\
(\mu \mathrm{g} / \mathrm{L} \\
\text { as } \mathrm{Pb})\end{array}$ & $\begin{array}{l}\text { Zinc, } \\
\text { dis- } \\
\text { solved } \\
(\mu \mathrm{g} / \mathrm{L} \\
\text { as } \mathrm{Zn})\end{array}$ & $\begin{array}{l}\text { Zinc, } \\
\text { total } \\
\text { recov- } \\
\text { erable } \\
(\mu \mathrm{g} / \mathrm{L} \\
\text { as } \mathrm{Zn})\end{array}$ \\
\hline \multirow[t]{2}{*}{330} & $11-23-91$ & 1630 & $<1$ & -- & $<1$ & $<1$ & $<10$ & 20 \\
\hline & $01-23-92$ & 1500 & $<1$ & 3 & $<1$ & $<1$ & $<10$ & 10 \\
\hline \multirow[t]{2}{*}{340} & $01-23-92$ & 1430 & 3 & 5 & $<1$ & 10 & 20 & 20 \\
\hline & $02-21-92$ & 0645 & 2 & 5 & $<1$ & 54 & 10 & 50 \\
\hline \multirow[t]{2}{*}{355} & $11-23-91$ & 1515 & 1 & -- & $<1$ & 31 & $<10$ & 20 \\
\hline & $01-23-92$ & 1530 & $<1$ & 2 & $<1$ & $<1$ & $<10$ & $<10$ \\
\hline \multirow[t]{2}{*}{365} & $01-23-92$ & 1130 & 2 & 4 & 1 & 2 & 30 & 20 \\
\hline & $02-21-92$ & 0730 & 2 & $<1$ & $<1$ & 1 & $<10$ & 10 \\
\hline \multirow[t]{4}{*}{370} & $11-23-91$ & 1150 & 2 & -- & $<1$ & 3 & $<10$ & 40 \\
\hline & 01-23-92 & 1045 & 2 & 4 & $<1$ & 1 & 20 & 20 \\
\hline & $01-28-92$ & 0745 & 2 & 3 & $<1$ & 6 & 20 & 30 \\
\hline & $02-21-92$ & 0630 & 2 & 1 & $<1$ & $<1$ & $<10$ & 20 \\
\hline \multirow[t]{3}{*}{380} & $02-02-91$ & 2100 & -- & 8 & -- & 13 & -- & 40 \\
\hline & 01-23-92 & 1230 & 4 & 9 & $<1$ & 1 & 30 & 20 \\
\hline & $02-21-92$ & 0830 & 2 & 4 & $<1$ & 4 & 20 & 30 \\
\hline \multirow[t]{4}{*}{395} & $11-23-91$ & 1330 & 3 & -- & $<1$ & 10 & $<10$ & 40 \\
\hline & $01-23-92$ & 0930 & 2 & 6 & $<1$ & 12 & 70 & 70 \\
\hline & $01-28-92$ & 0715 & 3 & 4 & $<1$ & 12 & 30 & 110 \\
\hline & $02-21-92$ & 0550 & 2 & 4 & $<1$ & 4 & 20 & 30 \\
\hline \multirow[t]{5}{*}{400} & $01-12-91$ & 1400 & -- & 3 & -- & 3 & -- & 40 \\
\hline & $11-23-91$ & 1400 & 3 & -- & $<1$ & 2 & $<10$ & 40 \\
\hline & $11-24-91$ & 0845 & 3 & -- & $<1$ & 7 & $<10$ & 30 \\
\hline & $01-23-92$ & 0830 & 4 & 23 & 4 & 11 & 70 & 140 \\
\hline & $02-21-92$ & 0520 & 2 & 4 & $<1$ & 3 & 10 & 20 \\
\hline \multirow[t]{5}{*}{430} & $01-11-91$ & 1230 & -- & 3 & -- & 8 & -- & 20 \\
\hline & $11-24-91$ & 1015 & 3 & -- & 1 & 14 & 20 & 60 \\
\hline & $01-23-92$ & 1215 & 3 & 5 & $<1$ & 10 & 10 & 40 \\
\hline & $01-28-92$ & 1100 & 2 & 5 & $<1$ & 8 & 20 & 30 \\
\hline & $02-21-92$ & 1000 & 3 & 10 & $<1$ & 8 & $<10$ & 40 \\
\hline \multirow[t]{2}{*}{452} & $11-24-91$ & 1045 & 2 & -- & $<1$ & $<1$ & $<10$ & 30 \\
\hline & $01-23-92$ & 1315 & 1 & 6 & $<1$ & $<1$ & $<10$ & $<10$ \\
\hline \multirow[t]{3}{*}{460} & $11-23-91$ & 1400 & 2 & -- & $<1$ & $<1$ & $<10$ & 20 \\
\hline & $01-23-92$ & 1245 & 1 & 3 & $<1$ & $<1$ & $<10$ & 20 \\
\hline & $01-28-92$ & 1355 & $<1$ & 3 & $<1$ & 3 & 10 & 10 \\
\hline
\end{tabular}


Table A4.--Copper, lead, and zinc data for the Clover Creek Basin, 1991-92--Continued

\begin{tabular}{|c|c|c|c|c|c|c|c|c|}
\hline $\begin{array}{l}\text { Site } \\
\text { num- } \\
\text { ber }^{1}\end{array}$ & Date & Time & $\begin{array}{l}\text { Copper, } \\
\text { dis- } \\
\text { solved } \\
(\mu \mathrm{g} / \mathrm{L} \\
\text { as } \mathrm{Cu})\end{array}$ & $\begin{array}{l}\text { Copper, } \\
\text { total } \\
\text { recov- } \\
\text { erable } \\
(\mu \mathrm{g} / \mathrm{L} \\
\text { as } \mathrm{Cu})\end{array}$ & $\begin{array}{l}\text { Lead, } \\
\text { dis- } \\
\text { solved } \\
(\mu \mathrm{g} / \mathrm{L} \\
\text { as } \mathrm{Pb})\end{array}$ & $\begin{array}{l}\text { Lead, } \\
\text { total } \\
\text { recov- } \\
\text { erable } \\
(\mu \mathrm{g} / \mathrm{L} \\
\text { as } \mathrm{Pb})\end{array}$ & $\begin{array}{l}\text { Zinc, } \\
\text { dis- } \\
\text { solved } \\
(\mu \mathrm{g} / \mathrm{L} \\
\text { as } \mathrm{Zn})\end{array}$ & $\begin{array}{l}\text { Zinc, } \\
\text { total } \\
\text { recov- } \\
\text { erable } \\
(\mu \mathrm{g} / \mathrm{L} \\
\text { as } \mathrm{Zn})\end{array}$ \\
\hline \multirow[t]{3}{*}{480} & $11-23-91$ & 1300 & 2 & -- & $<1$ & 6 & $<10$ & 50 \\
\hline & $01-23-92$ & 1350 & 1 & 4 & $<1$ & 1 & $<10$ & $<10$ \\
\hline & $01-28-92$ & 1130 & $<1$ & 3 & $<1$ & 2 & $<10$ & $<10$ \\
\hline \multirow[t]{4}{*}{500} & $10-16-91$ & 1100 & 5 & 4 & 2 & 10 & 40 & 30 \\
\hline & $11-23-91$ & 1045 & 2 & -- & $<1$ & 3 & $<10$ & 30 \\
\hline & $01-23-92$ & 1030 & 2 & 4 & $<1$ & 2 & 10 & $<10$ \\
\hline & $01-28-92$ & 0915 & 2 & 3 & $<1$ & 8 & 10 & 20 \\
\hline \multirow[t]{2}{*}{602} & $11-24-91$ & 0915 & 2 & -- & $<1$ & $<1$ & 20 & 40 \\
\hline & $01-28-92$ & 1000 & 2 & 3 & $<1$ & 8 & $<10$ & 30 \\
\hline
\end{tabular}

${ }^{1}$ Site numbers are the last three digits of the eight-digit stream-flow station numbers assigned by the U.S. Geological Survey (for example, site 330 refers to station number 12090330). 
Table A5.--Fine-grained (less than 63 micrometers in diameter) streambed-sediment data for the Clover Creek Basin, 1991-92

$[\mu \mathrm{g} / \mathrm{g}$, micrograms per gram; $<$, less than; --, no data]

\begin{tabular}{lcccccccc}
\hline $\begin{array}{l}\text { Site } \\
\text { num- } \\
\text { ber }^{1}\end{array}$ & Date & Time & $\begin{array}{l}\text { Aluminum, } \\
\text { percent }\end{array}$ & $\begin{array}{l}\text { Arsenic, } \\
(\mu \mathrm{g} / \mathrm{g})\end{array}$ & $\begin{array}{l}\text { Barium, } \\
(\mu \mathrm{g} / \mathrm{g})\end{array}$ & $\begin{array}{l}\text { Beryllium, } \\
(\mu \mathrm{g} / \mathrm{g})\end{array}$ & $\begin{array}{l}\text { Bismuth, } \\
(\mu \mathrm{g} / \mathrm{g})\end{array}$ & $\begin{array}{l}\text { Cadmium, } \\
(\mu \mathrm{g} / \mathrm{g})\end{array}$ \\
\hline 330 & $06-11-91$ & 1445 & 3.1 & $<10$ & 190 & $<1$ & $<10$ & $<2$ \\
480 & $06-12-91$ & 1130 & 3.7 & $<10$ & 210 & $<1$ & $<10$ & $<2$ \\
500 & $06-12-91$ & 1320 & 3.9 & $<10$ & 240 & $<1$ & $<10$ & $<2$ \\
602 & $06-12-91$ & 1430 & 3.4 & $<10$ & 190 & $<1$ & $<10$ & $<2$
\end{tabular}

\begin{tabular}{lcccccccc}
\hline $\begin{array}{l}\text { Site } \\
\text { num- } \\
\text { ber }^{1}\end{array}$ & Date & Time & $\begin{array}{l}\text { Calcium, } \\
\text { percent }\end{array}$ & $\begin{array}{l}\text { Cerium, } \\
(\mu \mathrm{g} / \mathrm{g})\end{array}$ & $\begin{array}{l}\text { Chromium, } \\
(\mu \mathrm{g} / \mathrm{g})\end{array}$ & $\begin{array}{l}\text { Cobalt, } \\
(\mu \mathrm{g} / \mathrm{g})\end{array}$ & $\begin{array}{l}\text { Copper, } \\
(\mu \mathrm{g} / \mathrm{g})\end{array}$ & $\begin{array}{l}\text { Europium, } \\
(\mu \mathrm{g} / \mathrm{g})\end{array}$ \\
\hline 330 & $06-11-91$ & 1445 & 1.9 & 9 & 65 & 5 & 25 & $<2$ \\
480 & $06-12-91$ & 1130 & 1.7 & 14 & 58 & 7 & 94 & $<2$ \\
500 & $06-12-91$ & 1320 & 1.5 & 17 & 70 & 9 & 53 & $<2$ \\
602 & $06-12-91$ & 1430 & 1.4 & 12 & 58 & 7 & 53
\end{tabular}

\begin{tabular}{lcccccccc}
\hline $\begin{array}{l}\text { Site } \\
\text { num- } \\
\text { ber }^{1}\end{array}$ & Date & Time & $\begin{array}{l}\text { Gallium, } \\
(\mu \mathrm{g} / \mathrm{g})\end{array}$ & $\begin{array}{l}\text { Gold, } \\
(\mu \mathrm{g} / \mathrm{g})\end{array}$ & $\begin{array}{l}\text { Holmium, } \\
(\mu \mathrm{g} / \mathrm{g})\end{array}$ & $\begin{array}{l}\text { Iron, } \\
\text { percent }\end{array}$ & $\begin{array}{l}\text { Lanthanum, } \\
(\mu \mathrm{g} / \mathrm{g})\end{array}$ & $\begin{array}{l}\text { Lead, } \\
(\mu \mathrm{g} / \mathrm{g})\end{array}$ \\
\hline 330 & $06-11-91$ & 1445 & 6 & $<8$ & $<4$ & 1.1 & 7 & 23 \\
480 & $06-12-91$ & 1130 & 8 & $<8$ & $<4$ & 1.9 & 9 & 1.8 \\
500 & $06-12-91$ & 1320 & 8 & $<8$ & $<4$ & 1.4 & 9 & 170 \\
602 & $06-12-91$ & 1430 & 6 & $<8$ & $<4$ & 180
\end{tabular}

\begin{tabular}{|c|c|c|c|c|c|c|c|c|}
\hline $\begin{array}{l}\text { Site } \\
\text { num- } \\
\text { ber }^{1}\end{array}$ & Date & Time & $\begin{array}{l}\text { Lithium, } \\
(\mu \mathrm{g} / \mathrm{g})\end{array}$ & $\begin{array}{l}\text { Magnesium, } \\
\text { percent }\end{array}$ & $\begin{array}{l}\text { Manganese, } \\
(\mu \mathrm{g} / \mathrm{g})\end{array}$ & $\begin{array}{l}\text { Molybdenum, } \\
(\mu \mathrm{g} / \mathrm{g})\end{array}$ & $\begin{array}{l}\text { Neodymium, } \\
(\mu \mathrm{g} / \mathrm{g})\end{array}$ & $\begin{array}{l}\text { Nickel, } \\
(\mu \mathrm{g} / \mathrm{g})\end{array}$ \\
\hline 330 & $06-11-91$ & 1445 & 10 & 0.53 & 310 & $<2$ & 8 & 19 \\
\hline 480 & $06-12-91$ & 1130 & 16 & 0.61 & 650 & $<2$ & 9 & 23 \\
\hline 500 & $06-12-91$ & 1320 & 13 & 0.61 & 440 & 3 & 12 & 31 \\
\hline 602 & $06-12-91$ & 1430 & 11 & 0.56 & 330 & 3 & 9 & 26 \\
\hline
\end{tabular}


Table A5.--Fine-grained (less than 63 micrometers in diameter) streambed-sediment data for the Clover Creek Basin, 1991-92--Continued

\begin{tabular}{lccllllrr}
\hline $\begin{array}{l}\text { Site } \\
\text { num- } \\
\text { ber }^{1}\end{array}$ & Date & Time & $\begin{array}{l}\text { Niobium, } \\
(\mu \mathrm{g} / \mathrm{g})\end{array}$ & $\begin{array}{l}\text { Phosphorus, } \\
\text { percent }\end{array}$ & $\begin{array}{l}\text { Potassium, } \\
\text { percent }\end{array}$ & $\begin{array}{l}\text { Scandium, } \\
(\mu \mathrm{g} / \mathrm{g})\end{array}$ & $\begin{array}{l}\text { Silver, } \\
(\mu \mathrm{g} / \mathrm{g})\end{array}$ & $\begin{array}{l}\text { Sodium, } \\
\text { percent }\end{array}$ \\
\hline 330 & $06-11-91$ & 1445 & $<4$ & 0.12 & 0.37 & 5 & $<4$ & 0.88 \\
480 & $06-12-91$ & 1130 & $<4$ & 0.19 & 0.42 & 7 & 8 & 0.91 \\
500 & $06-12-91$ & 1320 & $<4$ & 0.19 & 0.43 & 6 & 0.83 \\
602 & $06-12-91$ & 1430 & $<4$ & 0.17 & 0.40 & $<4$ & 0.73
\end{tabular}

\begin{tabular}{lccllllll}
\hline $\begin{array}{l}\text { Site } \\
\text { num- } \\
\text { ber }^{1}\end{array}$ & Date & Time & $\begin{array}{l}\text { Strontium, } \\
(\mu \mathrm{g} / \mathrm{g})\end{array}$ & $\begin{array}{l}\text { Tantalum, } \\
(\mu \mathrm{g} / \mathrm{g})\end{array}$ & $\begin{array}{l}\text { Thorium, } \\
(\mu \mathrm{g} / \mathrm{g})\end{array}$ & $\begin{array}{l}\text { Tin, } \\
(\mu \mathrm{g} / \mathrm{g})\end{array}$ & $\begin{array}{l}\text { Titanium, } \\
\text { percent }\end{array}$ & $\begin{array}{l}\text { Uranium, } \\
(\mu \mathrm{g} / \mathrm{g})\end{array}$ \\
\hline 330 & $06-11-91$ & 1445 & 170 & $<40$ & $<4$ & $<5$ & 0.17 & $<100$ \\
480 & $06-12-91$ & 1130 & 170 & $<40$ & $<4$ & $<5$ & 0.22 & $<100$ \\
500 & $06-12-91$ & 1320 & 170 & $<40$ & $<4$ & $<5$ & 0.23 & $<100$ \\
602 & $06-12-91$ & 1430 & 140 & $<40$ & $<4$ & $<5$ & 0.18 & $<100$
\end{tabular}

\begin{tabular}{lcccccc}
\hline $\begin{array}{l}\text { Site } \\
\text { num- } \\
\text { ber }^{1}\end{array}$ & Date & Time & $\begin{array}{l}\text { Vanadium, } \\
(\mu \mathrm{g} / \mathrm{g})\end{array}$ & $\begin{array}{l}\text { Yttrium, } \\
(\mu \mathrm{g} / \mathrm{g})\end{array}$ & $\begin{array}{l}\text { Ytterbium, } \\
(\mu \mathrm{g} / \mathrm{g})\end{array}$ & $\begin{array}{l}\text { Zinc, } \\
(\mu \mathrm{g} / \mathrm{g})\end{array}$ \\
\hline 330 & $06-11-91$ & 1445 & 46 & 8 & $<1$ & 59 \\
480 & $06-12-91$ & 1130 & 52 & 10 & $<1$ & 610 \\
500 & $06-12-91$ & 1320 & 57 & 12 & 1 & 210 \\
602 & $06-12-91$ & 1430 & 44 & 11 & $<1$ & 190 \\
\hline
\end{tabular}

${ }^{1}$ Site numbers are the last three digits of the stream-flow station numbers assigned by the U.S. Geological Survey (for example, site 330 refers to station number 12090330). 
Table A6.--Organic-compound data for the Clover Creek Basin, 1991-92

$[\mu \mathrm{g} / \mathrm{L}$, micrograms per liter; <, less than; --, no data]

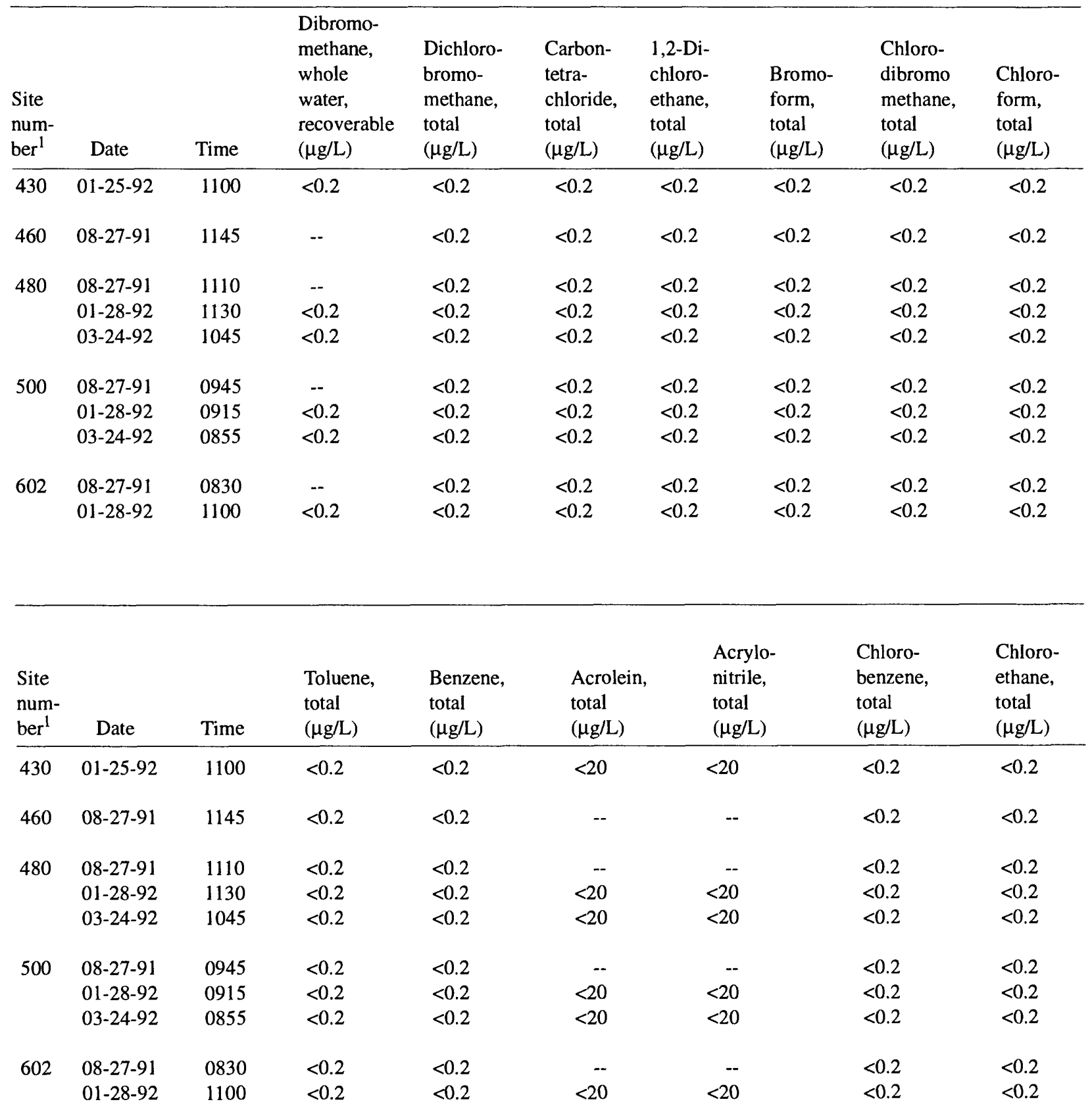


Table A6.--Organic-compound data for the Clover Creek Basin, 1991-92--Continued

\begin{tabular}{|c|c|c|c|c|c|c|c|c|}
\hline $\begin{array}{l}\text { Site } \\
\text { num- } \\
\text { ber }^{1}\end{array}$ & Date & Time & $\begin{array}{l}\text { Ethyl- } \\
\text { benzene, } \\
\text { total } \\
(\mu \mathrm{g} / \mathrm{L})\end{array}$ & $\begin{array}{l}\text { Methyl- } \\
\text { bromide, } \\
\text { total } \\
(\mu \mathrm{g} / \mathrm{L})\end{array}$ & $\begin{array}{l}\text { Methyl- } \\
\text { chloride, } \\
\text { total } \\
(\mu \mathrm{g} / \mathrm{L})\end{array}$ & $\begin{array}{l}\text { Methyl- } \\
\text { ene } \\
\text { chloride, } \\
\text { total } \\
(\mu \mathrm{g} / \mathrm{L})\end{array}$ & $\begin{array}{l}\text { Tetra- } \\
\text { chloro- } \\
\text { ethylene, } \\
\text { total } \\
(\mu \mathrm{g} / \mathrm{L})\end{array}$ & $\begin{array}{l}\text { Tri- } \\
\text { chloro- } \\
\text { fluoro- } \\
\text { methane, } \\
\text { total } \\
(\mu \mathrm{g} / \mathrm{L})\end{array}$ \\
\hline 430 & $01-25-92$ & 1100 & $<0.2$ & $<0.2$ & $<0.2$ & $<0.2$ & $<0.2$ & $<0.2$ \\
\hline 460 & $08-27-91$ & 1145 & $<0.2$ & $<0.2$ & $<0.2$ & $<0.2$ & $<0.2$ & $<0.2$ \\
\hline \multirow[t]{3}{*}{480} & $08-27-91$ & 1110 & $<0.2$ & $<0.2$ & $<0.2$ & $<0.2$ & $<0.2$ & $<0.2$ \\
\hline & $01-28-92$ & 1130 & $<0.2$ & $<0.2$ & $<0.2$ & $<0.2$ & $<0.2$ & $<0.2$ \\
\hline & $03-24-92$ & 1045 & $<0.2$ & $<0.2$ & $<0.2$ & $<0.2$ & $<0.2$ & $<0.2$ \\
\hline \multirow[t]{3}{*}{500} & $08-27-91$ & 0945 & $<0.2$ & $<0.2$ & $<0.2$ & $<0.2$ & $<0.2$ & $<0.2$ \\
\hline & $01-28-92$ & 0915 & $<0.2$ & $<0.2$ & $<0.2$ & $<0.2$ & $<0.2$ & $<0.2$ \\
\hline & $03-24-92$ & 0855 & $<0.2$ & $<0.2$ & $<0.2$ & $<0.2$ & $<0.2$ & $<0.2$ \\
\hline \multirow[t]{2}{*}{602} & $08-27-91$ & 0830 & $<0.2$ & $<0.2$ & $<0.2$ & $<0.2$ & $<0.2$ & $<0.2$ \\
\hline & $01-28-92$ & 1100 & $<0.2$ & $<0.2$ & $<0.2$ & $<0.2$ & $<0.2$ & $<0.2$ \\
\hline
\end{tabular}

\begin{tabular}{|c|c|c|c|c|c|c|c|c|}
\hline $\begin{array}{l}\text { Site } \\
\text { num- } \\
\text { ber }^{1}\end{array}$ & Date & Time & $\begin{array}{l}\text { 1,1-Di- } \\
\text { chloro- } \\
\text { ethane, } \\
\text { total } \\
(\mu \mathrm{g} / \mathrm{L})\end{array}$ & $\begin{array}{l}\text { 1,1-Di- } \\
\text { chloro- } \\
\text { ethylene, } \\
\text { total } \\
(\mu \mathrm{g} / \mathrm{L})\end{array}$ & $\begin{array}{l}1,1,1- \\
\text { Tri- } \\
\text { chloro- } \\
\text { ethane, } \\
\text { total } \\
(\mu \mathrm{g} / \mathrm{L})\end{array}$ & $\begin{array}{l}1,1,2- \\
\text { Tri- } \\
\text { chloro- } \\
\text { ethane, } \\
\text { total } \\
(\mu \mathrm{g} / \mathrm{L})\end{array}$ & $\begin{array}{l}1,1,2,2- \\
\text { Tetra- } \\
\text { chloro- } \\
\text { ethane, } \\
\text { unfiltered } \\
\text { water, } \\
\text { recoverable } \\
(\mu \mathrm{g} / \mathrm{L})\end{array}$ & $\begin{array}{l}o \text {-Chloro- } \\
\text { benzene, } \\
\text { unfiltered } \\
\text { water, } \\
\text { recoverable } \\
(\mu \mathrm{g} / \mathrm{L})\end{array}$ \\
\hline 430 & $01-25-92$ & 1100 & $<0.2$ & $<0.2$ & $<0.2$ & $<0.2$ & $<0.2$ & $<0.2$ \\
\hline 460 & $08-27-91$ & 1145 & $<0.2$ & $<0.2$ & $<0.2$ & $<0.2$ & $<0.2$ & $<0.2$ \\
\hline \multirow[t]{3}{*}{480} & $08-27-91$ & 1110 & $<0.2$ & $<0.2$ & $<0.2$ & $<0.2$ & $<0.2$ & $<0.2$ \\
\hline & $01-28-92$ & 1130 & $<0.2$ & $<0.2$ & $<0.2$ & $<0.2$ & $<0.2$ & $<0.2$ \\
\hline & $03-24-92$ & 1045 & $<0.2$ & $<0.2$ & $<0.2$ & $<0.2$ & $<0.2$ & $<0.2$ \\
\hline \multirow[t]{3}{*}{500} & $08-27-91$ & 0945 & $<0.2$ & $<0.2$ & $<0.2$ & $<0.2$ & $<0.2$ & $<0.2$ \\
\hline & $01-28-92$ & 0915 & $<0.2$ & $<0.2$ & $<0.2$ & $<0.2$ & $<0.2$ & $<0.2$ \\
\hline & $03-24-92$ & 0855 & $<0.2$ & $<0.2$ & $<0.2$ & $<0.2$ & $<0.2$ & $<0.2$ \\
\hline \multirow[t]{2}{*}{602} & $08-27-91$ & 0830 & $<0.2$ & $<0.2$ & $<0.2$ & $<0.2$ & $<0.2$ & $<0.2$ \\
\hline & $01-28-92$ & 1100 & $<0.2$ & $<0.2$ & $<0.2$ & $<0.2$ & $<0.2$ & $<0.2$ \\
\hline
\end{tabular}


Table A6.--Organic-compound data for the Clover Creek Basin, 1991-92--Continued

\begin{tabular}{|c|c|c|c|c|c|c|c|c|}
\hline $\begin{array}{l}\text { Site } \\
\text { num- } \\
\text { ber }\end{array}$ & Date & Time & $\begin{array}{l}\text { 1,2,-Di- } \\
\text { chloro- } \\
\text { propane, } \\
\text { total } \\
(\mu \mathrm{g} / \mathrm{L})\end{array}$ & $\begin{array}{l}1,2- \\
\text { trans- } \\
\text { Dichloro } \\
\text { ethene, } \\
\text { total } \\
(\mu \mathrm{g} / \mathrm{L})\end{array}$ & $\begin{array}{l}1,2,3- \\
\text { Trichloro- } \\
\text { benzene, } \\
\text { whole } \\
\text { water, } \\
\text { recoerable } \\
(\mu \mathrm{g} / \mathrm{L})\end{array}$ & $\begin{array}{l}1,3,-\mathrm{Di}- \\
\text { chloro- } \\
\text { propene, } \\
\text { total } \\
(\mu \mathrm{g} / \mathrm{L})\end{array}$ & $\begin{array}{l}\text { 1,3-Di- } \\
\text { chloro- } \\
\text { benzene, } \\
\text { unfiltered } \\
\text { water, } \\
\text { recoverable } \\
(\mu \mathrm{g} / \mathrm{L})\end{array}$ & $\begin{array}{l}\text { 1,4-Di- } \\
\text { chloro- } \\
\text { benzene, } \\
\text { unfiltered } \\
\text { water, } \\
\text { recoverable } \\
(\mu \mathrm{g} / \mathrm{L})\end{array}$ \\
\hline 430 & $01-25-92$ & 1100 & $<0.2$ & $<0.2$ & $<0.2$ & -- & $<0.2$ & $<0.2$ \\
\hline 460 & $08-27-91$ & 1145 & $<0.2$ & $<0.2$ & -- & $<0.2$ & $<0.2$ & $<0.2$ \\
\hline \multirow[t]{3}{*}{480} & $08-27-91$ & 1110 & $<0.2$ & $<0.2$ & -- & $<0.2$ & $<0.2$ & $<0.2$ \\
\hline & $01-28-92$ & 1130 & $<0.2$ & $<0.2$ & $<0.2$ & -- & $<0.2$ & $<0.2$ \\
\hline & $03-24-92$ & 1045 & $<0.2$ & $<0.2$ & $<0.2$ & -- & $<0.2$ & $<0.2$ \\
\hline \multirow[t]{3}{*}{500} & $08-27-91$ & 0945 & $<0.2$ & $<0.2$ & -- & $<0.2$ & $<0.2$ & $<0.2$ \\
\hline & $01-28-92$ & 0915 & $<0.2$ & $<0.2$ & $<0.2$ & -. & $<0.2$ & $<0.2$ \\
\hline & $03-24-92$ & 0855 & $<0.2$ & $<0.2$ & $<0.2$ & -- & $<0.2$ & $<0.2$ \\
\hline \multirow[t]{2}{*}{602} & $08-27-91$ & 0830 & $<0.2$ & $<0.2$ & -- & $<0.2$ & $<0.2$ & $<0.2$ \\
\hline & $01-28-92$ & 1100 & $<0.2$ & $<0.2$ & $<0.2$ & -- & $<0.2$ & $<0.2$ \\
\hline
\end{tabular}

\begin{tabular}{|c|c|c|c|c|c|c|c|c|}
\hline $\begin{array}{l}\text { Site } \\
\text { num- } \\
\text { ber }^{1}\end{array}$ & Date & Time & $\begin{array}{l}\text { 2- } \\
\text { chloro- } \\
\text { ethyl- } \\
\text { vinyl- } \\
\text { ether, } \\
\text { total } \\
(\mu \mathrm{g} / \mathrm{L})\end{array}$ & $\begin{array}{l}\text { Di- } \\
\text { chloro- } \\
\text { difluoro- } \\
\text { methane, } \\
\text { total } \\
(\mu \mathrm{g} / \mathrm{L})\end{array}$ & $\begin{array}{l}\text { Napth- } \\
\text { alene, } \\
\text { total } \\
(\mu \mathrm{g} / \mathrm{L})\end{array}$ & $\begin{array}{l}1,3- \\
\text { trans- } \\
\text { Dichloro- } \\
\text { propene, } \\
\text { total } \\
(\mu \mathrm{g} / \mathrm{L})\end{array}$ & $\begin{array}{l}1,3- \\
\text { cis-Di } \\
\text { chloro- } \\
\text { propene, } \\
\text { total } \\
(\mu \mathrm{g} / \mathrm{L})\end{array}$ & $\begin{array}{l}\text { Vinyl } \\
\text { chlo- } \\
\text { ride, } \\
\text { total } \\
(\mu \mathrm{g} / \mathrm{L})\end{array}$ \\
\hline 430 & $01-25-92$ & 1100 & $<1$ & $<0.2$ & $<0.2$ & $<0.2$ & $<0.2$ & $<0.2$ \\
\hline 460 & $08-27-91$ & 1145 & $<0.2$ & $<0.2$ & -- & $<0.2$ & $<0.2$ & $<0.2$ \\
\hline 480 & $\begin{array}{l}08-27-91 \\
01-28-92 \\
03-24-92\end{array}$ & $\begin{array}{l}1110 \\
1130 \\
1045\end{array}$ & $\begin{array}{l}<0.2 \\
<1 \\
<1\end{array}$ & $\begin{array}{l}<0.2 \\
<0.2 \\
<0.2\end{array}$ & $\begin{array}{l}-- \\
<0.2 \\
<0.2\end{array}$ & $\begin{array}{l}<0.2 \\
<0.2 \\
<0.2\end{array}$ & $\begin{array}{l}<0.2 \\
<0.2 \\
<0.2\end{array}$ & $\begin{array}{l}<0.2 \\
<0.2 \\
<0.2\end{array}$ \\
\hline 500 & $\begin{array}{l}08-27-91 \\
01-28-92 \\
03-24-92\end{array}$ & $\begin{array}{l}0945 \\
0915 \\
0855\end{array}$ & $\begin{array}{l}<0.2 \\
<1 \\
<1\end{array}$ & $\begin{array}{l}<0.2 \\
<0.2 \\
<0.2\end{array}$ & $\begin{array}{l}-- \\
<0.2 \\
<0.2\end{array}$ & $\begin{array}{l}<0.2 \\
<0.2 \\
<0.2\end{array}$ & $\begin{array}{l}<0.2 \\
<0.2 \\
<0.2\end{array}$ & $\begin{array}{l}<0.2 \\
<0.2 \\
<0.2\end{array}$ \\
\hline 602 & $\begin{array}{l}08-27-91 \\
01-28-92\end{array}$ & $\begin{array}{l}0830 \\
1100\end{array}$ & $\begin{array}{l}<0.2 \\
<1\end{array}$ & $\begin{array}{l}<0.2 \\
<0.2\end{array}$ & $\begin{array}{l}-- \\
<0.2\end{array}$ & $\begin{array}{l}<0.2 \\
<0.2\end{array}$ & $\begin{array}{l}<0.2 \\
<0.2\end{array}$ & $\begin{array}{l}<0.2 \\
<0.2\end{array}$ \\
\hline
\end{tabular}


Table A6.--Organic-compound data for the Clover Creek Basin, 1991-92--Continued

\begin{tabular}{|c|c|c|c|c|c|c|c|c|}
\hline $\begin{array}{l}\text { Site } \\
\text { num- } \\
\text { ber }{ }^{1}\end{array}$ & Date & Time & $\begin{array}{l}\text { Tri- } \\
\text { chloro- } \\
\text { ethyl- } \\
\text { ene, } \\
\text { total } \\
(\mu \mathrm{g} / \mathrm{L})\end{array}$ & $\begin{array}{l}\text { Hexa- } \\
\text { chloro- } \\
\text { but- } \\
\text { adiene, } \\
\text { total } \\
(\mu \mathrm{g} / \mathrm{L})\end{array}$ & $\begin{array}{l}1,2- \\
\text { cis-Di- } \\
\text { chloro- } \\
\text { ethene, } \\
\text { total } \\
(\mu \mathrm{g} / \mathrm{L})\end{array}$ & $\begin{array}{l}\text { Styrene, } \\
\text { total } \\
(\mu \mathrm{g} / \mathrm{L})\end{array}$ & $\begin{array}{l}\text { 1,1-Di- } \\
\text { chloro- } \\
\text { propene, } \\
\text { whole } \\
\text { water, } \\
\text { total } \\
(\mu \mathrm{g} / \mathrm{L})\end{array}$ & $\begin{array}{l}2,2-\mathrm{Di}- \\
\text { chloro- } \\
\text { propane, } \\
\text { whole } \\
\text { water, } \\
\text { total } \\
(\mu \mathrm{g} / \mathrm{L})\end{array}$ \\
\hline 430 & $01-25-92$ & 1100 & $<0.2$ & $<0.2$ & $<0.2$ & $<0.2$ & $<0.2$ & $<0.2$ \\
\hline 460 & $08-27-91$ & 1145 & $<0.2$ & -- & -- & $<0.2$ & -- & - \\
\hline \multirow[t]{3}{*}{480} & $08-27-91$ & 1110 & $<0.2$ & -- & -- & $<0.2$ & -- & -- \\
\hline & $01-28-92$ & 1130 & $<0.2$ & $<0.2$ & $<0.2$ & $<0.2$ & $<0.2$ & $<0.2$ \\
\hline & $03-24-92$ & 1045 & $<0.2$ & $<0.2$ & $<0.2$ & $<0.2$ & $<0.2$ & $<0.2$ \\
\hline \multirow[t]{3}{*}{500} & $08-27-91$ & 0945 & $<0.2$ & - & -- & $<0.2$ & -- & -- \\
\hline & $01-28-92$ & 0915 & $<0.2$ & $<0.2$ & $<0.2$ & $<0.2$ & $<0.2$ & $<0.2$ \\
\hline & $03-24-92$ & 0855 & $<0.2$ & $<0.2$ & $<0.2$ & $<0.2$ & $<0.2$ & $<0.2$ \\
\hline \multirow[t]{2}{*}{602} & $08-27-91$ & 0830 & $<0.2$ & -- & -- & $<0.2$ & -- & -- \\
\hline & $01-28-92$ & 1100 & $<0.2$ & $<0.2$ & $<0.2$ & $<0.2$ & $<0.2$ & $<0.2$ \\
\hline
\end{tabular}

\begin{tabular}{|c|c|c|c|c|c|c|c|c|}
\hline $\begin{array}{l}\text { Site } \\
\text { num- } \\
\text { ber }^{1}\end{array}$ & Date & Time & $\begin{array}{l}\text { 1,3-Di- } \\
\text { chloro- } \\
\text { propane, } \\
\text { whole } \\
\text { water, } \\
\text { total } \\
(\mu \mathrm{g} / \mathrm{L})\end{array}$ & $\begin{array}{l}\text { Pseudo- } \\
\text { cumene, } \\
\text { unfiltered } \\
\text { water, } \\
\text { recoverable } \\
(\mu \mathrm{g} / \mathrm{L})\end{array}$ & $\begin{array}{l}\text { Iso- } \\
\text { propyl- } \\
\text { benzene, } \\
\text { whole } \\
\text { water, } \\
\text { recoverable } \\
(\mu \mathrm{g} / \mathrm{L})\end{array}$ & $\begin{array}{l}n \text {-Propyl- } \\
\text { benzene, } \\
\text { unfiltered } \\
\text { water, } \\
\text { recoverable } \\
(\mu \mathrm{g} / \mathrm{L})\end{array}$ & $\begin{array}{l}\text { Mesit- } \\
\text { ylene, } \\
\text { unfiltered } \\
\text { water, } \\
\text { recoverable } \\
(\mu \mathrm{g} / \mathrm{L})\end{array}$ & $\begin{array}{l}o- \\
\text { Chloro- } \\
\text { toluene, } \\
\text { whole } \\
\text { water, } \\
\text { total } \\
(\mu \mathrm{g} / \mathrm{L})\end{array}$ \\
\hline 430 & $01-25-92$ & 1100 & $<0.2$ & -- & -- & -- & -- & $<0.2$ \\
\hline 460 & $08-27-91$ & 1145 & - & -- & -- & -- & -- & -- \\
\hline \multirow[t]{3}{*}{480} & $08-27-91$ & 1110 & -- & -- & -- & -- & -- & -- \\
\hline & $01-28-92$ & 1130 & $<0.2$ & -- & -- & -- & -- & $<0.2$ \\
\hline & $03-24-92$ & 1045 & $<0.2$ & $<0.2$ & $<0.2$ & $<0.2$ & $<0.2$ & $<0.2$ \\
\hline \multirow{3}{*}{500} & $08-27-91$ & 0945 & -- & -- & -- & -- & -- & -- \\
\hline & $01-28-92$ & 0915 & $<0.2$ & -- & -- & -- & -- & $<0.2$ \\
\hline & 03-24-92 & 0855 & $<0.2$ & $<0.2$ & $<0.2$ & $<0.2$ & $<0.2$ & $<0.2$ \\
\hline \multirow[t]{2}{*}{602} & $08-27-91$ & 0830 & -- & -- & -- & -- & -- & -- \\
\hline & $01-28-92$ & 1100 & $<0.2$ & -- & -- & -- & -- & $<0.2$ \\
\hline
\end{tabular}


Table A6.--Organic-compound data for the Clover Creek Basin, 1991-92--Continued

\begin{tabular}{|c|c|c|c|c|c|c|c|c|}
\hline $\begin{array}{l}\text { Site } \\
\text { num- } \\
\text { ber }^{1}\end{array}$ & Date & Time & $\begin{array}{l}p \text {-Chloro- } \\
\text { toluene, } \\
\text { unfiltered } \\
\text { water, } \\
\text { recoverable } \\
(\mu \mathrm{g} / \mathrm{L})\end{array}$ & $\begin{array}{l}n \text {-Butyl- } \\
\text { benzene, } \\
\text { unfiltered } \\
\text { water, } \\
\text { recoverable } \\
(\mu \mathrm{g} / \mathrm{L})\end{array}$ & $\begin{array}{l}\text { sec- } \\
\text { Butyl- } \\
\text { benzene, } \\
\text { unfiltered } \\
\text { water, } \\
\text { recoverable } \\
(\mu \mathrm{g} / \mathrm{L})\end{array}$ & $\begin{array}{l}\text { tert- } \\
\text { Butyl- } \\
\text { benzene, } \\
\text { unfiltered } \\
\text { water, } \\
\text { recoverable } \\
(\mu \mathrm{g} / \mathrm{L})\end{array}$ & $\begin{array}{l}p \text {-Iso- } \\
\text { propyl- } \\
\text { toluene, } \\
\text { whole } \\
\text { water, } \\
\text { recoverable } \\
(\mu \mathrm{g} / \mathrm{L})\end{array}$ & $\begin{array}{l}\text { 1,2,3-Tri- } \\
\text { chloro- } \\
\text { propane } \\
\text { whole } \\
\text { water, } \\
\text { total } \\
(\mu \mathrm{g} / \mathrm{L})\end{array}$ \\
\hline 430 & $01-25-92$ & 1100 & $<0.2$ & - & -- & -- & -- & $<0.2$ \\
\hline 460 & $08-27-91$ & 1145 & -- & -- & -- & -- & -- & -- \\
\hline \multirow[t]{3}{*}{480} & $08-27-91$ & 1110 & -- & -- & -- & -- & -- & -- \\
\hline & $01-28-92$ & 1130 & $<0.2$ & -- & -- & -- & -- & $<0.2$ \\
\hline & $03-24-92$ & 1045 & $<0.2$ & $<0.2$ & $<0.2$ & $<0.2$ & $<0.2$ & $<0.2$ \\
\hline \multirow[t]{3}{*}{500} & $08-27-91$ & 0945 & -- & -- & -- & -- & -- & -- \\
\hline & $01-28-92$ & 0915 & $<0.2$ & -- & -. & .- & -- & $<0.2$ \\
\hline & 03-24-92 & 0855 & $<0.2$ & $<0.2$ & $<0.2$ & $<0.2$ & $<0.2$ & $<0.2$ \\
\hline \multirow[t]{2}{*}{602} & $08-27-91$ & 0830 & -- & -- & -- & -- & -- & -- \\
\hline & $01-28-92$ & 1100 & $<0.2$ & -- & -- & -- & -- & $<0.2$ \\
\hline
\end{tabular}

\begin{tabular}{|c|c|c|c|c|c|c|c|c|}
\hline $\begin{array}{l}\text { Site } \\
\text { num- } \\
\text { ber }^{1}\end{array}$ & Date & Time & $\begin{array}{l}1,1,2,2- \\
\text { Tetra- } \\
\text { chloro- } \\
\text { ethane, } \\
\text { unfiltered } \\
\text { water, } \\
\text { recoverable } \\
(\mu \mathrm{g} / \mathrm{L})\end{array}$ & $\begin{array}{l}1,2,4- \\
\text { Tri- } \\
\text { chloro- } \\
\text { benzene, } \\
\text { whole } \\
\text { water, } \\
\text { recoverable } \\
(\mu \mathrm{g} / \mathrm{L})\end{array}$ & $\begin{array}{l}1,2- \\
\text { Dibromo- } \\
\text { ethane, } \\
\text { whole } \\
\text { water, } \\
\text { total } \\
(\mu \mathrm{g} / \mathrm{L})\end{array}$ & $\begin{array}{l}\text { Xlene, } \\
\text { unfiltered } \\
\text { water, } \\
\text { recoverable } \\
(\mu \mathrm{g} / \mathrm{L})\end{array}$ & $\begin{array}{l}\text { Bromo- } \\
\text { benzene, } \\
\text { whole } \\
\text { water, } \\
\text { total } \\
(\mu \mathrm{g} / \mathrm{L})\end{array}$ & $\begin{array}{l}\text { Dibromo- } \\
\text { chloro- } \\
\text { propane, } \\
\text { whole } \\
\text { water, } \\
\text { total } \\
\text { recoverable } \\
(\mu \mathrm{g} / \mathrm{L})\end{array}$ \\
\hline 430 & $01-25-92$ & 1100 & $<0.2$ & -- & $<0.2$ & $<0.2$ & $<0.2$ & $<1$ \\
\hline 460 & $08-27-91$ & 1145 & -- & -- & $<0.2$ & $<0.2$ & -- & -- \\
\hline \multirow[t]{3}{*}{480} & $08-27-91$ & 1110 & -- & -- & $<0.2$ & $<0.2$ & -- & -- \\
\hline & $01-28-92$ & 1130 & $<0.2$ & -- & $<0.2$ & $<0.2$ & $<0.2$ & $<1$ \\
\hline & $03-24-92$ & 1045 & $<0.2$ & $<0.2$ & $<0.2$ & $<0.2$ & $<0.2$ & $<1$ \\
\hline \multirow[t]{3}{*}{500} & $08-27-91$ & 0945 & -- & -. & $<0.2$ & $<0.2$ & -- & - \\
\hline & $01-28-92$ & 0915 & $<0.2$ & -- & $<0.2$ & $<0.2$ & $<0.2$ & $<1$ \\
\hline & $03-24-92$ & 0855 & $<0.2$ & $<0.2$ & $<0.2$ & $<0.2$ & $<0.2$ & $<1$ \\
\hline \multirow[t]{2}{*}{602} & $08-27-91$ & 0830 & -- & -- & $<0.2$ & $<0.2$ & -- & -- \\
\hline & $01-28-92$ & 1100 & $<0.2$ & -- & $<0.2$ & $<0.2$ & $<0.2$ & $<1$ \\
\hline
\end{tabular}

${ }^{1}$ Site numbers are the last three digits of the eight-digit stream-flow station numbers assigned by the U.S. Geological Survey (for example, site 330 refers to station number 12090330). 
Appendix B.--Quality-Assurance Data 


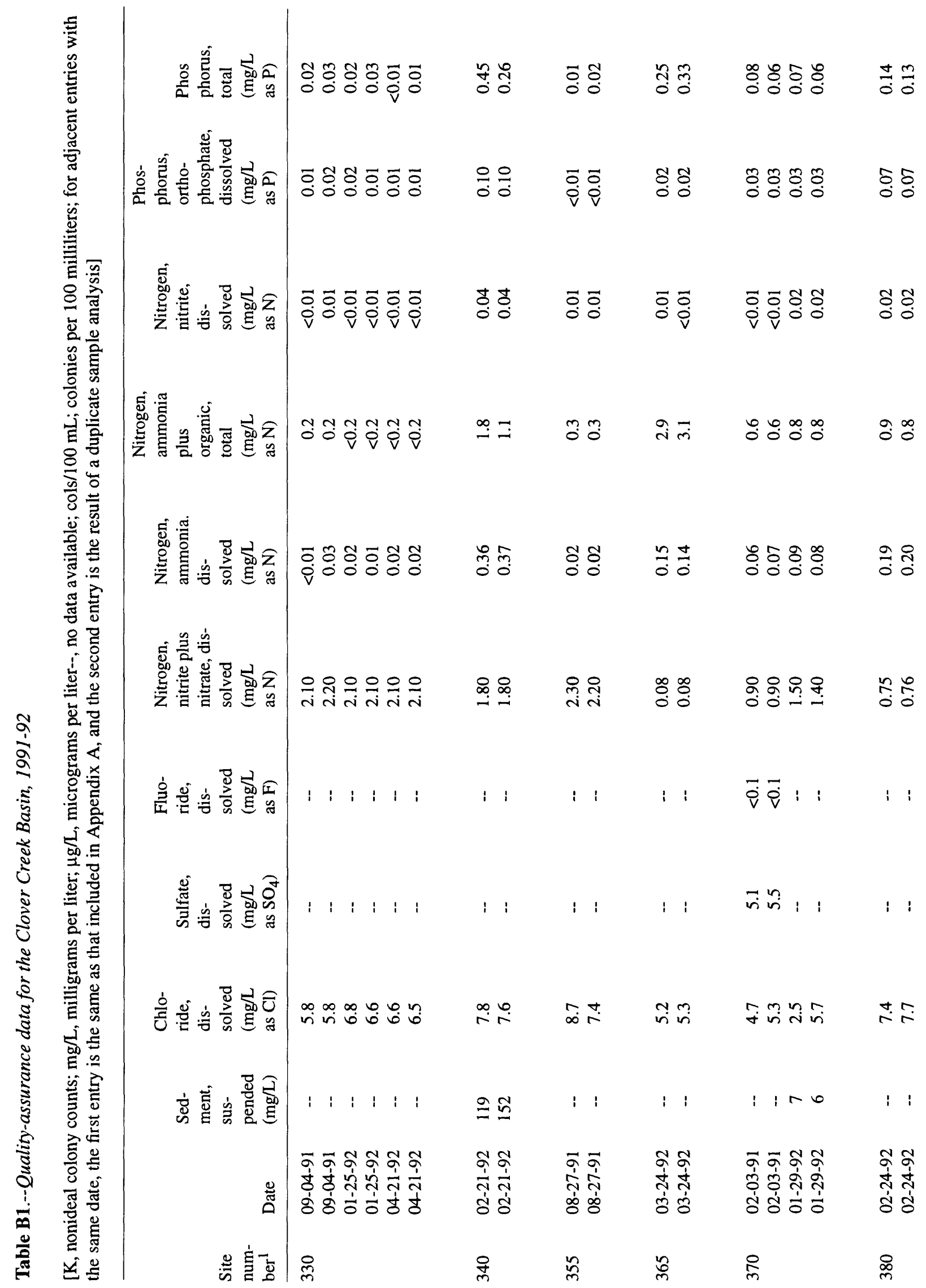




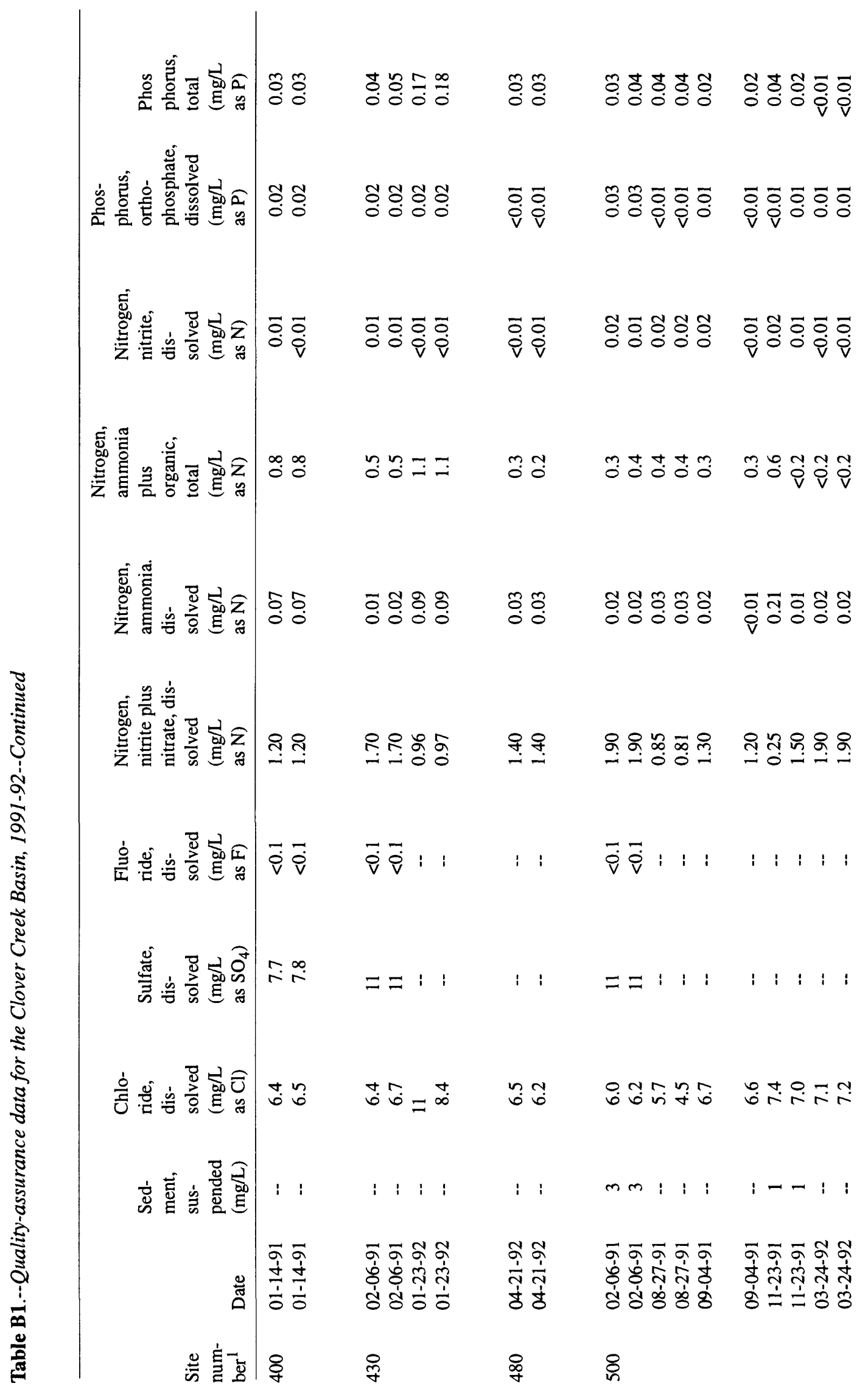




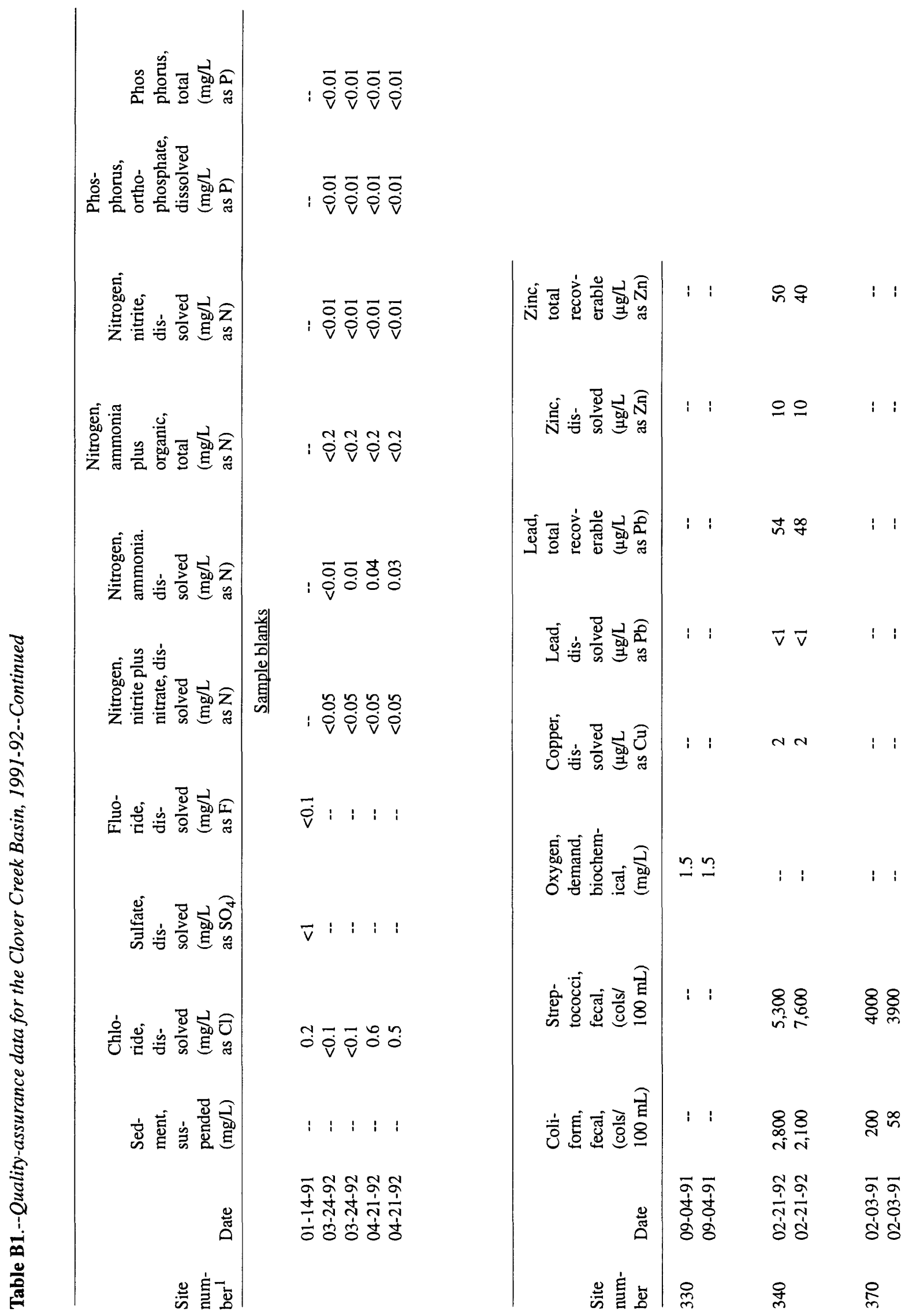




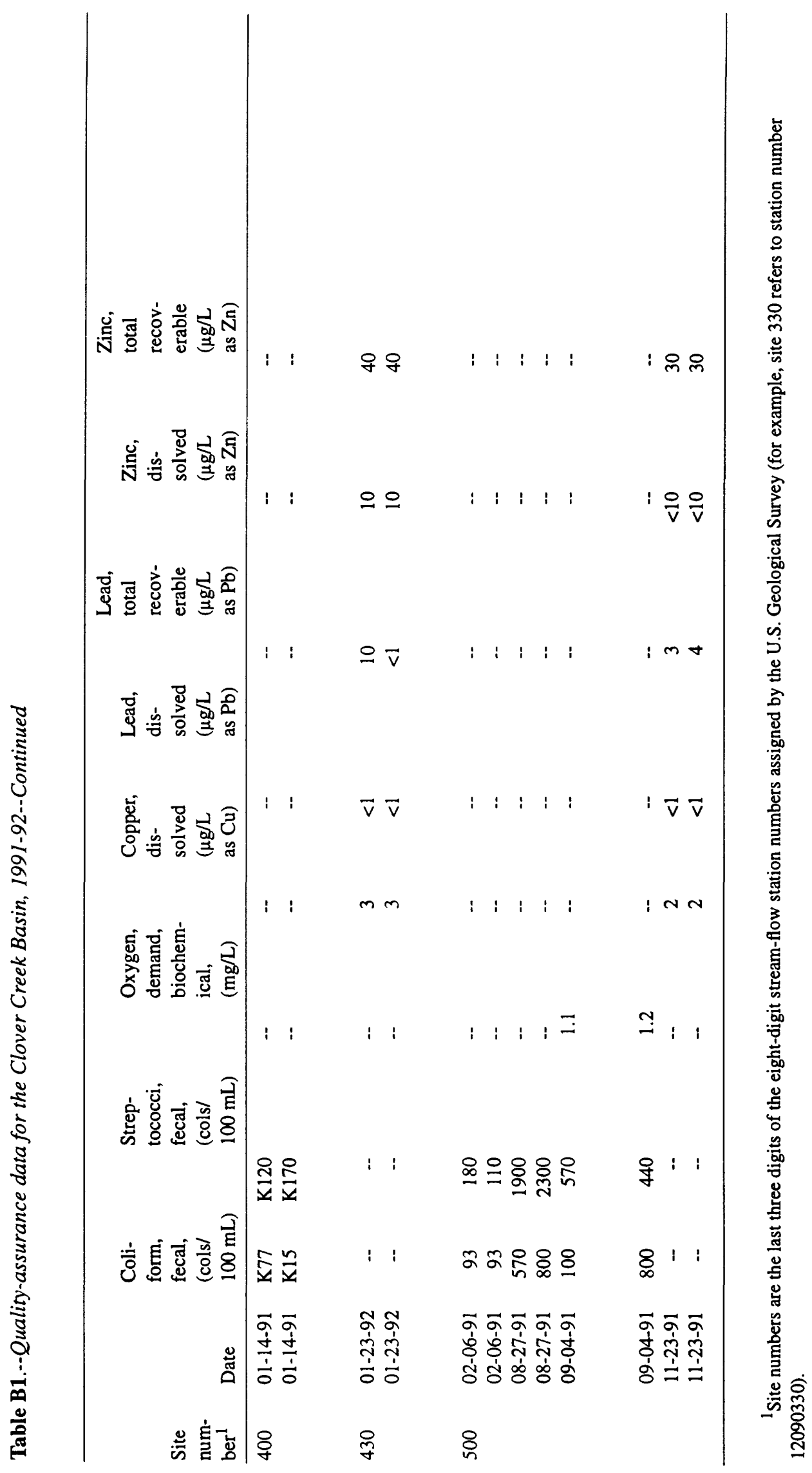

